PAUL AND ISAIAH'S SERVANTS : PAUL'S THEOLOGICAL READING OF ISAIAH 40-66 IN 2 CORINTHIANS 5:14 - 6:10

Mark Salem Gignilliat

A Thesis Submitted for the Degree of PhD at the

University of St Andrews

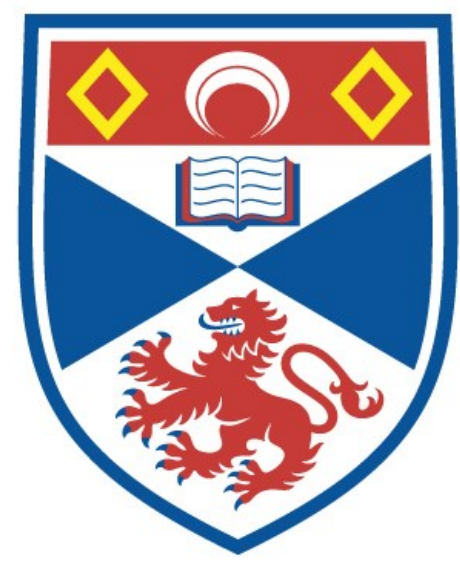

2005

Full metadata for this item is available in

St Andrews Research Repository

at:

http://research-repository.st-andrews.ac.uk/

Please use this identifier to cite or link to this item:

http://hdl.handle.net/10023/1345.5

This item is protected by original copyright 
Paul and Isaiah's Servants:

Paul's Theological Reading of Isaiah 40-66 in 2 Corinthians 5:14-6:10

By

Mark Salem Gignilliat

Dissertation Submitted

To the University of Saint Andrews

In Fulfillment of the Requirements

For the Degree

Doctor of Philosophy

April 12, 2005 
All rights reserved

INFORMATION TO ALL USERS

The quality of this reproduction is dependent upon the quality of the copy submitted.

In the unlikely event that the author did not send a complete manuscript and there are missing pages, these will be noted. Also, if material had to be removed, a note will indicate the deletion.

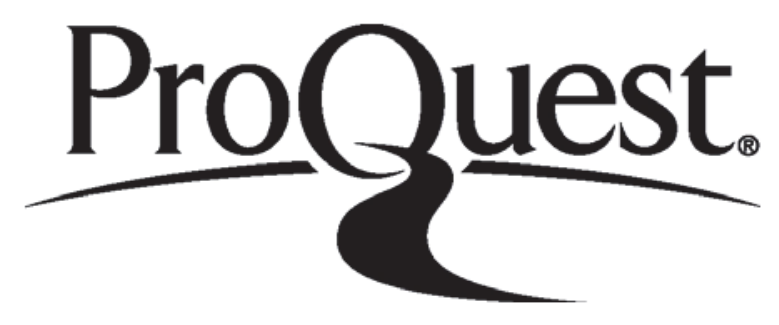

ProQuest 10166831

Published by ProQuest LLC (2017). Copyright of the Dissertation is held by the Author.

All rights reserved.

This work is protected against unauthorized copying under Title 17, United States Code Microform Edition (C) ProQuest LLC.

ProQuest LLC.

789 East Eisenhower Parkway

P.O. Box 1346

Ann Arbor, Ml $48106-1346$ 
Th E910 


\section{Declaration Page}

I, . hereby certify that this thesis, which is approximately $P\{, m$ ? 1 . words in length, has been written by me, that it is the record of work carried out by me and that it has not been submitted in any previous application for a higher degree.

date .Apail..12.2.2015

signature of candidate

I was admitted as a research student in I?.?.:. [month, year] and as a candidate for the degree of .Ph.P........ in $4 . / 53 \ldots .$. [month, year]; the higher study for which this is a record was carried out in the University of St Andrews between $2 \times \div 2 . .$. [year] and .2s....... [year].

date $A_{m i}+\ldots, ?, 2, * 5$ signature of candidate ...

I hereby certify that the candidate has fulfilled the conditions of the Resolution and Regulations appropriate for the degree of ............. in the University of St Andrews and that the candidate is qualified to submit this thesis in application for that degree.

date $26-04-05$ signature of supervisor...

In submitting this thesis to the University of St Andrews I understand that I am giving permission for it to be made available for use in accordance with the regulations of the University Library for the time being in force, subject to any copyright vested in the work not being affected thereby. I also understand that the title and abstract will be published, and that a copy of the work may be made and supplied to any bona fide library or research worker.

date Aps.l...?.2.2001 signature of candidate 


\section{Dissertation Abstract}

Paul's reading of the Old Testament continues to witness to the significance of reading the Old Testament Christianly. This dissertation argues that a theological approach to understanding Paul's appeal to and reading of the Old Testament, especially Isaiah, offers important insights into the ways in which Christians should read the Old Testament and a two-testament canon today. By way of example, this dissertation explores the ways in which Isaiah 40-66's canonical form presents the gospel in miniature with its movement from Israel to Servant to servants. It is subsequently argued that Paul follows this literary movement in his own theological reflection in 2 Corinthians 5:14-6:10. Jesus takes on the unique role and identity of the Servant of Isaiah 40-55, and Paul takes on the role of the servants of the Servant in Isaiah 53-66. From this exegetical exploration conclusions are drawn in the final chapter that seek to apply a term from the history of interpretation to Paul's reading, that is, the plain sense of Scripture. What does an appeal to plain sense broker? And does Paul's reading of the Old Testament look anything like a plain sense reading? The conclusion is, yes, Paul is reading the Old Testament in such a way that the literal sense and its figural potential and capacity are not divorced but are actually organically linked in what can be termed a plain sense reading. 


\section{Acknowledgments Page}

As is well known, a Ph.D. dissertation is not the product of an isolated scholar in a vacuum but is a project that takes place in a community where many, from differing perspectives, contribute to the final product. My heartfelt thanks are extended to North Hills Community Church of Greenville, SC who have offered encouragement and spiritual support along the way. I have not forgotten the prayers of the elders in that community. Financial support was offered to me from St. Matthew's Parish in Wheeling, West Virginia. Reverend Mark Seitz, the rector of St. Matthew's, was kind enough to affirm my journey in theological education. I am indeed humbled that a parish, whose parishioners I do not know, would offer the financial support they have. The Panacea Society also offered a scholarship for my final year of study. The Saint Andrew's Society of North Carolina underwrote a significant amount of my final year of research. I am very grateful for their support. Also, my good friend Frankie Byrd supported me financially and personally. My doctoral supervisors, Professor Christopher Seitz and Dr. Bruce Longenecker, both offered in their unique ways invaluable insight and leadership in the research and writing of this dissertation. You will often hear horror stories from Ph.D. candidates who have had an awful experience with their doctoral supervisors. I not only had one good supervisor; I had two. The impression these two have made on my thought and vision for theological research and teaching is inestimable. Also, the community of scholars and peers at St. Andrews provided an environment pregnant with discussion, encouragement, and hope for something other and greater in biblical studies and theological discourse. Special thanks should be given to Professor Richard Bauckham, Dr. Nathan MacDonald, Dr. Mark Elliott, and Dr. Oliver Crisp as well as my peers from the CTRG, Jonathan Pennington, Darian Lockett, Steven Mason, Tim Gombis, Daniel Gurtner, Mickey Klink, and honorary member Don Collett. I made a special aim of rubbing shoulders with the theologians who were studying at St. Andrews. My closest theological interlocutors and friends were Tee Gatewood, Stuart Noble, Ross Wright, Steven Prokopchuk, Trygve Johnson, Matt Jenson, and Cindy Burris. These all with their own special gifts and erudition contributed to a lively and engaging theological atmosphere at St. Andrews. I am the better for knowing them. Besides my wife, my parents are my closest friends on this earth. They have always encouraged me to pursue those things that seem unthinkable and costly. Not only have they supported my wife and me financially; they have been our biggest cheerleaders from the side. Bill and Martha Gignilliat have their fingerprints all over this project (even if they don't understand it!). Lastly, what does one say to his lover and best friend? Naomi, you have sacrificed so much for my dreams. I am only half a man without you and am deeply stamped by the journey we have taken together. This dissertation is dedicated to you. I gave birth to this monograph, but you gave birth to our son, William Salem. As is usually the case, your work is much finer than mine. 


\section{Table of Contents}

Chapter 1 - Paul, the Old Testament, and Theological Reading: Recent Interpretation and a Search for a Theological Approach

1. Introduction.

2. A Question of Methodology: Locating the OT in Paul's Epistles

3. Recent Approaches

3.a. Damaging Alteration.

3.b. Jewish Parallels-Midrash-Pesher.

3.b.i. Midrash.

3.b.ii. Pesher.

3.c. Citation Mechanics and Altered Vorlage.

3.d. Four Central Themes

3.e. Ecclesiastical Hermeneutic.

4. Paul's Sui Generis Character of OT Reading.

5. A Canonical Approach to Paul and the OT

6. Conclusion

Chapter 2-Placing the Exegetical/Theological Argument of 2 Corinthians 5:14-6:10

1. Introduction.

2. Paul's Main Theme in 2 Corinthians

3. Paul's Warrant for Suffering.

3.a. Scripture in 2 Corinthians 3

4. The Background of 2 Corinthians 5:11-7:1 in Recent Discussion

4.a. Questions Pertaining to Beale and Webb.

5. Paul and the Servant/Servants of Isaiah 40-55.

6. Aim of Exegetical Example.

Excurses: On Narrative Identity-Ricouer and Frei

1. Narrative Identity in Paul Ricouer.

2. Narrative Identity and Hans Frei.

3. Conclusion.

Chapter 3 - The Servant of Yahweh and 2 Corinthians 5:14-21:

Paul's Reading of the Redemptive Drama of Isaiah 40-66

1. 2 Corinthians 4:14-21 and its Literary Context

2. 2 Corinthians $6: 2$ as Hermeneutical Key.

3. The Redemptive Drama of Isaiah 40-55: A Larger Narrative Reading

3.a. The Larger Narrative of Isaiah 40-55.

3.a.i. The Servant's Central Role in the Isaianic Drama

3.a.ii. The "Servant Songs". 
3.a.ii.1. Isaiah $42: 1-4$

3.a.ii. 2. Isaiah 49:1-6

3.a.ii.3. Isaiah 50:4-9

3.a.ii.4. Isaiah 52:13-53:12

3.a.iii. The Servant's Narrative Identity

4. The Servant Jesus in 2 Corinthians 5:14-21

4.a. The One for the All

4.b. The New Eschatological Age

4.c. The Divine Initiative in the Act of Reconciliation and the

Servant/Chụist as Agent.

4.d. Reconciliation and the Forgiveness of Sins

5. Conclusion

Chapter 4-Paul: A Servant of the Servant

1. Introduction

2. Paul's Suffering and 2 Corinthians $6: 3-10$

3. The Servants to the Servant in Isaiah 54-66

3.a. Isaiah $56: 1-8$

3.b. The Servants in Isaiah 56:9-63:6

3.b.i. The First Main Section: 56:9-59:21

3.b.ii. The Second Main Section: 60:1-63:6

3.c. The Servants in Isaiah 63:7-66:22

3.c.i. Isaiah $63: 7-64: 12$

3.c.ii. The Servants in Isaiah 65-66.

3.d. The Servants' Narrative Identity...

4. Paul as a Servant of the Servant.

4.a. Paul as Diakonoi.

4.b. Paul as Herald.

4.c. Paul as Sufferer.

4.d. Paul as Righteous

4.e. Paul in the Eschatological Tension

5. Conclusion.

Chapter 5 - The Theological Implications of Paul's OT Reading

1. Introduction

2. A Theological Definition of Plain Sense

2.a. Peshat.

2.b. Brevard Childs on the Sensus Literalis

2.c. The Literal Sense and Figural Sense.

2.c.i. Typology and Allegory....

3.d. Towards a Theological Definition of the Plain Sense.

4. Conclusion 


\section{CHAPTER ONE}

\section{PAUL, THE OLD TESTAMENT, AND THEOLOGICAL READING: RECENT INTERPRETATION AND A SEARCH FOR A THEOLOGICAL APPROACH}

\section{Introduction}

Since the church's inception, the question of proper Old Testament reading has maintained a certain priority in the church's definition of itself. Von Campenhausen describes such a reality,

It is quite wrong to say that the Old Testament had no authority in its own right for the first Christians, and that it was taken over purely because people saw that it 'treated Christ' or pointed toward him. The situation was in fact quite the reverse. Christ is certainly vindicated to unbelievers out of the Scripture; but the converse necessity, to justify Scripture on the authority of Christ, is as yet nowhere even envisaged.

Though in time Marcion and others would raise questions regarding the OT, the validity of the OT during the church's inception and early development was not questioned. Its scriptural status was assumed. The pressing question for early Christians, therefore, was the proper understanding of Jesus Christ in light of that assumed Scripture. ${ }^{2}$ With the formation of the New Testament, biblical theology becomes a two-testament approach to the rightly ordered reception and explication of God's revelation in Jesus Christ. ${ }^{3}$ Both Old and New Testaments in their own discrete, yet perichoretic voices, speak of God's redemptive action in the cosmos with Jesus Christ as its defining center and subject matter.

The preceding comments are intended to set the backdrop for the dissertation at hand. It is stated at the outset that the question of Paul's OT usage is not being asked simply for reasons of historical background or interesting Wissenschaft. The question is theologically driven. Paul's OT reading, as contained within the Christian

\footnotetext{
${ }^{1}$ Hans von Campenhausen, The Formation of the Christian Bible (Philadelphia: Fortress, 1972), 63-64; see Henri de Lubac, "Spiritual Understanding," in Theological Interpretation of Scripture: Christian and Contemporary Readings (transl. L. O'Neill; ed. S. Fowl; Oxford: Blackwells Press, 1997), 8-9.

${ }^{2}$ Christopher Seitz, Word Without End: The Old Testament as Abiding Theological Witness (Grand Rapids: Eerdmans, 1998), 54.

${ }^{3}$ In this regard, see most especially Brevard Childs, Biblical Theology of the Old and New Testaments (Minneapolis: Fortress, 1992).
} 
canon, has something to say to the church today. With this stated, presuppositions and all, our attention in this present work will first and foremost deal with a particular exegetical question found in 2 Corinthians, namely, how is Paul deploying Isaiah 4066 in 2 Cor. 5:14-6:10. In what way does Isaiah 40-66 in its final canonical form and shape influence Paul's self-understanding and understanding of the significance of God's action in Christ. ${ }^{4}$ Our attention will focus on the dialectical relationship between Isaiah and Paul. Isaiah in its final canonical form informs our reading of Paul and Paul's eschatological situation informs our reading of Isaiah. Therefore, Isaiah's final form will be taken seriously and, equally so, Paul's eschatologically christocentric reading will be addressed. It is hoped that the exegetical section of this thesis will be found salient enough on its own so that even those who disagree with the theological conclusions in the final chapter will find some merit in the exegesis itself. Therefore, the influence of Isaiah's canonical message of redemption and its attendant key figures (the Servant and the servants of the Servant) on Paul's thought in 2 Cor 5:14-6:10 is task one of the current project and will carry the bulk of the written work. The theological significance of Paul's OT reading will be addressed in the final chapter as task two, taking the form of reflection on the significance of Paul's OT reading. ${ }^{5}$ Before turning to 2 Corinthians expressly, other matters of introduction will be rehearsed in the rest of the chapter at hand.

\section{A Question of Methodology: Locating the OT in Paul's Epistles}

Demonstrating the presence of the OT in Paul's letters, or in the NT broadly, is a daunting ordeal. Certainly, different exegetical temperaments are at work in the defining of this topic. Some scholars may likely find it difficult to work with the more subjective category of allusion or echo, preferring the more stable, objective category

\footnotetext{
${ }^{4}$ These would fall under Florian Wilk's categories of Christusbotschaft and Paul's selbstverstandnis (Florian Wilk, Die Bedeutung des Jesajabuches für Paulus [Göttingen: Vandenhoeck and Ruprecht, 1998]).Wilk gives attention to Isaiah in this passage but focuses primarily on 2 Cor 5:17 and 2 Cor 6:2. Little to no attention is given to the suffering Servant allusions in this text and the theme of the servants of the Servant is not observed at all. With this stated, these two categories of understanding are appropriate ones when dealing with Paul's reading of Isaiah. This work will expand on these themes with special attention given to two of the key figures in Isaiah's movement in chapters 40-66, namely, the Servant and the subsequent servants of the Servant.

"Of course these two "separate" tasks inform one another and are actually not separate at all. This author would be wary of Gabler's biblical theological ditch.
} 
of quotation. ${ }^{6}$ As will be seen in the works of Koch and Stanley, even the category of quotation is not necessarily defined as "stable" or "objective."7 Other scholars are comfortable with the looser, more artistic, category of allusion. In recent times this move is noted most especially in Richard Hays. ${ }^{8}$

The terms used to describe the presence of the OT in Paul's writings can at times be too easily appropriated without proper definition-e.g., "citation, direct quotation, formal quotation, indirect quotation, allusive quotation, allusion (whether conscious or unconscious), paraphrase, exegesis (such as inner-biblical exegesis), midrash, typology, reminiscence, echo (whether conscious or unconscious), intertextuality, influence (either direct or indirect), and even tradition, among other terms." "The list of terms can often produce more confusion than help in defining the presence of the OT in Paul's letters.

Stanley Porter helpfully sheds light on the task of studying and locating the OT in the NT. His conclusions are as follows: (1) the goal of the investigation needs to be known by the interpreter; (2) the categories used to define the OT in the NT need to be defined and rigorously applied. A common language among interpreters is not available so one needs to define what he/she is attempting to do; (3) an authororiented approach is preferred over a reader-oriented approach; ${ }^{10}(4)$ one must take into account the variegated ways the OT is present in the NT. Porter's choice example is the book of Philippians which, though having no explicit quotation of the OT, is

\footnotetext{
${ }^{6}$ For example, though Richard Longenecker affirms the presence of allusion in Paul's letter, he finds the study of such things "nebulous" and without proper controls. Therefore, for an understanding of biblical exegesis one's attention needs to turn to quotations alone. Richard Longenecker, Biblical Exegesis in the Apostolic Period (Grand Rapids: Eerdmans, 1999), 91-92.

${ }^{7}$ D.-A. Koch, Die Schrift als Zeuge des Evangeliums: Untersuchungen zur Verwendung und zum Verständnis der Schrift bei Paulus (BHT 69; Tübingen: Mohr Siebeck, 1986); C.D. Stanley, Paul and the Language of Scripture: Citation Technique in the Pauline Epistles and Contemporary Literature (SNTSMS 74; Cambridge: CUP, 1992).

${ }^{8}$ Richard Hays, Echoes of Scripture in the Letters of Paul (New Haven: Yale University Press, 1989). An heir of Hays's approach can be found in Sylvia Keesmaat, "Paul and his Story" in Early Christian Interpretation of the Scriptures of Israel: Investigations and Proposals, ed. by S. Porter and J. A. Sanders (JSNTS 148; Sheffield: Sheffield Academic Press, 1997), 300-333.

"Stanley Porter, "The Use of the Old Testament n the New Testament," in Early Christian Interpretation, 80 .

${ }^{10}$ Porter adopts these terms from Stanley, Paul and the Language of Scripture, 34. Two representative works of the "audience-centered" approach are Christopher M. Tuckett, "Paul, Scripture and Ethics. Some Reflections" in NTS 46 (2000): 403-424; Paul J. Achtemeier, "Omne Verbum Sonat: The New Testament and the Oral Environment of Late Western Antiqutity," in JBL 109/1 (1990): 3-27.
} 
laden with the presence of the OT (e.g., Job 13:6 in Phil 1:19; Isa 45:2 in Phil 2:1011; Deut 32:5 in Phil 2:15). ${ }^{11}$

Porter has provided some conceptual clarity in the midst of the morass of difficulties with this type of research. For the sake of definition, this dissertation will adopt the simple categories of direct quotation and allusion (or echo). ${ }^{12}$ Allusion will be defined as anything that does not fall under the category of quotation. ${ }^{13}$ Point three of Porter's conclusions will be altered in the present study. Instead of choosing between author-centered or audience-centered, this study will opt for a third choice, that is, a canonical-centered approach. A canonical-approach affirms the intentionality of the text at hand in its final form yet resists the temptation to define intentionality on the basis of a reconstructed author behind the text or a particular audience toward which the text is intended. ${ }^{14}$ Also, this particular project's exegetical section does in part focus on the if or where of Paul's use of the OT but is not satisfied with remaining on that level of inquiry. The how and why of Paul's OT reading, that is, a theological/hermeneutical approach, is where the focus of this work is heading. ${ }^{15}$

\footnotetext{
"Porter, "The Use of the Old Testament," 94-96. The works of Koch and Stanley which focus primarily on explicit OT quotations in Paul are surely in mind. See also, Richard Hays, "The Conversion of the Imagination: Scripture and Eschatology in 1 Corinthians," in NTS 45 (1999): 392.

${ }^{12}$ For the exegetical task to follow, the distinctions in the definition of direct quotation is a moot point. Paul's quotation of Isa 49:8 in 2 Cor 6:2 is defined as a "direct quotation" or unaltered Vorlage by Stanley (Paul and the Language, 216-217). This is the only quotation to be found in the exegetical section to follow.

${ }^{13}$ Allusion would also include within it Rosner's categories of "implicit" or "instinctive" use of the OT. Allusion can be an explicit use or an instinctual move of the author as an assumed part of a larger worldview. Brian Rosner, Paul, Scripture, and Ethics: A Study of 1 Corinthians 5-7 (Grand Rapids: Baker, 1994), 17-18. Our investigation into both of these realities is not best attempted by reconstructing the psychology of the presumed author but by allowing the text itself to speak of such allusive presences.

A precise definition of allusion is offered by Michael Thompson, Clothed with Christ: The Example and Teaching of Jesus in Romans 12.1-15.3 (JSNTS59; Sheffield: Sheffield Academic Press, 1991), chapter 1. Thompson (Clothed With Christ, 30) states that a sound method requires "(1) discerning whether a significant parallel exists between two texts, (2) determining the likelihood of their relationship, and (3) seeking to clarify the precise nature of the relationship." Thompson then produces eleven criteria for locating allusion. Before listing and describing his eleven criteria, Thompson (Clothed With Christ, 31) gives the proviso that most scholarly judgments on the presence of allusion in a given text are subjective.

${ }^{14}$ For example, throughout this project the appeal to Paul's reading of the OT will not be an appeal primarily to the historical Paul (though of course this is in part assumed) but to the canonical Paul presented to us in the now stabilized form of the NT canon. See Brevard Childs, The New Testament as Canon: An Introduction (London: SCM Press, 1984), 51. For a criticism of Childs's understanding of a "canonical Paul" see Robert Morgan, "The New Testament Canon of Scripture and Christian Identity," in Die Einheit der Schrift unde die Vielfalt des Kanon (BZNW 118; ed. J. Barton and M. Wolter; Berlin: Walter de Gruyter, 2003), 174.

${ }^{15}$ I would be remiss not to discuss the recent trend toward emphasizing Paul's narrative substructure. The most recent and comprehensive account and critique of this novum in Pauline studies is Narrative Dynamic in Paul: A Critical Assessment (ed. B. W. Longenecker; Louisville: Westminster/John Knox,
} 


\section{Recent Approaches}

Before moving to the constructive aspect of this chapter, which entails the search for a theological approach, it will prove helpful to place this project in the landscape of the various approaches to Paul's use of the OT. Each of the described approaches deserves much more treatment than is given to them. Though great detail will not be given to each approach, an overview will help elucidate the various methodologies and concerns at work when determining the significance of Paul's use of the OT. Also, this will allow the project at hand to define itself amidst these various methodologies, seeking to push forward a theological emphasis in Paul's reading of the OT. ${ }^{16}$ Our attentions turns firstly to an understanding of Paul's OT usage as a damaging alteration of the text's literal sense.

2002). The tip of the narrative iceberg shows itself in various places of Paul's writing belying a much deeper and stronger substructure to Paul's thought. Bruce Longenecker, "Narrative Interest in the Study of Paul: Retrospective and Prospective," in Narrative Dynamics, 11. This reality, according to Longenecker ("Narrative Interest," 11), makes Pauline studies both abstruse-the danger of conjectural subjectivity - and tantalizing - access may be gained to the activity of Paul's thought. Which stories are at work in Paul's thought? The answers may be many. God and Creation, the Fall, Israel, Jesus, and Paul's own conversion are some of the options. See for example, N.T. Wright, The New Testament and the People of God (London: SPCK, 1992), 79, 407; B. Witherington, Paul's Narrative Thought World: The Tapestry of Tragedy and Triumph (Louisville: Westminster/John Knox Press, 1994); R. Hays, The Faith of Jesus Christ: The Narrative Substructure of Galatians 3:1-4:11, $2^{\text {nd }}$ edition (Grand Rapids: Eerdmans, 2001); S. Fowl, The Story of Jesus in the Letters of Paul (JSNTS 36; Sheffield: Sheffield Academic Press, 1990); S. Fowl, "Learning to Narrate our Lives in Christ, "in Theological Exegesis: Essays in Honor of Brevard S. Childs (ed. C. Seitz and K. Greene-McCreight; Grand Rapids: Eerdmans, 1999), 339-354; J.D.G. Dunn, The Theology of Paul the Apostle (Grand Rapids: Eerdmans, 1998), 17-18. The various responses toward narrative and Paul within Longenecker's edited volume are ambivalent and it is beyond the purview of this brief mentioning to interact with all the ideas in Longenecker's edited volume. I will lean on one particular entry, however. Frances Watson rightly surmises that much of the ambivalence toward narrative in Paul may be due to the supposed linear dimension of narrative in light of Paul's emphasis on the vertical in-breaking of God's activity in Christ. God's action in Christ is an ordering principle and any abstract notion of story or narrative not brought under this reality will fall short of Paul's eschatological emphasis. Watson makes the conclusion that the chief underlying principle for Paul is that his teaching be "in accordance with the Scripture." Francis Watson, "Is There a Story in These Texts," in Narrative Dynamics, 234. The "in accordance with the Scripture" principle of Paul does include within it the story of the Old Testament. However, and this seems a key point made by Watson ("Is There a Story," 234), Paul does not incorporate the gospel into the linear flow of events in the OT story but places the gospel in its vertical dimension of God's action in Christ. The OT, therefore, serves as witness to and figural attester of God's actions in Christ. Watson ("Is There a Story," 239) concludes, "The only 'narrative substructure' in Paul is the scriptural narrative or narrative collection from which he draws in order to elucidate an essentially nonnarratable gospel." Though Watson may have not have done justice to the potential for the gospel's storied-form, as seen in the four-fold gospel, the emphasis on the Scriptures of Israel itself as witness to God's eschatological activity (whether in narrative or prophetic literature) is affirmed. ${ }^{16}$ Of course, an appeal to "theology" begs the question of what is meant by theology and this will be defined in due course. 


\section{3.a Damaging Alteration}

Though not the only one to affirm Paul's OT reading as a damaging alteration of the text's intent, Daniel Boyarin has offered one of the more lucid and learned attempts at furthering this view. Boyarin's bold discussion of Paul and the misappropriation of Paul in the history of Christianity has been defined by Wagner as a "brilliant misreading of Paul."17 For our purposes a very brief synopsis is in order. Boyarin defines both his work and Paul's as cultural criticism. ${ }^{18}$ Paul, though often misread in the history of Christianity as a "prop" against the liberation of slaves and women and as a foil for theological anti-Judaism, can be read as a great champion of equality. ${ }^{19}$ Boyarin actually finds Paul arguing for equality in his letters, yet, Paul's likening of equality with sameness seriously damages his social thought. ${ }^{20}$ Paul's passionate appeal toward tolerance (e.g. Gal 3:28-29) is the very death-knell of the particular, differentiated identity of Jews and their cultural practices. ${ }^{21}$ The amalgamation of Jew and Gentile into one by definition of their faith in Christ is a destruction of Jewish particularity. This leads Boyarin to the conclusion that Paul is working within a Platonic worldview, a worldview shared by Philo and demonstrated most especially in Origen, where the spiritual is viewed as ultimately important while the body or fleshly elements of reality are viewed as tainted or of a lower order. ${ }^{22}$

What is of special interest for this study, however, is the appeal Boyarin makes to the damaging effects of Paul's allegorical reading of the OT. ${ }^{23}$ Paul's allegorical reading is an outworking of his platonic worldview (the hierarchy of spirit over body coupled with the universalization of the particular) and is demonstrated in Paul's gramma/pneuma distinction in 2 Cor $3: 6 .^{24}$ This allegorical reading of Paul led him to a generalization and universalizing of the OT with the subsequent result of

\footnotetext{
${ }^{17}$ J. Ross Wagner, Heralds of the Good News, 279 n. 173.

${ }^{18}$ Daniel Boyarin, A Radical Jew: Paul and the Politics of Identity (Berkeley: University of California Press, 1994), 3-4. For a recent review of current scholarship on Paul's use of the OT, which includes a brief interaction with Boyarin, see Kenneth D. Litwak, "Echoes of Scripture? A Critical Survey of Recent Works on Paul's Use of the Old Testament," in CurBS 6 (1998): 260-288.

${ }^{19}$ Boyarin, A Radical Jew, 9.

${ }^{20}$ Boyarin, A Radical Jew, 9.

${ }^{21}$ Boyarin, A Radical Jew, 9.

${ }^{22}$ Boyarin, A Radical Jew, 14-15.

${ }^{23}$ Boyarin, A Radical Jew, chapter 1.

${ }^{24}$ Boyarin, A Radical Jew, 15. On this debated passage see especially Scott J. Hafemann, "The Glory and Veil of Moses in 2 Corinthians 3:7-14," in HBT 14 (1992): 31-49.
} 
demolishing particularity, especially Jewish particularity ("Israel according to the flesh" vs. "Israel according to the promise;" Rom 9-11). ${ }^{25}$

The recent work of Dawson, Christian Figural Reading and the Fashioning of Identity, is in many respects an interlocution with Boyarin. Dawson charges Boyarin with on over-dependence on a postructuralist approach to Paul that ultimately leads Boyarin to a misunderstanding of the relationship between the literal sense and the allegorical sense. ${ }^{26}$ For Boyarin the literal sense of the OT is obliterated by Paul. Dawson, on the other hand, understands the allegorical or figural sense of the Scripture to be a natural extension of the text's literal sense and not at odds with the text's intent. ${ }^{27}$ Dawson's work is undoubtedly a timely and erudite exposition of the relationship between the literal sense and the allegorical sense of Scripture. In due course we will return to his work in greater detail, seeking to draw out the theological implications for this particular project. Suffice it to say, Boyarin understands Paul's reading of the OT as a damaging alteration of the text's literal sense. From this understanding of Paul's appeal to the OT as a damaging alteration, attention is now given to the comparison of Paul's exegesis with both Midrash and Pesher.

\section{3.b Jewish Parallels-- Midrash-Pesher}

Much light has been shed on the discussion of Paul's exegetical practices by way of a descriptive analysis of Paul's contemporaries (or near contemporaries) who read sacred Scripture. One need not read long in the literature before technical terms such as gezerah shewah, qal-wahomer, midrash, or pesher are used as descriptors of Paul's

\footnotetext{
${ }^{25}$ Boyarin, A Radical Jew, 16; see also, John David Dawson, Christian Figural Reading and the Fashioning of Identity (Berkeley: University of California Press, 2002), 6.

${ }^{26}$ Dawson, Christian Figural Reading, chapter 1. Post-structuralism is a shifting of attention to the reader but not the reader as an individual per se, but a reader imbedded in certain "conventions, cultural codes, and historically-conditioned expectations which constitute the reading-community as a sociocultural phenomenon." Anthony Thiselton, New Horizons in Hermeneutics: The Theory and Practice of Transforming Biblical Reading (Grand Rapids: Zondervan, 1992), 496. See Dawson's (Christian Figural Reading, $224 \mathrm{n}$. 2) critique of Boyarin's appropriation of structuralist/post-structuralist categories for his understanding of the letter/spirit distinction.

${ }^{27}$ Dawson (Christian Figural Reading, 47-48) draws out the implications of Boyarin's truncated understanding of allegory. For Boyarin, allegory is a nontextual, independent meaning with its own independent ontological status. Therefore, in Boyarin's understanding both body and spirit, meaning and text are diametrically opposed in allegory. The spiritual meaning can only supersede the body (or literal sense) of the text. Origen, as chief example of an allegorical reader, is a key target for Boyarin ( $A$ Radical Jew, 13,15). Origen embodies the body/spirit dichotomy. Dawson challenges this misunderstanding of both Paul and Origen. Dawson (Christian Figural Reading, 49) states, "The goal of Origen's allegorical reading is to show the connection between these two qualities of personhood (body/spirit), not to allow one to annihilate the other."
} 
particular exegetical activity in various commentaries. Quite often, these terms are appropriated when Paul is committing what is deemed by modern exegetes to be an exegetical sin of sorts. Alternatively, these terms serve to fill out the historical background of Paul's exegetical activity. ${ }^{28}$

\section{3.b.1 Midrash}

As our investigation proceeds, it will be argued that an appeal to these particular categories may not produce the desired effects of clarification. Midrash is a rabbinic term for biblical exegesis, whether oral or written. ${ }^{29}$ Though midrash is not at times unaware of textual-critical and philological problems, it is not primarily "objective professional exegesis" but exegesis concerned with religion. ${ }^{30}$ Childs states that "midrash is, above all, an interpretation of a canonical text within the context and for the religious purposes of a community, and is not just embellishment of tradition. Midrash can be related in different degrees of closeness to the literal meaning of the text, but what is constitutive of midrash is that the interpretation does attach itself to a text." ${ }^{31}$ Therefore, midrash is a rabbinic method of actualization that brings the text from the past into the present for religious purposes of either halakah or haggadah. ${ }^{32}$

\footnotetext{
${ }^{28}$ It should be noted that David Instone-Brewers groundbreaking study of Jewish exegesis (pre-70 C.E.) makes the following conlusion: "The results of the present study show that the predecessors of the rabbis before $70 \mathrm{CE}$ did not interpret Scripture out of context, did not look for any meaning in Scripture other than the plain sense, and did not change the text to fit their interpretation, though the later rabbis did all these things. If the conclusions of this work are correct it demands a fresh examination of the New Testament, which may provide a model for the modern exegete." David Instone-Brewer, Techniques and Assumptions of Jewish Exegesis before 70 C.E. (TSAJ 20; Tübingen: J.C.B. Mohr, 1992), 1. See also Hays, Echoes of Scripture, 11.

${ }^{29}$ G. Porton, "Midrash" ABD 4: 818; Günter Stemberger, Introduction to the Talmud and Midrash (Edinburgh: T\&T Clark, 1996), 234-239.

${ }^{30}$ Stermberger, Introduction, 237; B. Childs, "Midrash and the Old Testament," in Understanding the Sacred Text (ed. J. Reumann; Valley Forge: Judson Press, 1972), 47-59; G. L. Bruns, "Midrash and Allegory: The Beginnings of Scriptural Interpretation" in The Literary Guide to the Bible (ed. R. Alter and F. Kermode; London: Collins, 1987), 625-646; Daniel Boyarin, Intertextuality and the Reading of Midrash (Indianapolis: Indiana University Press, 1990), 14-24.

${ }^{31}$ Childs, "Midrash," 49; see also, E. Earle Ellis, "Biblical Interpretation in the New Testament Church," in Mikra: Text Translation, Reading and Interpretation of the Hebrew Bible in Ancient Judaism and Early Christianity (ed. M.J. Mulder; Philadelphia: Fortress Press, 1988), 703. Boyarin (Intertextuality, 16) has emphasized the intertextual nature of midrash. The Torah is by nature a gapped text needing to be filled by strong readers. These gaps are filled by the strong readers own intertext"the cultural codes which enable them to make meaning and find meaning."

${ }^{32}$ Stermberger, Introduction, 237-238; Manlio Simonetti, Biblical Interpretation in the Early Church: An Historical Introduction to Patristic Exegesis (Edinburgh: T\&T Clark, 1994), 3. Childs's contribution to the definition of midrash is an important voice. Childs ("Midrash," 50-52) challenges G. Wright's separation of "midrash as literary genre" and "midrash as type of exegetical activity." For Childs, form and function go together and the dismissal of midrash from the OT itself is a mistake in Childs's understanding. For, "The heart of the midrashic method is that the interpretation moves from
} 
Also, midrash became associated with hermeneutical principles known as the seven middot of Hillel. ${ }^{33}$ With reference to Pauline use of the OT only two of these seven rules apply, namely, qal-wahomer (an argument from the greater to the lesser) and gezerah shewah (verbal analogy from one verse to another). ${ }^{34}$ Hays, referring to an article by Daube, demonstrates that there is nothing particularly rabbinic about these two examples. ${ }^{35}$ Paul does not seem to be drawing from a particular collection of exegetical rules but is more concerned about the reality of the sacred text conjoined with the reality of God's activity in Christ. ${ }^{36}$

With midrash placed firmly in rabbinic methods of interpretation and literary genre, it should be added that midrash as an exegetical activity is analogous to the ways in which the OT interprets and actualizes itself and the ways in which Paul reads

the biblical text to seek connection with a new situation. But then again, the reverse direction is equally important; namely, the interpretation comes from the situation and moves back to the text. In the first instance, the text interprets the new situation; in the second, the new situation illuminates the text" (52). This type of canonical consciousness coupled with the reality of new situations is at the heart of midrash for Childs, and, it should be added, at the heart of the way in which the OT itself appropriates older texts into newer contexts. Therefore, midrash as genre-later rabbinic activity - and exegetical activity-as observed in the OT itself, bear an analogous relationship with one another (58).

${ }^{33}$ t.Sanh 7.11 introduces the seven rules of Hillel. Expansions of the seven middot of Hillel are given in the thirteen middot of Ishmael and the thirty-two middot named after Eliezer ben Yose ha-Gelili. Stermberber, Introduction, 17-22; see also Longenecker, Biblical Exegesis, 19-21; Wagner, Heralds of the Good News, 6 n.20.

${ }^{34}$ Hays, Echoes, 13; Longenecker, Biblical Exegesis, 20.

${ }^{35}$ Hays, Echoes, 13. See David Daube, "Rabbinic Methods of Interpretation and Hellenistic Rhetoric" HUCA 22 (1949): 239-265; George J. Brooke, Exegesis at Qumran: 4QFlorilegium in its Jewish Context (JSOTS 29; Sheffield: Sheffield Academic Press, 1985), 8-17.

${ }^{36}$ Boyarin (Intertextuality, 16) has emphasized the intertextual nature of midrash. The Torah is by nature a gapped text needing to be filled by strong readers. These gaps are filled by the strong readers own intertext- "the cultural codes which enable them to make meaning and find meaning" (16). Interacting with Boyarin's definition, Childs claims that many modern midrashic studies have made much of the overlap between midrash and Christian allegory ("Critique of Recent Intertextual Canonical Interpretation," $Z A W 115$ [2003]: 182). An example of modern midrashic studies cited by Childs is G. Bruns, "Midrash and Allegory." Childs states that in spite of the overlap between midrash and allegory a fundamental, hermeneutical difference still stands between the two. In midrash, meaning is sought in the interaction of two written texts, whereas allegory seeks meaning in a move that is other than textual (182-183). This also seems to get at the heart of Childs's discomfort with the move Frei makes at the end of his career of joining together the sensus literalis of the Christian tradition with midrash of the Jewish tradition. Hans Frei, "The 'Literal Reading' of Biblical Narrative in the Christian Tradition: Does it Stretch or Will it Break?" in The Bible and the Narrative Tradition (ed. F. McConnell; New York: Oxford Press, 1986), 73-74. Childs (Biblical Theology, 26) states, "It is basic to Christian theology to reckon with an extra-biblical reality, namely with the resurrected Christ who evoked the New Testament witness. When H. Frei, in one of his last essays, spoke of 'midrash' as a text-creating reality, he moved in a direction, in my opinion, which for Christian theology can only end in failure." Christian figural reading is not a text-creating reality but is a faithful listening to a canonical text given in recognition that the text itself (signum) points to a reality beyond itself (res). This is at the heart of Christian figural reading and marks its strongest divergence from midrash. 
and actualizes the OT. ${ }^{37}$ The overlap of midrash as genre and method can, however, lead to a level of confusion regarding precise definition-midrash as genre or midrash as exegetical activity. ${ }^{38}$ The latter is more closely related to the comparison of Paul with "midrash".

It is affirmed that Paul's reading of the OT is seeking to actualize the ancient text in the new eschatological reality of God's activity in Christ and in this sense is like midrash. However, Paul's framework of actualization and reading is of a different sort than his rabbinic contemporaries because of the Christological framework and eschatological context of his reading. To claim that Paul is doing midrash as an attempt to clarify his exegetical practices does not take into account the "true but trivial claim" that all readers of Scripture in Paul's day were seeking to make the holy text relevant to their contemporaries. ${ }^{39}$ In other words, an appeal to midrash, if by this appeal is meant that Paul is seeking to make relevant the ancient text, amounts to a tautology. All scriptural reading seeks to make the sacred text relevant. Moreover, precise definition to the manner and theological framework of Paul's particular reading is not achieved by appeal to midrash. Paul's reading of the OT is intrinsic to his own theological concerns and is not necessarily defined or clarified by extrinsic categories within Paul's religion-historical setting.

\footnotetext{
${ }^{37}$ Jervis's critique of Hays's negative stance toward midrash is an important perspective in the debate. L. Ann Jervis, " 'But I Want You to Know...': Paul's Midrashic Intertextual Response to the Corinthian Worshipers (I Cor 11:2-16)," JBL 112 (1993): 231-246. Jervis ("But I Want You to Know," 233) concedes that there is a distinction between Paul and the rabbis in light of Paul's realized eschatology. However, Hays's understanding that Paul is dictated to by the original meaning of the text-under pneumatic freedom - is a sharp distinction between Jervis's approach and Hays's. For Jervis ("But I Want You to Know," 234), Paul, like rabbinic midrash, is recontextualizing the ancient text, however, this recontextualization is in accordance with the original meaning of the text. Jervis is persuasive on this score and we will return to this issue in due course. It still stands, in our project, that Paul's particular activity of interpretation and actualization of sacred Scripture, though analogous to the rabbis, is of a different sort in light of the categories and framework of Paul's thought. This project, like Jervis, will argue that Paul's reading of the OT is in line with its plain sense, theologically understood.

${ }^{38}$ The recognition of this confusion between midrash as a rabbinic genre and midrash as exegetical activity has led R. Bauckham to adopt the terms 'exegesis' and 'commentary' rather than midrash when referring to the ways in which the NT interprets the OT. Richard Bauckham, Jude and the Relatives of Jesus (Edinburgh: T\&T Clark, 1990), 180 n. 2.

${ }^{39}$ Hays, Echoes, 12. Lim (Pesharim, 51) also states that the use of the term midrash in scholarly circles has become so elastic in its definition that in essence it is "no more than a sexy synonym for interpretation!"
} 


\section{3.b.2 Pesher}

Similarly, comparing Paul's exegesis with that of Qumran has become a staple in Pauline scholarship. It is the emphasis upon the eschatological character of Paul's OT reading that is the key distinguishing marker between Paul and Rabbinic Midrashim. ${ }^{40}$ Likewise, it is at this juncture where the comparison between the eschatological character of Paul's exegesis and the exegetes of Qumran is most acute. ${ }^{41}$ Both are concerned with the actualization of the text, not merely for religious purposes, but for the identifying of current events in the Scriptures of Israel. ${ }^{42}$

The term pesher ("interpretation") is a scholarly construct used to define the overlapping characteristics of the exegetical works of Qumran. ${ }^{43}$ Those characteristics are as follows: "(1) the continuous quotation of sections, large or small, of a biblical text; (2) the use of technical term 'pesher' in the introductory formula of the interpretation; and (3) the identification of a figure in the biblical text with another, apparently contemporary one." ${ }^{44}$ Thus, pesher is its own genre of biblical commentary specifically related to the community concerns: whether of Qumran or another envisaged group. ${ }^{45}$

Therefore, by way of analogy, the pesher exegesis of Qumran bears resemblance to Paul's eschatological hermeneutic. Paul believed God's action in Christ to be the dawning of the eschatological age ("Behold, now is the time," 2 Cor $6: 2$ ) and read Scripture in light of this reality. ${ }^{46}$ With this stated, however, defining

\footnotetext{
${ }^{40}$ E. Earle Ellis, "Biblical Interpretation," 707.

${ }^{41}$ See James H. Charlesworth, The Pesharim and Qumran History: Chaos or Consensus (Grand Rapids: Eerdmans, 2002), 6. Charlesworth describes the hermeneutics of the Pesharim as "fulfillment hermeneutics."

${ }^{42}$ Timothy Lim, Pesharim, (Sheffield: Sheffield Academic Press, 2002), 24. Timothy McLay, The Use of the Septuagint in New Testament Research (Grand Rapids: Eerdmans, 2003) 32; Longenecker, Biblical Exegesis, 28; Koch, Die Schrift, 227-228; Ellis, Paul's Use of the Old Testament, 141; Bauckham, Jude, 216-217.

${ }^{43}$ Those being: Isaiah-4Q161, 4Q162, 4Q163, 4Q164, 4Q165; Hosea-4Q166, 4Q167; Micah4Q14; Nahum-4Q169; Habbakuk-1QpHab; Zephaniah-1Q15; 4Q170; Psalms-1Q16; 4Q171; 4Q173.

${ }^{44} \mathrm{Lim}$, Pesharim, 40. Also, the tendency to understand pesher in a monolithic category should be avoided. Pesherite exegesis is actually more varied displaying a full range of exegesis. Lim, Pesharim, 27; Michael Fishbane, "Interpretation of Mikra at Qumran," in Mikra, 342.

${ }^{45} \mathrm{Lim}$, Pesharim, 52-53. Paul does, at times, do what would be analogous to pesher style commentrary on biblical passages. E.g., Rom 9:7-8; 10:6-7.

${ }^{46}$ See Bauckham. Jude, 217. Hays (Echoes, 172) also recognizes the analogous relationship between Paul and what Hays calls the "covenanters" of Qumran. He also notes three distinguishing marks. 1) Paul is universal in his exegesis whereas the covenanters were sectarian in spirit. 2) The Scrolls do not precisely parallel Paul in that Paul believed the eschatological event to have already happened, 3) Qumran exegesis is apologetic while Paul's exegesis is community-oriented. See also, Mark Adam
} 
Paul's exegesis as pesher does not take the interpreter far enough in describing the substantial force of Paul's eschatological exegesis. ${ }^{47}$ As a historical warrant or identification of genre, this description may prove helpful. ${ }^{48}$ But the concerns of the pesharim and the methodology of exegesis employed to display and justify those concerns are relevant to and contained within that particular community. ${ }^{49}$ Simply to apply this technique to Paul would run rough-shod over the distinguishing features of the actual content of both parties. ${ }^{50}$ That Paul read the Scriptures eschatologically is assumed, but the Christological character of Paul's eschatological reading places it in a category of its own. To this we will return shortly. ${ }^{51}$ Having observed the distinction between Paul's OT reading and midrash/pesher, attention is now given to a textcritical approach to understanding Paul's appeal to the OT.

\section{3.c Citation Mechanics and Altered Vorlage}

From a text-critical perspective, the works of Koch and Stanley stand at the foreground in recent literature in their attempt to understand the mechanics of Paul's citation of the OT and the logic behind Paul's alteration of his Scriptural Vorlage for literary/theological purposes. ${ }^{52}$ Stanley's work in many ways is an appreciative modification of Koch's as he focuses on the mechanics of the citations themselves. ${ }^{53}$ Stanley's stated goal is to 1) demonstrate that Paul actively adapted the wording of his biblical quotation to communicate his own understanding of the passage and to short-

\footnotetext{
Elliot, The Survivors of Israel: A Reconsideration of the Theology of Pre-Christian Judaism (Grand Rapids: Eerdmans, 2000), 540-552.

${ }^{47}$ Pace Ellis, Paul's Use of the Old Testament, 139-147; see Lim, Pesharim, 82-83.

${ }^{48}$ It should be added that the concern to define Paul's exegesis by external categories of description is a historical venture, of the comparative religious sort, that often does not take the unique theological character of Paul's exegesis seriously. Hays's Echoes of Scriptures is a notable example of the opposite of this mindset.

${ }^{49}$ This particular feature is highlighted by Charlesworth (The Pesharim, 16, 68) with the terms "selfserving and idiosyncratic" used as descriptors. See also Fishbane, "Interpretation of Mikra at Qumran," 376-377.

50 "In any case, it is not clear what is to be gained by calling Pauline or Matthean exegesis 'a midrash pesher'. Both Paul and Matthew have their own concerns, hermeneutical principles and methods of scriptural exegesis and these are best illuminated within their own contexts." Lim, Pesharim, 83. The term "midrash-pesher" has been popularized by Ellis, Paul's Use of the Old Testament, 139-147; Prophecy and Hermeneutic in Early Christianity (WUNT 18; Berlin: Mohr Siebeck, 1978), chapter 10.

${ }^{51}$ Special attention will be given to peshat and derash in the section on "plain sense."

${ }_{53}^{52}$ Koch, Die Schrift als Zeuge des Evangliums and Stanley, Paul and the Language of Scripture.

${ }^{53}$ Stanley, Paul and the Language of Scripture, 3.
} 
circuit other competing interpretations and 2) to show that Paul's adapting was an unconscious reflection of the literary conventions of his day. ${ }^{54}$

Koch's seminal work led the field in exploring and defining Paul's citation techniques. ${ }^{55}$ Stanley challenges Koch's "reader-centered" approach on the basis of the poor literary abilities of the recipients of Paul's letters. ${ }^{56}$ According to Stanley, Koch expects too much of Paul's readers. This leads to Stanley's narrowly defined criteria of citation. They are as follows: (1) citations are present when introduced by an explicit quotation formula; (2) when accompanied by a clear interpretive gloss; (3) when standing in a demonstrable syntactical tension with their present Pauline surroundings. ${ }^{57}$

Stanley's work also emphasizes that Paul mostly relied on the Septuagintal tradition and at times altered that Vorlage for his own theological reasons. Stanley warns against taking the claim of his work too far. Paul's adaptations do not reflect lapses in memory but reflect his "intentional adaptation" of the text at hand. ${ }^{58}$ At the same time, Paul was not involved in manipulative proof-texting. Stanley concludes that most of the adaptations uncovered in his study have little effect on the meaning of the original OT text. ${ }^{59}$

\footnotetext{
${ }_{55}^{54}$ Stanley, Paul and the Language of Scripture, 29.

${ }^{55}$ Koch, Die Schrift, 11-23. Stanley (Stanley, Paul and the Language of Scripture, 35) helpfully lists the seven citation criteria delineated by Koch. Legitimate quotation are found 1) when accompanied by a citation formual; 2) when the same words appear in another context where they are marked clearly as a citation; 3) when followed by an interpretive gloss; 4) when the words in question stand out syntactically from their Pauline context, showing that they were not first formulated for their present position; 5) when the passage differs stylistically from the verses that surround it; 6) when the

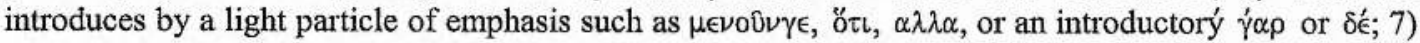
when the verse reproduces a tradition that the author clearly assumes will be familiar to his readers.

${ }^{56}$ Stanley, Paul and the Language of Scripture, 35.

${ }^{57}$ Stanley, Paul and the Language of Scripture, 37. Porter ("The Use of the Old Testament in the New Testament, 82) critiques Stanley on this score. For Porter, Stanley has not clearly defined a methodology, rather, he has "cut the Gordian knot" by demonstrating the bare minimum that one can identify as a quotation in Paul.

${ }^{58}$ See especially Wagner's (Heralds of the Good News, 23-25) criticism of Stanley and Koch on this issue. Wagner, concurring with Koch and Stanley, affirms the impossibility of Paul's "memory lapse" as an explanation of Paul's altered readings. Wagner does not find persuasive the fact that Paul only made use of Scripture in its textual form. It is quite likely that Paul would have had larger portion of Israel's Scripture memorized or at least very well known. See Martin Hengel, The Pre-Christian Paul (London: SCM Press, 1991), 34-37.

${ }^{59}$ Stanley, Paul and the Language of Scripture, 359. A similar conclusion is drawn by Wagner, Heralds of the Good News, 345-346.
} 
The conclusions of Stanley have been challenged by Timothy Lim's 1997 monograph. ${ }^{60}$ According to Lim, Stanley does not take into account the possibilities of multiple Vorlagen for Paul, a Jew who could read Aramaic and Hebrew. ${ }^{61}$ Also, the possibility of Paul's own translation of a text into Greek is an option Lim introduces. ${ }^{62}$ Overall, Lim argues that simply because a quotation by Paul is written in Greek does not necessitate a Septuagintal backgroud. ${ }^{63}$

Richard Bauckham has drawn similar conclusions regarding the assumed necessity of choosing one text tradition over another in his discussion of the LXX and the MT in Acts $15 .{ }^{64}$ Bauckham draws on historical evidence to show that slight changes or variants of the text would not have been awkward in the first century. ${ }^{65}$ In fact, Jewish exegetes were accustomed to choosing among variant readings or making use of more than one. A Jewish Christian exegete, familiar with both the Greek and the Hebrew, is not precluded from observing the LXX as a legitimate way of reading the text (for reading involves interpretation). ${ }^{66}$ But this is not to assume that the Hebrew text is being downplayed by the exegetical potential of the Greek text nor does it prove the unfamiliarity of a NT author with a Hebrew text form. ${ }^{67}$ Though

\footnotetext{
${ }^{60}$ Timothy Lim, Holy Scripture in the Qumran Commentaries and Pauline Literature (Oxford: Clarendon Press, 1997).

${ }^{61}$ Lim, Holy Scripture, 143. See also, Timothy McLay, The Use of the Septuagint, 26.

${ }^{62} \mathrm{Lim}$, Holy Scripture, 26-27. Wagner (Heralds of the Good News, 345) takes up Lim's challenge in his thesis by exploring the various sources Paul may have used. His conclusions are that Paul did operate with a Greek text very much like the LXX.

${ }^{63}$ Lim, Holy Scripture, 26. McLay (The Use of the Septuagint, 43 n. 12) agrees with Lim's statement but still finds the NT evidence to support the contrary.

${ }^{64}$ Richard Bauckham, "James and the Jerusalem Church," in The Book of Acts in Its Palestinian Setting (ed. R. Bauckham; Grand Rapids: Eerdmans, 1995), 452-456.

${ }^{65}$ The Rabbinic term for these slight alterations is 'al tiqurê.

${ }^{66} \mathrm{LXX}$ is obviously being used loosely since the LXX in its present form has come to us from Christian hands no earlier than the fourth century. See D. Moody Smith, "The Pauline Literature," in Scripture Citing Scripture: Essays in Honour of Barnabas Lindars (ed. D.A. Carson and H.G.M. Williamson; Cambridge: Cambridge University Press, 1988), 273; see Moisés Silva and Karen Jobes, Invitation to the Septuagint (Grand Rapids: Eerdmans, 2000); McLay, The Use of the Septuagint. With Smith ("Pauline Literature," 273) it may be better to speak of Paul's usage as septuagintal rather than depending on the LXX.

${ }^{67}$ Bauckham, "James and the Jerusalem Church," 456. See also, Christopher Seitz, Figured Out: Typology and Providence in Christian Scripture (Louisville: Westminster/John Knox, 2001), 41. David Sapp has concluded that Paul must have relied on a Hebrew Vorlage when alluding to Isaiah 53 in his atonement theology. The LXX and MT diverge on vicarious atonement language (especially Isa 53:10). David Sapp, "The LXX, 1QIsa, and MT Versions of Isaiah 53" in Jesus and the Suffering Servant, 170192.
} 
Paul's quotations often overlap with an LXX form, this does not preclude the strong possibility of Paul's deep familiarity with the Hebrew text as well. ${ }^{68}$

Overall, the presence of slight alterations in Paul's quotations of or allusions to the OT does not leave Stanley with the picture of Paul manipulating the text towards his own ends. ${ }^{69}$ As has been noted, Stanley regards the alterations of the text as having little effect on the original meaning of the text. Also, that Paul understood the Scriptures of Israel to be authoritative for the church (Gentile church) is an agreed upon reality as observed in an inductive appeal to Paul's use of Scripture and the external reality of Paul's Jewish heritage. ${ }^{70}$ Therefore, Paul's new eschatological situation, without doubt, alters the context of Paul's OT reading. ${ }^{71}$ However, it does not follow that Paul's new situation meant that Paul was no longer seeking to listen faithfully to the text. ${ }^{72}$ Text-critical studies (as found in Koch and Stanley) often focus over much on the methodology of the citations themselves with less attention given to the actual theological substance or logic of Paul's reading. ${ }^{73}$ Our study intends to show that central to Paul's use of the OT is not mechanical methodology, though not denying the presence of this, but a theological substructure that focused and formed Paul's reading habits and appropriation of the OT. From the specifics of a textlinguistics approach, the thematic approach of Wilk will be now be explored.

\footnotetext{
${ }^{68}$ See Smith, "The Pauline Literature," 273. Smith also states that though Paul is deeply familiar with the Hebrew text his epistolary production as targeted to Gentiles may be one simple angle at understanding the motivation behind Paul's septuagintal quotation. It should be stated that Paul directly quotes the OT only once in the specific passage with which this thesis is dealing (2 Cor 6:2). This quotation is in agreement with both the LXX and the MT. The more subtle presence of allusion in our passage of choice reflects conceptual overlap between Isaiah and Paul more than one-to-one verbal agreement between an assumed or argued for Vorlage. See Silva and Jobes, Invitation to the Septuagint, 203. In the narrative description of Isaiah's internal movement the MT will be followed and discussed. Where substantial conceptual differences between the LXX and the MT are observed they will be dealt with in the footnotes. Again, it should be stressed that in the passage of choice for this thesis Paul's theological reading of the OT is taking place on a conceptual and theological plane and not a text-critical plane.

${ }^{69}$ McLay (The Use of the Septuagint, 28, 36) states that there is no one explanation for the differences between the quotations in the NT and their sources. The possibilities are as follows: 1) textual corruption; 2) alternative sources; 3 ) quotation from memory; 4) an author's freedom with respect to the use of sources.

${ }^{70}$ Stanley, Paul and the Language of Scripture, 338; J. L. Martyn, Theological Issues in the Letters of Paul, (Edinburgh: T\&T Clark, 1997), 159.

${ }^{71}$ See Hays, "The Conversion of the Imagination."

${ }^{72}$ Contra Stanley, Paul and the Language of Scripture, 78; see Wagner, Heralds of the Gospel, 25-26. This is of especial importance if one takes into account Paul's Jewish interlocutors and his persuasive appeal to Scripture.

${ }^{73}$ McLay, The Use of the Septuagint, 145.
} 


\section{3.d Four Central Themes}

Florian Wilk's published thesis Die Bedeutung des Jesajabuches für Paulus is an extended treatment of Paul's use of Isaiah in the corpus of his undisputed letters. Wilk organizes Paul's interpretation of Isaiah under four main categories:

"Christusbotschaft," "Selbstverständnis," "Israelfrage," and "Parusieerwartung.,"74 The great strength of Wilk's work is his comprehensive approach to Paul's use of Isaiah in his letters, though Wilk gives primary attention to quotations and undisputed allusions. ${ }^{75}$ Wilk's greatest strength, that is, his comprehensiveness, may also be his weakness, at least in relation to the passage of choice in this work. Wilk gives a broad overview of Paul and his use of Isaiah. This broad overview, however, necessarily limits the particular examples given and the contribution that Isaiah makes in the particular argument in Paul's writing. In our exegetical example, 2 Cor 5:14-6:10, express attention will be given to the way Paul reads Isaiah and to the import of this reading for Paul's argument in 2 Corinthians. Wilk is limited on this score and necessarily so because of the comprehensive nature of his work. Recently, J. Ross Wagner has set his reading of Isaiah in Romans over against Wilks's by describing his own work as a "thick description" of the ways in which Paul read Isaiah in a particular circumstance. ${ }^{76}$ Similarly, this work is limited in scope to Paul's reading of Isaiah in 2 Cor 5:14-6:10. Wilk's work has many salient features to commend itself and this present work is in large agreement with Wilk that Isaiah influenced and shaped Paul's understanding of the message of Christ and Paul's own selfunderstanding.

\footnotetext{
${ }^{74}$ Florian Wilk, Die Bedeutung des Jesajabuches für Paulus (Göttingen: Vandenhoeck and Ruprecht, 1998). See also Wilk, "Paulus als Interpret der prophetischen Schriften." The latter is a condensed form of the major argument of Wilk's thesis.

${ }^{75}$ Wilk may fall prey to Porter's earlier criticism.

${ }^{76}$ Wagner, Heralds of the Good News, $15 \mathrm{n} .55$. My interaction with Wilk will be mostly limited to the footnotes. Wilk does not observe the import role the Servant of Isaiah 40-55 plays in 2 Cor. 5:14-21. Actually, I failed to see Wilk even entertain the idea that 2 Cor 5:21 echoes Isaiah 53. Also, the theme of the servants of the Servant in Isaiah 53-66 is absent from Wilk's work. This displays the all too often approach of a NT scholar to the NT use of the OT. Our reading often over focuses on the NT side without detailed attention given to, for example, Isaiah's own final form and shape (the shape Paul would have been reading).
} 


\section{3.e Ecclesiastical Hermeneutic}

Without doubt, the most significant work on Paul and the OT in recent times is Richard Hays's Echoes of Scripture in the Letters of Paul. ${ }^{77}$ Challenging the likes of Harnack and Bultmann, Hays emphasizes the important role the OT played in Paul's theologizing and Gentile ministry. For Paul, the Scriptures are not a marginalized aspect of his ministry and thought. They form the every essence and substance of his reflection on God and the world. Therefore, if "the vocabulary and cadence of Scripture are deeply imbedded on Paul's mind," one would expect the apostle to allude to (obvious intertextual referent) or echo (more subtle intertextual referent) those Scriptures that form Paul's worldview. ${ }^{78}$

Hays presses the issue forward by making use of the term "intertextuality.,"79 Intertextuality, of the sort Hays is advocating, is a textual phenomenon where earlier texts are imbedded in later texts. ${ }^{80}$ Hays pursues his project along similar lines as Michael Fishbane's Biblical Interpretation in Ancient Israel. ${ }^{81}$ Revelation and tradition are interwoven in a mutually dependent fashion. ${ }^{82}$ Paul, as recipient of a received tradition, understands the tradition in a new way in the light of his received revelation. As a prophetic figure, Paul carries the proclamation forward, bringing the past revelation in line with God's new conditions. ${ }^{83}$ Hays is not, therefore, making use of intertextuality in the postmodern/deconstructive fashion of Kristeva and Barthes but is limiting himself to the textual aspect of Paul's reading of the Scriptures as "inner-biblical exegesis." ${ }^{\prime 84}$ Hays often uses theatrical imagery in his discourse, as in the following description of Paul's inner-biblical / intertextual exegesis:

\footnotetext{
${ }^{77}$ This is displayed in Litwak's ("Echoes of Scripture?") review of current research on Paul and the OT. His article centers, for the most part, on the reception and critique of Hays's work. For a sampling of those who have adopted Hays's art of reading see Gail R. O'Day, "Jeremiah 9:22-23 and I Corinthians 1:26-31 A Study in Intertextuality," JBL 109 (1990): 259-267; S.C. Keesmat, "Exodus and the Intertextual Transformation of Tradition in Romans 8:14-30" JSNT 54 (1994): 29-56; "Paul and His Story," in Early Christian Interpretation of the Scriptures of Israel, 300-303; Brian Rosner, Paul, Scripture and Ethics; Karen Jobes, "Jerusalem our Mother: Metalepsis and Intertextuality in Galatians 4.21-31," WTJ 55 (1993): 299-320, J. Ross Wagner, Heralds of the Gospel.

${ }^{78}$ Hays, Echoes of Scripture, 16.

${ }^{79}$ Hays, Echoes of Scripture, 14-21.

${ }^{80}$ Hays, Echoes of Scripture, 14.

${ }^{81}$ Michael Fishbane, Biblical Interpretation in Ancient Israel (Oxford: Clarendon Press, 1985).

${ }^{82}$ Fishbane's categories are traditum (fixed revelation) and traditio (the moving tradition). Fishbane, Biblical Interpretation, 7-14.

${ }^{83}$ Hays, Echoes of Scripture, 14.

${ }^{84}$ The failure to take note of this distinction has been the source of criticism for Hays. Hays (Echoes of Scripture, 15) himself claims that he is not thinking in terms of Kristeva and Barthes, that is, intertextuality as the mutual interplay between a text and all the other semiotic "texts" of a culture,
} 
Anyone who has ever acted in a play knows the experience of discovering that lines from the play come unexpectedly to mind in real-life situations different from the original dramatic context. The aptness of the quoted line does not depend on exact literal correspondence between the original meaning and the new application. Indeed, the wit and pleasure of such quotations lie partly in the turning of the words to a new sense. In such cases, the act of quotation becomes an act of figuration, establishing a metaphorical resonance between drama and life. Paul's uses of Scripture often have a similar character: Scripture is for him the text of the world-play in which he performs and from which familiar lines repeatedly spring to life in new situations. ${ }^{85}$

The preceding quotation displays clearly Hays's view of Paul and the OT. Paul is acting out on the stage of God's new action in Christ, and for Paul, the script he refers to most often is the foundation of his worldview, the Scriptures of Israel.

With the above stated, it does not follow for Hays that Paul is attending to the text itself as a prioritizing principle per se, or to use later theological parlance, the norma normans non normata. For Hays, Paul's exegesis is fundamentally an ecclesiocentric exegesis concerned foremost with the spiritual transformation of the Pauline communities of faith. ${ }^{86}$ According to Hays, the gramma/pneuma distinction of 2 Cor 3:6 is a fundamental hermeneutical principle. ${ }^{87}$ Gramma is not equated with graphe, according to Hays. Therefore, it would be misleading to state the issue as a Spirit/Scripture debate. The issue Paul is driving home in this distinction is the

written or unwritten. For an approach that adopts this form of post-structuralism see Boyarin's Midrash and Intertextuality. Hays is working with literary conventions, borrowed especially from John Hollander's, The Figure of Echo: A Mode of Allusion in Milton and After (Berkeley: University of California Press, 1981) and has especially defined his work as such. For an example of one who thinks the term "intertextuality" is not salvageable as a term on the basis of its genesis and association with post-structuaralist/deconstructionist hermeneutics see Thomas R. Hatina, "Intertextuality and Historical Criticism in New Testament Studies: Is There a Relationship?" BibInt 7 (1999): 28-43. Also see the exchange between Green and Hays in Paul and the Scriptures of Israel (ed. C.A. Evans and J.A. Sanders; JSNTS 83; Sheffield: Sheffield Academic Press, 1993). It must be stated, however, that Hays has defined his terms and the disagreements offered by Hatina and Green amount to a genetic fallacy. ${ }^{85}$ Hays, Echoes of Scripture, 33. Hays (Echoes of Scripture, 29-32) gives seven criteria for identifying an echo in Paul. 1) Availablity; 2) Volume; 3) Recurrence; 4) Thematic Coherence; 5) Historical Plausibility; 6) History of Interpretation; 7) Satisfaction. See also, Richard Hays, "Who Has Believed Our Message? Paul's Reading of Isaiah," SBL 1998 Seminar Papers, 205- 224.

${ }^{86}$ Hays, Echoes of Scripture, 86. Sanders counters the ecclesiocentric hermeneutic of Hays arguing for a theocenric hermeneutic. James A. Sanders, "Paul and Theological History," in Paul and the Scriptures of Israel, 53-54. Sanders ("Paul and Theological History," 54) states that central to Paul's reading of the OT is Paul's understanding of "but one God at work throughout the Scripture." The Scriptures provide a divine pattern for God's present activity.

${ }^{87}$ Hays (Echoes of Scripture, 149-152) does qualify this by stating the 2 Cor 3:6 is not explicitly about hermeneutical principles but the implication of the new covenant on hermeneutics are manifest. 
necessity of Spirit-embodied communities in their reading of Scripture. ${ }^{88}$ "In other words it is a ministry that centers not on texts but on the Spirit-empowered transformation of the community." ${ }^{89}$ Gramma remains lifeless and dead as a script if it is not embodied by a community.

It is at this point that Hays is at his most controversial on the relationship between the nature and role of the text and the reading and appropriation of it by Paul. For Hays, this "new covenant reader competence" is described as a "hermeneutical freedom." $"$ Scripture is not to be read "slavishly" according to the gramma but freely and imaginatively as "a metaphor, a vast trope that signifies and illuminates the gospel of Jesus Christ." "91 Although Hays is not setting Scripture against Spirit-led reading, the text becomes more of a playground for interpretive creativeness in Paul's hands. The relationship of the text and the subject matter of which it speaks is not necessarily an organic relationship of text and subject but a relationship of spiritual connectedness in hermeneutical freedom.

It is on this score that David Dawson's critiques of Hays are most pertinent. Dawson compares and contrasts Boyarin's approach to Paul with Hays's." "Boyarin defends the texts against the constraints of the Spirit, while Hays celebrates the Spirit against the constraints of the text." ${ }^{, 93}$ Where Boyarin makes too much of categories such as "signified and signifiers," Hays follows suit in pressing too hard the distinction between writing and non-writing. ${ }^{94}$ According to Dawson, the movement of the Israelites from the glory of Moses's face to the text of Old Testament Scripture should not be described with the term "instead," as it is for Hays. ${ }^{95}$ Dawson claims that there is no warrant for the claim that the people of Israel, or Paul for that matter, chose a text over a transfigured person, or vice versa. ${ }^{96}$ This fundamental assumption of the superiority of the Spirit to texts flaws the way in which Hays reads Paul. ${ }^{97}$

\footnotetext{
${ }^{88}$ Hays, Echoes of Scripture, 130-131.

${ }^{89}$ Hays, Echoes of Scripture, 130.

${ }^{90}$ Hays, Echoes of Scripture, 149.

${ }^{91}$ Hays, Echoes of Scripture, 149. Similarly, typology for Hays (Echoes of Scripture, 100) is a tropes, "an act of imaginative correlation."

92 Boyarin does the same in A Radical Jew.

93 Dawson, Christian Figural Reading, 33.

${ }^{94}$ Dawson, Christian Figural Reading, 34. For clarity's sake, according to Boyarin, Paul destroys signifiers for the meanings they signify. Thus, "Israel according to the flesh" is destroyed in favor of its true meaning, "Israel according to the Spirit." For Boyarin, this is a damaging alteration.

${ }_{95}$ Dawson, Christian Figural Reading, 35.

${ }^{96}$ Dawson, Christian Figural Reading, 35.

${ }^{97}$ Dawson, Christian Figural Reading, 35
} 
Dawson's conclusions are of import for this present work so they will be quoted in full.

The force of both Boyarin's and Hays's reading is, finally, to

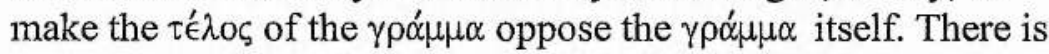
little doubt that Hays wants to have it otherwise, insisting that 'those who turn to the Lord are enabled to see through the text to its telos, its true aim.' For Hays, the veil is not the letter of the text but the state of the reader's mind. When that mind is improperly disposed, the text remains veiled. When that mind is properly disposed, one sees through the veil to the text's true aim. But Boyarin shows that Hays's reading does not finally make the $\tau \dot{\epsilon} \lambda$ os of the text an extension rather than an opposition to the text. Paul's 'hermeneutic of transparency,' as described by Hays, is not a hermeneutic of figural extension. By presenting the work of the Spirit as forming community independently of the text (ideally, without the aid of any texts at all), Hays's notion of transparency - seeing through the text-falls short of figural meaning as an extension of the text. Boyarin is not off target, therefore, in seeing little practical import in Hays's invocation of the classic contrast between typology and allegory. ${ }^{98}$

It is precisely at this point where the project at hand seeks to fill in the gap on the relationship between the literal sense and its figural capacity for Paul. It will be argued in due course that Paul's reading of the OT, though properly described as at times allegorical or typological, is not an obliteration of the text itself but a genuine extension of the text in light of its true subject matter in Jesus Christ. ${ }^{99}$

\footnotetext{
${ }^{98}$ Dawson, Christian Figural Reading, 36.

${ }^{99} \mathrm{It}$ is possible that a development of thought has taken place for Hays on the issue of figural reading. In a recent Pro Ecclesia article, "Can the Gospels Teach Us to Read the Old Testament?" Pro Ecclesia XI (2002): 402-418, an emphasis is found on the reciprocal relationship between NT and OT, an emphasis not found in Echoes of Scripture. Hays ("Can the Gospels," 405) states that not only does the NT teach us how to read the OT but the OT teaches us how to read the NT as well. Hays now emphasizes that the NT teaches us to read the OT figuratively and retrospectively as a prefiguring of the truth definitively embodied in Jesus. "Such retrospective reading neither denies nor invalidates the meaning that the OT text might have had in its original historical reality" ("Can the Gospels," 414). Hays ("Can the Gospels," 415) also appeals to Hans Frei's definition of figural reading where both type and antitype flow reciprocally toward one another enhancing the meaning of both. The true meaning or significance of the OT text is not dismembered when read in light of Jesus Christ but is read in its true light. For text and subject matter are not divorced in the divine economy. Put in other words, Hays seems to be speaking now of the organic connection between the text's literal sense and its figural capacity rather than the antithesis presented previously between writing and non-writing.
} 


\section{Paul's Sui Generis Character of OT Reading}

As has been mentioned previously, there are analogous relations between Paul's exegesis and the exegesis of his contemporaries. The question that has been asked is, "How far do such analogies take us?" Recalling the exegesis of the pesharim, one cannot divorce the communal concerns of those exegetes from their method of interpretation. A similar statement can be made of Paul. His particular concerns and understanding of the eschatological moment in Christ distinguishes his approach from other analogous or competing approaches. Hans Hübner is correct in surmising that Paul, and the other NT authors as well, do not take their readings of Scripture to be one option among several valid readings. For Paul, Christological reading of the OT is the only correct interpretation of Israel's Scripture. ${ }^{100}$

Hübner continues, "The conclusion to be drawn from this is that a mere comparison of terms, motives, methods of interpretation, etc., in the field of history of religion proves little in the face of content differences, because these differences-and everything depends on this!- -are theological differences." 101 The present work seeks to take seriously Hübner's claim. The validity of a religionsgeschictliche approach is not necessarily being challenged here. What is being claimed is the importance of taking seriously the theological distinctiveness of Paul's approach to the OT. Paul's theological approach sets him apart from his Jewish contemporaries and can best be described as a sui generis reality of the self-sustaining sort. ${ }^{102}$

\footnotetext{
${ }^{100}$ Hans Hübner, "New Testament Interpretation of the Old Testament," 334. Hübner ("New Testament Interpretation of the Old Testament," 337) also states that comparison of the parallels between NT authors and their Jewish counterparts is a formal activity. To get at the heart of the matter, one must analyze the NT's use of the OT phenomenologically. For example, the formal similarities between Paul and Qumran are apparent. "But what is crucial in the New Testament eschatological interpretation is the fact that by the christological understanding of Scripture it has been given a direction clearly different from Qumran or elsewhere in Judaism." Hübner, "New Testament Intepretation of the Old Testament," 337, see also Koch, Die Schrift, 202. It should be stated that the term "Christological" is being deployed here as referring to God's action in Christ and all that entails (thus ecclesiology would fall under this rubric but understood as dogmatically placed in the larger category of Christology and not as an abstract theological category). Also, the appeal to Paul's sui generis reading of the OT is not meant to remove Paul from his particular place and time. Without doubt, Paul did not have the hermeneutical sensibilities of modernist readings of Scripture and it would be anachronistic to suppose that he did or even wish that he had. What is being emphasized is the unique eschatological context of Paul's reading and his understanding of Scripture's unique subject matter, that is, Jesus Christ (see Brevard Childs, The Struggle to Understand Isaiah as Christian Scripture: A Hermeneutical Study [Grand Rapids: Eerdmans, 2004], 16-19). This sets Paul's reading, and the NT for that matter, in a unique context in his temporal placement.

${ }^{101}$ Hübner, "New Testament Intepretation of the Old Testament," 337.

${ }^{102}$ See Barth's comments on this topic, Eberhard Busch, Karl Barth: His Life from Letters and Autobiographical Texts (Grand Rapids: Eerdmans, 1994), 348-349; see also Frei's comments on Barth,
} 
Paul's warrant for such a reading of the OT is the revelation of God in Christ (cf. Gal 1). As shared with the other NT authors, this is his starting point and the center from which his thinking proceeds. ${ }^{103}$ Without doubt, this may not be persuasive to some looking for the empirical proof validating such a move. Again, however, for Paul, the proof is that God has acted concretely in Christ and all reality centers around this eschatological movement of God. ${ }^{104}$ Scripture as the living voice of God spoke of and speaks of God's definitive movement in Christ and all that that entails. Brevard Childs highlights this theological dialectic between text as witness and the perspective of faith in Christ in his discussion of Paul's interpretation of Exodus 32-34 in 2 Cor 3. He states, "He (Paul) brings to the text the perspective of faith which had learned to hope in Christ (v. 12), but he brings from the text a witness which conversely forms his understanding of God and shapes the Christian life through his Spirit." ${ }^{105}$ The dialectical relationship between text as witness and norm, the viva vox Dei, and the text's subject matter as God's action in Jesus Christ (and all that that entails) must be highlighted if one is to appreciate Paul's use of the OT. To develop this point further, our attention now turns to a canonical approach and its potential for adjudicating the current issue.

\section{A Canonical Approach to Paul and the OT}

Brevard Childs's constructive work on biblical theology provides important insights into the relationship between the testaments and one's approach to interpreting Christian Scripture theologically in the form in which it has been received, that is, a two-testament canon. It is in this locus that Childs's thought has developed from his earlier clarion call, Biblical Theology in Crisis (1970), to his more mature formulations in Biblical Theology of the Old and New Testaments (1992). In Childs's

Hans Frei, Types of Christian Theology (New Haven: Yale University Press, 1992), 38-46. This eschatological Christocentrism is the foundation and center of Paul's thought.

${ }^{103}$ The appeal to Paul's sui generis reading of the OT is not to set Paul apart from his Christian contemporaries. They, of course, shared many similar features of OT reading. This appeal is namely in dialogue with a history of religions approach to the issue at hand. Also, Paul's writings are the earliest Christian writings, and he, in many respects, leads the way in his OT reading.

${ }^{104}$ See especially Herman Ridderbos, Paul: An Outline of His Theology (Grand Rapids: Eerdmans, 1997); Gerhardus Vos, "Paul's Eschatological Concept of the Spirit," in Redemptive History and Biblical Interpretation: The Shorter Writings of Geerhardus Vos (ed. R. Gaffin; Phillipsburg: P\&R Publishing, 1980), 91-125.

${ }^{105}$ Brevard Childs, The Book of Exodus (OTL; Louisville: Westminster Press, 1974), 624. See also, Morna D. Hooker, "Beyond the Things that are Written? St. Paul's Use of Scripture," in NTS 27 (1981): 307-308. 
earlier work, the starting point for biblical theology is the examination of how the NT interprets the OT. ${ }^{106}$ Childs subsequently moved away from this construct toward an understanding of biblical theology that allows the two Testaments to speak in their own discrete ways about God and his action in Jesus Christ. This move safeguards the integrity of each witness as Childs seeks to do justice to both testaments as witnesses to Jesus Christ. 107 "The Old is understood by its relation to the New, but the New is incomprehensible apart from the Old." 108

With this stated, one can still observe the analogical relationship between the NT's reading of the OT and later Christian biblical theological reflection. ${ }^{109}$ The distinct form of Christian biblical theological reflection, however, is of a different sort now that it possesses a two-testament canon. "Both testaments make a discrete witness to Jesus Christ which must be heard, both separately and in concert." 110 Therefore, biblical theology is not a mirror-representation of the NT's use of the OT nor is OT reflection from a Christian standpoint reduced to the way in which the NT receives the OT. At the same time, it is affirmed that an analogous relationship exists between the way Paul read the OT and later Christian reflection on the OT in light of its subject matter, Jesus Christ. These two aspects must continuously be borne in mind. Thus, the present study is still an important task, though not the only task, in biblical theological reflection. For this reason, we turn to Childs's particular contribution to Paul's reading of the OT.

Childs's approach to biblical theology takes seriously the conjoining of the signum (sign of the biblical text) and the res (the subject matter or substance toward which the signum pointed). To help clarify this distinction, Childs points to conceptual categories of erklären (description) and verstehen (understanding or "penetrat[ing] to the content of the witness"). ${ }^{111}$ For Childs, exegesis should not be limited to the task of description alone. This type of exegesis is reductionist and limits

\footnotetext{
${ }^{106}$ Brevard Childs, Biblical Theology in Crisis (Philadelphia: Westminster Press, 1970), 106, 112-118.

${ }^{107}$ Childs, Biblical Theology, 77. It does seem that Childs is protecting the witness of the OT from the tradition-historical tactics of scholars such as Gese who understand Scripture as a unified, unbroken continuity, thus dissolving the OT of its own unique character. Also, Childs rejects Hübner's thesis that it is only the OT as it is received by the New which is authoritative for Christian reflection. This is again seen as a threat to the integrity of the OT. This theological and intellectual climate sets the backdrop for much of Childs's development.

${ }^{108}$ Childs, Biblical Theology, 77.

${ }^{109}$ Childs, Biblical Theology, 78.

${ }^{110}$ Childs, Biblical Theology, 78.

${ }^{111}$ Childs, Biblical Theology, 83.
} 
itself to historical questions. Both description and the content of the witness are not two distinct stages, "but two parts of the one enterprise which remain dialogically related." ${ }^{\prime 12}$ Childs applies these two categories to Paul's exegesis of the OT. If an interpreter understands the exegetical task as merely erklären, Paul's OT interpretation will be nothing other than a misconstrual. If, on the other hand, an interpreter understands the necessity of conjoining erklären and verstehen, Paul's interpretation of the OT may be understood as a true rendering of the text's referent. ${ }^{113}$ This does not necessarily resolve all of the difficulties, but it does place the discussion of this issue in a more theological context.

Also, Childs clarifies his concern about identifying Paul's method of OT interpretation with biblical theology. "The reason behind this resistance is that such a move usually assumes that the original meaning of the Old Testament has lost its theological significance in the light of the New Testament, and that Paul's rendering of the Old Testament presents the one true sense of the text." ${ }^{114}$ It is the flattening of the OT witness itself that concerns Childs. Paul's reading of the OT is a true theological reflection of the witness of the text in light of its subject matter; however, Paul's reflection is not the only reflection needed and the OT continues in a canonical function that presses beyond Paul. That a relationship exists between Paul and later theological reflection is true. That Paul's reflection on the OT is the only reflection needed runs the risk of flattening the OT witness of its continuing discrete voice in the divine economy.

Is Paul's reading of the OT in light of God's action in Jesus Christ (and all that entails) coupled with the analogous Christian reading of a two-testament canon under the same rubric a blatant disregard for the literal sense of Scripture? Childs answers this question, "In other words, there is a legitimate place for a move from a fully developed Christian theological reflection back to the biblical texts of both testaments." 115 Childs concludes, "Such a reading is not intended to threaten the sensus literalis of the text, but to extend through figuration a reality which has been

\footnotetext{
${ }^{112}$ Childs, Biblical Theology, 83.

${ }^{113}$ Childs, Biblical Theology, 84. Childs (Biblical Theology, 87) asks the penetrating question, due to unnerve modern exegetical sensibilities, about the role of "reverse direction" exegesis that moves from the reality of the subject matter back to the biblical text. Childs affirms this move as legitimate form of hearing the full two-testament canon as Christian scripture "in the light of the full reality of God in Jesus Christ."

${ }_{114}$ Childs, Biblical Theology, 87.

${ }^{115}$ Childs, Biblical Theology, 87.
} 
only partially heard (emphasis mine)." ${ }^{, 116}$ For Childs, Paul's reading and later Christian reading is not to be understood as an obliteration of the literal sense of the text but is placed within a theological category of reading where the literal sense and the figural sense are not divorced but brought together in a dynamic and organic relationship under the true subject matter of Scripture, Jesus Christ. This larger theological landscape provides categories by which we may better understand Paul's theological reading of the OT as text and witness to Jesus Christ.

In a recently published dissertation, Childs has been appreciatively critiqued by Paul R. Noble. ${ }^{117}$ Though it is beyond the scope of the present work to interact with Noble on every front, it will be important to examine one of Noble's critiques of Childs, namely, Childs's constructive work on Paul and the OT. ${ }^{118}$ Noble finds the distinction drawn by Childs between modern historical-critical concerns and the concerns of Paul as "largely missing the point." "19 For Childs, according to Noble, the quest for meaning in modern historical-critical terms centered on the discovery of the text's true historical context and ostensive referent, whereas for Paul, the search for meaning in the OT centers on a different set of criteria. Paul's hermeneutical key is the witness bearing potential of the text to its true subject matter, Jesus Christ. ${ }^{120}$ It is in this discussion that Noble finds Childs unhelpful because Childs has misunderstood the rationale behind historical-critical concerns. Noble does not believe that the quest for understanding the original (or intentional) context is "merely a modern prejudice."" "Rather, it is an essential precondition for understanding the meaning of the text."122 One wonders whether or not Childs has really misunderstood the historical-critical presupposition stated by Noble. Surely, Childs would agree that this is the driving principle of modern sensibilities and would subsequently say that meaning for Paul is taking place on a different level of discourse and inquiry. Noble does not believe Childs has helped us forward in biblical theology if he has not

\footnotetext{
${ }^{116}$ Childs, Biblical Theology, 87. Childs continues to speak of the necessary and important role allegory and typology have in Christian interpretation. Also, the language of "figural extension" is similar to the language used of Dawson, Christian Figural Reading. To this we will return shortly. ${ }^{117}$ Paul R. Noble, The Canonical Approach: A Critical Reconstruction of the Hermeneutics of Brevard S. Childs (BIS 16; Leiden: Brill, 1995).

${ }^{118}$ Noble, The Canonical Approach, 302-306.

${ }^{119}$ Noble, The Canonical Approach, 304.

${ }^{120}$ Childs, Biblical Theology, 241.

${ }^{121}$ Noble, The Canonical Approach, 304.

${ }^{122}$ Noble, The Canonical Approach, 304.
} 
demonstrated that Paul really heard the OT and was not merely imposing his own readings on the text. ${ }^{123}$

Noble's criticisms of Childs's view of Paul and the OT do betray his own modernistic sensibilities. Noble fails to take into account that Childs's conjoining of text and reality does not necessitate the obliteration of the original context but is rather a legitimate extension of that text as figurally received by Paul. The "original context" of the text is brought into a new eschatological context, that is, a new canonical context. Paul's reading is taking place in an eschatological/theological sphere where meaning is not merely defined by historical reference but by its placement in God's divine economy. It should be stressed that a different set of questions and criteria than those posed by modern readings are being deployed by Paul. Meaning for Paul is not an historical "what did it mean," though without doubt Paul most likely assumed the historical veracity of the texts. Meaning for Paul is more dynamically related in the eschatological moment as both sign and reality are brought together. The OT text is the living voice of God and as such speaks of God's realities in the present moment. The text, theologically, is not merely an artifact of the past but an organism of the present. This is indeed a different set of criteria than those adopted by modern sensibilities, and without doubt, this is the front on which Childs is fighting. The present moment is an eschatological moment for Paul, with the subsequent implication that the true subject matter of Scripture has been revealed by God in Christ. Thus, the true meaning of the text is understood in this eschatological/theological locale. ${ }^{124}$

\footnotetext{
${ }^{123}$ Noble, The Canonical Approach, 305. In this very light, Noble (The Canonical Approach, 305) believes Childs to have serious shortcomings if Paul's principles of reading cannot be adopted by modern readers. Again, Childs's argument against the simple appropriation of Paul's reading for modern reading is a tight argument that needs to be set in context. Childs is not dismissing Paul's reading as a mis-reading, neither is he saying that no analogy exists between Paul's reading and later biblical theological reflection. Positively, Childs is asserting that biblical theology is a Christian reflection on two testaments which places modern readers in a different context than Paul. Also, Childs is concerned to protect the OT, and its potential for figural reading, from a flattening effect of saying we only read the way Paul read, e.g, the akedah of Genesis 22 can only be understood by Rom 8:32. Is there an analogical relationship between Paul and modern readers, yes; is there a univocal relationship between Paul and modern readers, no. This distinction seems to be missed by Noble. See also n. 5 .

${ }_{124}$ On the development of the literal sense to the historical sense more narrowly defined, see Hans Frei, The Eclipse of Biblical Narrative (New Haven: Yale University Press, 1974); see also Neil B. MacDonald, "Illocutionary Stance in Hans Frei's The Eclipse of Biblical Narrative" in After Pentecost: Language and Biblical Interpretation (Scripture and Hermeneutics Series, vol. II;ed. C. Bartholomew, C. Greene, K. Möller; Grand Rapids: Zondervan, 2001), 312-328, Karl Barth and the Strange New World within the Bible: Barth, Wittgenstein, and the Metadilemmas of the Enlightenment, (Carlisle: Paternoster Press, 2000).
} 


\section{Conclusion}

The purpose of this chapter is to set the larger landscape of the issues related to Paul's reading of the OT and hint at the theological conclusions to be drawn out in the final chapter. Each of the issues presented in cursory form is a monograph unto itself and the task of this dissertation is a rather modest one related to one particular text and the way in which that text ( 2 Cor 5:14-6:10) is informed by our reading of Isaiah 40-66 in its final canonical form and vice versa. ${ }^{125}$ Though theological conclusions will be drawn from this at the end of the thesis, these theological thoughts will only be penultimate because the focus of this inquiry is quite narrow, namely, Paul and Isaiah and only one passage within Paul and Isaiah. Whether or not the theological framework holds for other instances of Paul's reading of the OT will have to wait for another day. ${ }^{126}$ As has been stated, this thesis is not primarily text-critical. Rather, the conceptual overlap of key themes between Isaiah and Paul will be observed. In this regard, unless noted otherwise, questions of Paul's particular Vorlage are not as pressing. What is pressing are the implications of Isaiah's larger message, a message that for Paul is read in an eschatological context of God's redemptive action in Christ (the conjoining of erklären and verstehen), for Paul's own understanding of Christ's significance and Paul's placement in that eschatologically realized message. In other words, in what way does Isaiah's canonical voice, though read in a particular eschatological context, exert a pressure on Paul's theology in 2 Cor. 5:14-6:10?

Though Paul's reading of the OT may be defined by modern standards as eisegesis and not exegesis, Brevard Childs warns against this too hasty description of Paul. ${ }^{127}$ For Paul, Jesus Christ is the interpretive center of Scripture and as such, genuine interpretation depends on Scripture's bearing witness to Jesus Christ.

\footnotetext{
${ }^{125}$ This final canonical form includes the narrative movement the text takes in the large theological contours of the book, namely, the move from a focus on the Servant to the servants of the Servant in Isaiah 40-66.

${ }^{126}$ Though this author does believe that a theological approach to Paul's reading of the OT will yield the most abundant fruit in this type of inquiry. Express attention to other passages will not be given in this thesis.

${ }^{127}$ Brevard Childs, The Struggle to Understand Isaiah as Christian Scripture: A Hermeneutical Study (Grand Rapids: Eerdmans, 2004), 18.
} 
It is in this context that Paul seeks to listen faithfully to Scripture within a particular eschatological context that informs Paul's reading and goal of reading. Again, however, we are jumping ahead of ourselves. Our attention now turns specifically to 2 Corinthians. 


\section{CHAPTER TWO}

\section{PLACING THE EXEGETICAL/THEOLOGICAL ARGUMENT OF 2 CORINTHIANS 5:14-6:10}

\section{Introduction}

Within the Hauptbriefe of Paul, no extant letter reveals more autobiographical aspects of the Apostle than the canonical book 2 Corinthians. As the interpreter of Paul surveys the secondary literature of this letter a recurring theme emerges, a theme emphasized in the following statement of Furnish, "No Pauline letter requires more of its readers or offers more of a reward to those who apply themselves carefully to its interpreters than 2 Cor." 2 Corinthians is a book fraught with "problems," both literary and historical. How many letters are contained within the book? ${ }^{2}$ Who are the opponents against whom Paul is squared off? ${ }^{3}$ What historical circumstances led to

\footnotetext{
${ }^{1}$ Victor P. Furnish, The Anchor Bible: Il Corinthians (New York: Doubelday \& Company, 1984), 3. "It is generally held that of all Paul's letters II Corinthians is probably the most difficult to understand in detail." Johannes Munck, Paul and the Salvation of Mankind (London: SCM Press, 1959), 168. ${ }^{2}$ The arguments surrounding the literary integrity of 2 Corinthians are dense. In brief, most scholars recognize chapters 1-9 and 10-13 as distinct letters and within these letters redaction critics have found multiple fragments (e.g. within chapter 1-9, 2:14-7:4; 6:14-7:1; chapters 8 and 9). Debate also centers on whether chapters 10-13 compose the 'painful letter' Paul speaks of in 2 Cor 2:3-4. For detailed discussion regarding these issues see, Furnish, II Corinthians, 30; Margaret Thrall, II Corinthians, Vol. I. (ICC; Edinburgh: T\&T Clark, 1994), 13-47; Ralph P Martin, WBC: 2 Corinthians (Waco: Word Books, 1986), xxxviii-lii; J. Paul Sampley, "Second Corinthians" in NIB, Vol. XI (Nashville: Abingdon Press, 2000), 5-12. Lambrecht offers a helpful overview of the literary difficulties of 2 Corinthians in the following statements: 1) nothing in the text or in the MSS traditions betrays any lack of integrity; 2) those who assume that the letter is a post-pauline composite are forced to explain the hypothesis of how this letter came to be arranged and for what purpose (a task Lambrecht thinks difficult at best, impossible at worst); 3) modern interpreters may be inclined to require from Paul too much consistency. "After all," he says, "we are dealing with a letter, not a systematic expose." Lambrecht continues to remind the modern reader that we do not know how long it took Paul to compose his letter. Lambrecht concludes, "No break in the narrative or argument, no change in the vocabulary or tone appears to be so great that the parts could not have stood originally, one next to the other, in a single letter" (Sacra Pagina Series, Vol. 8: Second Corinthians, [Minnesota: The Liturgical Press, 1999], 9). The literary "problems" of 2 Corinthians are not necessarily unraveled by these comments; however, the "problems" are not so great for the modern interpreter that he or she cannot grasp the autobiographical and theological thrust of the present canonical form of the material.

${ }^{3}$ The positions held on the identity of the opponents are summarized by Schütz: 1) F.C. Baur argues that Paul's opponents were from the Jewish wing of the church connected with the apostle Peter. One notes Baur's Hegelian dialectic working in his assumption; 2) Käsemann recognizes the opponents as Palestinian Jewish-Christians slyly laying claim to the authority of the Jerusalem apostles; 3) Kummel places the opponents in a Palestinian setting yet not connected to the Jerusalem authorities. They were closely related to the Gnostics of 1 Cor; 4) Lutgert, Bultmann, and Schmithals observe the opponents as Jewish-Gnostic Spiritualist; 5) Georgi (Schütz sides with him) "places the opponents within a diffuse tradition of wandering preachers having pagan and Jewish representatives throughout the Hellenistic world. They are pneumatics within a Jewish missionary tradition which has been
} 
the composition of this letter/letters ${ }^{4}$ Do we need to follow the advice Furnish gives in the following statement: "Indeed, the student of 2 Cor quickly discovers that, particularly in this instance, biblical interpretation involves virtually in equal measure historical reconstruction, literary analysis, and a sensitivity to theological concerns" (emphasis mine). ${ }^{5}$

Historical-criticism has encouraged the interpreter of Scripture to establish the Sitz im Leben of the text before its meaning can be procured. Recent literary trends, however, place a greater emphasis on the Sitz im Text. ${ }^{6}$ Historical reconstruction, though an illuminating and essential aspect of exegesis, cannot be viewed as the hermeneutical key in the process of recovering or discovering meaning. ${ }^{7}$ The range of

appropriated by Christian circles. They wed a Christology of the divine man to their apostolic selfconsciousness" (Paul and the Anatomy of Apostolic Authority, [Cambridge: CUP, 1975], 167-168). C.K Barrett and Ralph P. Martin argue against Baur's position by placing the opponents in a Hellenistic context (siding for the most part with Georgi). Cf. Ralph P. Martin, "The Opponents of Paul in 2 Corinthians: An Old Issue Revisited," in Tradition and Interpretation in the New Testament: Festschrift E. Earle Ellis, ed. G. F Hawthorne and O. Betz, (Grand Rapids: Eerdmans, 1987), 282-287. The recent work of Jerry L. Sumney (Identifying Paul's Opponents: Question of Method in 2 Corinthians [JSNTS 40; Sheffield: Sheffield Academic Press, 1990]) offers a fresh appraisal of the opponents of Paul with an approach based on the text. Sumney warns against drawing hard and fast conclusions on the basis of parallels in the religions of the day (the religionsgeschichtliche approach). Extrinsic sources may be helpful but they cannot provide an exact identity. Hafemann, though approving of Sumney's method, challenges his conclusions, "However, when applied to 2 Corinthians, Sumney's own method offers no new insights into the identity of Paul's opponents....and his final conclusion concerning their identity on pp. 177-179, 184f., in which he agrees with the previous proposal of Käsemann concerning the opponents behind 2 Corinthians 10-13 as pneumatics, rather thant Judaizers, Gnostics, or Georgi's 'divine men' (Paul, Moses, and the History of Israel [WUNT 81; Tübingen: J.C.B. Mohr, 1995], 260). The historical-critical drive to establish this 'behind the text' issue is counseled by Lambrecht ( 2 Corinthians, 7$)$ in the following way, "Yet since Paul himself does not pay much attention to the religious origius and historical provenance of his opponents, identifying them may remain impossible. One could even ask whether this is really necessary in order to understand Paul's main concern." See Hafemann, Paul, Moses, 259-262. The key "opponents texts" of 2 Corinthians are $3: 1 ; 10: 11 ; 11: 2-5 ; 11: 6 ; 11: 7-12 ; 11: 13$.

${ }^{4}$ For a survey see Brevard Childs, The New Testament as Canon: An Interpretation (London: SCM, 1984), 282-296.

${ }^{5}$ Furnish, II Corinthians, 3.

${ }^{6} \mathrm{Hans}$ Frei, The Eclipse of Biblical Narrative: A Study in Eighteenth and Nineteenth Century Hermeneutics (New Haven: Yale Press, 1974).

${ }^{7}$ William Kurz has written a stimulating article pertaining to the canonical implications of reading 2 Corinthians ("2 Corinthians: Implied Readers and Canonical Implications," JSNT 62 [1996]: 43-63). In concert with David Trobisch (Paul's Letter Collection: Tracing the Origins [Minneapolis: Fortress Press, 1994]), Kurz questions the modern interpretation of 2 Corinthians with its never ending pursuit of the Sitz im Leben of the original letter. If 2 Corinthians is a composite letter, which Kurz assumes with the majority of scholars to be the case, the composite does not directly correspond to the original situation of the fragments. The canonical move of placing the fragments into a composite has already relativized, though maybe too strong of a word, the original Sitz im Leben for a larger canonical reading audience. This is the question that has been raised by the canonical approach: "What happens to the interpretation of a document when it is incorporated into a larger document or collection and read by later and different readers than those initially addressed by the individual document" (Kurz, "2 Corinthians," 46). Kurz posits that one recognizes this canonical reception, or broader implied readership, in Col 4:16, "And when this letter is read before you, have it read also in the church of the Laodiceans, and you yourselves read the one from Laodicea." Also, 2 Cor 1:1 addresses the letter not 
opinions on the historical and literary circumstances of 2 Corinthians, noted briefly in the footnotes below, are quite diverse with no consensus on the solution to these literary and historical "problems." Though Paul was interacting with a real church, with real opponents and circumstances, our understanding of those realities is textually mediated. Resultantly, privilege will be given to the apostolic voice in the text itself in its present canonical placement. ${ }^{8}$

\section{Paul's Main Theme in 2 Corinthians}

The reader familiar with the Pauline writings senses the unique nature of this letter. Paul's method of personal exposure and transparency is unlike any of his other extant letters. His sense of urgency and awkwardness is revealed in a simple reading as the Apostle's self-defense or self-apologetic is laid bare before the reader. Paul's selfdefense, however, is not merely a defense of the self but a defense of his apostolic office. Bultmann reflects on Jülicher's assessment of 2 Corinthians, "According to Jülicher (Einleitung, 87), 2 Corinthians is 'the most personal of the extant letters of Paul,' containing 'self-defense and polemic throughout.' Correct! But exegesis dare not allow itself to be misled into explaining the letter as an essentially biographical document or making its goal a portrait of Paul's personality, for Paul conceives his writing throughout as an apostolic writing...Paul's person is at issue only insofar as he is bearer of the apostolic office..."9

Thus, Young and Ford are on the right track when they assert that 2 Corinthians is concerned with two things, 1) the glory of God and 2) the reputation of Paul. ${ }^{10}$ Paul's defense of the self was not a defense of his reputation per se, but his reputation as an apostle of God. For Paul, a defense of the self was linked with a

only to the Corinthians but to the Christians in the region of Achaia. Kurz's exegetical conclusions on the basis of this thesis are not the strongest aspect of his article. I do not think they were intended to be. However, Kurz has raised the awareness for interpreters who base their exegetical conclusions on a reconstructed Sitz im Leben that the grounds of their historical aims may be ill-founded. If Kurz and Trobisch are right, what one finds in the canonical form of Paul's letter is an intended "reactualization" of texts by later readers (or Paul himself, e.g. Trobisch) to their own particular situations (Kurz, "2 Corinthians," 62). See also Brevard Childs, The New Testament as Canon: An Introduction (London: SCM Press, 1984).

${ }^{8}$ This is not to downplay the importance of background information such as social-history, Corinth in a Graeco-Roman world, etc. See Jerome Murphey-O'Connor's helpful insights into the world of Corinth in his New Testament Theology: The Theology of the Second Letter to the Corinthians (Cambridge: Cambridge University Press, 1991). From a canonical perspective, background information needs to remain background information that informs our reading of the texts and not the goal of the exegetical task. Again, see Childs, The New Testament as Canon, 274.

${ }^{9}$ Rudolf Bultmann, The Second Letter to the Corinthians (Minneapolis: Augsburg Press, 1985); Furnish, 2 Corinthians, 34; Lambrecht, Second Corinthians, 1. 


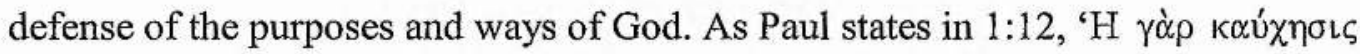

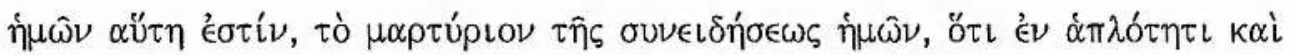

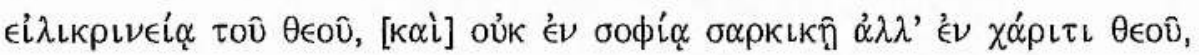

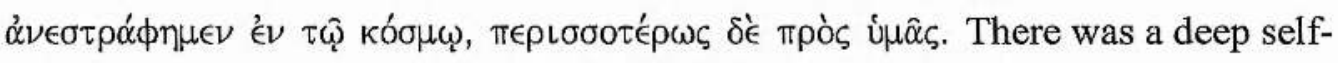
awareness in Paul of his dependence on the grace of God to carry out his apostolic office, and at the beginning of the letter Paul is drawing a sharp distinction between the "wisdom of the world" and the "grace of God," a theme that will continue throughout 2 Corinthians.

Scott J. Hafemann interacts with Käsemann's "Die Legitimität des Apostels," in which Käsemann argues "that, of all the accusations being leveled against him, Paul was especially being blamed for his supposed 'Selbstlob'."11 It was Paul's weakness that called into question his apostolic authority, a fact Paul's debunkers were happy to point out (cf. 11:1ff). Käsemann places Paul in the middle of an argument with certain opponents who are challenging his apostolic authority; however, Paul decides "to [reestablish] the rules of the game." 12 The rules of the game Paul allows as worthy criterion are not based on worldly wisdom but on the wisdom of God $(1: 12 ; 2: 17 ; 5: 16 ; 10: 5)$.

Hafemann continues in his article to draw the natural conclusions from Käsemann's thesis that this reading of Paul presents the interpreter with "a serious problem." "13 Apparently, Paul is speaking out of two sides of his mouth. On the one hand, Paul affirms the necessity of spiritual discernment of the non-objective sort as "evidence" (1:12), yet, on the other hand, he begins to give objective, controllable data as support of his apostolic office $(6: 4-10 ; 11-12)$. "Thus, in addition to the

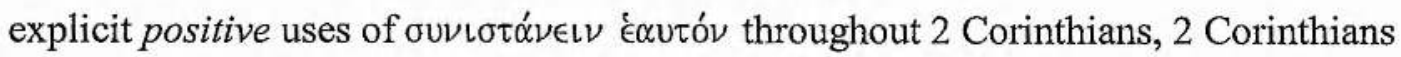
itself becomes a self-commendation despite Paul's equally explicit rejection of allegations that he engages in such practices." ${ }^{14}$ Hafemann then takes the reader on a journey through 2 Corinthians seeking to sort out this "apparent contradiction" of Paul's self-commendation, which Hafemann takes as the central theme of the book. ${ }^{15}$

\footnotetext{
${ }^{10}$ Young and Ford, Meaning and Truth, 12.

${ }^{11}$ Scott Hafemann, " 'Self-Commendation' and Apostolic Legitimacy in 2 Corinthians: A Pauline Dialectic?" NTS 36 (1990): 66-88, 66. op. cit. E. Käsemann, "Die Legitimität des Apostels. Eine Untersuchung zu II Korinther 10-13,“ $Z N W 41$ (1942): 33-71, 36.

${ }^{12}$ Hafemann, "Self Commendation," 66.

${ }^{13}$ Hafemann, "Self-Commendation," 67.

${ }^{14}$ Hafemann, "Self-Commendation," 71.

${ }^{15}$ Hafemann, "Self-Commendation," 70.
} 
Having observed the tension of Paul's self-commendation in 2 Corinthians, Hafemann asserts that 2 Cor 10:18 is the "crux interpretum" for understanding Paul's apologetic. ${ }^{16}$ The validity of Paul's boasting rests on the criterion of his

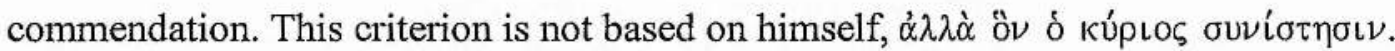
Paul parts company with his opponents not on the basis of "self-commendation" or "self-substantiation," rather, as Hafemann observes, "the criterion they are using to establish their apostolic ministry in Corinth is irrelevant." 17 The opponents of Paul commend themselves on the basis of their own self-achievements; Paul's basis for self-commendation is his approval by the Lord (10:18). The commendation carrying apostolic validity is the one based on the Lord, not the self.

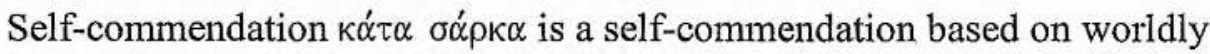
standards. Entering the world of 2 Corinthians, the reader is struck by the fact that the source of legitimacy and warrant for Paul's apostolic authority is not based on those categories valued by Paul's opponents (impressive speech and the like, 11:5-6) but are based on the categories of a servant of God. When Paul is forced to prove his apostolic claim and authority, he reveals the very thing that has brought him into disrepute, his suffering and his weakness $(2: 14-17 ; 10-13)$. The driving force of Paul's argument in 2 Corinthians is his apostolic self-defense in light of his own suffering and commendation by God as exemplified in Paul's following of Jesus Christ. ${ }^{18}$

\section{Paul's Warrant for Suffering}

Having observed Paul's defense of his apostolic integrity as the main theme of 2 Corinthians, one would be correct to ask the following question: "What warrant does Paul give to support his case?"19 Paul's argument in 2 Corinthians is motivated in some measure by the doubt of the Corinthian believers. ${ }^{20}$ Therefore, Paul is working

\footnotetext{
${ }^{16}$ Hafemann, "Self-Commendation," 74.

${ }^{17}$ Hafemann, "Self-Commendation." 77.

18 "What appears weak, contemptible, sinful (10:10; cf. 5:21) and 11:7), transient (4:18) or false to human eyes and minds is not necessarily so in God's sight; and what finally matters is reality as God sees it." David M. Hay, "The Shaping of Theology in 2 Corinthians: Conviction, Doubts, and Warrants," in Pauline Theology: Vol. 2, ed. D. M. Hay, (Minnesota: Fortress Press, 1993), 141.

${ }^{19}$ David Hay ("The Shaping," 138) suggests this definition of warrant when dealing with 2 Corinthians, "As I will use the term, "warrant refers to any explicitly stated basis for an argument or appeal. A warrant is a stepping-stone by which the apostle seeks to transport his readers from uncertainty or doubt regarding some issue to a position of conviction."

${ }^{20}$ Gaventa is not persuaded by Hay's use of the term 'doubt' in 2 Corinthians to describe the conceptual category of the Corinthian church towards Paul. She prefers the term "misunderstanding." "What is at stake in 2 Corinthians has less to do with doubt than it does with competing understandings of what God has accomplished in the death and resurrection of Jesus Christ and what implications that
} 
toward the goal of persuasion within this letter. Simply stated, Paul is seeking to bring the Corinthians from the realm of doubt and mistrust to belief and mutual affection. The climax of the literary unit of 2:14-7:4 poses no surprise at Paul's most personal of

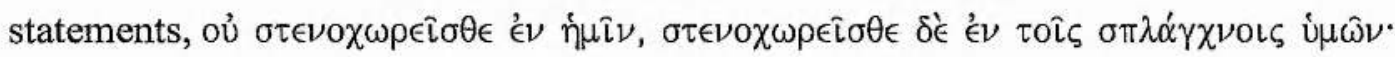

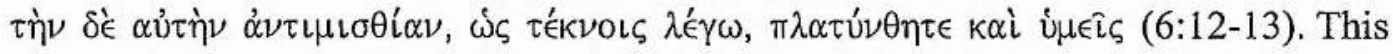
desire for mutual trust and affection is the telos toward which Paul is moving. Paul

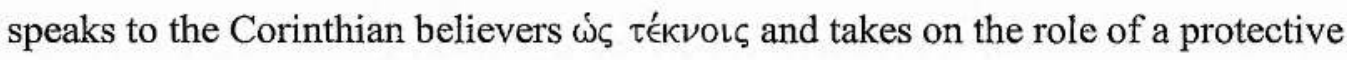
father (11:1-3).

Regarding Paul's choice weapons in his self-defense, David Hay lists the

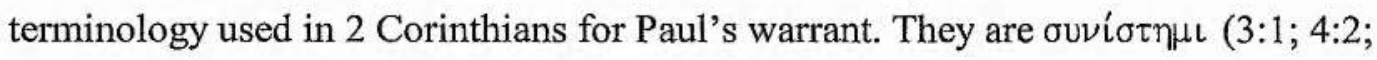

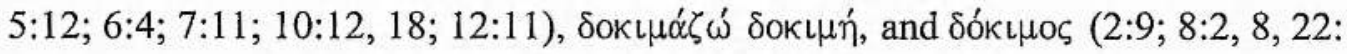
$9: 13 ; 10: 18 ; 13: 3,5,7){ }^{21}$ The categories of warrant Paul appeals to are variegated. Hay categorizes Paul's tool-bag of warrant as 1) kerygmatic, or that pertaining especially to Christ; 2) scriptural quotations and allusions; 3) Paul's own apostolic authority and conduct; and 4) the Spirit and the Corinthian experience. ${ }^{22}$ Hay's category of kerygmatic, or that which belongs to Christ, takes a central role in Paul's apostolic self-defense. One should be reminded, however, that these categories often overlap with one another and are not mutually exclusive.

Our purpose is not to explore every type of warrant Paul uses in his arsenal of self-defense. The boundaries of this particular task are marked by Paul's use of the Scriptures as warrant. Interestingly enough, 2 Corinthians pales in comparison to the other letters of Paul's Hauptbriefe regarding number of Scripture citations. Paul's direct citation of Scripture is found in $4: 13 ; 6: 2,16-18 ; 8: 15 ; 9: 9$. The first three citations are found within the literary unit of $2: 14-7: 4$, and the latter two are located in the midst of Paul's discourse on giving. It would be a superficial judgment to discount the use of Scripture in 2 Corinthians on the basis of scant citation formulae. Ford and Young state, "Paul is illuminated by the observation that he has 'lived in the Bible' to the point where the Bible has formed his whole outlook on how the world is and what

\footnotetext{
death and resurrection have for the way in which human beings understand God, themselves, and one another" ("Apostle and Church in 2 Corinthians," in Pauline Theology, Vol. II [Minneapolis: Fortress Press, 1993], 186-187). The distinction between doubt and misunderstanding need not be pressed too hard. The conceptual issue at hand is the Corinthian lack of confidence in Paul's apostolic status. This can be construed as doubt and misunderstanding as overlapping categories.

${ }^{21}$ Hay, "The Shaping" 150.

${ }^{22}$ Hay, "The Shaping," 150.
} 
his place in it might be." 23 "Living in the Bible" is an apt comment for the Paul we find in 2 Corinthians, especially the Paul of 2:14-7:4. Paul's discourse in chapter 3 takes seriously the authoritative validity of the Mosaic account in Exodus. Chapter 4 resonates with creation imagery as found in Isaiah coupled with a quotation from the Psalter, and chapter 5:14-6:18 is riddled with OT allusion, which we will come to in due course. For now, it should suffice to say that for Paul, Scripture plays a major, if not leading, role in his self-apologetic in 2 Cor 2:14-7:1.

Though commenting on Romans, N.T. Wright is correct in his proposal that Paul's quotation of the OT Scripture, especially Isaiah, reflects deep meditation on the passage as well as the context. ${ }^{24}$ This makes the task for the interpreter difficult. As mentioned in the first chapter, quotations are easier to quantify and categorize. Allusion and echo, on the other hand, are slippery and subjective to a degree. ${ }^{25}$ What resonates in the ear of one interpreter may not resound as loudly in the ear of another. Also, the allusion, or echo, raises the stakes for the ways in which Paul reflects on and uses Scripture. An allusion can give the idea that Paul is using Scripture in that particular instance in an ad hoc fashion or as a throw-away comment. One should be careful in characterizing Paul's appeal to Scripture in this manner. ${ }^{26}$ Deep reflection on the message of Isaiah 40-66 in it own canonical form and shape is demonstrated in Paul's thought, as will be shown. Hafemann states, "It is surprising, however, how quickly NT exegetes presume to understand precisely how Paul used and misused (!) his OT source without first examining the source itself carefully."27 This study will seek to honor Hafemann's concerns regarding the necessity of examining the OT material itself.

\footnotetext{
${ }^{23}$ Frances Young and David Ford, Meaning and Truth in 2 Corinthians (London: SPCK, 1987), 63.

${ }^{24}$ N. T. Wright, "Romans and the Theology of Paul," in Pauline Theology, Vol. III (ed. D. M. Hay and E. E. Johnson; Minneapolis: Fortress Press, 1995), 58. More recently, J. Ross Wagner, "The Heralds of Isaiah and the Mission of Paul" in the Jesus and the Suffering Servant: Isaiah 53 and Christian Origins (ed. W. Bellinger, Jr. and W. R. Farmer; Harrisburg: Trinity International Press, 1998), 294. Dodd's thesis that the NT authors took into account the context of the their OT quotations is an early predecessor of Wright's claim (C.H. Dodd, According to the Scriptures: The Substructure of New Testament Theology [London: Nisbet \& Co, 1953]). See Childs's critique, via Lindars, of Dodd's emphasis of the concept of history as the unifying force rather than the text themselves (Biblical Theology, 228).

${ }^{25}$ Richard Hays, Echoes of Scripture in the Letters of Paul (New Haven: Yale Press, 1988).

${ }^{26}$ Moisés Silva, "The New Testament Use of the Old Testament: Text Form and Authority," in Scripture and Truth (ed. D.A. Carson and J.D. Woodbridge; Grand Rapids: Baker, 1998), 147-161.

${ }^{27}$ Hafemann, Paul, Moses, 189.
} 
Paul is a theologian whose world had been de-centered by the Christ. ${ }^{28}$ For Paul, the person and work of Jesus Christ demonstrates that God has entered the world of man to redeem him (5:18) and this hope is the fulfillment of all the promises God had given (1:19-20). In short, Jesus is God's eschatological "yes." We should not be surprised to find Paul, Jew of Jews, turning to the Scriptures of Israel to provide warrant for both God's activity in Jesus and warrant for Paul's role in this redemptive drama. ${ }^{29}$ And we should not be surprised to find Paul's exegetical starting point to be a theological one determined by God's eschatological action in Christ. Before turning our attention directly to the passage at hand (5:14-6:13), a brief investigation into Paul's use of Scripture in 2 Corinthians 3 will serve to bolster the argument that Paul has reflected deeply on the Old Testament in the midst of his apostolic self-defense in 2:14-7:1.

\section{3. a Scripture in 2 Corinthians 3}

2 Corinthians 3 is a crucial passage in one's understanding of Paul and Scripture in 2 Corinthians. Paul's underlying argument within this literary unit is based on Scriptural referent and allusion. Chapter 3 has proven itself to be an exegetical battleground for interpreters of Paul. The key issues in the interpretation of chapter 3 have been the relationship between $\gamma \rho \alpha \mu \mu \alpha$ and $\pi \nu \in \nu \mu \alpha$ in 3:6 coupled with Paul's view of the Mosaic covenant or the Law. The purpose at this point is not to enter into the debate with the various interlocutors on this complex subject. ${ }^{30}$ What should be noted, however, is Paul's use of the Mosaic tradition in Exodus 32-34 as normative support for his claims. We do not find Paul proof-texting his way through the argument, but thinking deeply on the larger narrative structure and significance of the Mosaic story of Exodus 32-34. ${ }^{31}$

Hafemann's illuminating work on 2 Corinthians 3 is a demonstration of a NT scholar seeking to do justice to the original narrative structure of the Exodus tradition.

\footnotetext{
${ }^{28}$ Stephen Fowl, "Learning to Narrate our Lives in Christ," in Theological Exegesis: Essays in Honor of Brevard S. Childs (ed. C. Seitz and K. Greene-McCreight; Grand Rapids: Eerdmans, 1999), 339-354.

29 " 2 Corinthians indeed offers a very considerable number of scriptural allusions and quotation, often presented as unquestionable warrants for the conclusions Paul seeks to draw" (Hay, "The Shaping," 151).

${ }^{30}$ See Hafemann, Paul, Moses; L.L. Belleville, Reflections of Glory. Paul's Polemical Use of the Moses-Doxa Tradition in 2 Cor 3, 1-18 (JSNTSS 52; Sheffield: Sheffield Academic Press, 1991); N.T Wright, "Reflected Glory: 2 Corinthians 3:18" in The Climax of the Covenant (Minneapolis: Fortress Press, 1993), 175-192. See also the interlocution between Hays and Dawson in chapter one.

${ }^{31}$ Hafemann, Paul, Moses, 191-195.
} 
Though Paul is working within a "pre-critical" framework in his use of Exodus [i.e. Paul assumes a literary unity with no distinction between the literal meaning and its historical referent], we do not find Paul manipulating the Mosaic narrative. Rather, he is faithful to its canonical form. Paul uses the text typologically or 'figurally,' but this does not necessitate a destruction of the text's "plain sense." Hafemann refers to Frei in the following way, "For as Frei has pointed out, a 'figural' or typological reading of the biblical narrative, which we certainly have in part in 2 Corinthians 3 (cf. 4:14), depends for its very existence and credibility upon a prior literal reading of the story."32

In my view, what Hafemann has shown, apart from the methodological conclusions he derives from Paul's use of the OT, is that Paul has reflected deeply on the narrative structure of Exodus 32-34 and transported his reflections into the argument of 2 Corinthians 3. "Finally, it must be recognized that for Paul, Exodus 3234 is not simply a story, but a biblical narrative. This means, above all, that the interpreter must be alert to the theological intention and significance of the story."33 For Paul the theological sense, or the figural sense, is not dichotomized from the plain sense. ${ }^{34}$ In fact, the biblical narrative continues to speak into Paul's current situation via the vehicle of the material witness itself. Pertinent to this project is not Hafemann's detailed exposition of the various exegetical and theological issues pertaining to 2 Corinthians 3 or the scholarly debates that center on these issues (though his arguments on this score are found to be quite salient). Rather, what is received is a programmatic framework for the ways in which Paul took seriously the biblical record itself as a witness beyond itself to God's activity in Christ. The Exodus narrative is a biblical narrative with abiding theological significance in the flow of God's providential ordering of history and as such, continues to exert a certain amount of pressure on Paul's theological discourse and reflection. ${ }^{35}$ With this in mind, our attention now turns to the specifics of the passage at hand.

\footnotetext{
${ }^{32}$ Hafemann, Paul, Moses, 192.

${ }^{33}$ Hafemann, Paul, Moses, 194.

${ }^{34}$ This statement will be explored more fully in chapter 5 .
} 


\section{The Background of 2 Corinthians 5:11-6:10 in Recent Discussion}

Recent discussion on the background of 2 Cor 5:11-7:1 has centered on several issues:

1) What is the background for Paul's use of the term $\kappa \alpha \tau \alpha \lambda \lambda \alpha \alpha^{\prime} \sigma \sigma \omega$ ? 2) Is there an OT background to 5:21 - sacrificial imagery or not? 3) What is Paul doing with Isaiah in 2 Cor $6: 2$ ? 4) What is the background for 6:14-7:1? Admittedly, the dialogue-partners who have given detailed attention to the background or substructure of this section of Paul are few. I wish to enter the dialogue and argue that within 5:11-6:10, the textual boundaries of this thesis, Paul is using the redemptive drama of Isaiah 40-66 as warrant for his own apostolic suffering and authority.

Marvin Pate's monograph on the substructure of 2 Cor 4:7-5:21 describes contemporary, Jewish, Adam theology as the background of Paul's discourse. ${ }^{36}$ The concepts holding together this unit are "glory" and "suffering" in which "the lost glory of Adam has been restored by Christ, the last Adam's righteous suffering.",37 Admittedly, Pate's major exegetical concern is the background of 2 Cor 5:1-10, an elusive passage for scholars. Is Paul drawing on Hellenistic ideals (R. H. Charles and W. L. Knox)? Or is Paul strictly working within the eschatological framework of Judaism (Schweitzer, Vos, Cullmann, Jeremias, Ridderbos)? Possibly Paul is combining Judaism and Hellenism (W. D. Davies, A. Lincoln)? Pate's resolution to the dilemma is to place not only 5:1-10 but 4:7-5:21 against the backdrop of Paul's Adam Christology. ${ }^{38}$

Pate examines the major literature of the Second Temple period, including documents from Qumran, Wisdom literature, Apocalyptic Judaism, and Rabbinic materials beyond the Second Temple period to demonstrate two aspects of Adam theology. "First, the primeval glory that Adam lost because of his sin will be restored to the righteous in the world to come. Second, that restoration will occur because the righteous presently suffer.",39

Though an illuminating read on the aspects of Adam theology in Second Temple Judaism and Rabbinic theology, the appeal to Adam Christology as the substructure of Paul's thought in this discourse is not found persuasive. Aside from

\footnotetext{
${ }^{35}$ Within the canonical form of 2 Corinthians, $2: 14-7: 1$ stands as a literary unit. Scholars are univocal on this score. Though recognizing the canonical shape of 2 Corinthians as a whole, this monograph will work, for the most part, within the confines of this literary unit.

${ }^{36}$ Marvin C. Pate, Adam Christology as the Exegetical \& Theological Substructure of 2 Corinthians 4:7-5:21 (Lanham: University Press of America, 1991).

${ }^{37}$ Pate, Adam Christology, 1.

${ }^{38}$ Pate, Adam Christology, 4-23.
} 
the difficulties associated with the study of Second Temple Judaism with its variegated aspects covering close to 500 years, coupled with the slippery ground of the relationship between Rabbinic Theology and Second Temple Judaism, there seems no compelling textual evidence to support the claim that Paul is dealing with Adam theology as a warrant for his own righteous suffering. ${ }^{40}$ Also, though Pate alludes to the OT throughout his work, he does not seem to take into account the significance of the OT for Paul. Thus, one is left with Paul more reliant on contemporary Jewish Adamic theology than the Scriptures of Israel. This is not to exclude the possibility that Adam theology was a part of Paul's thought in general, obviously it was (cf. 1 Corinthians 15 and Rom 5:12). Therefore, it should not be necessarily ruled out that Paul may have had Adam motifs in mind in 2 Cor 5:14, though this is not found convincing. ${ }^{41}$ It is suggested, however, that if one is going to seek to understand the substructure of Paul's thought in this passage, one's clues must be textually mediated; and within this text there seems to be no reason to assume Adam theology as the background to the entire unit.

Other than Pate, the main dialogue partners on background or substructure of our unit are Seyoon Kim, Otfried Hofius, Greg Beale, and William Webb. ${ }^{42}$ Seyoon Kim's major contribution to Pauline studies has centered on questions pertaining to

\footnotetext{
${ }^{39}$ Pate, Adam Christology, 33-34.

${ }^{40}$ James C. VanderKam, An Introduction to Early Judaism (Grand Rapids: Eerdmans, 2001); Justification and Variegated Nomism: The Complexities of Second Temple Judaism (ed. D. A. Carson, P. T O'Brien, M. Seifrid; Grand Rapids: Baker, 2002); Mark Adam Elliot, The Survivors of Israel (Grand Rapids: Eerdmans, 2000). Pate affirms Isaianic allusions in 2 Cor 5:14-21. The suffering servant motif is a part of Paul's thought process coupled with Adam theology in the background (Pate, Adam Christology, 142-143). Within Pate's work one is led to read Isaiah in light of Jewish Adam theology. One wonders whether, from a Pauline perspective, Adam theology (if it is present in this text) should be a subset of our reading of Isaiah and not vice-verse. This seems affirmed textually by Paul's quotation of Isa 49:8 in 2 Cor 6:2.

${ }^{41}$ Jon R. Levision has debunked the over-emphasis of "Adam Christology" in Pauline thought in his Portraits of Adam in Early Judaism: From Sirach to 2 Baruch (JSPS 1; Sheffield: Sheffield Academic Press, 1988), a work surprisingly absent from Pate's 1991 published thesis. Levison's (Portraits of Adam, 13) thesis is "the 'motifs' of an 'Adam speculation' or 'Adam myth' which the last generation of scholars discerned in Early Judaism do not exist." Levison's work, without doubt, calls into question

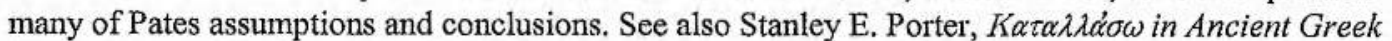
Literature, with Reference to the Pauline Writings (Cordoba: Ediciones El Almendro, 1994), 139. ${ }^{42}$ Seyoon Kim, " 2 Corinthians 5:11-21 and the Origin of Paul's Concept of Reconciliation," in Paul and the New Perspective: Second Thoughts on the Origins of Paul's Gospel (Grand Rapids: Eerdmans, 2002), 214-238; Otfried Hofius, "Erwägungen zur Gestalt und Herkunft des paulinischen

Versöhnungsgedankens," in Paulusstudien (WUNT 51; Tübingen: J. C. B. Mohr, 1989), 1-14; G. K. Beale, "The Old Testament Background of Reconciliation in 2 Corinthians 5-7 and Its Bearing on the Literary Problem of 2 Corinthians 6:14-7:1" in NTS 35 (1989): 550-581, reprinted in The Right Doctrine from the Wrong Text: Essays on the Use of the Old Testament in the New (ed. G. K. Beale, Grand Rapids: Baker, 1994), 217-247. My pagination will correspond to the latter. William J. Webb, Returning Home: New Covenant and Second Exodus as the Context for 2 Corinthians 6.14-7.1 (JSNTS 85; Sheffield: Sheffield Academic Press, 1993).
} 
the origin of Paul's gospel. ${ }^{43}$ Kim's doctoral dissertation presents the thesis that "reconciliation" for Paul originated in his own Damascus experience, and 2 Cor 5:1121 serves as the exegetical test-case to prove Kim's thesis. ${ }^{44} \mathrm{Kim}$ denies any "prePauline fragment" as a part of this pericope and after reviewing the relevant research on the linguistic background of the term "reconciliation" concludes 1) "that the $\kappa \alpha \tau \alpha \lambda \lambda \alpha \sigma_{\sigma} \sigma \in \mathrm{L} \nu$-terminology is uniquely Pauline within the New Testament" and 2) that the Pauline usage of the terminology represents a real innovation in Religionsgeschichte. ${ }^{45} \mathrm{Kim}$ 's conclusions are connected to the actual use of the term $\kappa \alpha \tau \alpha \lambda \lambda \alpha$ $\sigma \sigma \omega$, a strictly Pauline term in the NT, not the conceptual framework connected to this particular lexeme.

In his work; Kim interacts with differing positions of origin. Kim agrees with Goppelt's emphasis on the significance of the "Jesus-tradition" for Paul but dismisses this framework as an inappropriate answer to the source-question of Paul's terminology. ${ }^{46}$ Hofius posits that Paul's "reconciliation" language finds its origin in the fourth Servant song of Isaiah (Isa 52:13-53:12). The point of similarity between the fourth Servant song of Isaiah and the term "reconciliation" is the "peace" given to those made righteous by the Suffering Servant. ${ }^{47} \mathrm{Kim}$ find this connecting term, "peace," to be a rather thin argument for the origin of Paul's use of $\kappa \alpha \tau \alpha \lambda \lambda \alpha \alpha \sigma \sigma \in \mathrm{L} /$ $\kappa \alpha \tau \alpha \lambda \lambda \alpha$ ' $\eta \eta^{48}$ I. H. Marshall suggests that "Jewish martyr" traditions as found in 2 Maccabees may serve as background. Kim does not think Marshall's thought does justice to the concept of Paul as $\delta\llcorner\alpha \kappa o \nu\llcorner\alpha \dot{\alpha} \tau \hat{\uparrow} \varsigma \kappa \alpha \tau \alpha \lambda \lambda \alpha \gamma \eta \hat{\varsigma}$ (2 Cor 5:18), and Bieringer's suggestion that the conflict between Paul and the Corinthians serves as the occasion for Paul's use of $\kappa \alpha \tau \alpha \lambda \lambda \alpha \dot{\sigma} \sigma \sigma \omega$ is dismissed as beyond the context of Paul's statement. ${ }^{49}$ Kim concludes his survey by stating that these different optionsprimitive Christian confession, Jesus-tradition, the fourth Servant Song, the Hellenistic Jewish tradition represented in 2 Maccabees, or the Hellenistic diplomatic terminology of reconciliation - "may be seen as reflected, none of them can be claimed as the decisive catalyst for its development."

\footnotetext{
${ }^{43}$ Seyonn Kim, The Origins of Paul's Gospel (Grand Rapids: Eerdmans, 1982).

${ }^{44} \mathrm{Kim}$, Paul and the New Perspective, 214.

${ }^{45} \mathrm{Kim}$, Paul and the New Perspective, 218.

${ }^{46} \mathrm{Kim}$, Paul and the New Perspective, 218.

${ }^{47} \mathrm{Kim}$, Paul and the New Perspective, 218.

${ }^{48} \mathrm{Kim}$, Paul and the New Perspective, 219.

${ }^{49} \mathrm{Kim}$, Paul and the New Perspective, 219.

${ }^{50} \mathrm{Kim}$, Paul and the New Perspective, 220.
} 
For Kim, on the other hand, Paul's Damascus road experience is the origin of Paul's "reconciliation" language. Based on the allusions Kim has observed in the text, he posits the following conclusion: " 2 Cor 5:11-21 is full of allusions to Paul's Damascus experience of conversion/call: what he is talking about in that passage is what happened to him on the Damascus road" (emphasis his). ${ }^{51}$ As will be observed in the following paragraphs, Kim's overstatement of the issue raises cause for concern. With little doubt, Paul's Damascus experience was the dramatic turning point of Paul's life and ministry which formed a great deal of Paul's worldview. Kim's horizon of expectation, however, presses past the point of hermeneutical soundness.

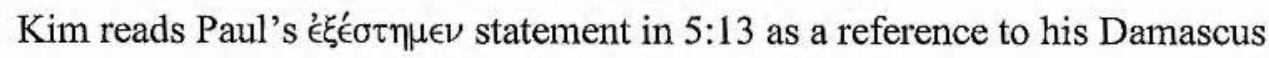
road experience. Quite possibly, Kim asserts, the opponents of Paul in 2 Corinthians had called into question his conversion/call and Paul defends himself with this text. This appears, to the eye of this author, to be an over-reading of the text and context of 2 Corinthians. Paul is most likely referring to the fact that if he has private, ecstatic moments, they are for God. What is best for the benefit of the Corinthians, however, is when Paul is in his right mind..$^{52}$ The epistle reminds us of the Corinthian opponent's pride in their ecstatic experiences and their lamenting of Paul's lack in this arena (cf. 2 Corinthians 12). Paul's conversion experience is not the issue addressed in 5:13, rather, the gratuitous flouting of one's supernatural experiences as a test-case for apostolic validity. Kim's reading of 5:13 presses beyond the confines of the text.

Another example of Kim's over-reading is found in the following statement: "To him, however, 'Jesus' is the Christ who died and was raised for us...This recognition came to him through the revelation of Jesus Christ on the Damascus road $(5: 14) .{ }^{, 53}$ It is affirmed that Paul's world was turned upside down on the Damascus Road; although, one wonders whether any literary connection between 2 Cor 5:14 and Paul's conversion experience is textually present.

Without elongating the examples, one may concur with $\mathrm{Kim}$ that if one were to ask Paul to speak about his reconciliation experience he may in fact point to the Damascus road. Also, the beginnings of Paul's "ministry of reconciliation" may most

\footnotetext{
${ }^{51} \mathrm{Kim}$, Paul and the New Perspective, 236.

${ }^{52}$ Cf. 1 Cor 14:4-5, 18-19. See Furnish, II Corinthians, 324.

${ }^{53} \mathrm{Kim}$, Paul and the New Perspective, 228.
} 
likely be traced to his experience on the road to Damascus. ${ }^{54}$ Kim seems hard pressed, however, to provide literary/textual evidence for Paul's conversion experience as the backdrop for this entire section. Kim, quite possibly, may have fallen prey to the dangers of a psycho-analytical exegesis which seeks to read Paul's mind instead of Paul's words, that is, a phenomenological approach. Does Paul's experience come into play? Certainly, Paul's personal experience is part of his worldview of reconciliation. At the same time, this particular pericope is universal in scope and eschatological in flair with individuals being caught up into God's eschatological work of new creation (5:17). Paul's testimony is no doubt a part of the cosmic work of Christ in new creation, but to argue that Paul's personal Damascus encounter is the governing motif of this section goes beyond the scope of this pericope. ${ }^{55}$ Paul's focus is on something much grander.

Otfried Hofius's article "Erwägungen zur Gestalt und Herkunft des paulinischen Versöhnungsgedankens" puts forward the thesis that 2 Cor 5:14-21 is found in the "grosser Apologie des Apostelamtes 2, 14-7, 4 und bildet den Höhepunkt der Ausfïhrungen... ${ }^{, 56}$ Regarding the Herkunft of Paul's use of "reconciliation," Hofius suggests Deutero-Isaiah as the possible source of Paul's theological thinking. Hofius is careful to draw a distinction between der Begriffe and die Sache, a distinction to which Kim does not give ample weight. ${ }^{57}$ The term (die Begriffe) itself, according to Hofius, most likely is passed forward to Paul from

\footnotetext{
${ }^{54}$ Krister Stendahl's now famous article comes to mind, "Paul Among Jews and Gentiles," in Paul Among Jews and Gentiles and other essays (London: SCM Press,1977), 7-23.

${ }^{55}$ In passing it should be noted that it is of interest that Paul's "testimony" of his Damascus Road experience is never fully elucidated in the Pauline literature. This is not to say Paul did not speak of his calling (e.g. Gal 1:11-17), however, the detailed testimony of the Damascus Road encounter does not fully come out in Paul's literature. Of course this brings up the thorny relationship between the Paul in Acts and the Paul in the Pauline literature. See Martin Hengel, The Pre-Christian Paul (London: SCM Press, 1991).

${ }^{56}$ Hofius, "Erwägungen," 1.

${ }^{57} \mathrm{Kim}$, Paul and the New Perspective, 218-219. Another vantage point would be the distinctions David Yeago, though with a different theological agenda, observes between "concepts" and "judgment." Isaiah is the preferred background for this pericope, and this is yet to be proven, the "judgment" is God's restoring of mankind to himself by the forgiveness of sins in the work of the Suffering Servant.

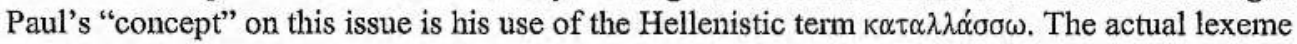
$\kappa \alpha \tau \alpha \lambda \lambda \alpha \dot{\alpha} \sigma \sigma \omega$ should not carry all the weight of significance for this "concept" in 2 Cor 5:14-21. Or more to the point, one should not be surprised to find the Apostle to the Gentiles using a Hellenistic concept to describe a biblical reality based on Paul's narrative reading of Isaiah 40-66. The absence of any lexical connection between Isaiah 40-66 and $\kappa \alpha \tau \alpha \lambda \lambda \alpha \dot{\sigma} \sigma \omega \omega$ does not take away from an Isaianic background, but causes the reader to take into account the biblical concept Paul is seeking to explain in this pericope by way of his lexeme of choice. David Yeago, "The New Testament and the Nicene Dogma: A Contribution to the Rediscovery of Theological Exegesis" in Pro Ecclesia 3 (1994): 152164. In this article Yeago argues that Nicene Dogma, though using different "concepts" than are found
} 
Hellenistic Judaism (cf. 2 Macc 1:5; 5:20; 7:33; 8:29), but he finds in Deutero-Isaiah the content (die Sache) he wishes to communicate. In other words, the term Paul adopts is an appropriate heuristic device for the Scriptural thought Paul is seeking to communicate. ${ }^{58}$

The overlap Hofius observes between Isa 52:13-53:12 2 Cor 5:14-21 is fourfold. 1) The particular and universal stand side by side in both texts. The Suffering Servant dies for us, namely, for the believing community who have confessed his death and resurrection. This particular aspect is coupled with the universal, that is, he died for the many. 2) Both the Servant and Jesus give of themselves freely, while at the same time, they are given by God. 3) The clause of the Apostle found in 5:21, that Christ gave himself for our sins, is found in sharp concentration in Isa 53:6, 9. 4) The concept of "exchange" finds its unique parallel in Isa 53:5. ${ }^{59}$ Hofius's argument does not rest on strict one-to-one parallels in the sense of direct quotation, but centers on the overlap of concepts that are of central import to both the redemptive drama of Isaiah and of 2 Cor 5:14-21. Thus, one observes Hofius's emphasis on the distinction between die Sache and die Begriffe. ${ }^{60}$ Reconciliation, based on the concept of peace, is found in Isa 52:6-10, and the call to be reconciled to God $(5: 20)$ echoes the call to rebellious Israel (Isa 44:22) and the nations (Isa 45:22). ${ }^{61}$ Hofius concludes, "Er hat damit zugleich aus dem Alten Testament die Sprache empfangen, in der er das Heilshandeln Gottes in Jesus Christus auszusagen vermochte."62

G. K. Beale followed Hofius's work with his own exploration into the background of the concept of "reconciliation" and its bearing on the literary problem of 2 Cor 6:14-7:1. Beale correctly states that few scholars have dealt with the OT background to the reconciliation theme of 2 Corinthians. ${ }^{63}$ Beale attributes this lack of scholarly engagement to "a too narrow view of establishing parallels on a semantic basis, often to the exclusion of conceptual considerations." ${ }^{.64}$ On this score, Hofius

\footnotetext{
in Scripture, is faithful to the judgments of Trinitarian doctrine represented in the Biblical texts/narratives.

${ }^{58}$ Hofius, "Erwägungen," 11. Kim (Paul and the New Perspective, 218) observes this point but seems to miss the implications regarding Paul's use of the term as a shorthand for the concept.

${ }^{59}$ Hofius, "Erwägungen," 11.

${ }^{60}$ Hofius, "Erwägungen," 12.

${ }^{61}$ Hofius, "Erwägungen," 12-13.

${ }^{62}$ Hofius, "Erwägungen, " 14.

${ }^{63}$ Beale, "Old Testament Background," 217.

${ }^{64}$ Beale, "Old Testament Background," 218.
} 
and Beale are in accord. Beale seeks to give detailed consideration to the concept of "reconciliation" with a specific OT proposal in mind. His thesis is as follows, "In particular, the overarching thesis of this study is to show that Paul understands both 'new creation' in Christ (2 Cor 5.17-21) as the inaugurated fulfillment of Isaiah's and the prophets' promise of a new creation in which Israel would be restored into a peaceful relationship with God and that this theme extends through the beginning of 2 Corinthians 7." 65

Beale's detailed and careful analysis of the Isaianic background of Paul's thought in 2 Cor 5:17-7:1 is quite helpful in tracing recurring themes present in both Isaiah and this unit of Paul in 2 Corinthians. Also, a large part of Beale's stated purpose is his dealing with the literary integrity of 6:14-7:1. Beale's attempt at defending the unity of 5:14-7:1 is grounded in the unit's Isaianic substructure. The

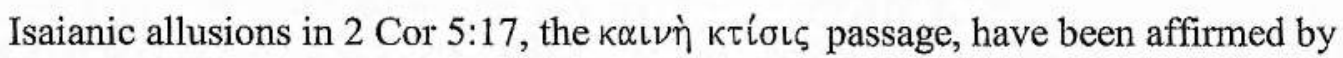
several commentators. ${ }^{66}$ But to Beale's dismay there has been "no specific attempt to link this Old Testament background closely with the following discussion of reconciliation in verses 18-21."67 Beale states, "We can only suppose that there has been no discussion of the recognized links with Isaiah because commentators perhaps view Paul as merely using Isaiah's words to convey his own new thought which is foreign to the Old Testament context.." ${ }^{, 68}$ Beale's methodological proposal seeks to take seriously the OT context with which Paul is working. In other words, Paul's use of the reconciliation theme of Isaiah 40-66 takes seriously the Isaianic context.

Beale's reading of Isaiah 40-66 assumes the exilic background of the book. Sin is the recognized cause that led Israel into exile and "restoration" is "restoration from exile." "N9 "New creation" is shorthand for "restoration from exile" for Beale, and Paul's use of "new creation" in 2 Cor 5:17 implies that the "restoration from exile" has begun in Christ. "The believer's separation and alienation from God because of sin have been overcome through divine grace expressed in Christ, who has restored the believer into a reconciled relationship of peace with God."70

\footnotetext{
${ }^{65}$ Beale, "Old Testament Background," 218-219.

${ }^{66}$ Beale, "Old Testament Background," 220, n. 12.

${ }^{67}$ Beale, "Old Testament Background," 221. Beale is aware of Hofius' article, (218 n. 3), which makes this statement seem a bit misguided.

${ }^{68}$ Beale, "Old Testament Background," 221.

${ }^{69}$ Beale, "Old Testament Background," 223.

${ }^{70}$ Beale, "Old Testament Background," 223.
} 
A major aspect of Beale's thesis surfaces in his discussion of the quotation of Isa 49:8 in 2 Cor 6:2. We will interact with Beale's comments on the actual context of Isa 49:8 subsequently. At this point, it is important to highlight Beale's conclusion regarding the quotation. "In radical fashion Paul applies to himself a prophecy of the Isaianic Servant, probably in order to identify himself with that figure. He is in some way the fulfillment of the righteous "Servant, Israel" (Isa 49:3) who was to proclaim restoration to sinful Israel." ${ }^{, 71}$ In a footnote Beale concedes that it is possible that Paul thought primarily of Christ as the Servant and secondarily of himself in that role. Although, he states that this is unlikely. ${ }^{72}$ Beale gives warrant for his reading of this text on the basis of "corporate representation" and states that Paul could have easily applied the Servant prophecy to himself as an extension of the role of the Servant. ${ }^{73}$

Detailed attention to this particular identification of Paul and the Servant of Isaiah 40-55 will be given in the following chapters, especially regarding Paul's quotation in 2 Cor 6:2. It will be argued that firstly, Paul does not hint at any sort of identification with the Servant in his quotation of Isa 49:8 in 2 Cor 6:2. In fact, Paul's main emphasis is the eschatological now of God's redemptive action. "Now is the acceptable time." Secondly, Paul does observe his own work as the extension of Christ's. On that point, I concur with Beale. It should be quickly added, however, that allusions to the suffering Servant are peppered throughout Paul's writing in 2 Cor 5:14-21 (esp. 21). That Paul would allow this typological significance to slip onto himself in such close proximity (5:21 and 6:2) is not found tenable (again, this will be explored more fully). Thirdly, the Servant of Isaiah 40-55 has a unique and nontransferable identity in Isaiah's own canonical voice, and God's redemptive plan. It

\footnotetext{
${ }^{71}$ Beale, "Old Testament Background," 229. Similarly, Danker has argued that Paul understands his diaconate in 2 Cor 5:14-21 in light of the Servant imagery of Isaiah 40-55 and rests his argument primarily on Paul's appeal to Isa 49:8 in 2 Cor 6:2 (Frederick Danker, "The Theology of 2 Corinthians 5:14-21" in Interpreting 2 Corinthians 5:14-21 [ed. J.P. Lewis; Lewiston: The Edwin Mellen Press, 1989], 87. The argument against Beale applies to Danker as well, though it should be added that Danker's understanding is more theologically promising because of his close reading of the Servant's suffering identity as overlapping with that of Paul's. As will be observed, Danker's sensibilities are headed in the right direction when he states that Paul lists his credentials in 6:3-10 in suffering-servant like fashion (Danker, "The Theology," 88). As will be demonstrated, however, Paul's Isaianic imagery in 2 Cor 5:14-21 places the identity of the Servant of Isaiah 40-55 directly onto Jesus Christ (especially 5:21). The typological clashing in such close proximity, e.g., Jesus as Servant in 5:21 and Paul as Servant in 6:2, renders this reading problematic. Is there another way forward in the literary flow of Isaiah's own voice? It will be argued that there is. As Paul is a servant of the Servant Jesus, so too are there servant followers of the Servant in Isaiah 40-66 whose mission and identity overlaps significantly with that of the Servant without the loss of the uniqueness of their own specific identities.

${ }_{73}^{72}$ Beale, "Old Testament Background," 229, n. 30.

${ }^{73}$ Beale, "Old Testament Background," 231.
} 
will be argued that Paul understood and observed this reality. ${ }^{74}$ Fourthly, it will be argued that the Servant's unique identity and the continuance of his mission by disciple followers is actually found in the figural movement of Isaiah 40-66. This is the movement of Israel-Servant-servants. ${ }^{75}$ In other words, Beale's sensibilities are headed in the right direction, but a better way forward may be present in exploring Isaiah's own canonical voice more fully.

The most detailed work given to the Isaianic background of 2 Corinthians is William J. Webb. ${ }^{76}$ Webb's statement of hypothesis is as follows: "My hypothesis is that the fragment is related to its present context through the use of new covenant and exilic return traditions, particularly in light of Paul's identification with the 'ebed Yahweh." "77 Webb's emphasis is the Isaianic, exilic background of 2 Cor 6.14-7:1 which is indicated by his title, Returning Home. Webb states that this title is a shortened form of his longer dissertation title, Coming out of Babylon and Returning Home. Webb continues, "I have chosen this title in view of its crucial role in the contextual theory, echoing the cry for a new exodus. Its wording derives from a piece of the fragment's tradition ('Come out from among them') which has been heavily redacted in order to reiterate the opening exhortation in $6.14 \mathrm{a}$. In this respect, the book's title epitomizes the call of the fragment from a traditions perspective: 'Come out of Babylon and return home'.,78

Webb's thesis is made clear in his introductory chapter. He is operating within a history of traditions framework coupled with a reading of Isaiah focused on the contingent, historical circumstance of Isaiah 40-66, i.e., Babylonian exile and national עבד יהוה, an identification that, I believe, goes beyond the canonical shape of Isaiah 40-66 and 2 Cor 5:14-6:13. Admittedly, Webb's driving concern is the problem passage of 6:14-7:1 and its literary integrity; however, Webb's approach to the topic, though for the most part on target, is based on an overly historical reading of Isaiah, that is, a reading in which Isaiah's unique voice is dealing with historical realities (with spiritual overtones) while Paul is adopting those historic realities for his own

\footnotetext{
${ }^{74}$ As has been argued by Richard Bauckham (to which I will return shortly).

${ }^{75}$ Christopher R. Seitz, " 'You are my Servant, You are the Israel in whom I will be glorified': The Servant Songs and the Effect of Literary Context in Isaiah," CTJ (2004): 117-134.

${ }^{76}$ William J. Webb, Returning Home: New Covenant and Second Exodus as the Context for 2 Corinthians 6.14-7.1 (JSNTSS 85; Sheffield: Sheffield Academic Press, 1993).

${ }^{77}$ Webb, Returning Home, 14.

${ }^{78}$ Webb, Returning Home, 14.
} 
spiritual/eschatological purposes. This seems to present a false disjunction between the book of Isaiah and its canonical significance for Paul.

An example of Webb's overly historic reading of Isaiah is found in his discussion of 2 Cor $6: 17{ }^{79}$ Paul is quoting Isa 52:11-12 in the midst of his catena of purity quotations. Webb comments, "In language reminiscent of the exodus from Egypt, Isa. 52.11-12 pictures the return of Israel (and especially the Levites) from the defiled city of Babylon." ${ }^{80}$ After teasing out the imagery of Isa 52:11-12, Webb again states, "While Isa. 52.11-12 refers to a literal departure from Babylon, the catena clearly does not." In contrast, Brevard Childs comments on Isa 52:11-12, "Yet it should be observed at the outset that there is no mention of Babylon, and the focus is very different from that of 48:20. The issue is hardly one of geography. Rather, the coherence of these verses is established with 52:1-6...In sum, these final verses draw out the effect of the hymn of praise in 7-10, and demonstrate that the torah of God to Israel is being observed by those who bear his name in accordance with the righteous reign of God in holiness. ${ }^{~} 82$ Webb's reading of Isaiah 52:11 centers on geography. Childs, on the other hand, recognizes holiness as the driving theme of this text, not physical location. Without wanting to overstate the case, Webb does affirm a "symbolic/moral meaning" within the Old Testament. ${ }^{83}$ At the same time, he does seem to make a disjunction between Paul's 'spiritual reading' of Isaiah and the historical sense of Isa 52:11-12, a distinction Childs does not think is present within Isaiah's own canonical voice.

Webb makes a clear case for the identification of Paul with the Servant of Yahweh in Isaiah 40-55. Paul's quotation of Isa 49:8 in 2 Cor 6:2 has led both Beale and Webb to the conclusion that Paul takes on the identity of the Servant as restorer of Zion and more definitively as a light to the nations. ${ }^{84}$ Webb cites a host of scholars who have argued along similar lines. ${ }^{85}$ Paul's identifying himself as the Servant of

\footnotetext{
${ }^{79}$ Webb, Returning Home, 42-43.

${ }^{80}$ Webb, Returning Home , 42.

${ }^{81}$ Webb, Returning Home, 43.

${ }^{82}$ Childs, Isaiah, 406-407.

${ }^{83}$ Webb, Returning Home, 43.

${ }^{84}$ Commenting on 2 Cor 6:2 Beale ("OT Background," 362) states, "In radical fashion Paul applies to himself a prophecy of the Isaianic Servant, probably in order to identify himself with that figure."

${ }^{85}$ Webb, Returning Home, 128. Webb cites Dupont's The Salvation of the Gentiles as support of Paul's identification with the Servant of Isaiah 40-55. Something may have been overlooked in this reading but having reviewed the pages cited several times the closest comment related to the matter was the following: "The assertion that the message of salvation must be carried to all the nations is generally based on the prophecies of the latter half of the Book of Isaiah $(40: 5 ; 42: 7,16 ; 49: 6 ; 57: 19)$ " (Jacqes
} 
Yahweh allows him the authority to issue a new Exodus call, namely, "Come out from among them" (2 Cor 6:14) ${ }^{86}$ Is this move to identify Paul with Isaiah's Servant in Isaiah 40-55 tenable? A fuller analysis of this question will be explored in chapters three and four. For now, a few key questions will be asked to both Beale and Webb's thesis.

\section{4.a Questions Pertaining to Beale and Webb}

Both Beale and Webb have brought to the attention of Pauline scholars the broader Isaianic background of 2 Cor 5:14-7:1, although, their identification of Paul with the Suffering Servant raises questions regarding the warrant of such a move from the canonical shape of Isaiah 40-66 itself. Does the presentation of Isaiah's message of the Servant in its final canonical form support Beale's and Webb's identification of Paul with the Servant? Webb and Beale's projects are not beyond the pale. The criticisms offered here reflect their attenuated understanding of the larger narrative movement of Isaiah 40-66 in light of newer Isaianic research. This larger narratival reading may shed light on a more nuanced and plausible understanding of Paul's figural understanding of both Christ and himself in the drama of Isaiah 40-66.

Another point of divergence, especially with that of Webb, is the apparent collapsing of the sensus literalis onto the sensus historicus ${ }^{87}$. Our reading of the Isaianic drama, though not disconnected from history, will seek to adjudicate between strict historical readings and deeper theological/spiritual readings, which in a canonical reading are not disjointed. Thirdly, Beale and Webb do not do justice to the overall theme of canonical 2 Corinthians, that is, Paul's apostolic self-defense in light of his suffering. Finally, Beale and Webb's Isaianic reading tends to flatten out 2 Cor

\footnotetext{
Dupont, The Salvation of the Gentiles: Studies in the Acts of the Apostles [New York: Paulist Press, 1979], 32. The implication of this statement could be Paul's identification with the Servant; however, Webb's conclusion is made by inference, possibly falling into the realm of non sequiter. Webb's references to Dunn, Hickling, and Bruce seem to be misleading as well. Having said this it should be added, Webb may be working within the semantic realm of 'identification' as 'association' not 'identity.' However, based on the canonical form of both Isaiah and the Pauline literature, the categories of the Servant and servants of the Servant should not be collapsed in spite of their significant, vocational overlap.

${ }^{86}$ Webb, Returning Home, 176. The work of Beale and Webb were produced at the same time. Webb confesses coming to Beale's work late and seeks to show the divergence between himself and Beale (181-182). Still, the overlap between the two is significant. Both Beale and Webb are concerned to deal with the "problem" passage of 6:14-7:1. They both are pressing hard the exilic theme of Isaiah as background to Paul's thought. Moreover, they both seek to identify Paul with the Servant of Yahweh. It should be added that Webb's thesis centers on the identification of Paul with the Servant of Isaiah 4055 , whereas, Beale affirms this notion but does not rest his case upon it.

${ }^{87}$ Our attention will turn to this issue specifically in the last chapter.
} 
6:3-10, which in the view of this interpreter stands as the highpoint of the literary unit

2 Cor 2:14-7:1. In short, Beale and Webb's work is not to be un-substantiated but pushed forward on an issue of which they seem to be unaware, namely, the theme of the servants of the Servant in Isaiah 40-66.

\section{Paul and the Servant of Isaiah 40-55}

Webb is right to assert that many scholars have sought to make connections between the work of the Servant of Isaiah 40-55 and Paul's own vocational identification. ${ }^{88}$ Yet there seems to be a level of confusion surrounding the issue. Is Paul the Servant or is Christ the Servant? Are Webb and Beale using the terminology of "identification" as a shorthand way of saying "association" or are they collapsing the typological significance of the Servant of Isaiah 40-55 onto Paul?

An example of this apparent confusion is noted in David Stanley's article of 1954, "The Theme of the Servant of Yahweh in Primitive Christian Soteriology, and its Transposition by St. Paul." ${ }^{89}$ Stanley is quick to point out that much of early Christianity's soteriology is based on Isaiah 40-55, and Stanley places Paul in the middle of this milieu. However, for Stanley the transposition of the Suffering Servant theme onto Paul's ministry, though definitely a source for soteriological thought, finds its novum in Paul's "become (ing) the Servant." 90 This thought leads to statements such as, "Throughout his missionary career, Paul, whilst ever conscious that Christ Himself is the Servant par excellence, repeatedly reminds his listeners that in his own apostolic labours the work of the Servant is being carried forward." ${ }^{\text {"91 }}$ Or "Paul is able to call himself the Servant because he is an 'ambassador' of the Servant, to continue His ministry among them."92 For Stanley, Paul is aware of his appointment as the Servant of Yahweh, while at the same time, Christ is the Servant. Similar to Webb, Stanley also uses language of "identity" or "identified with." 93 An apparent clash of typological significance is observed in this reading of Stanley's. ${ }^{94}$

\footnotetext{
${ }^{88}$ See n. 80 .

${ }^{89}$ David M. Stanley, "The Theme of the Servant of Yahweh in Primitive Christian Soteriology, and its Transposition by St. Paul," in CBQ 16, (1954): 385-425.

${ }^{90}$ Stanley, "The Theme of the Servant of Yahweh," 413.

91 Stanley, "The Theme of the Servant of Yahweh," 416.

92 Stanley, "The Theme of the Servant of Yahweh," 417.

93 Stanley, "The Theme of the Servant of Yahweh," 421.

${ }^{94}$ See Alexander Kerrigan, "Echoes of Themes from the Servant Songs in Pauline Theology," in Studorium Paulinorium Congressus Internationalis (AnBib 17-18; Rome: Pontificio Instituto Biblico, 1963), 217-228; Paul Dinter, "Paul and the Prophet Isaiah," in BTB 13 (1983): 48-52; Terence
} 
Others have felt the tension in this sort of reading. J. Ross Wagner asserts, "Contrary to the argument of Paul Dinter, the apostle does not conceive of himself as the Servant of Isaiah 52:13-53:12. Rather, he finds himself playing the crucial part of a herald who announces the good news." ${ }^{95}$ Wagner's reading of Paul seems to do more justice to the nuanced narrative of Isaiah 40-55 coupled with the specific role the Servant plays in the drama. Also, Wagner affirms a larger narrative reading of Isaiah that takes in the different hues of a very complex argument on a larger scale.

In Wagner's larger work, Heralds of the Good News, he develops the understanding of Paul's deeper meditation on the larger narrative of Isaiah 40-66 (though mainly 40-55) in Paul's epistle to the Romans. Wagner notes Paul's apparent silence regarding the pertinent Suffering Servant texts in Isaiah that would seem to support the case Paul is making both christologically and ecclesiastically. With that said, Paul does echo the Suffering Servant motifs of Isaiah 53 in Rom 4:25 and 8:32 leading Wagner to side with Richard Hays's conclusions regarding Paul's silence, "[Paul] hints and whispers all around Isaiah 53 but never mentions the prophetic typology that would supremely integrate his interpretation of Christ and Israel. The result is a compelling example of metalepsis: Paul's transumptive silence cries out for the reader to complete the trope." 96 Thus Wagner's reading of Paul and Isaiah "in concert" leads to the following dramatic roles: 1) Heralds of Isaiah 52-53: Paul and the other preachers of the gospel; 2) Message concerning the return from exile-the gospel of Christ; 3) Servant-Christ, though this remains unarticulated the reader draws the conclusion on the basis of Paul's "screaming silence" or metalepsis. ${ }^{97}$ Wagner's thesis is a more nuanced and closer reading of the redemptive drama of Isaiah 40-66 than the previous studies and has led the way in the study of Paul and Isaiah.

Wagner aside, we may observe at this point the apparent confusion in the literature over Paul's particular identity within the redemptive drama of Isaiah 40-66,

Donaldson, Paul and the Gentiles: Remapping the Apostle's Convictional World (Minneapolis: Fortress Press, 1997), 254.

${ }^{95} \mathrm{~J}$. Ross, Wagner, "The Heralds of Isaiah and the Mission of Paul," 222. It should be noted that Wagner does not develop the theme of the servants of the Servant which would include the herald of Isaiah 52:7 and the subsequent offspring of the Servant highlighted in Isaiah 53-66.

${ }_{96}^{\mathrm{J}}$. Ross Wagner, Heralds of the Gospel: Paul and Isaiah <In Concert $>$ in the Letter to the Romans (NTS 101; Leiden: Brill, 2002), 334-335; Richard Hays, Echoes of Scripture in the Letter of Paul (New Haven: Yale Press, 1989), 63; "Who Has Believed Our Message?" 219.

${ }^{97}$ Wagner, Heralds, 335. 
especially in the reading of an Isaianic background in 2 Cor $5: 11-7: 1 .^{98}$ In short, is Paul the Servant or not? Or is there another way of handling the issue of Paul's close identification with the Servant of Yahweh without collapsing the identity of the Servant of Isaiah 40-55 onto Paul? This raises the question of the unique identity of the Servant in Isaiah's redemptive movement and it is to this that attention is now given.

The recent work of Richard Bauckham, God Crucified, will play an important role in our discussion of Paul and the redemptive drama of Isaiah 40-66, and this is an appropriate place to bring him into the discussion. ${ }^{99}$ Bauckham has argued rather persuasively that a way forward in christological studies is to press past the question of God's nature when dealing with the person and work of Jesus Christ to the more fruitful questions pertaining to God's identity. ${ }^{100}$ We will deal more adequately with Bauckham's work in the following chapter; however, at this point we need to recognize that for Bauckham, really for Paul, the Servant of Isaiah 40-55 is caught up in the unique identity of Yahweh. "The Servant in both his humiliation and his exaltation, is therefore not merely a human figure distinguished from God, but, in both his humiliation and his exaltation, belongs to the identity of the unique God."'101 For Bauckham, the typological significance or fulfillment of the Servant of Isaiah 4055 finds its antitype in the person and work of Jesus Christ, the one who is inextricably linked with the very identity of God. This reading of Paul by Bauckham raises a host of questions related to Paul's identity in the redemptive drama of Isaiah 40-66. If Paul is reading the Servant of Isaiah 40-55 as a member of the unique identity of Yahweh, we can be sure Paul would not have assumed that particularly unique role for himself.

For clarity's sake, the definite overlap between Paul and the Servant of Isaiah 40-55 is affirmed; however, it will be argued that a broader reading of Isaiah 40-66's own canonical voice, not strictly Isaiah 40-55, may lead to a more nuanced understanding of Paul and his vocational/eschatological identification. The category argued for in this work, a category largely unnoticed in Pauline studies, is that of the

\footnotetext{
${ }^{98}$ Wagner's thesis deals with Romans and not the Corinthian epistles per se. Also, as mentioned above, Wagner does not interact with the fairly substantial theme of the servants of the Servant.

${ }^{99}$ Richard Bauckham, God Crucified: Monotheism and Christology in the New Testament (Carlisle: Paternoster Press, 1998).

${ }^{100}$ See the excursus following this chapter on "narrative identity."

${ }^{101}$ Bauckham, God Crucified, 51.
} 
servants of the Servant in Isaiah 53-66, a comparable but distinct category whose identity is not collapsed with the Servant of 40-55.

Newer research on Isaiah, e.g., that of Beuken, Childs, and Seitz, has brought to the attention of Isaianic studies that the servants of the Servant is a major theme of Isaiah 56-66. These servant followers of the Servant, the offspring promised in Isa 53:10, carry on the task of the Servant as light to the nations and restorers of Zion. They, like the Servant, suffer in righteousness (Isa 57:1); however, they do not take on the unique role of the Servant, who is the incarnation of Israel and vicarious sinbearer. At least for Paul, this Servant has been caught up into the very identity and uniqueness of Yahweh (cf. Phil 2). Paul's vocational awareness, coupled with his eschatological suffering, is identified best with the servants of the Servant, as a herald of the message of good news, that is, the good news centered on the individual person and work of the Servant. ${ }^{102}$

This Isaianic redemptive drama lays itself out quite nicely in 2 Cor 5:14-21 as the Servant of Yahweh, whose central mission is explicated in Isaiah 40-55, is displayed in his atoning, sin-bearing work as he brings in the eschatological day of new creation (2 Cor 5:17). Moving into 6:1-13, the reader is taken into the dramatic realm of the servants of the Servant (Isaiah 56-66), namely, the heralds of the Servant's work and mission who suffers in righteousness as did the Servant. The redemptive drama of Isaiah 40-66 is made plain before the reader of 2 Corinthians. Paul does not identify himself with the Servant in the sense that he is the Servant of Yahweh, a place in Paul's theology reserved for the very identity of God. He identifies himself as a servant of the Servant whose vocation is inextricably linked to the Servant's work. Though the overlap between the Servant and the servants is great, the distinct categories need to be held in light of the canonical shape of Isaiah and Paul's own theological reading of Isaiah's message.

\footnotetext{
${ }^{102}$ These two themes, Servant and servants of the Servant, will be explored in chapters three and four.
} 


\section{Conclusion}

A larger reading of Isaiah's own canonical voice may fill the lacuna in the identification of Paul with the Suffering Servant made by Beale and Webb, offering a more holistic reading based on the redemptive drama in its entirety as found in Isaiah 40-66. ${ }^{103}$ Our exegetical thesis is as follows: Paul's narrative/vocational identity is located in the heritage of the servant of the Servant of Isaiah 40-66. The Servant of Yahweh, in the theology of Paul, is caught up into the unique identity of God and serves a specific role and function in the person and work of Jesus Christ. Thus, Paul's identity is wrapped up in the servant followers of the Servant who continue to suffer in righteousness as heralds of the message.

\footnotetext{
${ }^{103}$ I should note that this thesis also seeks to broker newer Isaianic research with Pauline studies especially as it relates to the theme of the servants of the Servant.
} 


\section{Excursus: On Narrative Identity-Ricouer and Frei}

Without giving a full-orbed treatment of the philosophical and theological issues related to narrative identity, it seems appropriate to give an overview of narrative identity as it relates to the project at hand. ${ }^{1}$ For it is in the maneuvering between agent and action or between the "who" and the "what" that gives purchase to the concept of identity or identification. The question of narrative identity, especially as it relates to literature, and in this case, the biblical story, presses beyond the what questionquestions pertaining to nature - to the who of narrative identity as presented in the temporal flow of a narrative sequence. Thus, the entrance into discussion of a character's identity is made more readily available as one begins to look at the sequence of actions the character performs literarily as a display of the person's character, in other words, a character's narrative identity.

\section{Narrative Identity in Paul Ricouer}

Within philosophical circles, Ricoeur's work Oneself as Another stands at center stage in the recent discussion of narrative identity. Ricoeur places the discussion of identity, or self-hood, in categories of ipse and idem. The ipse is understood most properly as "self-hood" whereas idem reflects the more static concept of "sameness." Ricoeur states, "Selfhood, I have repeatedly affirmed, is not sameness." Within the realm of identity as idem, the highest order of signification is that of "permanence in time."3 Ipse-identity, on the other hand, reflects no "unchanging core of the personality."4 Ricouer's category of choice is that of self-hood or ipse.

With this stated, however, Vanhoozer, listening to Ricoeur, is right to assert that "to be a self there must be some permanence through time."

\footnotetext{
${ }^{1}$ For further reflection see Paul Ricouer, Oneself as Another (transl. by Kathleen Blamey; Chicago: Chicago Press, 1992); Hans Frei, The Identity of Jesus Christ (Minneapolis: Fortress Press, 1975); Robert Jenson, The Triune Identity: God According to the Gospel (Oregon: Wipf and Stock, 2002); Richard Bauckham, God Crucified, chapter 1; David Ford, Self and Salvation: Being Transformed (Cambridge: CUP, 1999); Ronald F. Thiemann, Revelation and Theology: The Gospel as Narrated Promise (Notre Dame, University of Notre Dame Press, 1985), chapters 5 and 6; Kevin Vanhoozer, "Does the Trinity Belong in a Theology of Religions? On Angling in the Rubicon and the "Identity" of God," in First Theology: God, Scripture, and Hermeneutics (Downers Grove: IVP, 2002), 45-70.

${ }^{2}$ Ricoeur, Oneself as Another, 116.

${ }^{3}$ Ricoeur, Oneself as Another, 2.

${ }^{4}$ Ricoeur, Oneself as Another, 2. Or as Vanhoozer states, "Ipse-identity-selfhood—is not merely sameness. To be a self is more than to enjoy an uninterrupted persistence in time." Vanhoozer, "Does the Trinity," 51.

${ }^{5}$ Vanhoozer, "Does the Trinity," 51.
} 
discussion of the various questions posed to the notion of action as related to agentsquestions such as who?, what?, why?, where?, when?, how? ${ }^{6}$ Ricoeur, in study three, laments the move made by analytic philosophers of placing the question "what" strictly in the realm of the question "why."7 This has led, in the opinion of Ricoeur, to the "occultation of the question "who?"8 In other words, questions pertaining to the intentionality and motivation of the action have eclipsed questions related to the "who" of the agent of the action. ${ }^{9}$ Ricoeur, in the fourth study, moves the question backward from the "what-why" pair to the question of identity, the "who?"10

Answers to the "who?" question are located in the description of an agentcentering on integrating queries such as "what?" "why?" "how?" The actions performed within temporal movement are in a sense owned by the agent of the action. ${ }^{11}$ Thus, "it is in terms of the entire network crisscrossing the semantics of action that we understand the expression 'agent'."12 Again, one notes Ricoeur's allergy to the description of human action under the rubric of "impersonal event."13 The questions "what?" and "why?" (idem-identity) reflect an attenuated understanding of the agent of the actions or the "who?" (ipse-identity) and so leads to static and impersonal conceptions of identity.

Ricoeur moves beyond this attenuation, the separation of the "what?" "why?" from the "who?", by placing the discussion in the realm of narrative. For Ricoeur, personal identity can only be articulated in "the temporal dimension of human existence." ${ }^{\prime 14}$ It is precisely at this point that the dialectic of the idem and the ipse comes to the fore. Also, questions pertaining to the "permanence in time" of personal identity are placed in the context of this dialectic. Ricoeur states his hypothesis in the following way: "the polarity I am going to examine suggests an intervention of narrative identity in the conceptual constitution of personal identity in the manner of a

\footnotetext{
${ }^{6}$ Ricoeur, Oneself as Another, 58.

${ }^{7}$ Ricoeur, Oneself as Another, 60.

${ }^{8}$ Ricoeur, Oneself as Another, 60.

9 "The criterion of intentional-hence of "what?" of action-is in fact the form assumed by certain responses given to the question "why?" In this sense, the "why?" controls the "what?" and, in so doing, leads away from an interrogation concerning the "who?" Ricoeur, Oneself as Another, 68 . See also Ricoeur's analysis of Donald Davidson's work, Essays on Actions and Events (Oxford: Clarendon Press, 1980), as a relegating of identity to idem on the basis of the elision of the question "who" in the "what-why" framework of analysis. Ricoeur, Oneself as Another, 85

${ }^{10}$ Ricoeur, Oneself as Another, 88.

${ }^{11}$ Ricoeur, Oneself as Another, 95; see also p. 100.

${ }^{12}$ Ricoeur, Oneself as Another, 95

${ }^{13}$ See David Ford, Self and Salvation, 87.

${ }^{14}$ Ricoeur, Oneself as Another, 114.
} 
specific mediator between the pole of character, where idem and ipse tend to coincide, and the pole of self-maintenance, where selfhood frees itself from sameness."

Character, according to Ricoeur, is the distinguishing marks of a human agent allowing for the reidentification of that person. It is the discussion of character as such that illumines the dialectic of ipse and idem. ${ }^{16}$ Ricoeur refers to character as a sort of sedimentation of the self, a sedimentation that illumines the overlap between the "selfhood" and "sameness." Ricoeur makes a precise analysis, "This overlapping, however, does not abolish the difference separating the two problematics: precisely as second nature, my character is me, myself, ipse; but this ipse announces itself as idem." ${ }^{17}$ Recognizing this stability of character as portrayed differently in the narrative episodes of life, allows for one to make the observation that "so and so" is "acting completely out of character." "18 Thus, "Character is truly the "what" of the "who." 19 Character as sedimentation has the ability to overcome its static nature by redeployment in narrative. For example, Jim as an honest person (sedimented character) comes to an event in life, say his tax return, and reports numbers honestly. Thus, a faithful demonstration in a narrative event of Jim's character.

It is within a narrative that character is revealed. Similar to Aristotle's maxim that "character is plot," Ricoeur affirms the notion that the actions performed in a narrative are carried out by a character. This leads Ricoeur, in a sense turning Aristotle's maxim on its head, to state, "characters, we will say, are themselves plots." ${ }^{20}$ Ricouer rightly stresses that outside of narrative questions such as "what?" "why?" and "who?' can be treated in isolation. It is, however, from a syntagmatic perspective that these questions are found in a chain, the story chain. ${ }^{21}$ "Telling a story is saying who did what and how, by spreading out in time the connection between these various viewpoints...It is in the narrative, however, that attribution is reestablished."22

\footnotetext{
${ }^{15}$ Ricoeur, Oneself as Another, 118-119.

${ }^{16}$ Ricoeur, Oneself as Another, 119.

${ }_{17}^{17}$ Ricoeur, Oneself as Another, 121.

${ }^{18}$ Ricoeur, Oneself as Another, 122.

${ }^{19}$ Ricoeur, Oneself as Another, 122. Ricoeur observes another mode of "self-constancy" and that is keeping one's word through time. "Keeping one's word expresses a self-constancy which cannot be inscribed, as character was, within the dimension of something in general but solely within the dimension of "who?" Ricoeur, Oneself as Another, 123,

${ }^{20}$ Ricoeur, Oneself as Another, 143; see also Donald E. Polkinghorne, Narrative Knowing and the Human Sciences (New York: State University of New York Press, 1988), 18-22.

${ }^{21}$ Ricoeur, Oneself as Another, 146.

${ }^{22}$ Ricoeur, Oneself as Another, 146.
} 
There is a dialectical tension between the agent's action and character in a narrative. This dialectic consists in the fact that, on the one hand, a character draws her distinctness from "the unity of life considered a temporal totality which is itself singular and distinguished from all others. ${ }^{, 23}$ On the other hand, the vicissitudes of life seem to threaten this temporal unity. It is in this dialectic that the unity of an emploted character can be understood. ${ }^{24}$ "The person, understood as a character in a story, is not an entity distinct from his or her "experience." Quite the opposite: the person shares the condition of dynamic identity peculiar to the story recounted. The narrative constructs the identity of the character, what can be called his or her narrative identity, in constructing that of the story told. It is identity of this sort that makes the identity of the character." ${ }^{25}$ Recalling Ricoeur's turning of Aristotle's maxim on its head, the character is not controlled by the plot but is put to the test by the plot revealing the character's true identity. ${ }^{26}$ Again, narrative identity overcomes the polarization of sameness and self-constancy. For in narrative, the permanence of character is revealed in self-constancy within the ebb and flow of the narrative's, or life's, tortuous route. ${ }^{27}$ That is, a tortuous route taking place across and through time.

It is in the dialectic of $i d e m$ and ipse that character is revealed. Ricoeur passes beyond the entrenchment of the self as sameness by placing the self in a temporal narrative, as in a literary novel, where one's character is displayed in different temporal activities with all its discordance and unpredictability. It is within the temporal narrative that character displays itself in different fashions and in different circumstances. Thus, the question of the "who?" is related to the question of the "what?" If one is able to answer the question "who?", then one must be able to

\footnotetext{
${ }^{23}$ Ricoeur, Oneself as Another, 147.

${ }^{24}$ Ricoeur, Oneself as Another, 147.

${ }^{25}$ Ricoeur, Oneself as Another, 148.

${ }^{26}$ Ricoeur, Oneself as Another, 148.

${ }^{27}$ Polkinghorne affirms the overcoming of the ipse and idem polarization by means of self-identity in narrative. As with Ricouer, Polkinghorne stresses that narrative identity presses beyond the "self as a body" or the "self as a unique mental substance" (Descartes) or the "self as a construction" (William James) positions. "Self identity becomes linked to a person's life story, which connects up the actions into an integrating plot." Polkinghorne, Narrative Knowing, 151. "The position taken in this study is that we achieve our personal identities and self concept through the use of the narratives configurations, and make our existence into a whole by understanding it as an expression of a single unfolding and developing story. Polkinghorne, Narrative Knowing, 150. The self is more than a series of predicates applied to a subject. The self is organized meaningfully in a narrative sequence over time revealing a character's character in plot. Polkinghorne, Narrative Knowing, 146-155. In fact, Polkinghorne's analysis of narrative identity is quite helpful in light of Ricoeur's rather dense reading. See also, Anthony Thiselton, New Horizons in Hermeneutics: The Theory and Practice of Transforming Bible Reading (Grand Rapids: Zondervan, 1992), 567-69. It should also be stated that Ricoeur uses literary categories as a window into discussion of narrative identity in "real life."
} 
analyze and observe the "what?" of a person's character as displayed over a temporal sequence of events - again, the overcoming of the opposition of character as sedimentation and identity as self-constancy. Ricoeur emphasizes the reciprocating relationship that each of these questions have to one another-the "who?" "what?" and "why?" The guiding principle through the morass of difficulties related to each one of these questions is not to treat them in isolation but to bring them together in a dynamic understanding that is most illuminated by the narrative's revealing of one's identity. ${ }^{28}$

\section{Narrative Identity and Hans Frei}

Hans Frei's particular interest in narrative as a means of identification centers on a different set of concerns than those held by Ricoeur. Charles Campbell places Frei's seminal work, The Identity of Jesus Christ, in the context of Frei's seeking to overcome the impasse between historical-criticism and theology. ${ }^{29}$ A literary approach, as exemplified in Identity, is able to offer a theological reading of Scripture, a reading historical-criticism has kept at bay. ${ }^{30}$

In The Identity of Jesus Christ, Frei uses contemporary philosophy in an ad hoc fashion as he seeks to understand Jesus Christ's identity and presence, not allowing any one particular philosophical system to rest in a hegemonic relationship to theology. ${ }^{31}$ Recognizing the subservient role philosophy takes to theology, Frei takes his cue from Barth. ${ }^{32}$ One must use certain philosophical categories when coming to the text or in describing Christian theology, however, these categories are tools of description which never take the place of the logic of belief. ${ }^{33}$ This logic of belief is located in the gospel story itself, in gospel as narrated event. Therefore, any

\footnotetext{
${ }^{28}$ Ricoeur's study is related specifically to the question of ethics, which is beyond the scope of this project. See David Ford's Self and Salvation.

${ }^{29}$ Charles L. Campbell, Preaching Jesus: New Directions for Homiletics in Hans Frei's Postliberal Theology (Grand Rapids: Eerdmans, 1997), 15.

${ }^{30}$ Frei was also able to move beyond the older Biblical Theology movement with his literary reading. Campbell states, "For example, Frei's literary approach offered a specific interpretation of the unity of Scripture. Frei focused on the final form of the text, rather than on variety 'pieces' that went into the composition of the Bible. In addition, like Barth, he not only stressed the Christological unity of Scripture, but defended typology (or figuration) as the vehicle through which this unity is manifested in the biblical narrative." Campbell, Preaching Jesus, 15. For further exploration see Hans Frei's Eclipse of Biblical Narrative.

${ }^{31}$ Campbell, Preaching Jesus, 15-16.

${ }^{32}$ See Hans Frei, Types of Christian Theology (New Haven: Yale Press, 1992), chapter 6, esp. 81.

${ }^{33}$ Campbell, Preaching Jesus, 48. Frei maintains that Scripture, in spite of the various philosophical approaches or pre-commitments of its readers, continues to "shape and constrain the reader." Frei, Types, 85-87.
} 
philosophical schema used is subservient to the gospel story itself. ${ }^{34}$ As Frei states, "The meaning of the doctrine is the story; not: the meaning of the story is the doctrine." 35

Our particular purpose in exploring Frei's framework of Christology is to understand his own contribution to the discussion of identity as a narrated event, especially the identity of Jesus Christ. For Frei, discussion of Jesus' identity is in some sense prolegomena to a discussion of Jesus' presence in Spirit. ${ }^{36}$ Identity is defined as the core of person's being. "Like spokes to the center of a wheel" one's identity is center toward which everything else is ordered. ${ }^{37}$ In short, "Identity is the specific uniqueness of a person, what really counts about him, quite apart from both comparison and contrast to others." 38

Though Frei does not use the categories of ipse and idem in his discussion of identity, he does, however, refer to the dialectic tension between these two conceptual categories in the defining of one's identity. One's identity is the composition of all that makes that person unique ("sameness" if you will). The tension comes, for Frei, in what he terms an "identity crisis." A crisis of identity comes when a person acts in disjunction with his or her past. "A person may arbitrarily and artificially reconstruct his past or suppress it altogether. Identity, without this type of crisis, means that a person is one and the same over a period of time, that there is a connection or

\footnotetext{
${ }^{34} \mathrm{John}$ Webster, leaning on Barth as well, makes similar statements regarding theology and modern hermeneutical theory. For Webster, modern hermeneutical theory must be viewed as a tool to do the job. Anything other than this functional use of hermeneutical theory presses beyond the theological account of the task of Christian theology / exegesis. John Webster, "Hermeneutics in Modern Theology," in Word and Church: Essays in Christian Dogmatics (Edinburgh: T\&T Clark, 2001), 7172.

${ }^{35}$ Frei, Types, 90. It is beyond the purview of this work to enter into the theological debate surrounding the statement Frei makes. Statements such as the one quoted above have brought Frei and the likes of George Lindbeck under critiques such as the following by John Webster: "Whilst no serious Christian theologian will ignore Frei's warnings against the transformation of literary description 'into an explanatory scheme using abstract concepts and categories' (p. 125), some such scheme is, I believe, indispensable. However 'second-order', however analytic of the primary narrative presentation of Jesus, Christological categories such as substance, nature, an- and enhypostasia are, handled properly, a way of identifying what is happening in the narratives, without supplanting them or making them into illustrations of a conceptual scheme. They have, moreover, proved themselves capable of facilitating protest against the very thing which Frei himself disputes: the reduction of Christology to Christian spiritual or moral experience." John Webster, "Response to George Hunsinger," in Modern Theology 8 (1992), 130. See also George Hunsinger, "Hans Frei as Theologian: The Quest for a Generous Orthodoxy" in Modern Theology 8 (1992), 103-128. In conversation with Lindbeck, though appropriate in the discussion with Frei, Brevard Childs expresses the danger of an over emphasis on "intratextuality" at the expense of the texts character as witness to something beyond itself. Brevard Childs, The New Testament as Canon: An Introduction (London: SCM Press, 1984), 545.

${ }^{36}$ Frei, Identity, 37.

${ }^{37}$ Frei, Identity, 37.

${ }^{38}$ Frei, Identity, 37.
} 
unbroken relationship between the past and present experience of the same self." 39 Frei, in a manner distinct from but similar to Ricoeur, presses beyond the identity as sameness construct with the help of placing identity in the context of narrative. First, Frei offers an "intention-action" description. "For a person is not merely illustrated, he is constituted by his particular intentional act at any given point in his life." 40 The "intention-action" description gives purchase to the question "what?" and is demonstrated in the narrative account of one's life. Secondly, Frei moves to the "who?" question. The answer to this particular question is located in a person's "selfmanifestation." In Ricoeur's terminology, this is the character of the agent in the narrative, or, that aspect of the person demonstrated in the stability of habit-formation or the sedimentation of character. Again, the overlap of Ricoeur's concerns are evident in Frei. The "intention-action" aspect of identity highlights the narrative element of a person's identity demonstrated temporally whereas the character of a person is that stable part of the person's identity (the overcoming of the ipse/idem polarity). ${ }^{42}$

Frei takes this model of "intention-action" and "self-manifestation" and addresses his particular concern of the bifurcation of Jesus actions from his intentions in the recent historical Jesus quests. For the "Questers," a focus on Jesus' selfunderstanding became the key to understanding the historical Jesus. ${ }^{43}$ For Frei, the question "What was he like" can only be answered by the descriptor, "Look at what he did on this or that occasion. Here he was characteristically himself." "44 Like Ricouer, Frei stresses that plot is subservient to character. "A person is what he does centrally and most significantly." 45 Thus, one's identity, particularly that of Jesus, is found in the enactment of intentions. The one illumines the other and both are necessary for the identification of a person in a narrative sequence. Though Frei separates "intention-action" from "self-manifestation" a bit too strongly, the overlap of the two, as in Ricoeur, is noted. It is in the narrative event that the singularity of the

\footnotetext{
${ }^{39}$ Frei, Identity, 38.

${ }^{40}$ Frei, Identity, 44.

${ }^{41}$ Frei, Identity, 44.

${ }^{42}$ See also David Kelsey, "Biblical Narrative and Theological Anthropology," in Scriptural Authority and Narrative Interpretation, (Philadelphia: Fortress Press, 1987), 130-131.

${ }^{43}$ Frei, Identity, $89 \mathrm{ff}$.

${ }^{44}$ Frei, Identity, 91.

${ }^{45}$ Frei, Identity, 92. See also John David Dawson, Christian Figural Reading and the Fashioning of Identity (Berkeley: University of California Press, 2002), 161.
} 
person's character is revealed in different manifestations yet with a "self-constancy" that can be pointed to and said, "that is so and so with their own unique identity.",46

\section{Conclusion}

What is gleaned from the previous discussion of narrative identity in both Ricoeur and Frei is the movement beyond the impasse of the questions "what?" and "who?" In fact, the "who?" is defined by the "what?" in the narrative dimension of temporal sequence, and for that matter, the "what?" is also defined by the "who?". A person's identity is not static or sameness but is the manifestation of character through the different episodes of the narrative's various twists and turns. It is in this sense that one can identify another by saying, "That is..." or by saying the antithesis, "So and so is acting out of character." It is also in this sense that one is truly another, truly unique.

Several theologians have recently picked up on this theme and applied it to theology, in a manner similar to Frei. One thinks of the work of Ronald Thiemann and Robert Jenson in particular. ${ }^{47}$ As pertains to the project at hand, Richard Bauckham's recent work God Crucified is the most pertinent. For in this small treatise, Bauckham asks the "who?" question as a means of identifying God and Jesus. Bauckham's conclusions is that Jesus' own narrative and actual identity is bound in the unique identity of God. In fact, God's own identity is revealed in Jesus. ${ }^{48}$ Bauckham leans quite heavily on Paul's reading of Isaiah 40-55 as expressed in Phil 2:5-11. For Paul, and Isaiah for that matter, the Servant of Isaiah 40-55 is a part of the unique identity of God. ${ }^{49}$ God's actions and intentions with the world are manifested in the actions of the Servant as subsumed in the fulfilled actions of Jesus. Thus, when Paul attributes Isa 45:22-23 to Jesus in Phil 2:10-11, there is no slight of hand taking place with Paul's exegesis. In actuality, Paul is reading Isaiah 45 in light of the larger Servant

\footnotetext{
${ }^{46}$ I should note that for Frei, Jesus' narrative identification in the gospels and in Paul is most defined, by character that is, as "obedient." Interestingly enough for our purposes, Frei states, "The context or meaning of that obedience is the pattern of merciful, saving activity drawn largely from the picture of the obedient, righteous servant in Deutero-Isaiah." Frei, Identity, 111. It will be observed later that the identity of the Servant as obedient sufferer who gives himself on behalf of and in the place of others is a narrative identity that overlaps with the particular identity given to Jesus in both the gospels and by Paul in 2 Cor 5:14-21.

${ }^{47}$ Thiemann, Revelation and Theology; Robert Jenson, Systematic Theology, Volume 1 (Oxford:

Oxford Press, 1997). For example, Jenson poses the question "Who is God?" and states that the proper biblical answer to this question is, and I paraphrase, "God is one who rescued Israel from Egypt and raised Jesus from the dead." Jenson, Systematic Theology, 44.

${ }^{48}$ Bauckham, God Crucified, viii.

${ }^{49}$ Bauckham, God Crucified, 51.
} 
context and recognizing that Jesus as fulfillment of the Servant is, as the Servant was in Isaiah 40-55 (see esp. 52:13), a part of the very identity of Yahweh. ${ }^{50}$

The cash value of narrative identity, used in an ad hoc fashion, is observed most poignantly in the work of Bauckham as one begins to view the unique identity of both the Servant and Jesus is that of another, another caught up in the unique identity of God. For it is the movement from the "what" to the "who" that one's identity is manifested in a temporal narrative, and God has identified himself in the narrative of Scripture with the Servant in Isaiah as fulfilled in the person of Jesus Christ in the New Testament. Or as Paul would say, "God was in Christ reconciling the world to himself' (2 Cor 5:19). ${ }^{51}$

\footnotetext{
${ }^{50}$ For further development of this type of thought see Robert Jenson, "The Bible and the Trinity," in Pro Ecclesia vol. XI, no. 3 (2002), 334-335.

${ }^{51}$ This will be discussed in greater detail in the exegetical section of the project. It is mentioned here as a sort of foreshadowing of the ways in which narrative identity will be employed in the discussion of the Servant/servants in Isaiah and in Paul.
} 


\section{CHAPTER THREE}

\section{THE SERVANT OF YAHWEH AND 2 CORINTHIANS 5:14-21: PAUL'S READING OF THE REDEMPTIVE DRAMA OF ISAIAH 40-66}

\section{2 Corinthians 5:14-21 and its Literary Context}

The importance of this particular passage in Pauline studies cannot be understated. Barrett has referred to 2 Cor 5:11-21 as "one of the most pregnant, difficult, and important [passages] in the whole of the Pauline literature." ${ }^{\text {"l }}$ The most recent attempt at understanding the literary context of 2 Cor 5:14-21 is that of Hendrikus Boers. Based on grammatical and syntactical/semantic "problems," Boers draws the conclusion that 2 Cor 5:14-21 is a "fragment of Pauline Christology" whose "relationship...to its current context in 5:11-13 and 6:3-10 is unsolvable."2 Boers recognizes 5:11-13 and 6:3-10 as part of Paul's self-defense but notes that 5:14-6:2 makes no "explicit reference" to Paul's apostolic defense. ${ }^{3}$ Though there may be an implicit reference to Paul's self-defense in this pericope, to press the issue would force an unnatural reading on the text. ${ }^{4}$ Boers helpfully discusses the "widest possible spectrum" of views on this text using Windisch and Bultmann as respective representatives. $^{5}$

Windisch traces the problem of this passage to its redactional formation. In short, 5:14-21 was misplaced. 5:11-13 goes with 6:3-10 and 6:1-2 should be placed with 6:14-7:1, thus, leaving 5:14-21 misplaced and un-related to its present context. ${ }^{6}$ Bultmann, on the other hand, "considers the entire passage a unity concerning the apostolic office," that is, 5:11-6:10. ${ }^{7}$ For Bultmann, 5:18-6:2, though not directly speaking of Paul, is meant to establish Paul's own apostolic authority within the framework of "the events of salvation."

\footnotetext{
${ }^{1}$ C. K. Barrett, A Commentary on the Second Epistle to the Corinthians (New York: Harper \& Row, 1973), 163; Martin, 2 Corinthians, 118.

${ }^{2}$ Hendrikus Boers, "2 Corinthians 5:14-6:2: A Fragment of Pauline Christology," in CBQ 64.3 (2002), 545.

${ }^{3}$ Boers, "2 Corinthians 5:14-6:2," 525.

${ }^{4}$ Boers, "2 Corinthians 5:14-6:2," 525.

${ }^{5}$ Boers, "2 Corinthians 5:14-6:2," 525-526.

${ }^{6}$ Boers, "2 Corinthians 5:14-6:2," 527-527.

${ }^{7}$ Boers, "2 Corinthians 5:14-6:2," 528.

${ }^{8}$ Boers, "2 Corinthians 5:14-6:2," 528.
} 
Boers finds both positions untenable. He argues on syntactical and grammatical grounds that 5:14-6:2 has its own literary integrity and is a "rare fragment of Pauline christology." For Boers, the $\gamma \alpha$ ó of 5:14 begins a new theme for Paul, the theme of the relationship between him and his readers. Thus, the $\eta \mu \alpha \hat{\alpha} \varsigma$ of v. 14 is no longer an apostolic "we" but a reference to both Paul and his readers. A fissure had come to the relationship, and Paul points to the work of God in Christ as the foundation of his ministry of reconciliation $(18-21){ }^{10}$

Though Boers offers detailed and helpful exegetical comments on 5:14-6:2, his arguments for this pericope's contextual disjunction are unpersuasive. The appeal for a change in theme in 5:14 on the basis of Paul's use of the plural, $\dot{\eta} \mu$ í $\nu$, does not take into account the use of the plural in 5:11-13. There is no apparent reason to remove 5:14-6:2 from the flow of Paul's argumentation or self-defense, though it should be quickly added that Paul is not only offering a self-apologetic in 5:14-21an unfortunate reductionism. Paul is definitely contributing to a unique christological perspective in 5:14-6:2, coupled with soteriological and eschatological aspects.

However, all of these issues are contextually placed in the midst of Paul's seeking to place himself in God's programmatic redemptive work in Christ. Paul is a master of spinning several plates in the midst of a larger argument, a redaction critic's nightmare, and this particular pericope is a case in point. Paul's arguments are not necessarily tight and neat but multi-perspectival and variegated. This should not lead us necessarily to think of Paul as inconsistent or incoherent. Paul is offering a defense of his own ministry which includes deep and unique thought on the ministry of Christ. Therefore, it is argued that 5:14-21 is placed within the flow of Paul's larger selfapologetic and is key to the internal logic of Paul's self-defense. ${ }^{11}$

The literary unit 5:11-6:13 is found within the climax of Paul's self-

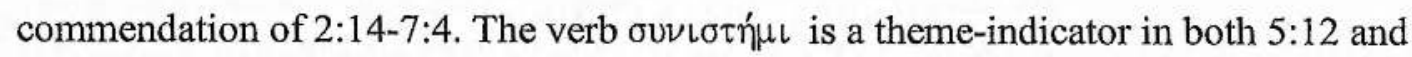
6:4, leading to Paul's emotive appeal in 6:11-13. Paul is commending his own ministry on the basis of what Paul deems a plausible commendation, namely, his own

\footnotetext{
${ }^{9}$ Boers, "2 Corinthians 5:14-6:2," 546 .

${ }^{10}$ Boers, "2 Corinthians 5:14-6:2," 521.

${ }^{11}$ On this passage being a pre-Pauline reception by Paul—a position held by Käsemann, Martin, and others-Porter rightly states, "In light of the fact that the original source can only be imprecisely reconstructed, the interpreter must deal with the canonical text, working from the not unreasonable presumption that the statements unless otherwise supported by firm argument are consonant with Pauline thought. The conclusion can only be that in any meaningful sense for interpretive purposes the
} 
work is a part of God's work in Christ. The fact that Paul's argumentation is not a simple " 1 " "2" " 3 " should not alarm the modern interpreter but alert the interpreter to the possibilities of the text in light of Paul's overarching theme. Therefore on a surface level, we will argue that Paul is moving toward the climax of his selfcommendation in 2:14-7:4, and 5:14-21, as has been said, fits within the rhetorical flow of 5:11-6:13.

Beyond this, however, we will also argue that there is an underlying substructure holding this passage together, i.e., the redemptive drama of Isaiah 4066. ${ }^{12}$ Paul's deep reflection and meditation on the Isaianic redemptive drama has both informed and influenced Paul's understanding of the person and work of Christ as well as his own vocational placement in that redemptive drama. In other words, Isaiah's canonical voice has exerted a considerable amount of pressure on Paul's figural/theological reflection, thus, influencing his own conclusions regarding God's actions for the world in Christ and Paul's placement in the midst of God's present, eschatological activity. To gain further purchase on Isaiah's presence and pressure in Paul's thought our attention turns to the quotation of Isaiah in 2 Cor 6:2.

\section{2 Corinthians 6:2 as Hermeneutical Key}

As late as 1989, Jan Lambrecht lamented the relatively little attention given to the Isaiah quotation in 2 Cor $6: 2$ in both commentaries and other studies. ${ }^{13}$ Lambrecht lists a host of scholars who have passed by the quotation with little discussion, including Furnish's "voluminous commentary." 14 To this list I would add the commentaries on 2 Corinthians by Martin and Thrall. ${ }^{15}$ At the same time, recent investigations into the Isaianic background of this corpus have emphasized 2 Cor 6:2 as an example of Paul's identification with the Servant of Yahweh. Paul is entering into the context of Isaiah 49:8, the second of the so called "servant songs," and is

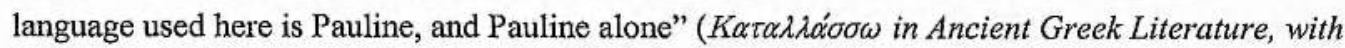
Reference to the Pauline Writings [Cordoba: Ediciones El Almendro, 1994], 130).

${ }^{12}$ Boers gives no attention to possible background thought for Paul in this section, including clear Isaianic allusions and citation.

${ }^{13}$ Jam Lambrecht, "The Favorable Time: A Study of 2 Cor 6, 2a in Its Context" in Vom Urchristentum zu Jesus (ed. by H. Frankemölle and K. Kertelge; Freiburg: Herder, 1989), 377.

${ }^{14}$ Lambrecht, "The Favorable Time," 377 n. 3.

${ }^{15}$ Ralph P. Marltin, Word Biblical Commentary: 2 Corinthians (Waco: Word Publishers, 1989), 167170. Martin discusses Paul's use of the Isaiah quotation describing it as a possible "pesher." However, an examination into the context or thought world of the Isaianic quotation is absent. Thrall states that the context of Paul's quotation is that of the Servant of the Lord. She denies an identification of Paul
} 
applying to himself the role and vocation of the Servant of Yahweh. ${ }^{16}$ How exactly is 2 Cor $6: 2$ working within the context of Paul's argument?

The $\gamma \alpha \alpha \rho$ of $6: 2$ operates in a causal function. Thus, Paul's train of thought in 6:2 flows from his statement in 6:1. It is difficult to track Paul's precise thought in $6: 1$

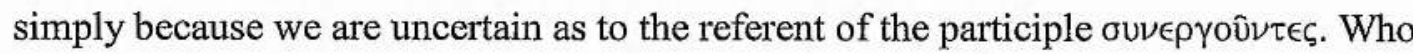
exactly is Paul "working together with"? Three options having been suggested. Paul could be "working together with" 1) other teachers, 2) the Corinthians, or 3) God. ${ }^{17}$ The most tenable position, and the one held by the majority of scholars, is the third option-Paul is "working together" with God. The apostle refers to himself as

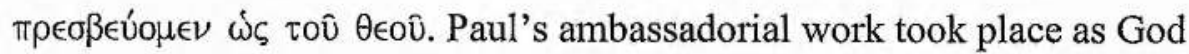

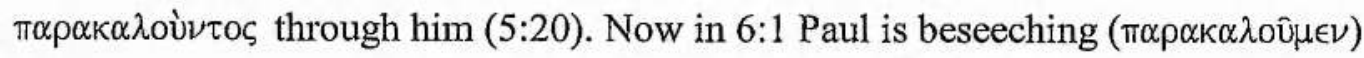
the Corinthians as an ambassador who is a "fellow-worker" with God. In other words, Paul's plea to the Corinthian church is God's plea. ${ }^{18}$

The instigating factor of Paul's beseeching or pleading is directly related to the attitude with which the Corinthians believers received the grace of God. In 5:14-21, Paul displays in glorious fashion the work of God in Christ on behalf of humanity, of which the Corinthians were recipients. Why would Paul be so adamant about the Corinthians not receiving the grace of God in vain? Because the current era in which they live is the eschatological now of God's work in Jesus Christ (6:2). Paul's beseeching of the Corinthian church is, according to $6: 1$, the actual beseeching of God through Paul. Thus, Paul moves from verse 1 to verse 2 and uses a Scripture citation to further his claim.

Attention has been given to the referent of the oou and ool of 6:2 and Isa 49:8 (LXX). ${ }^{19}$ Our reading of the dramatic narrative of Isaiah will follow subsequently. Ai

with the Servant as the motivating factor for Paul's quotation. Unfortunately, Thrall's (II Corinthians, 453) remarks are scant.

${ }^{16}$ We have discussed these views in chapter 2, e.g. Beale and Webb.

${ }^{17}$ Martin, 2 Corinthians, 164-165.

${ }^{18}$ See Furnish, 2 Corinthians, 341; Thrall, II Corinthians, 451.

${ }^{19}$ Beale and Webb, as has been observed, recognize the Servant (correctly) as the referent in Isa 49:8 and Paul as the referent in 2 Cor. $6: 2$. It should be noted that the quotation of $6: 2$ is a verbatim quotation of the LXX (Christopher D. Stanley, Paul and the Language of Scripture: Citation Technique in the Pauline Epistles and Contemporary Literature [SNTSMS 74; Cambridge: CUP, 1992], 216-217). I am not persuaded that Paul's use of the OT is bound to the LXX, a very slippery term in and of itself. Richard Bauckham has argued in his reading of Acts 15 that the early Christians (Jewish Christians) worked with both Greek and Hebrew texts as well as their own translation of Hebrew texts. Thus to argue for hermeneutical signifiers on the basis of Paul's alteration of the Vorlage is a slippery business, especially when the Vorlage we are dealing with is not necessarily a static entity as is often expressed with the term LXX. See Seitz, Figured Out, 41-42. 
this point it should be noted that within Isaiah 49 the referent of these second person pronouns is "the one deeply despised and abhorred by the nations" (Isa 49:7). The identity of this figure is the Servant of the second "servant song." This identification has led certain scholars to the conclusion that Paul identifies himself with the oov and oor of the Isaianic quotation. ${ }^{20}$ To read the quotation in this particular light-Paul is the Servant- presses beyond Paul's own explanation in $6: 2 \mathrm{~b}$. The referent of the second person pronoun is not the central concern Paul is dealing with. Though Lambrecht makes a convincing case that Paul reads the oov/oor ecclesiologically, this is at best a peripheral issue at this point. ${ }^{21}$ Paul tells the readers in $6: 2$ his purpose of

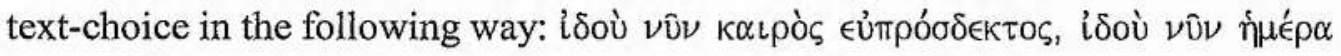
$\sigma \omega \tau \eta \rho i \alpha \varsigma$.

Paul's concern in this particular passage is his emphasis of the eschatological

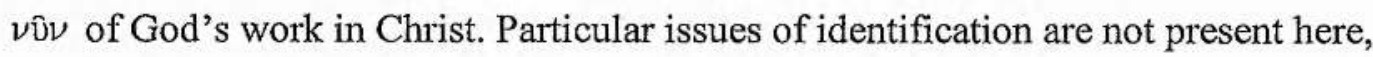
though the work of the Servant looms largely in the background as we shall see. ${ }^{22}$ What is undeniably present is the larger universalistic vision of God's salvation for both Israel and the nations, a vision both Paul and Isaiah share. Paul is revealing to his listeners their privileged position in God's eschatological, climactic redemption, and no other OT book serves Paul's purposes better than Isaiah. The overlap between Isaiah and Paul are so great that Westermann says, "The time of service is past, that of salvation is dawning. When Paul took over these words of v. 8 and used them in II Cor. 6.2 , he gave them the exact sense that they have here." ${ }^{23}$ What Isaiah alluded to

\footnotetext{
${ }^{20}$ As has been observed in Beale and Webb, see chapter 2. Lambrecht ("The Favorable Time," 386) finds this reading a "hypothetical construction." Lane observes that Paul's use of "prophetic call" language as found in Gal 1:15ff and 2 Corinthians "indicates that he has been called to the prophetic office" (William L. Lane, "Covenant: The Key to Paul's Conflict with Corinth" in TynBul 33 [1982], 7). The parallel status of the OT prophet and the NT apostle is affirmed. For example, Paul's allusions to Isaiah and Jeremiah in Gal 1:15 do not necessarily reflect Paul's identification of himself with either Jeremiah or Isaiah's Servant. Rather, Paul is placing himself in the line of prophets used by God in his redemptive action. This also makes Donaldson's affirmation of the possibility that Paul thought of himself as the Servant, "full stop," on the basis of his quotation in 2 Cor 6:2 untenable (Donaldson, Paul and the Gentiles, 254). Donaldson claims that Paul does not cite Isaiah 49 in reference to Christ's suffering but in reference to his own mission (254). Again, this presents a false disjunction between Paul's mission and the significant and foundational role Christ's suffering played in Paul's mission (this intertwining relationship is demonstrated in Paul's thought in 2 Cor. 5:14-6:10). It also fails to take into account the Isaianic allusions in 2 Cor 5:14-21 (especially 5:21) which, as will be argued, refer to the suffering Servant of Isaiah 53. The reality of God's initiative by means of the Christ to remove sins, and Isaianic concept, is at the very heart of the message of reconciliation.

${ }^{21}$ Lambrecht, "The Favorable Time," 381-381.

${ }^{22}$ A. T. Hanson states, "Paul would certainly understand this passage (Is 49, 1-8) as applying primarily to Christ, the original servant" (The Paradox of the Cross of Christ in the Thought of St Paul [JSNTSS 17; Sheffield: Sheffield Academic Press, 1987], 56).

${ }^{23}$ Claus Westermann, Isaiah 40-66 (London: SCM Press, 1969), 215.
} 
as a coming day - a day centered on the work of the Servant-is for Paul a present day. $^{24}$

Beyond this eschatological reading of Isa 49:8 per se, Paul seems to be doing more with this quotation. It has been previously claimed that Paul's thought in 2 Corinthians 3 is undergirded by the Exodus narrative itself. ${ }^{25}$ Similarly, Paul's thought in 2 Cor 5:14-6:10 centers around the narrative movement of Isaiah 40-66's canonical voice. This will be demonstrated in due course. Suffice it to say at this point that Isaianic allusions in 5:14-21, coupled with Paul's own particular defense in light of his suffering in 6:3-10, hover around Paul's quotation of Isa. 49:8. Thus 2 Cor 6:2 serves as a bridge holding these two pericopai together. Borrowing from Bruce Longenecker's imagery, 2 Cor 6:2's Isaiah quotation is the tip of the iceberg revealing the passage's underlying Isaianic logic. ${ }^{26}$

Paul's deep reflection on the redemptive drama of Isaiah 40-66 can be summarized with Paul's statement in 2 Cor 6:2, "now is the day of salvation." Paul's quotation of Isa 49:8, coupled with echoes in the preceding chapter, is an invitation into the redemptive drama found in Isaiah 40-66. Paul not only reflects on the Isaianic message as found in Isaiah 49 but draws his reader into the larger narrative of Isaiah 40-66 - a redemptive drama that centers on the person and work of the Servant and the subsequent servants of the Servant. Paul is not using Isa 49:8 in an ad hoc fashion nor is he identifying himself as the referent of the oou and oo of Isa $49: 8$ or 2 Cor $6: 2$ (contra Beale). Rather, Paul is drawing his readers to the conclusion that the present era is the climax of God's salvific eschatological work and inviting the reader into the larger redemptive drama of Isaiah 40-66. It follows, therefore, to explore the canonical movement of Isaiah 40-66's own voice seeking to highlight this section's key figures and theological movement.

\footnotetext{
${ }^{24}$ Traces of this eschatological thought pattern of Paul are found in 2 Cor 1:19-22. Paul, alluding to a specific conflict between himself and the Corinthians, portrays God as the faithful One who never draws back from his promises. Paul's radical Christocentrism draws the conclusion that all the promises of God are $v \alpha i$ in Christ $(1: 20)$. Though Paul may be alluding to promises found elsewhere in the Second Temple period (see Thrall, II Corinthians, 148), we are assured Paul has in mind the OT salvific promises of God or God's covenant promises. For Paul, the eschatological climax of God's redemptive purposes have found their "yes" in Christ. See also Martin, 2 Corinthians, 27. Furnish (II Corinthians, 147), following Thüsing, states that Paul does not say Christ is the "Yes," but that God's promises have their "Yes" in Christ. Furnish is warning the reader against a static view of God's promises in Christ in view of the ongoing "event" at work in the life of the community by the Spirit. Though Furnish's warnings are heeded, there is no reason the interpreter cannot say that Christ is God's eschatological "Yes."

${ }^{25}$ Hafemann, Paul, Moses, 191-195.
} 


\section{The Redemptive Drama of Isaiah 40-55: A Larger Narrative Reading}

The prophets had a "queer way of talking," says Luther. ${ }^{27}$ Most students of the prophetic literature find solidarity with Luther on this score as they enter into the mine-field of interpretive issues in Isaiah. Those difficulties are especially related to questions of historicity - behind the text issues - although, the interpreter is by no means "problem free" when it comes to "in the text" questions as well. The tension between synchronic and diachronic readings of Scripture comes to the foreground in this discussion. The quest for the "historical author" of Isaiah has led to numerous options for historical reconstructions which subsequently force a particular reading of Scripture, e.g., Isaiah 40-55 must be read as an exilic text written in Babylon. Brevard Childs's programmatic efforts with his canonical approach have brought to the attention of today's scholars the importance of both of these aspects of inquiry. For Christian doctrine and biblical theology, however, synchronic readings of Scripture, or reading the text in its final form, takes precedence. ${ }^{28}$ Childs has also, in the view of this author, effectively argued for a nuanced understanding of the text in its final canonical form, that is, by nature of a final editing of the texts the initial Sitz im Leben is altered as the text is received into its final canonical form. Therefore, authorial intent is in some measure defined by canonical intent. ${ }^{29}$

This study will seek to live within Childs's program of understanding the text's intention within its canonical form and shape, instead of allowing historical-

\footnotetext{
${ }^{26}$ Narrative Dynamics in Paul: A Critical Assessment (ed. B.W. Longenecker; Philadelphia: Westminster/John Knox Press, 2002).

${ }^{27}$ Christopher R. Seitz, Word Without End: The Old Testament as Abiding Theological Witness (Grand Rapids: Eerdmans, 1998), 118.

${ }^{28}$ Conrad states "Childs's canonical approach has been offered more recently as an alternative to the biblical theological movement. It has the major weakness, however, of dehistoricizing the Bible completely, so that the Bible as a canonical witness of the community of faith has been decontextualized" (Reading Isaiah [Minneapolis: Fortress Press, 1991], 159-160). Conrad's statement does not do justice to Childs's more nuanced understanding of the relationship between the diachronic and the synchronic. One of the criticisms of Childs is that he wants to makes his cake and eat it to so to speak, that is, he wants to affirm historical-critical conclusions coupled with his emphasis on the final form. See Mark Brett, Biblical Criticism in Crisis: The Impact of the Canonical Approach on Old Testament Studies (Cambridge: CUP, 1991). Conrad's particular reading of Isaiah is in line with the new reader-response movement and should be dealt with on its own terms. With that said, his critique of Childs misses the mark in understanding Childs's very sophisticated approach to the relationship between diachronic and synchronic approaches to the text. See Brevard Childs, "Retrospective Reading of the Old Testament Prophets," in ZAW 108 (1996), 376-377; Brevard Childs, "The Canoncial Shape of the Prophetic Literature," in Int 32 (1978): 47; Jože Krašovec, Reward, Punishment, and Forgiveness: The Thinking and Beliefs of Ancient Israel in the Light of Greek and Modern Views (VTSupp 78; Leiden: Brill, 1999), 8-10.

${ }^{29}$ Seitz, Word Without End, 80-82.
} 
critical questions - such as author, date, provenance, original audience, etc - to function in a hegemonic relationship over canonical concerns that focus on the text in its final form. Also, larger narratival readings of Isaiah 40-66 will surface in our study as opposed to more myopic examinations-though pertinent exegetical issues will not be avoided. ${ }^{30}$ To read Isaiah 40-66 strictly with a historical lens will not do justice to the canonical shape of the text itself with its theological and eschatological significance.

\section{3.a The Larger Narrative of Isaiah 40-55}

The reader of Isaiah 40-55 is lured into a dramatic world of a wayward, disillusioned people, a covenant-keeping God, and a program for God's redemption of his people and the nations through the work of a figure who embodies the vocation of Israel, namely, the Servant. Even if not working with any particular form-critical concept of "liturgical drama," the reader of Isaiah recognizes the dramatic elements within Isaiah $40-55 .{ }^{31}$ The narrative world of Isaiah 40-55 (66) is a world heightened by the use of evocative imagery and poetic language with a perlocutionary force of eliciting hope for God's "new thing" among his people and the nations, subsequently leading to "repentance." 32

What is striking about Isaiah $40-55(66)$ is the apparent silence of the material on the historical situation of the book's original composition. It has been assumed by much Isaianic scholarship that Babylonian exile backdrops the thrust of Isaiah 40-

\footnotetext{
${ }^{30}$ See Christopher Seitz, "Isaiah and the Search for a New Paradigm," in Word Without End (Grand Rapids: 1998), 113-129. The importance of the larger narrative of Isaiah 40-55 (66) for early Christians is expressed by Bauckham (God Crucified, 47), "For the early Christians, these chapters of Isaiah, above all else, were the God given account of the significance of the events of eschatological salvation which they witnessed and in which they were involved."

${ }^{31}$ Klaus Baltzer's new commentary on Isaiah 40-55 absorbs the message of Deutero-Isaiah into a "liturgical drama." Though Baltzer, from a form-critical perspective, would observe other literary genres at work in Isaiah 40-55, his program of reading designates "liturgical drama" as the overall genre encompassing the sub-genres within Deutero-Isaiah. The language of this drama is the heightened language of "poetry," and the term "liturgical drama" is meant to "bring out the proximity to worship and the cult" (Deutero-Isaiah [Minneapolis: Fortress Press, 2001], 7). Baltzer (DeuteroIsaiah, 15-18) adds that this phenomena was a part of ANE cultic worship in Bablyonia, Egypt, and surrounding provinces. The liturgical drama of Isa 40-55 involves several basic scenes: 1) The Throne Scene; 2) Lawcourt Scenes; 3) Battle Scenes; 4) Scenes with Artisans; 5) Marriage; 6) Movements, Procesions, Pompa; 7) Hymns-Music, Mime, and Dance; 8) The Servant of God Texts. John Eaton purposed a similar form-critical model for Isaiah 40-55 arguing that Deutero-Isaiah was based on a liturgical-royal feast connected to the Davidic monarchy (Festal Drama in Deutero-Isaiah [London: SPCK, 1979]).

${ }^{32}$ For an interesting proposal for the ways in which speech-act theory may inform our reading of the prophets see Walter Houston, "What did the Prophets Think They Were Doing?" in This Place is Too Small For Us (ed. R. P. Gordon; Winona Lake: Eisenbrauns, 1995), 133-153.
} 
$55 .^{33}$ In short, God is calling his people out of Babylon back to Israel, i.e. the New Exodus. ${ }^{34}$ C.C. Torrey could write in the 1920 's, "Few conclusions reached by modern Biblical scholarship would receive more general assent than the following in regard to chapters 41-48. They were written in Babylonia, in the sixth century B.C., near the close of the so-called 'Babylonian Exile'."35 Torrey responds to the consensus by asserting the exilic concern of Second Isaiah is not strictly Babylonian exile but the calling back of God's people from the dispersed regions of the ANE. ${ }^{36}$ With a more provocative spirit - which may have lost a hearing for Torrey-Torrey comments on Isaiah 49:13 in the following way:

"Who are his people? The question might seem to be superfluous, seeing that the prophet himself has just been telling us, with impressive emphasis and in unequivocal terms, that God's children from every race and region on earth are intended. But no; our commentators, one and all, refuse to take the prophet at his word. They insist that the 'prisoners are the exiles in Babylon'" (emphasis mine). ${ }^{37}$

Torrey put his finger on the perpetual problem of modern Isaianic scholarship. A

Babylonian background for the reading of Isaiah has forced interpreters to settle for a myopic, exilic reading of the book. Though Torrey may not have used this terminology, for some modern Isaianic interpreters the sensus literalis has been collapsed into the sensus historicus. ${ }^{38}$

\footnotetext{
${ }^{33}$ On the complexities of "exile" as history and ideology see, Leading Captivity Captive: 'The Exile' as History and Ideology (JSOTSupp 278; ed. L.Grabbe; Sheffield: Sheffield Academic Press, 1998).

${ }^{34}$ This reading of Isaiah 40-55 sets the tone for Webb's work Returning Home. The classic example of a form-critical reading of Isaiah 40-66 is Claus Westermann, Isaiah 40-66, OTL (London: SCM Press, 1966). An example, from a plethora of examples, of an overly historical reading of Isaiah 40-55 see Kapelrud, "The Main Concern of Second Isaiah," in VT 32 (1982): 50-58. Kapelrud argues for three main concerns in Isaiah 40-55. They are as follows: 1) Consolation; 2) Salvation and Redemption; 3) Theodicy: YHWH did not fail. Commenting of Isa 43:14-15, Kapelrud (53) states, "There is no doubt about the kind of salvation here: it is deliverance of the people from their oppressors in Babylon. Without doubt, this particular passage is dealing with deliverance from Babylon. However, to extend this thought pattern to the entirety of Isaiah $40-55$ so that "deliverance from their captivity in Babylon...[is] the dominating feature" (53) of the theme of salvation and redemption in Isaiah 40-55 with the result that "salvation first and foremost means release from captivity" (54) does not do justice to the material itself. For Isaiah's redemptive scheme is deeply rooted in Israel's plight of rebellion and sin coupled with God's radically new method of dealing with this problem of Israel. What Babylonian captivity signifies is the much deeper issue of Israel's inability to keep covenant with God, i.e., sin and their need of forgiveness.

${ }^{35}$ C.C. Torrey, The Second Isaiah (Edinburgh: T\&T Clark, 1928), 20.

36 "In the time of Second Isaiah the 'exiles,' i.e., Jewish emigrants from the homeland, were in every quarter of the known world" (Torrey, The Second Isaiah, 63).

${ }^{37}$ Torrey, The Second Isaiah, 116. J.D Smart has also objected to an exilic provenance for Isaiah 40-55 (History and Theology of Second Isaiah [Philadelphia: Westminster, 1965], 20-33).

${ }^{38}$ Our analysis of Isaiah 40-55 does not presuppose a Duhmian tri-partite view of Isaiah, e.g. 1-39, 4055, 56-66. In fact, Isaiah 40-66 will be treated in its final form. As Seitz states, "The provenance of these chapters has become increasingly literary and scribal and anonymous, making use of the terms
} 
Brevard Childs and Christopher Seitz have both recently published commentaries on Isaiah. ${ }^{39}$ Both are aware of the dangers of allowing "behind the text" issues to dominate the floor. Seitz remarks that "it is significant to note, and often is not sufficiently noted, how content these chapters are [Isaiah 40-66] to work with a low degree of historical reference." ${ }^{40}$ Thus Seitz concludes, "Then the constraining of the literature into some exilic context seems both unnecessary and less plausible, both on literary and on historical grounds." ${ }^{41}$ The assumption that Isaiah $40-55$ is set in the context of the Babylonian exile and should be read in this light alone has tended to skew a theological reading of Isaiah 40-55 which emphasizes God's new and mighty eschatological act of redemption for both Israel and the nations. ${ }^{42}$ For as Isaiah is at

'Deutero' and 'Trito-Isaiah---except as literary designations-nostalgic simplification" (Christopher Seitz, "Isaiah 40-66" in New Interpreters Bible, Vol. VI [Nashville: Abingdon Press, 2001], 314).

${ }^{39}$ Brevard Childs, Isaiah, (OTL; Louisville: Westminster John Knox, 2000) and Christopher Seitz, "Isaiah 40-66."

${ }^{40}$ Seitz, "Isaiah 40-66," 315.

${ }^{41}$ Seitz, "Isaiah 40-66," 316. Seitz gives special attention to the assumed response from critics regarding the mentioning of Cyrus in Isaiah 45:1. Seitz concedes the Isa 45:1 does not appear to be an interpolation but is closely related to the contextual argument. However, Seitz does not recognize the Cyrus statements as a necessary inference of a Babylonian provenance or strictly Babylonian exilic reading. In actuality, the typological thrust of Cyrus is grounded in the earlier depiction of Assyria (Isa 10:5). Theologically, Cyrus stands as a "second Pharaoh" surrounded by "new exodus language" who observes the new, mighty acts of God (Seitz, "Isaiah 40-66," 315). In his discussion of Cyrus, Seitz could very well have had von Rad in mind as his interlocutor. Gerhard von Rad, Old Testament Theology, Vol II (transl. D.M.G. Stalker; San Francisco: Harper and Row, 1965), 238-240.

${ }^{42}$ Without doubt, the role of the nations in Isaiah 40-66 is a deeply complex issue. One's particular conclusions in the debate are at least informed, if not slightly determined, by certain theological or historical commitments. The most recent article on the subject is by Joel Kaminsky ("The Concept of Election and Second Isaiah: Recent Literature," in BTB 31 [2002]: 135-144). Kaminsky traces the debate from Rowley to Levenson as he challenges a certain paradigm of thinking that espouses the Jewish religion as particularistic and Christianity as universal. Kaminskly ("The Concept of Election," 136) argues that both Christianity and early Judaism are in a sense particularistic. From this discussion, Kaminsky moves to Second Isaiah. Two groups of scholars arise in the conversation, those who think Second Isaiah is universalistic and those who find it nationalistic (139). Kaminsky does not believe a consensus will be reached at present (that is on Second Isaiah), however, he does press the need for a better understanding of "particularity." Kaminsky's concern in the article, and this becomes more obvious as one reads, is not a better understanding of Second Isaiah's view of the nations and Israel per se but of the wrongheaded thinking of "universalism is all good and particularity or nationalism is all bad" (140). Thus, Kaminsky's article is helpful on the theological front as Judaism and Christianity deal seriously with their own particularity in a pluralist society and ideology that would seek to blunt all edges of particularity (142-143). Isaiah's own voice on the matter needs to be carefully explored. Gelston has taken seriously those scholars who challenge a universalism in Isaiah 40-66-e.g. Orlinsky and Whybray-while at the same time he affirm the universal implications of Second Isaiah. Isa 45:2025 "strongly suggests that the survivors are Gentiles themselves, worshippers of idol-gods, who are shown not to be real gods precisely because of their inability to save" (A. Gelston, "Universalism in Second Isaiah," in JTS 43 [1992]: 387). Gelston challenges Whybray's tortuous exegesis of Isa 45:22 concluding that "The invitation to 'all the ends of the earth' is to turn to YHWH and be saved, because he is the only real God" (389). Gelston affirms a universalism in Isaiah 40-55 that contains three strands, 1) the affirmation that YHWH is the only true God, 2) This truth will be recognized by the Gentile nations no less than by Israel, with the corollary that they will submit to him and acknowledge his universal rule, and 3) Nowhere does the prophet affirm that all will avail themselves of this offer (396); see also Childs, Isaiah, 356. Gelston (397) concludes, "I still believe what I wrote in 1965 to be 
pains to tell us, "Forget the former things; do not dwell on the past. See, I am doing a new thing!" (Isa 43:18-19a). ${ }^{43}$ Thus, "To read the literature on its own terms is to respect this eschatological message and its capacity to transcend historical reconstructions." ${ }^{44}$

Indeed, within Isaiah 40-66 one senses the tension between the redemptive acts of God in the past and those about to take place in the future. ${ }^{45}$ Isa $46: 9$ calls on

true: 'the prophet discerned in moments of high vision the glorious fact that Yahweh's salvation was for all the world, while at other times he sank back to a more traditional and superior attitude towards the Gentiles.' It seems to be the case that this prophet recognized that the corollary of his conviction that YHWH was the only real god was that he was also 'God of all the earth' (54:5)." Van Winkle seeks to resolve the tension between universalism and nationalism by observing "that for DeuteroIsaiah the salvation of the nations does not preclude their submission to Israel" (Daniel Van Winkle, "The Relationship of the Nations to Yahweh in Isaiah xl-1v," in VT 35 [1985], 457); see also Pao, Acts and the Isaianic New Exodus, 226-227. Childs, commenting on Isa 49:24ff, keenly addresses the issue of nationalism vs. universalism with the following: "Yet it is highly misleading to set up a polarity between passages allegedly universalistic and those of ethnic narrowness. Much turns on the specific issue at stake in the oracle. If the prophet is addressing the scope of God's salvific will toward his creation, the free inclusion of the nations is an integral part of the prophet's message. However, if the issue turns on rival claims of power and authority exercised by the mighty and powerful rulers of the world, then the harshest possible rejection of their pretensions is made. Yahweh alone is Lord and Redeemer, who tolerates no rival either on heaven or earth" (Childs, Isaiah, 392-393). Seitz affirms both the centripetal and centrifugal aspects of Israel's fulfilling of the covenant with Abraham. Seitz conclusion needs to be stated in full, "The servants who suffer in imitation of their master, the one called to be the Israel after God's own heart in chapter 49, are separated from their persecutors within the household of God. The categories Israel and nations, servant and goyim, are not undone in God's final missionary act of conjoining. But both undergo massive transformation, within what the prophet can call only a new creation, a new heaven and earth. The end of Isaiah returns to the beginning and speaks of a new day and a new created order of affairs. The ending vision is what one might call the eschatological completion of God's missionary act: His willed and sovereign intention to put what created humanity makes awry good and in full accordance with a design nothing in heaven and earth can thwart. He will get his way with his world, through the plan of election and its final transformation through the suffering and death of his servant Israel" (Seitz, "The Old Testament, Mission, and Christian Scripture," in Figured Out, 156). Seitz's continued reflection on the implications of his thought for understanding the New Testament is important to observe (156-157). To sum up this complex matter, Isaiah 40-66 is not at all entirely clear as to the exact relationship between Israel and the nations. With that said, it is affirmed with Seitz that Isaiah is painting an eschatological picture of God's new redemptive act for both Israel and the nations that can be called nothing other than a new creation (Isa 65:17). Are the nations subsumed under Israel or incorporated into Israel? This seems to fit with Paul's understanding, e.g. Rom 9-11, yet, Isaiah is not perfectly clear on this score. It is enough for our purposes to affirm the universal implications of God's new redemptive act while at the same time affirming the fact that not all will embrace this invitation. Also, from a Christian theological standpoint, a retrospective reading of Isaiah in light of the universal implications of the gospel would be a fair understanding of the natural extension of Isaiah's figural sense. See also Walter Zimmerli, The Old Testament and the World (London: SPCK, 1976), 130, 136; G. I. Davies, "The Destiny of the Nations in the Book of Isaiah," in The Book of Isaiah (BETL 81; Leuven: Leuven University Press, 1989), 93-120; Brevard Childs, Old Testament Theology in a Canonical Context (Philadelphia: Fortress Press, 1985), 103-107.

${ }^{43}$ The "former things" / "new things" paradigm of Isaiah 40-66 is in no small measure the catalyst for the New Testament's particular emphasis on Isaiah 40-55 (66), or God's new, eschatological redemptive act. See Bauckham, God Crucified, 47; Seitz, Figured Out, 112-113.

${ }^{44}$ Seitz, "Isaiah 40-66," 321.

${ }^{45}$ Zimmerli gives apt insight into the traditum and its reception/use by Israel's prophets. "Prophetic proclamation thus shatters and transforms tradition in order to announce the approach of the Living 
God's people to remember the "former things" whereas verses such as Isa 43:18 seem to direct the reader to the antithesis of $46: 9$, "Do not remember..." The continuity between the past and the future redemptive acts of God are based on the eschatological intervention of God into history to redeem his people (e.g. the Exodus). However, a reliance on the past acts of God without a forward looking glance renders the people of God inoperative. The past roots the reality of God's redemptive framework, and the future is the place in which God will act again on his people's behalf, yet, in Isa 48:6 one finds the emphasis on the creative novelty of God's new redemptive act that is not typologically present in the past but "created now, not long ago" (Isa 48:6). Thus, God's "new act" of redemption takes central stage in the development of the redemptive drama.

Though our reading of Isaiah 40-66 may be labeled "theological," this does not take away from the fact that our study is committed to the final form of Isaiah 40 66 and its own discrete witness. It is not found persuasive that a reconstructed historical setting determining the lens through which the book is read is either profitable or for that matter possible on textual grounds. In short, the text is loudly silent regarding its own empirical, historical setting.

The brittle quality of the present literary structure only confirms the basic theological point that eschatological history, that is God's time, cannot be smoothly combined with empirical history, nor can the two be cleanly separated...The hermeneutical point to emphasize is that for Isaiah history is understood in light of prophecy, not prophecy in the light of history...These approaches fail to understand that prophetic eschatology is not an unmediated derivative of empirical history, but of a different order of divine intervention which is only dialectically related to temporal sequence. ${ }^{46}$

We are led to believe that the canonical intention of Isaiah 40-66 is eschatological in flavor. That is, the thrust of Isaiah 40-66 is forward looking, eliciting an eye of hope toward the new redemptive act God is about to do. ${ }^{47}$ To read Isaiah canonically, as the

One" (Walther Zimmerli, "Prophetic Proclamation and Reinterpretation," in Tradition and Theology in the Old Testament [ed. D. A. Knight; London: SPCK, 1977], 100).

${ }^{46}$ Childs, "Retrospective Reading," 373-375.

${ }^{47}$ Hanson states, "While denying neither the complex element in theological hermeneutics nor the complexities of the enterprise, I believe that all biblical interpretation must begin with a solid grounding in study of the historical setting (s) and meaning (s)" (Paul D. Hanson, "The World of the Servant of the Lord in Isaiah 40-55," in Jesus and the Suffering Servant: Isaiah 53 and Christian Origins [ed. W. H. Bellinger and W. R. Farmer; Harrisburg: Trinity International Press, 1998], 10). One senses the concern Hanson is seeking to combat, that is, a free-for-all in our "theological readings" of the texts with no connection to the historical material. It does seem, however, that Isaiah 40-66 within its own "plain sense" voice is forcing the reader beyond questions related to the establishing of 
continuing Word of God that speaks, is to take into account this theological locale as the intention of the text as witness to something beyond itself. In Isaianic terms a new creation. Our attention necessarily turns to the central figure of Isaiah's redemptive message, that is, the Servant.

\section{3.a.i The Servants Central Role in the Isaianic Drama}

Isaiah 40-55 (66) begins with the eschatological call of comfort to God's people (ציאנר Isa 40:1). ${ }^{48}$ This call of divine comfort signals the beginning of a new era of salvation and, within the narrative world of Isaiah 40-55 (66), this reality is dawning. ${ }^{49}$ The divine comfort of Yahweh heralded in 40:1 is intimately connected to the forgiveness of sins (Isa 40:2), a key aspect for our reading of Isaiah 40-55 (66). The beginning of chapter 40 is in a sense the line of demarcation between the former things in Isaiah 1-39 and the new things about to take place in Isaiah 40$66 .^{50}$ The force of Isaiah 40:1-11 does not lie in a form-critical "call narrative" presupposing the divine call of a new prophet deemed "Deutero-Isaiah". 51 Again, the text is silent regarding the personage behind the original address. Rather, the force of 40:1-11 is located in its intertextual linkage with Isaiah 6 . As the initial Isaianic call was a commissioning to a prophetic ministry of judgment, of which the Lord's word was vindicated as true; so to will the word of the Lord be validated in the new era, an era assuring divine comfort. ${ }^{52}$ The highlighted dramatis persona of Isa 40:1-11 is not

historical realities behind the text. Isaiah is an eschatological text pointing beyond itself as the prophetic word of the Lord.

${ }^{48}$ Note the intertextual connection with Isa 12:1.

${ }^{49} \mathrm{Pao}$, Acts and the New Exodus, 41.

${ }^{50}$ Seitz, "Isaiah 40-66," 328; Figured Out, 112-113.

${ }^{51}$ See Westermann, Isaiah 40-66, 32.

${ }^{52}$ Childs, Isaiah, 295-296. Childs leans on Seitz's work "The Divine Council: Temporal Transition and New Prophecy in the Book of Isaiah," JBL 109 (1990): 229-247. Childs diverges from Seitz regarding the voice of Isaiah. For Seitz, the voice of Isaiah is relegated to the distant past and the message of the new is given by "various anonymous voices." Childs understands that Isaiah of Jerusalem is both the proclaimer of the "old things" and the "new things." "The message of the prologue is that, although the prophetic judgment has been fulfilled, Isaiah's word of future salvation is now about to be accomplished in the new things. The continuity between chapters 1-39 and 40ff. does not lie in the historical persona of Isaiah - in this Seitz is right-but rather in the word of God, faithfully proclaimed by Isaiah, which extends into the future and fulfills itself in the new things of which Isaiah had also spoken" (Childs, Isaiah, 297). In light of Seitz's work, "How is the Prophet Present in the Latter Half of the Book?" in Word Without End (Grand Rapids: 1998), 168-193, one wonders whether Childs has rightly read Seitz on this score. It seems Seitz has developed in his thinking on the presence of Isaiah in Isaiah 40-66. Seitz states, "To the question, How is the prophet Isaiah present in chs. 40-66? we would respond thus: in word in chs. 40-48 and in person in chs $49 \mathrm{ff}$. - but not by himself. Isaiah, together with his fellow 'servants the prophets' running all the way back to Moses, is represented by the servant who speaks up in ch. 49, reflecting on hard labor, futility, yet trust in the one who called from the womb" (Seitz, "How is the Prophet," 189). 
the historical personage behind the original setting of this divine revelation but the very word of God that "stands forever" (Isa 40:8). God is about to do a new thing, the surety of which is connected to the ever faithful and unchanging word of God.

Having with poetic force described the power and uniqueness of Yahweh (Isa

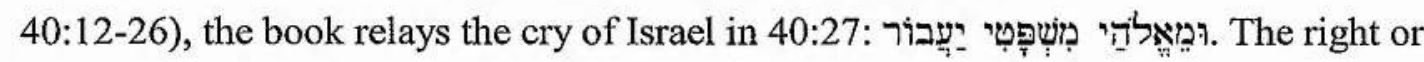
the justice of the people had, in their view, been disregarded by God. The initial response to this cry of desperation is a display of the greatness and indefatigable nature of their God who is quick to strengthen the weary whose hope is in him (Isa 40:28-31). This, however, is an indirect response to the question at hand. One is left in suspense with regard to the cry for פִ 40 40:27 until the beginning of the so-called "first servant song" in 42:1. ${ }^{53}$ The answer to Israel's cry for "justice" comes in a surprising twist of events as the Servant, the one in whom God has delighted and placed his Spirit, is revealed as the one whose vocation is inextricably linked with the bringing of מִ מִשְׁ to the nations. ${ }^{54}$ What becomes of central import in the development of Isaiah 40-55 (66) is the bringing of "justice" to the nations and the determinative role the Servant plays in this divine goal. From the outset of Isaiah 40-55 (66) the central role of the Servant begins to emerge.

Traditional form-critical studies of the "servant songs" have removed them from their context treating them as isolated pericopae. Duhm recognized the "servant songs" (Isa 42:1-4; 49:1-6; 50:4-9; 52:13-53:12) as interpolated oracles isolated from their context and not composed by "Deutero-Isaiah," "55 Thus the "servant songs" are

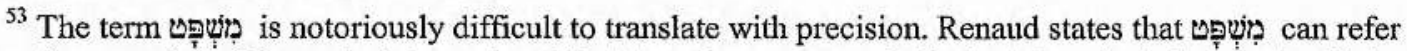
to "an act of deciding or judging; a legal decision; the contents of this decision; the judgment itself; the right (of an individual or a group); a statute; a bond; equity; that which is just and right; the law, commandment, or custom (most often in the plural)." (Thomas L. Leclerc, Yahweh is Exalted in Justice: Solidarity and Conflict in Isaiah [Minneapolis: Fortress Press, 2001], 105). Leclerc (Yahweh is Exalted, 108-109) has given detailed attention to the different ways מִ ị is used in Isaiah. In Isaiah

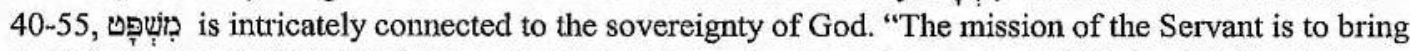
forth to the world YHWH's justice, that is, his just and unrivaled sovereignty" (Yahweh is Exalted, 110).

${ }^{54}$ See Childs, Isaiah, 324. Beuken's article is a programmatic statement for the ways in which the "servant songs" are related to the context of Isaiah 40-55 (W. A. M. Beuken, "MISPAT. The First Servant Song in Its Context," VT 22 (1972) 1-30; see also Klaus Koch, The Prophets Vol. 2: The Babylonian and Persian Periods (transl. M. Kohl, London: SCM Press, 1983), 137).

${ }^{55} \mathrm{H}$. H. Rowley, The Servant of the Lord and other Essays on the Old Testament (Oxford: Blackwell, 1952), 4-5. Rowley's work offers a detailed discussion regarding the theories of the "servant songs." See also, Christopher R. North, The Suffering Servant in Deutero-Isaiah: An Historical and Critical Study (Oxford: Oxford University Press, 1948); Tryggve N. D. Mettinger, A Farewell to the Servant Songs: A Critical Examination of an Exegetical Axiom (Transl. by F. H. Cryer; Lund: Bloms Boktryckeri, 1983); Harry M. Orlinsky, "The So-Called 'Servant of the Lord' and 'Suffering Servant' in Second Isaiah," in Studies on the Second Part of the Book of Isaiah (VTSupp 14; Leiden: Brill, 1977), 1-133.
} 
ex eventu oracles. Without tracing the tortuous historical development of these thoughts, today scholars are calling on readers of Isaiah to interpret the "servant songs" in light of their context or as inextricably linked to the overall message of the book. ${ }^{56}$ What one comes away with in this unified reading of Isaiah 40-55 (66) is the fact that the Servant is the central persona (as an extension of the work of God) in this drama of redemption. Within Isaiah 40-55 the development of the Servant theme climaxes with that most powerful of poems, the fourth servant song, Isa 52:13-53:12. In short, Isaiah's canonical form presses the reader to observe the central role of the Servant in the developing and revelatory event of redemption. Attention, therefore, will be given to the "servant songs" of Isaiah 40-55 in their context and not as isolated or interpolated songs.

\section{3.a.ii The "Servant Songs"}

\section{3.a.ii.1 42:1-4}

The cry from Israel for מִ מִ מִ is answered in 42:1-4 as God reveals his Servant as the means by which he will bring restoration of God's order in the world." ${ }^{, 57}$ Form-critical questions aside-is this a royal commissioning scene? - one observes a new scene emerging in the movement of the book. This new scene is noted by the particle 1 i which draws the spotlight onto the figure of the Servant as a central character in God's new redemptive scheme. Contextually, 42:9 makes the statement, "See the former things have taken place, and new things I declare..." The "new things" God is doing is linked to the personage of the Servant who is revealed in 42:1-4.

Questions related to the exact office of this Servant of God-prophet or king-are not explicated in this text. Rather, this emerging figure is defined by the term "servant" (עבר). In the OT this title was given to a range of people with differing social status - patriarchs (Gen 24:14); Levites (Ps 113:1); Prophets (I Ki 14:18); or Israel (Jer 30:10). ${ }^{58}$ Thus the particular office of the Servant is not revealed, nor need it be. For the Servant is revealed in his narrative identity, that is, by the "what" of his particular vocation. The Servant is God's elect, the one in whom God has delighted (42:1). His particular mission in this passage centers on his work as "bringer of

\footnotetext{
${ }^{56}$ See n. 48 for examples.

${ }^{57}$ Childs, Isaiah, 325.

${ }^{58}$ Seitz, "Isaiah 40-66," 362; Beuken, Deutero-Isaiah, 126-127; Childs, Isaiah, 324.
} 
justice" $(42: 1,3)$. Unlike the mighty Cyrus who "treads on rulers as if they were mortar" (41:25), this Servant of Yahweh is characterized as one who will not raise his voice and who will deal gently with those who are suffering and faint (42:2-3). ${ }^{59}$ Also, the Servant will not grow weary until his mission is accomplished, i.e., the bringing of justice on the earth and the establishment of his teaching even to the far corners of the world (the islands [42:4]).

Questions regarding the identity of the Servant are difficult and have perplexed scholars for some time. ${ }^{60}$ Historiographical concerns do not necessarily lend a helping hand in the identification of this Servant figure. The "cryptic, veiled language," according to Westermann, "is deliberate." ${ }^{61}$ On the other hand, Childs states "For anyone who takes the larger literary context seriously, there can be no avoiding the obvious implications that in some way Israel is the servant who is named in 42:1" (emphasis his). ${ }^{62}$ Childs's point is well taken and any identification of the Servant in this passage that is not linked to Israel would distort the larger narrative. Wilcox and Paton-Williams have raised a pertinent question pertaining to the very active role of the Servant and the very passive role of servant Israel. ${ }^{63}$ This paradox is not insurmountable, however. For what is presented in Isa 42:1-4 is the ideal picture of what Israel is to do and be. Israel's vocation is that of minister of justice and distributor of torah among the nations. The Israel found in Isaiah 40-55 (66), however, is a defeated, weary, and rebellious Israel (Isa 58-59) not capable of fulfilling its role. Wilcox and Paton-Williams insightfully state, "To summarize: there is a difference between the character of the servant with the first Servant Song and the character of servant Israel in chs. 40-48; but there is no difference of identity." ${ }^{64}$ They conclude by quoting Goldingay, "the picture of the servant [in 42:1-4] has become a role seeking

\footnotetext{
${ }^{59}$ Leclerc opines that the bruised reed and smoldering flax may refer to more than the exiles. "But it is also possible to see in it a reference to theose among the nations who have foolishly put their trust in their gods and idols." Leclerc points out that "reed" and "flax" can be used metaphorically of other nations (cf. Isa 36:6; $2 \mathrm{Kgs} \mathrm{18:21;} \mathrm{Ps} \mathrm{68:31;} \mathrm{Isa} \mathrm{43:17).} \mathrm{Leclerc,} \mathrm{Yahweh} \mathrm{is} \mathrm{Exalted,} 109$.

${ }^{60}$ Again, for a summary see Rowley, The Servant of the Lord; G. P. Hugenberger, "The Servant of the Lord in the 'Servant Songs' of Isaiah: A Second Moses Figure," in The Lord's Anointed: Interpretation of Old Testament Texts (ed. P. E. Satterthwaite, R. S. Hess, G. J. Wenham; Grand Rapids: Baker, 1995), 105-140; John D.W. Watts, Isaiah 34-66 (WBC; Waco: Word Publishers, 1987), 116-118.

${ }^{61}$ Westermann, Isaiah 40-66, 93.

${ }^{62}$ Childs, Isaiah, 325; see also Watts, Isaiah 34-66, 116-117.

63 "Israel is summoned to hear $(44.1 ; 46.3 ; 48.1,12)$, to see $(40.9 ; 41.11,15 ; 43.19)$, to remember $(44.21 ; 46.8,12)$, to take courage $(41.10,13,14 ; 43.1,5$ et al. $)$ and to bear witness $(43.10,12 ; 44.8)$ : there is nothing very active about this commission" (Peter Wilcox and David Paton-Williams, "The Servant Songs in Deutero-Isaiah," in JSOT 42 [1988], 87).

${ }^{64}$ Wilcox and Paton-Williams, "The Servant Songs,' 88.
} 
someone to fulfill it." ${ }^{65}$ In due course, attention will again be given to the identity of the Servant.

\section{3.a.ii.2 Isaiah 49:1-6}

Isaiah 49, as has been observed earlier, is a key chapter for our understanding of both Paul's reading of the dramatic narrative of Isaiah 40-55 (66) and also for our understanding of the development of the Servant theme in Isaiah's own canonical form. The actual parameters for the "servant song" are most likely Isa 49:1-6, though the Servant motif continues to 49:12. Undoubtedly, this "servant song" is a difficult one with which to deal. A series of questions are raised, especially regarding the identity of the Servant. Also it should be observed that within the narrative, the speaker in this section is the Servant himself. ${ }^{66}$

Without rehearsing the various form-critical suggestions for 49:1-6-e.g. thanksgiving, call narrative, or commissioning-it is noted that there is an apparent tension in the passage itself. For in 49:3 the Servant is called Israel, yet in 49:5,6 the Servant has a particular role toward Israel. Wilcox and Paton-Williams have thoroughly challenged the "Israel" of 49:3 as an interpolation theory. ${ }^{67}$ Therefore the interpreter is left with an apparent tension of sorts, "Is the servant Israel, or the prophet, or what?" 68

Beuken's proposal for our understanding of Isaiah 49:1-6, as explicated by Childs, is to place 49:1-6 "in the inner movement of the prophetic narrative extending from chapter 40 to chapter 55." ${ }^{, 69}$ One notes the parallels between 49:1-6 and 42:1-4, although a great deal has taken place textually between these two texts. Cyrus has come onto the scene as a type of God's making good on his promise (44:24ff, 45:1), and the Babylonian deities have been exposed as impotent before Israel's God (4647). It is recalled that in 42:1-4 Israel is given a specific role in the midst of this divine reordering of affairs; they are to establish justice on the earth and be a light to the nations-the first "servant song" 42:1-4. Yet Israel has not fulfilled her role in the

\footnotetext{
${ }^{65}$ op cit. Wilcox and Paton-Williams, "The Servant Songs," 88.

${ }^{66}$ Seitz argues that the actual authors of this discourse (assuming he is making the distinction between actual author and implied author) are the servants of the servant. Though the actual author is difficult to define textually, this theme of the "servants of the servant" will emerge as a key component in our reading of Isaiah and Paul in 2 Cor 5:14-6:13 (Seitz, "Isaiah 40-66," 424).

${ }^{67}$ For a positive appraisal of the interpolation theory see Westermann, Isaiah 40-66, 209. Wilcox and Paton-Williams, "The Servant Songs," 90-91; Seitz, "Isaiah 40-66," 429.

${ }^{68}$ Wilcox and Paton-Williams, "The Servant Songs," 89.

${ }^{69}$ Childs, Isaiah, 382.
} 
new exodus. "Hear you deaf; look, you blind, and see! Who is blind but my servant, and deaf like the messenger I send..." (Isa 42:18-19). In chapter 48 the stubbornness and rebelliousness of the people is rehearsed with strong language, "You were called a rebel from birth" (48:8). ${ }^{70}$ Within the narrative flow of God's redemptive drama, it becomes more readily available that the role Israel was given to perform as "light to the nations" was not being fulfilled nor would it be fulfilled by those who had been rebellious from birth. This contextual backdrop of Israel's calling as Servant yet persistence in rebellion shapes our reading and hearing of 49:1-6.

With the apparent failure of Israel to fulfill her role placed firmly in the context of 49:1-6, our attention turns toward 49:3, "You are my servant, you are Israel." 71 The options for understanding the function of "Israel" are fourinterpolation, vocative, appositive, or predicative. ${ }^{72}$ Recognizing the context, several recent interpreters have opted for the predicative. "Your are my Servant, you are Israel." 73 As previously observed, this interpretation fits well within the movement of chs. 42-48 and 49:5-6. Also, what begins to emerge in the development of the Servant theme is an individual taking the role originally designated for Israel. In autobiographical style, the Servant rehearses his frustration and weariness in delivering the message of the new exodus to the exiles, yet with proleptic insight Yahweh rehearses for the Servant his new role. Not only will he restore my people Israel ("is it too small a thing"); he will also be a "light to the Gentiles that you may bring my salvation to the ends of the earth" $(49: 6) .{ }^{74}$ Debates will rage over the exact personage behind this text, however, in eschatological fashion, Isa 49:1-6 anticipates

\footnotetext{
${ }^{70}$ One hears echoes of Ezekiel's allegory of the "whoring wife" loved from childbirth in Ez 16.

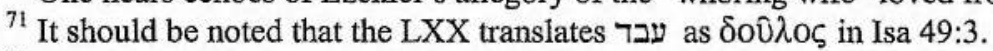

${ }^{72}$ Childs, Isaiah, 383-384.

${ }^{73}$ Wilcox and Paton-Williams, "The Servant Songs," 90; Seitz, "Isaiah 40-66" 429; Childs, Isaiah, 384.

${ }^{74}$ Gelston helpfully interacts with the difficulties of translating and interpreting both "light to the nations" and "salvation". Certain scholars-e.g. Whybray-have argued that "light to the nations" refers to the blinding and involuntary yielding of the nations to Yahweh. Gelston concludes that the parallel clause תור refers to more to illumination that blinding and-citing Van Winkle-42:16 and 54:7 refer to "light" as a figure of deliverance from darkness (Gelston, "Universalism in Second Isaiah," 393-394). שוד "שs also refers to "YHWH's successful and victorious intervention to save, which is announced in verse 5 as being already under way" (Gelston, "Universalism in Second Isaiah," 395). The question remains, however, as to the extent of this salvation. Does Yahweh intervene to save his own people, or all mankind? Gelston ("Universalism in Second Isaiah," 395) remarks, "That is has the wider dimension is suggested by the immediate sequel in verse 5, announcing that YHWH's 'arm will rule the peoples', and that the coasts and islands will wait in expectation for this intervention." Thus, Orlinsky's definition of שו" as "victory," "triumph," or "vindication" is "too narrow a definition of its semantic range to cover 51:5-6" (Gelston, "Universalism in Second Isaiah," 395).
} 
the Servant's taking of Israel's role as light to the nations with the ultimate goal of bringing "salvation" to the ends of the earth. ${ }^{75}$

The following verses (49:7-12) raise a host of questions regarding redactional layering, who is being spoken to, who is speaking? Obviously at 49:7 Yahweh interjects his own statement regarding the Servant's humiliation and exaltation (the conceptual linkage to $52: 13-53: 12$ echoes loudly). Within the narrative flow there is silence pertaining to the speaker for the Lord's identity. If the Lord is continuing to speak to the Servant, confusion is raised pertaining to the use of the second person singular ("you") in this section as compared to the first person singular in 49:1-6 ("me"). What is observed within the contextual flow is that Yahweh is continuing to speak to the Servant, but who adds this elaboration within the narrative at this point? The most interesting of proposals, and the one fitting best within the narrative flow of the larger redemptive drama of Isaiah 40-66, is that of Seitz. "Rather, it is an elaboration," so Seitz, "made by the servants, promising that God's intention with the servant will finally prevail." ${ }^{, 76}$ Seitz bases his reading on the conclusion of chapter 54 (v.17) which states, "This is the heritage of the servants of the Lord, and their vindication from me, says the Lord." "77 What is taking place is a backward looking at the suffering of the Servant who has become בְרִית לָּם

\footnotetext{
${ }^{75}$ Wilcox and Paton-Williams argue that the Servant called Israel is the prophet re-commissioned in this scene ("The Servant Songs," 92). Seitz has argued along similar lines in a more nuanced fashion. The Servant, for Seitz, is lining up within a tradition of prophets especially that of Jeremiah. "This servant's career picks up where Jeremiah left off, at the end of his career. That is, it is a mission based on all prior prophecy at its own potential end point and dissolution... This servant carries Israel's history with prophecy in him and, in so doing, is "Israel' in a very specific sense" (Seitz, "How Is the Prophet Isaiah Present," 188). Childs (Isaiah, 385) takes another nuanced view, "I am not suggesting that collective Israel has been replaced by an individual prophetic figure, say, by Second Isaiah himself. Such historical speculation misses the point of the text. The identity of the first person singular voice in 48:16 and 49:1-6 remains fully concealed. Rather, what is crucial to observe is that one, bearing all the marks of an individual historical figures, has been named Servant, not to replace corporate Israel-the Servant in Second Isaiah remains inseparable from Israel - but as a faithful embodiment of the nation Israel who has not performed its chosen role (48:1-2)." Whatever may lie behind the historical actuality of this text will continue to be debated. What can be learned from a textual standpoint is that in God's "new thing" of redemption he does not allow Israel's failure to hinder God's program of reconciliation, reconciliation not strictly for Israel (though definitely the case) but reconciliation with the "ends of the earth," humanity. Clements states, "Yet it still retains something of an expectation that Israel's election is an election for service to bring other nations to a knowledge of Yahweh." For further reflections on the role of Israel as "servant" to the nations see Ronald E. Clements, Old Testament Theology: A Fresh Approach (London: Marshall, Morgan \& Scott, 1978), 95-96. The means by which the Servant/Israel will bring salvation to the ends of the earth is by suffering - this becomes explicit in the fourth servant song. Thus, the accomplishment of the Servant's being a "light to the Gentiles" is based on his faithfulness to Yahweh, a faithfulness that takes form in obedient suffering. See Jon D. Levenson, The Death and Resurrection of the Beloved Son (New Haven: Yale University Press, 1993); Seitz, "Isaiah 40-66," 433, 469.

${ }^{76}$ Seitz, "Isaiah 40-66," 430.
} 
connection with the first servant song is a light to the nations and the restorer of Israel. The Servant is God's demonstration of covenant loyalty to both Israel and mankind.

Our attention, again, is drawn to $49: 8$, a verse that stands as an eschatological marker. As Childs remarks, "The phrase 'in an hour of favor' resonates with the 'but now' of v. 5 and speaks of the eschatological moment of salvation in God's time."78 Chapter 49 stands as a key marker in God's eschatological, redemptive drama. The text itself, within the narrative flow, is beginning to pressure the reader to recognize an individual who emerges as the one who embodies the vocation of Israel as light to the nations and restorer of Israel. In both the Servant's suffering and exaltation (49:7) Yahweh makes his "new thing" come about in the most provocative of fashions. Yet, we are reminded again and again that in spite of this provocative move by God, the reader is to expect something "new."

\section{3.a.ii.3 Isaiah 50:4-9}

The absence of the actual term "Servant" should not keep the reader from understanding this passage as a "servant song." 79 Westermann observes that this "servant song" is the easiest to understand. ${ }^{80}$ The genre of this pericope is that of a trust song or a psalm of confidence, the nature of which is a psalm expressing thanks for God's faithfulness in the midst of a lamentable position. Also, attention has been given to the connections between Jeremiah and the suffering Servant of Isaiah 50:4$6 .^{81}$ The speaker of this psalm of confidence is without doubt the Servant, as hinted at in $54: 10 .^{82}$

A theme often associated with the Psalms arises in this context, that of the innocent sufferer (cf. Ps. 22, 44, etc.). The Servant speaks of himself as one who has submitted fully to the will of his God resulting in suffering and humiliation. Yet, and this is the key point of the song, the Servant who suffers in innocence has "set his face like a flint" as one whose trust is unyieldingly in his Sovereign Lord (54:7-9). As Wilcox and Paton-Williams have observed, "In this song, the Servant is oppressed,

\footnotetext{
${ }^{77}$ See fuller elaboration on the "servants of the Servant" theme in chapter four.

${ }^{78}$ Childs, Isaiah, 386-387.

${ }^{79}$ Childs, Isaiah, 394; Wilcox and Paton-Williams, "The Servant Songs...," 93.

${ }^{80}$ Westermann, Isaiah 40-66, 226.

${ }^{81}$ Westermann, Isaiah 40-66, 227ff.; Seitz, "Isaiah 40-66," 436.

${ }^{82}$ Childs, Isaiah, 394; Alec Motyer, The Prophecy of Isaiah (Downers Grove: IVP, 1993), 398.
} 
yet obedient; obedient, yet oppressed." 83 Also, the Servant's portrayal as an individual is beyond the pale at this point in the narrative movement of Isaiah. ${ }^{84}$ Hints at the narrative identity of the Servant are now beginning to show. The Servant acts as one who is oppressed, yet in the midst of his suffering he is obedient to God's call - "be Israel for the world." Again, one observes within the narrative drama a coercion towards reading the developmental nature of servant Israel (the nation) being taken over by servant Israel (an individual). This is part and parcel of God's "new" redemptive action for Israel, and ultimately, for the nations.

\section{3.a.ii.4 Isaiah 52:13-53:12}

It would be hard to imagine a biblical text more revered and yet more debated within the history of the church than the fourth "servant song," Isaiah 52:13-53:12. ${ }^{85}$ Textual and literary questions abound, although, these questions are typically eclipsed by the larger question, "Who is the Servant?" 86 Under the auspices of both Beuken and Childs, and for purposes related to the nature of this study, diachronic issues-i.e., the redactional layers within the text-will be set aside so as to deal with the larger literary questions as found in the present form of the canonical witness. ${ }^{87}$

One senses within the narrative flow of Isaiah 40-55 the climactic nature of the poem of Isaiah 52:13-53:12. Within chapter 51 anticipation is built as the restoration of Zion is described as accomplished by the "arm of the Lord" (Isa 51:4). ${ }^{88}$ The sovereign reign of God is brought to the foreground as the people of God are encouraged to look to the heavens (51:6), and the promise of $51: 4$ is given to

\footnotetext{
${ }^{83}$ Wilcox and Paton-Williams, "The Servant Songs...," 93.

84 "When seen in the larger context of the narrative movement within chapters $40-55$, there is a clear transfer from Israel, the servant nation, to Israel, the suffering individual who now embodies the nation's true mission." Childs, Isaiah, 395. See also, Wilcox and Paton-Williams, "The Servant Songs...," 94.

${ }^{85}$ Janowski states the matter clearly, "Es gibt nur wenige religiöse Texte der Antike, die so folgenreich waren und doch so rätselhaft gebelieben sind wie die biblischen Überlieferungen vom ,leidenden Gerechten" (Bernd Janowski, "Er Trug unsere Sünden Jes 53 und die Dramatik der Stellvertretung," in Der leidende Gottesknecht: Jesaja 53 und seine Wirkungsgeschicte [ed. B. Janowksi and P. Stuhlmacher; Tübingen: J.C.B. Mohr, 1996], 27). See also John Sawyer, The Fifth Gospel: Isaiah in the History of Christianity (Cambridge: CUP, 1996).

${ }^{86}$ It should be noted that the complexities of this passage would not be done away with if the "corruptions" within the text were not present (Wilcox and Paton-Williams, "The Servant Songs...," 94-95; Childs, Isaiah, 411-412). For deeper analysis of textual questions see Baltzer, Deutero-Isaiah. Also, for a thorough review of the pertinent issues pertaining to the interpretation of Isaiah 53 see Henning Graf Reventlow, "Basic Issues in the Interpretation of Isaiah 53" in Jesus and the Suffering Servant, 23-38.

${ }^{87}$ Childs, Isaiah, 410.
} 
("my people") with the law and justice going forth to עַפְִים ("the peoples"). Those

addressed in $51: 4$ are the faithful who have heeded the injunction of $50: 10$ by

following and obeying the word of the Servant. Yet a transformation is taking place in the midst of God's "new" act of redemption. In an illuminating fashion, Childs comments on 51:4, "The effect of this promise is that the sharp line once separating Israel from the nations has been overcome, and the new people of God emerges as encompassing all those responding in faith to God." ${ }^{, 89}$ God's program of redemption has within it an overarching goal of reaching the nations (cf. 49:6).

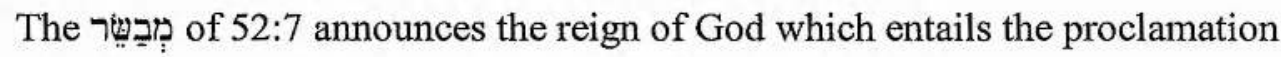
of peace, the bringing of good tidings, and the announcement of salvation. The following verse $(52: 8)$ makes it clear that $\mathrm{Yahweh}^{90}$ will return to Zion and his holy arm will be laid bare before all the ends of the earth $(52: 10){ }^{91}$ Therefore, when Yahweh returns to Zion "all the ends of the earth will see the salvation of our God" $(52: 10) .{ }^{92}$ The climactic fourth servant song follows closely to the thought line of Isaiah 52:8, that is, Yahweh's return to Zion.

${ }^{88}$ Literarily anticipation is elicited from the reader with the repeated use of עורירי ערירי $51: 8,17$; 52:1.

${ }^{89}$ Childs, Isaiah, 402. Childs (Isaiah, 404) continues this line of thought with his comments on Isa 51:9-11, "Yet it is crucial to recognize from the larger context of vv. 9-11 within chapters 50 and 51 that the people of God have continued to be defined as the new order of those who seek the Lord and identify with the obedient response of the servant."

${ }^{90}$ On the use of the term "Yahweh" see R. Walter L. Moberly, The Old Testament of the Old Testament: Patriarchal Narratives and Mosaic Yahwism (Minneapolis: Fortress Press, 1992), 5 n. 1. Moberly defends the use of "Yahweh" in elongated form but does not take this option himself.

${ }^{91}$ Reinoud Oosting comments on the poetic license taking place in 52:7-10 in which the watchmen of the city Jerusalem are looking for the return of Yahweh. For in this time, Jerusalem had no walls but was a ruined city. The import of Isaiah 52:8-Yahweh returns to Zion-is stated by Oosting in the following way: "They [the watchman/heralds] have noticed his kingly entrance into Zion. Zion/ Jerusalem herself, however, consists of ruins. Like the public of Deutero-Isaiah she still hesitates to acknowledge YHWH as king. Jerusalem's ruins have not yet become Zion again. Her watchmen, however, have lifted up their voice because before their eyes they see YHWH returning to Zion. In the book of Deutero-Isaiah they are the first who are mentioned to have eyes and who do see (cf. Isa 42:7; 43:8)" (Reinoud Oosting, "Returning to Zion: Isaiah 52:8 in light of Verbal Valency Patterns" in The New Things: Eschatology in Old Testament Prophecy; Festschrift for Henk Leene, [ed. F. Postma, K. Spronk, E. Talstra ; Maastricht: Uitgeverij Shaker Publishing, 2002], 166).

${ }^{92}$ In response to Webb's reading of Isaiah 52:11-12 as a "return from Babylon" text adopted by Paul in 2 Cor 6:14-7:1, our attention moves to the text itself (see extended discussion in the previous chapter).

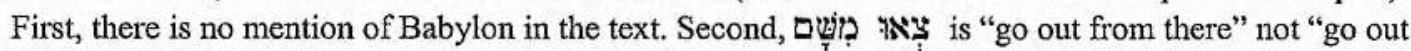
from here." The call given in this verse is closely related to the statement in 52:1 (..O Jerusalem, the holy city, the uncircumcised and defiled will not enter you again.). The tradition echoed in 52:11-12 is that of the first Exodus and those who carry the vessels are to flee those places (not necessarily a geographical locale--e.g. Babylon) where God's holiness is not honored. Unlike the fleeing in haste of the first Exodus, this fleeing will be done in full confidence of the Yahweh's going before them and protecting them as their rearguard. These particular verses are not dealing with a Babylonian geography but a call to holiness as elicited in 52:1-6. See Childs, Isaiah, 406-407; Motyer, The Prophecy of 
The building pressure of this new movement of God, in which his salvation will be seen by the ends of the earth, moves toward this fourth of the "servant songs." Isaiah 52:13 begins with the particle הִג which contains allusions to the first servant song, Isa 42:1-4. ${ }^{93}$ In this final "servant song" the Servant's mission is presented as accomplished. Within the narrative, Yahweh is the speaker of 52:13-15 and the Servant's exaltation and humiliation are rehearsed with intensely poetic language, such as, the Servant will be "raised and lifted up and highly exalted" says 52:13 (ירום

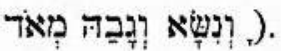

Wilcox and Paton-Williams observe, "Throughout Isa. 1-66, the adjectives 'exalted,' 'lifted up' and 'very high' are virtually technical terms, applied almost exclusively to Yahweh." 94 Wilcox and Paton-Williams tread lightly on this observation, "The implication is not necessarily that the servant is Yahweh, or even divine; but there is an implication here that the servant's work is Yahweh's work, and the language used to make the point is daring, to say the least." ${ }^{95}$ More needs to be said.

The most alerting intertextual reference in Isaiah which makes use of these adjectives (raised and exalted) is Isaiah 6:1 - "I saw the Lord seated on a throne, high and exalted." Richard Bauckham has drawn important conclusions from his observation of the intertextual link between Isa 6:1 and Isa 52:13. "The servant, in both his humiliation and exaltation, is therefore not a human figure distinguished from God, but, in both his humiliation and exaltation, belongs to the unique identity of God." ${ }^{, 96}$ Bauckham argues, speculating about God on the basis of God's narrative identity, that the Servant in his work and mission is actually a part of the very identity of the one God who is seeking to reconcile the world unto himself. It must not be missed that the work of the Servant as displayed in this climactic of sections is unequivocally connected to the work of Yahweh. This concept of narrative identity and the Servant will be returned to shortly.

Again, the prophet (narratively Yahweh) highlights the role the Servant plays toward the nations in Isa 52:14-15. The parallel of 52:14-15 to the previous servant

Isaiah, 421-422; Seitz, "Isaiah 40-66," 455. For a counter-reading see Gerhard von Rad, Old Testament Theology, Vol II, 246.

${ }^{93}$ Westermann, Isaiah 40-66, 258.

${ }^{94}$ Wilcox and Paton-Williams, "The Servant Songs," 95 . It is of interest to note the use of "behold" used by Yahweh for himself in 52:6, הִ.

${ }^{95}$ Wilcox and Paton-Williams, "The Servant Songs," 95.

${ }^{96}$ Bauckham, God Crucified, 51. 
song, 50:4-9, should not be missed, as the Servant is one who in his suffering appalled the "many" bringing a sense of disgust at his appearance. Yet the controversy in this introductory aspect of the poem is found in 52:15. What action does the Servant perform for the nations? In short, does the Servant "startle" or "sprinkle"? The answers to this question are complex for as Reventlow reminds us, "All these uncertainties are typical of poetry. Poetry thrives on allusions, on impressions which touch the feeling, never using explicit definitions, but rather hints referring to a knowledge hidden in the subconscious of hearers." 97

Childs argues that should be read "to startle" based on the following three issues: 1) The LXX reads "surprise," therefore we are more than likely dealing with semantic range and not textual variant; 2) This verb in the hifil never designates the object sprinkled but the blood applied and 3) To read this verb as "to sprinkle" heightens a cultic reading of the text that never actually surfaces to the foreground. ${ }^{98}$ The basis of Childs's reading centers on more recent diachronic studies of blood atonement theology in ancient Israel. ${ }^{99}$ Childs, working within the framework of Gese's essay on atonement, does not think cultic, sacrificial imagery was available to the writer of Isaiah 40-55 and to read this cultic aspect of a later priestly tradition back into Isaiah would be anachronistic. One senses Childs's commitment to certain historical-critical, diachronic issues as an important part of his reading here.

What Childs does not seem to give due attention to is the "new Moses" imagery at work within the larger "new Exodus" paradigm taking place in Isaiah 4055. This identification of the Servant against the backdrop of Moses is not new within OT scholarship. ${ }^{100}$ But it does offer keen insights into one's understanding of the function and role of this Servant who seems to combine kingly, prophetic, and priestly functions, similar to that of Moses. Hugenberger has employed this "new Moses" imagery to help in his understanding of the term Mr. Moses is remembered as the one who sprinkled the altar with blood in the consecration of Aaron and his sons (Ex.

\footnotetext{
${ }^{97}$ Reventlow, "Basic Issues," 30.

${ }^{98}$ Childs, Isaiah, 412-413.

99 Particularly Hartmut Gese, "The Atonement" in Essays on Biblical Theology (Minneapolis: Augsburg Press, 1981), 93-116.

100 "'He ought not, of course, to be spoken of as a 'second Moses' or a Moses redivivus, but a prophet 'like Moses'." See Gerhard von Rad, Old Testament Theology, Vol. II, 261; Ronald E. Clements, "Isaiah 53 and the Restoration of Israel" in Jesus and the Suffering Servant, 47-50; Seitz, "Isaiah 4066," 461-462; Hugenberger, "The Servant of the Lord." Baltzer's commentary actually identifies the servant as Moses (Baltzer, Deutero-Isaiah, 21-22, 393; see also Karl Theodor Kleinknecht, Der
} 
29:16, 20; Lev 8:19, 24). Moses also "sprinkled" the entire people in Ex 24:18. ${ }^{101}$

Though Childs is correct to note that blood is sprinkled and not people, surely the conceptual category of the Servant's priestly role is not lost in this semantic

disjunction. Though the thrust of Isaiah 52:13-53:12 does not hinge on the weight one gives to its cultic imagery, the echoes to the Moses tradition should allow the reader to catch the cultic overtones.

Seitz leans away from reading "זֶ " as "sprinkle" based on what he perceives to be the wisdom context of these verses, although Seitz does not state his case as matter-of-factly as Childs. Rather, Seitz makes the following judicious comment worthy of quotation in full:

To say that the text is concerned with ritual cleanness or with juridical absolution or with the language of cultic sacrifice or with prophetic intercession (with models available in Moses, Jeremiah, Ezekiel, and others) or even with coloration from royal and priestly spheres-all these things may, indeed, be partly true. However, the death of the servant, and particularly the comprehensiveness of what is being claimed that it accomplishes, at this moment in the history of Israel and the nations expresses God's decision to deal with sin and estrangement at their most global expression. Israel sees this. The nations, when they see it, will be astounded and will shut their mouths. We must take seriously the text's own claim that it is telling us an unbelievable report, something not heard or comprehended. ${ }^{102}$

For as recalled from 49:1-6, the Servant is given a unique, dual role - that of restorer of the remnant of Israel and as light to the nations. This individual Servant, who embodies the vocation of faithful Israel, is revealed as the one who now fulfills this dual role in the fourth servant song. Therefore the Servant's suffering and death are Israel's on behalf of the nations, and the Servant's on behalf of the servants. ${ }^{103}$ This dual role is tightly knit to the overarching flow of the redemptive drama which moves towards it climax in this song and is highlighted in the opening verses of the poem, 52:13-15.

leidende Gerechtfertigte, Die alttestamentlich-jüdische Tradition von 'leidenden Gerechten' und ihre Rezeption bei Paulus, [WUNT 2; Tübingen: JCB Mohr, 1984], 47).

${ }_{101}^{101}$ Hugenberger, "The Servant of the Lord," 134-134.

${ }^{102}$ Seitz, "Isaiah 40-66," 464.

${ }^{103}$ Seitz, "Isaiah 40-66," 462. 
After Yahweh has made his statement regarding the Servant's humiliation and exaltation, the poem moves toward a new voice in $53: 1-9 .{ }^{104}$ The questions surface regarding the identification of the personal pronouns in this passage. ${ }^{105}$ Who are the "we" of 53:1? In Childs's reading the "we" are the faithful remnant of Israel who have been introduced in 52:15b. For Seitz, the servants of the Servant, or the offspring of the Servant promised in 53:10, speak about a historical act that has taken place. These servants of the Servant retrospectively observe and herald the significance of the work of the Servant who was despised and rejected. Contextually, these servants of the Servant are linked with the heralds of 52:7 who announce the coming reign of God. What these servants of the Servant emphasize in the dramatic narrative is the reversal of ideologies, that is, the coming reign of God is linked with that of the suffering one. In other words, the breaking in of God's "new thing" anticipated throughout Isaiah 40-55 arrives on the back of an individual who embodies Israel's vocation as light to the nations by suffering, dying, and vicariously bearing the sins of others in his own innocence. This, in short, is God's radical reversal of fortunes; God's methodology for redemption. It is with little wonder that the message is hard to believe (53:1).

The picture portrayed in 53:2-3, reminiscent of the suffering Psalms and Jeremiah, is that of repulsion and rejection. The ("surely') of 53:4 is in some sense a clarifying term. The reason behind the Servant's repulsive appearance and suffering (note the heightened poetic language) is his bearing of their "infirmities and sorrows" (53:4). The irony in 53:4 is that those for whom the Servant vicariously suffered deemed him smitten by God, not as one who was suffering in their stead. ${ }^{106}$ In 53:10, however, it is learned that their assumption, though not completely understood, was correct. It was God's plan of redemption to crush him. The Servant

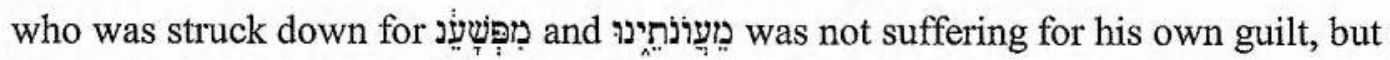
suffering innocently for the "transgressions" and "sins" of others (53:6), and this was the "will of God." "What occurred was not some unfortunate tragedy of human history but actually formed the center of the divine plan for the redemption of his

\footnotetext{
${ }^{104}$ Childs, in line with Beuken, actually argues that this new group is introduced in 52:15b. This new group, different from the nations, is a group within Israel who have received the revelation of the "new things" and confess this revelation in 53:1-9 (Childs, Isaiah, 413).

${ }^{105}$ See D.J.A. Clines, $\mathrm{I}, \mathrm{He}, \mathrm{We}$, and They-A Literary Approach to Isaiah 53 (JSOTSS 1; Sheffield: Sheffield Academic Press, 1976). Clines does not think the poem allows for a particular identification of the dramatic roles in this poem opting for a more open-ended interpretation.

${ }^{106}$ See n. 105.
} 
people and indeed the world." ${ }^{107}$ What needs to be remembered in this scene unfolding before the reader is not the post facto searching for significance of one who died "needlessly" or "innocently." What is taking place is the revelation of God's methodology for redeeming his people and the world by means of the suffering one, and the servants of the Servant bear witness to this reality as heralds of this message. $^{108}$

It is a good reminder from OT scholars such as Beuken and Childs that the Christian should be careful about uncritically reading various "atonement theologies" back into this text. Obviously, the prophet here is not necessarily a proto-Anselmian or whatever. On the other hand, the interpreter of Isaiah, listening closely to its own canonical voice, should be suspect of readings such as the following from Whybray: "The Servant cannot be said to be suffering, or to have suffered, in place of the exiles in such a way that they escape the consequences of their sins... The Servant...[as] one of them, shares their suffering....[H]e has suffered more intensely than they, and the 'we' who speak here confess that, at any rate compared with themselves, he is innocent; nevertheless this is shared and not vicarious suffering." ${ }^{\prime 109}$ What Whybrayand Morna Hooker for that matter ${ }^{110}$ - has identified in the work of the suffering Servant is that of suffering in solidarity, not "place-taking" or "vicarious suffering." The suffering Servant, in solidarity with the rest of the exiles, suffers alongside the guilty in his own innocence. ${ }^{11}$ Yet, this reading does not do justice to the final form of the canonical witness. Repeatedly the text says that the Servant's suffering and death was a vicarious suffering for the sins of others $(53: 4,56,8,10,11,12) .{ }^{112}$ Our

\footnotetext{
${ }^{107}$ Childs, Isaiah, 415 .

${ }^{108}$ Krašovic opines that the novelty of the "new thing" of God's redemptive activity in Isaiah 40-55 (66) is forgiveness (Krašovec, Reward, Punishment, and Forgiveness, 493).

${ }^{109}$ R. N. Whybray, Thanksgiving for a Liberated Prophet: An Interpretation of Isaiah 53 (JSOTSS 4; Sheffield: Sheffield Press, 1978), 30. See the extended discussion of this quotation in Daniel P. Bailey, "Concepts of Stellvertretung in the Interpretation of Isaiah 53" in Jesus and the Suffering Servant, 224.

${ }^{110}$ Morna D. Hooker, "Did the Use of Isaiah 53 to Interpret His Mission Begin with Jesus," in Jesus and the Suffering Servant, 88-103.

${ }^{111}$ Childs' interacts with Orlinsky, Whybray, and Hanson finding their particular readings a flattening out of the canonical witness (Childs, Isaiah, 415-416).

${ }^{112}$ An illuminating insight into the discussion of the nature of the vicarious sin-bearing of the servant is found in Daniel P. Bailey's, "The Concept of Stellvertretung in the Interpretation of Isaiah 53" in Jesus and the Suffering Servant. Bailey (239-240) rehearses the distinctions between Janowski and Hofius. Hofius, working under Kant's rubric - "sondern die allerpersönlichste, nämlich die Sündenschuld, die nur der Strafbare, nicht der Unschuldige, er mag auch noch so grossmütig sein, sie für jenen übernehmen zu wollen, tragen kann"-states, "Whether it deals with the prophet himself, or collectively with faithful Israel, or with a future messianic figure, in any case we must conclude: being freed up from sin and guilt through human substitution is theologically unthinkable." The problem, according to Hofius, with Isaiah 53 is that it is "not (incarnational) Christology" (Bailey, "The Concept of Stellvertretung, 240). Christ's place-taking (Stellvertretung) is of the inclusive kind. Christ's
} 
understanding of Isaiah 53 will obviously not give us a full-orbed theology of the atonement in a scholastic sense of the term, however, our understanding of the nature of this atonement as textually mediated within Isaiah 53's own canonical shape or plain sense will lead the reader to an understanding of an innocent sufferer bearing the sins of others in their place. Arguments based on the novum aspect of such a move within the "Hebrew Scripture" as support for its unintelligibility seem to miss the "new" and radical nature of God's redemptive, eschatological program within Isaiah. For as Isaiah 53:1 reminds the ancient and modern reader, the message of redemption by which the nations will be startled is difficult to believe.

The reader is reminded in 53:10 of the Lord's will in crushing and making the Servant suffer. God's method of redemption was programmed, if you will, around the work of this suffering one. Debates rage, however, on the exact meaning of the term 谞 in this same verse. ${ }^{113}$ Childs, leaning on the work of Janowski and Gese, ${ }^{114}$

entering into humanity does not "displace" us but "incorporates" us. "Both Christ and the rest of humanity are still 'there' when Christ takes or enters humanity's place" (Bailey, "The Concept of Stellvertretung," 241). Though Christ stepped into our place, this does not necessitate substitution in the exclusive sense. "Christ died in their stead (=place),' but not necessarily instead of them: they died, too, 'with' him" (Bailey, "The Concept of Stellvertretung," 241). Hofius argues, therefore, that Jesus Christ is not primarily explained by Isaiah 53, but Isaiah 53 is explained by him" (Bailey, "The Concept of Stellvertretung," 245). Janowski, on the other hand, quotes the same Kant passage but is not driven its claims. Janowski believes the Bible "formulates the problem differently" (Bailey, "The Concept of Stellvertretung," 246). Bailey points out that the contribution of Janowski centers on the epistemological aspects of stellvertretung, namely, how did Israel come to recognize their sins as being dealt with. Within Isaiah 53 the significance of the act of the Servant is only seen after the fact. "For Janowski, then, the drama of Stellvertretung lies precisely in that it is not reducible to a single abstract pattern of either representation or substitution. At the same time when the crucial events are happening, the sufferings undergone by the Servant seem neither representative nor substitutionary, for they appear to have nothing to do with anyone else. But after God makes it clear that the one has taken the place of the many, there are elements that might be regarded as both representative and substitutionary. The sufferings are substitutionary because something is done for the 'we' that they could not do for themselves..., and representative because what the Servant suffered represented their fate and not his" (Bailey, "The Concept of Stellvertretung," 248). Janowski makes the connection between this the subsequent looking back in Isaiah 53 to the subsequent response of the disciples and Paul to Jesus' death and its significance (Bailey, "The Concept of Stellvertretung," 249-250). Hofius' reading of Isaiah 53 as a "new text" in light of incarnational Christology raises a plethora of questions pertaining to the relationship of the testaments and their both pointing to the Triune God in their own distinct ways (see Brevard Childs, Biblical Theology). Perhaps the "new text" is the "old text." Also, Hofius' understanding of incarnational Christology raises certain questions pertaining to the necessity of the humanity of Christ in his soteriological work on the cross. With this said, however, the vicarious nature of the work of the servant-whomever he may be - is both substitutionary and representative, so Janowski. The Servant, as with Christ, represents his people by taking something on himself that was not his but theirs, and he also substitutes in their stead as his life is received as the means by which God forgives and pardons sins.

${ }^{113}$ The LXX is not helpful on this score, either. For $\pi \in \rho \grave{\alpha} \alpha \mu \alpha \rho \tau i \alpha \varsigma$ can also refer to "sin-offering." Cf. Lev 16:3 LXX. See N. T. Wright, The Climax of the Covenant: Christ and the Law in Pauline Theology (Minneapolis: Fortress Press, 1993), 220-225.

${ }^{114}$ Janowski, "Er Trug...;" Hartmut Gese, "The Atonement" in Essays on Biblical Theology (Minneapolis: Augsburg Press, 1981.), 93-116; Von Rad, Old Testament Theology, Vol II, 257. These 
denies the presence of any particular cult language in this verse, that is, the Servant's life is not a "guilt offering" in any cultic sense. For the actual term from "a secular situation in which compensation for a misdeed was demanded" (cf. I Sam. 6:3-4, 8, 17). ${ }^{115}$ Childs concludes that "the servant did not ritually obliterate $\sin$... There is nothing automatic or intrinsic in the servant's act that would result in forgiveness." 116 Childs wants to emphasize that the "point of the Isaianic text is that God himself took the initiative in accepting the servant's life as the means of Israel's forgiveness." 117

Ronald Clements, on the other hand, affirms the cultic language of Isa 53:10 on the basis of his understanding of the servant as a "new Moses." ${ }^{118}$ Clements understands of Isaiah 53 will be made holy. "Without the temple there could be no sin-offering to guarantee the continuance of a holy relationship to Yahweh. The ravages of guilt and disease, understood as the threats and misfortunes from which divine holiness brought deliverance, could not longer be held at bay. Yet now Deutero-Isaiah introduces his boldest of assertions, that God will accept the sufferings of the Servant-Israel, perhaps largely focused on the specific sufferings of the unnamed prophet himself, as the 'aŝam by which the restored nation will be purified.",119

all argue that Priestly strands are later than Deutero-Isaiah and therefore could not have influenced him. On the other hand, Markus Barth, though not unaware of the Priestly strand and its particular dating, states that "sacrificial vocabulary cannot be overlooked." Barth also stresses that "it is important to note how closely the sacrificial terminology and imagery is linked with the judicial element." Barth warns against the dangers of interpreting the actual "specific sacrifice" too closely and notes the absence of the words "blood" and "atone" in Isa 53. "But we believe that Levitical Laws, Holiness Code and Isa. 53 interpret each other mutually, and that Isa. 53 is not primarily an alternative or antithesis to true priestly and cultic mediation, but rather its presupposition. The cheap contrast between ethical prophetic and ceremonialist priestly teachings and writings is ripe for a final revision, or better, for burial without honour." Markus Barth, Was Christ's Death a Sacrifice?, Scottish Journal of Theology Occasional Papers, No. 9. (Edinburgh: Oliver and Boyd, 1961), 9 n.1. The point toward which Barth is driving is as follows: "This may possibly mean that even the Servant cannot be understood apart from the sacrificial background and consequence of his life and work" (9-10).

115 Childs, Isaiah, 418.

${ }^{116}$ Childs, Isaiah, 418.

117 Childs, Isaiah, 418.

${ }^{118}$ Clements, "Isaiah 53 and the Restoration of Israel," 50-51. Baltzer affirms the cultic language as well; however, it should be remembered that for Baltzer the servant is not a "new Moses" but the original Moses (Baltzer, Deutero-Isaiah, 421-422). Though not working from a Mosaic perspective, Smart concurs with the cultic/sacrificial imagery denoted in 53:10 (Smart, History and Theology in Second Isaiah, 212). Also, Eichrodt affirms the cultic language and imagery (Walter Eichrodt, Theology of the Old Testament, Vol. Two [London: SCM, 1967], 452). See also Rikki E. Watts, Isaiah's New Exodus in Mark (Grand Rapids: Baker, 1997), 276-277.

${ }^{119}$ Clements, "Isaiah 53," 51. 
This is, without doubt, a difficult question to adjudicate. One angle in the conversation is given by Seitz who urges against reading an entire cultic system into

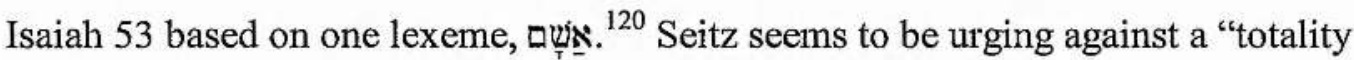
transfer" of sorts in this verse, aside from the problem of dating Israel's cultic theology. ${ }^{121}$ It seems beyond the limits of the text itself, historical reconstructions of Israel's cultic theology set aside, to deny some type of sacrificial imagery in Isaiah 53. For as one reads the contexts of Gen 26:10 and 1 Sam 6:3-4,8,17-where ș is ised in a legal sense-the situation will be found to be quite different than that of Isaiah 53. For in Isaiah 53 the Servant's suffering and death is meant to deal first and foremost with the removal and forgiveness of sins (Isa 53:4-6, 8, 10-12). ${ }^{122}$ We would agree with Childs that the point of the text is not strictly that of any inherent property of the Servant's suffering that forces God to forgive, but that the scene is one of God's gracious initiative towards his people. Yet, it fails to be persuasive that God's divine initiative does not take into account the righteous suffering of his Servant as the means of God's forgiveness, a sin-offering. Nowhere is God presented as the offended deity needing to be assuaged-Anselm-however, the gracious God doing his new work of redemption has in a radical fashion allowed the vicarious suffering of the Servant to be the basis for his forgiveness of the sins of the people. ${ }^{123}$ Therefore, we would concur with the danger of a totality transfer of the complete Levitical concepts of "guilt-offerings" to this passage; however, we would also warn against

\footnotetext{
${ }^{120}$ Seitz, "Isaiah 40-66," 467. Milgrom's work Cult and Conscience is a detailed analysis of a Levitical setting. He postulates a deep connection between $\sin$ /punishment and guilt feelings as the result of one's trespass against God - either by a "sancta trespass" or "oath violation"- with which the 口שָ wis was meant to deal (Cult and Conscience: The Asham and the Priestly Doctrine of Repentance, [SJLA 18; Leiden: Brill, 1976], 8, 16-17). Milgrom places concludes the following: "It is not the deliberate sinner who is excluded from sacrificial expiation but the unrepentant sinner...Thus remorse plus confession constitute the Priestly doctrine of repentance. Without sacrifice, however, it does not suffice to obliterate sin, as does prophetic repentance" (124). It is also interesting to note that Milgrom argues that the Priestly writings "were composed before the exile" (127).

${ }_{121}^{121}$ Again, Milgrom, Cult and Conscience, 127.

${ }^{122}$ For all the difficulties related to the LXX of Isaiah 53, the emphasis on the Servant's bearing and removal of sin is stark with the constant repetition of the term $\dot{\alpha} \mu \alpha \rho \tau i \dot{\alpha} \alpha$. See Moisés Silva and Karen Jobes, Invitation to the Septuagint (Grand Rapids: Baker Book House, 2000), 215-227.

${ }^{123}$ Seitz is helpful in the following statement: "A sharp separation between the judicial and the cultic realms, on the other hand, can also push things too far in an effort to rule out the latter. The text is sui generis as well as indebted to a previous religious history" (Seitz, "Isaiah 40-66," 467). See Watts, Isaiah's New Exodus, 275 n. 209; Barth, Was Christ's Death a Sacrifice? N.T. Wright states, "The word asam, translated in the LXX with peri hamartias, the regular phrase for 'sin-offering', may originally have had a wider range of meaning; by the first century we are safe in assuming that the
} 
the dangers of not observing the cultic imagery of the Servant's death as in some sense a sacrifice for sins.

Within 53:10-12 a grand reversal takes place as the Servant is promised

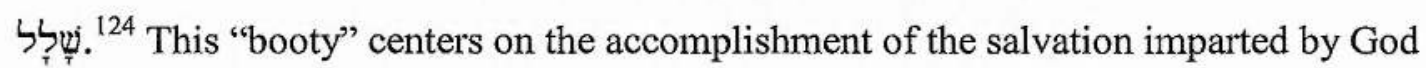
to the "many" by means of the work of the Servant. The Servant has stood in the place of transgressors and interceded for them in a way which surpasses that of both Moses and Jeremiah. ${ }^{125}$ The "many" referred to in 53:10-12 is linked to the many of the nations in 52:15 and the "we" group in the central part of the poem. ${ }^{126}$ This once astonished and appalled group has now been made righteous by the work of the Servant, and the Servant is promised offspring in 53:10 - a major theme to be developed in the rest of the book. The suffering, vicarious work of the Servant is the message of Yahweh, the wounded husband of 54:6-10, who is wooing back his people by means of his radical new act of redemption. The question is raised again, "Who then is this Servant?"

\section{3.a.iii The Servant's Narrative Identity}

Our purpose thus far has been to elucidate the broader narrative picture presented in the midst of the complexities of Isaiah 40-55. What has been observed is the call of God upon Israel to fulfill her vocational duty as a "light to the nations." Thus any attempt to dissect the work of the Servant from the work of Israel is wrongheaded from the start. On the other hand, any simple attempt at identifying the Servant as corporate Israel fails to take into account the development within the narrative flow. For Israel, though called to a specific task, is bound with the nations in their rebellion and is unable to fulfill her task (Isa 42:18-19). Therefore, a cryptic figure comes onto the scene in 49:3-6 who embodies the role of faithful Israel and is given a mission to both Israel and to the nations ("is it too small a thing" Isa 49:6). The twist in events comes in the drama when the Servant is rejected and ultimately killed by those to whom he came to announce salvation. What becomes apparent, from a post facto observation by the servants of the Servant, is that the suffering of this righteous one was God's means of redemption and forgiveness of sins. This, in short, is a take on

Levitical, i.e., sacrificial, meaning would have been the first, and probably the only, meaning to be "heard'" (N.T. Wright, Jesus and the Victory of God [Minneapolis: Fortress Press, 1996], 605 n. 227).

${ }^{124} \mathrm{LXX} \sigma \kappa \mathrm{U} \lambda \alpha$.

${ }^{125}$ Seitz, "Isaiah 40-66," 468.

${ }^{126}$ Reventlow, "Basic Issues," 29; Childs, Isaiah, 419-420. 
the larger narrative picture of Isa 40-55, and it stands at the heart of the canonical form of the text.

Questions still remain, however, regarding the actual identity of the Servant. Is the Servant the prophet? Is the Servant a figure from the Babylonian exile? Is the Servant an ideal figure? Getting at this question is a difficult task as one examines the textual material. For as Westermann reminds us, "The cryptic, veiled language used is deliberate. This is true of every one of the servant songs alike. From the very outset there must be no idea that exegesis can clear up their problems. The veiled manner of speaking is intentional, and to our knowledge much in them was meant to remain hidden even from their original hearers." ${ }^{\text {"127 }}$ What Westermann points at is the intentionality of the veiled language within the "servant songs."

A more nuanced reading of the identity of the Servant is given by Seitz who argues that the "obscurity" of the language is not due to any particular "device." "The reason we cannot identify the servant in these poems is that he has taken on the mantle of the prophets who have gone before in a long chain of prophets." ${ }^{128}$ Seitz opines that the Servant described is an actual historical figure, more precisely, the prophetic voice at work in these chapters $(40-55) .{ }^{129}$ The Servant's identity is veiled because his particular identity is in a sense swallowed up by the "culmination of prophetic Israel, whose testimony he takes up and whose suffering he willingly embraces." 130 We can concur with Seitz regarding the culmination of the prophetic

${ }^{127}$ Westermann, Isaiah 40-66, 93.
${ }^{128}$ Seitz, "How is the Prophet Isaiah," 190.
${ }^{129}$ Seitz, "How is the Prophet Isaiah," 190.
${ }^{130}$ Seitz, "How is the Prophet Isaiah," 190 ; Wilcox and Paton-Williams identify the Servant as the prophet ("The Servant Songs," 99). Childs (Isaiah, 414), commenting on Isa 53:2-3 states, "The figure who is portrayed appears in every way to have been a historical personage." However, the language begins to transcend a simple historical reconstruction. D. J. A. Clines has moved to a more readeroriented view of Isaiah 53. He concurs with Westermann's view of the intentionality of the veiled language. Clines argues that the enigmas of the poem were intended to "create another world, a world indeed that is recognizably our own, with brutality and suffering and God and a coming-to-see on the part of some, but not a world that simply once existed and is gone for good. The poem's very lack of specificity refuses to let it be tied down to one spot on the globe, or frozen at one point in history: it opens up the possibility that the poem can become true in a variety of circumstances - that is its work" (D. J. A. Clines, "Language as Event," in This Place is Too Small For Us: The Israelite Prophets in Recent Scholarship [ed. R. Gordon; Winona Lake: Eisenbrauns, 1995], 172). Though raising questions pertaining to the logic of prophecy, Clines' proposal is interesting and takes into account the poetic implications of the fourth servant song. However, the fluidity of its application may press the passage beyond its own abilities. Gerhard von Rad opines against the servant as historical figure position. Von Rad believes the biographical frame, especially that of the fourth servant song, cannot hold the picture of a historical personage. "The picture of the Servant of Jahweh, of his mission to Israel and to the world, and of his expiatory suffering, is prophecy of the future, and, like all the rest of Deutero-Isaiah's prophecy, belongs to the realm of pure miracle which Jahweh reserved from himself. It is, of course, probably that Deutero-Isaiah included a number of his own experiences during his prophetic ministry in 
tradition residing on this figure of the Servant. However, to argue too closely for the Servant's identity as that of a prophet behind the book seems to go beyond the witness itself. In short, the witness is silent regarding historical referent.

The questions will remain. However, one way of pressing toward an understanding of the identity of the Servant is to observe his narrative identity, that is, how the Servant is presented in his actions within the flow of the narrative. The question centers more on the "what" than the "who." Von Rad gives a helpful summary of the Servant's narrative identity when he states the following: he cleanses, he bears sickness, carries sorrows, chastisement is laid upon him, his stripes heal, he makes his life a substitute, he makes righteous, he pours out his life, he acts vicariously. ${ }^{131}$ The role of the Servant is that of "light to the nations" and this role is accomplished in his suffering.

Coupled with these actions are the observations already given by Bauckham that the Servant is in some way-for Bauckham "is"-caught up into the identity of God himself on the basis of the intertextual link between Isa 6:1 and Isa 52:13. Similarly, Isaiah 52:13 LXX chooses the term "glorification" for the "exalted" of the MT. Elsewhere in Isaiah the prophetic word has emphasized twice over that YHWH's glory belongs to none other than Himself (Isa 42:8; 48:11). "I will give my glory to no other." Yet in Isaiah 52:13, the Servant is narratively depicted as one who is sharing in what belongs to YHWH alone, his glory. ${ }^{132}$ It could be said like this: the narrative description of God's unique acts and attributes in the book of Isaiah are now being attributed to the Servant in such a way that the identity of the two bleed onto one another. The narrative identity of the Servant and of Yahweh act in a perichoretic relationship.

What is striking is that one finds the Servant's narrative identity in a sense developing from that of active agent $(42: 1-4 ; 49: 1-6)$ to more of a passive agent $(50: 4-$ $6 ; 52: 13-53: 12){ }^{133}$ The Servant is identified as one who trusts God in the midst of the suffering and is characterized by his obedience to the divine summons even when the summons leads him to humiliations, suffering and ultimate "defeat." The Servant's mission is God's mission; the Servant is God's means of redeeming his people and

his picture of the Servant. That is not to say that he and the Servant were one and the same person" (Von Rad, Old Testament Theology, Vol. II, 260).

${ }^{131}$ Von Rad, Old Testament Theology, Vol. II, 257.

${ }^{132}$ Larry Hurtado, Lord Jesus Christ: Devotion to Jesus in Earliest Christianity (Grand Rapids: Eerdmans, 2003), 384-389. 
drawing in the nations. In the narrative identity of the Servant, one catches a glimpse of a figure whose entire being and reason for existence is to carry out obediently the will of God's redemptive purposes. The language used to describe the Servant's obedient and passive actions are extraordinary when thought of being tied to a human personage. ${ }^{134}$ However, as Isaiah reminds us, this is the astonishingly new, redemptive act of God. In the end, Barth may have a final word for our reading of the Servant, "The question whether this partner, the servant of the Lord, is meant as collective Israel or as a single person - and if so, which? a historical? or an eschatological? - can never be settled, because probably it does not have to be answered either the one way or the other. This figure may well be both an individual and also the people, and both of them in a historical and also an eschatological form. What is certain is that in and with this servant of the Lord Israel as such is at any rate introduced also as the partner of Yahweh." "135 In other words, God was in the Servant reconciling the world unto himself and this divine agent, the Servant, is unique in his identity as described narratively in the text.

The presentation of the Servant in Isaiah 40-55's canonical voice has been attended to in this section. It is believed that this understanding of the Servant as embodiment of true Israel and agent of reconciliation between God and humanity forms much of Paul's christological thought in 2 Cor 5:14-21. Also, the nontransferable identity of the Servant as embodying the very actions and character traits of Yahweh is an important element of Paul's theological thought. Our attention, therefore, turns specifically to Paul.

\section{The Servant Jesus in 2 Corinthians 5:14-21}

A virtual web of complexities arises as the interpreter enters this rich yet debated portion of Pauline literature (similar to that of Isaiah 53). The topics of choice

\footnotetext{
${ }^{133}$ Clines, "Language as Event," 174.

${ }^{134}$ Robert Jenson has given keen theological insight into Isaiah 49 from a Trinitarian perspective. "So much at least is clear: whatever may have been in the mind or minds of the author or authors of this text...followers of the risen Jesus were only conforming to the actual statement of the text when they took it as applicable to their Lord. For the text presents an historically unfilled template, indeed a template unfulfillable by anyone who lives only within the parameters of this age, of history as it now proceeds. To fit that template to someone is to say that this particular Israelite brings Israel back to the Lord and that just so this person is Israel thus brought back, to take her final mission to the nations" (Robert Jenson, "The Bible and the Trinity," in Pro Ecclesia vol. XI, no. 3 [2002]: 334-335).

${ }^{135}$ Karl Barth, Church Dogmatics: Vol. IV.1 (Edinburgh: T\&T Clark, 1956), 29.
} 
typically center on Paul's use of $\kappa \alpha \tau \alpha \lambda \lambda \alpha \sigma \sigma \sigma \omega,{ }^{136}$ the nature of the new creation (anthropological or cosmological), ${ }^{137}$ and that most elusive of verses, 5:21. ${ }^{138}$ What has been argued thus far is that Paul invites the reader into the redemptive, dramatic world of Isaiah 40-66 by means of his sum-up statement of the message of that drama in 2 Cor 6:2- "Now is the day of salvation." For Paul, the redemptive drama of Isaiah 40-66 was forward looking with a set pattern of God's means of redemption for both Israel and the nations of the world. ${ }^{139}$ The central feature of that pattern in both Isaiah 40-55 (66) and 2 Cor 5:14-21 is the reconciling work of God (divine initiative) by means of an innocent sufferer (Servant/Jesus) resulting in the forgiveness of sins. Though the arguments become dense and complex when one starts to flesh this oute.g. representation or substitution, sin-offering or apotropaic ritual, etc.-the overall thrust of the narrative witness becomes apparent as the redemptive drama of Isaiah 40-55 (66) and the heralded message of Paul in 2 Cor 5:14-21 come together in a combustive manner. ${ }^{140}$

Hofius and Beale have given the most detailed attention to the overlap of the Isaianic drama and 2 Cor 5:14-21. Hofius, as has been observed in the preceding chapter, bases his opinion of the Isaianic background for this text (and the concept of "reconciliation") on his observation of overlapping patterns found in Isaiah 53 and 2 Cor 5:14-21. The results of Hofius's query rest on his emphasis of die Sache of the texts over against a strict reading of die Begriffe ${ }^{141}$ Methodologically, Beale is hand in hand with Hofius. Commenting on the background of Paul's "reconciliation"

\footnotetext{
${ }^{136}$ See Cilliers Breyentach, Versöhnung. Eine Studie zur Paulinischen Soteriologie (WANT 60; NeukirchenVluyn: Neukirchener, 1989); I. Howard Marshall, "The Meaning of 'Reconciliation'," in Unity and Diversity in New Testament Theology: Essays in Honor of George E. Ladd (ed. R. A.

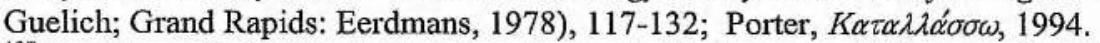

${ }^{137}$ See Moyer V. Hubbard, New Creation in Paul's Letters and Thoughts (SNTS 119; Cambridge: CUP, 2002); Ulrich Mell, Neue Schöpfung: Eine traditionsgeschictliche und exegetische Studie zu einem soteriologischen Grundsatz paulinischer Theologie (BZNW 56; Berlin and New York: Walter de Gruyter, 1989).

${ }^{138}$ Jean-Noel Aletti, "God made Christ to be Sin (2 Corinthians 5: 21): Reflections on a Pauline Paradox" Unpublished paper presented at Redemption Summit 2003; R.H. Bell, "Sacrifice and Christology in Paul," in JTS 53 (2002), 1-27; Otfried Hofius, "Sühne und Versöhnung" in Paulusstudien, 33-49 (esp. 46-48); B. Hudson McClean, The Cursed Christ: Mediterranean Expulsion Rites and Pauline Soteriology (JSNTS 126; Sheffield: Sheffield Academic Press, 1996), 108-113; N.T. Wright, "On Becoming the Righteousness of God: 2 Corinthians 5:21," in Pauline Theology Vol II: 1 and 2 Corinthians (ed. D. Hay; Minneapolis: Fortress Press, 1993), 200 - 208.

${ }^{139}$ See Craig A. Evans, "Paul and the Hermeneutic of 'True Prophecy'," in Bib 65 (1984), 560-570.

140 "It is precisely here - reading the Old in light of the New and the New in light of the Old - that combustion takes place and fresh theological hearing, in a modern context under the influence of the Holy Spirit, occurs" (Seitz, Word Without End, 105).

${ }^{141}$ Hofius, "Erwägungen," 11.
} 
language, Beale laments the "too narrow view of establishing parallels on a semantic basis, often to the exclusion of conceptual considerations." 142

Beale's analysis of 2 Cor 5:17-21 begins with the Isaianic allusion in 2 Cor

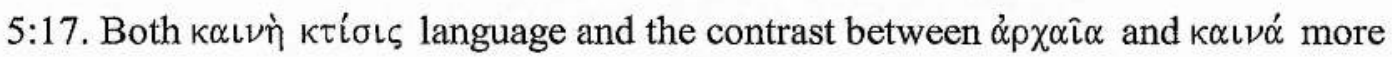
than hint at Isaianic passages such as Isa 43:18-19 and Isa 65:17. ${ }^{143}$ Beale correctly states that commentators have for the most part noted the Isaianic allusion in 2 Cor 5:17, yet have failed to even make an attempt to "link this Old Testament background closely with the following discussion of reconciliation in verses 5:18-21."144 Beale's following statement is a keen insight into the possible cause of this oversight: "We can only suppose that there has been no discussion of the recognized links with Isaiah because commentators perhaps view Paul as merely using Isaiah's words to convey his own new thought which is foreign to the Old Testament context." ${ }^{145}$ Beale takes the rest of his article to show that "although this is a possible view, it is improbable." 146

For Beale, the new creation, as received by Paul, is the fulfillment of exilic promises made to Israel concerning the establishment of a peaceful relationship with Yahweh. ${ }^{147}$ Beale is right to note that return from Babylonian exile is a major theme of Isaiah 43 (esp. 14-15) and that Israel's "sin or iniquity is the cause of Israel's forsaken condition." 148 God uses the Servant to deal with the people's sin and bring them back into a peaceful relationship with himself, the restoration of Israel from exile. From this argument, Beale paints the picture of Paul's usage in 2 Cor 5:17-21 of "new creation" and "reconciliation" language as an adaptation of this theme from Isaiah. For Paul, the "new creation" is the removal of the separation between God and sinful humanity by the death and resurrection of Christ thus inaugurating the true Israel, the church, into the presence of God. ${ }^{149}$ The OT conceptual background as portrayed in Isaiah, tipped off by Paul's "new creation" imagery, is the source for Paul's thinking on reconciliation. Beale concludes this section in the following way: "Simply put, Paul understands both 'new creation' in Christ as well as 'reconciliation' in Christ (2 Cor. 5:18-20) as the fulfillment of Isaiah's promise of a new creation in

\footnotetext{
${ }^{142}$ Beale, "Old Testament Background," 218.

${ }^{143}$ See also Hays, Echoes of Scripture, 159, 223 n. 15.

${ }^{144}$ Beale, "Old Testament Background," 221.

145 Beale, "Old Testament Background," 221.

${ }^{146}$ Beale, "Old Testament Background," 221.

${ }^{147}$ Beale, "Old Testament Background," 225.

${ }^{148}$ Beale, "Old Testament Background," 223.
} 
which Israel would be restored into a peaceful relationship with Yahweh. And Israel's exile in Isaiah is seen as representative of humanity's alienation from God, since Paul is applying Isaiah's message for Israel to Gentiles."150

The preceding summary of statement of Beale raises certain questions. First of all, though Paul does use "new creation" language in 5:17, the "new thing" about to be accomplished by Yahweh in Isaiah 40-55 (66) centers on the dramatic development of the Servant figure within the narrative. Beale does not avoid discussion of the Servant (he even gives a nod in the direction Hofius has taken in arguing the centrality of the Servant in this passage), ${ }^{151}$ yet the action of the Servant is not the driving concern of Beale's argument. Rather, the "new creation" and the "return from exile" for Israel is the key concern. Why this move in light of Beale's seeking to understand the OT in its own voice when the "return from exile" is not as resounding a theme as the universal work of the Servant in bringing salvation to the ends of the earth (Isa 49:6)? Secondly, Beale presents a picture in this article of Isaiah as concerned about the restoration of Israel and of Paul as adumbrater of this picture to that of sinful humanity. This would be, in the estimation of this author, a collapsing of the sensus literalis with the sensus historicus. For in fact, Isaiah's canonical voice pressures an understanding of the central role of the Servant on behalf of the nations (Isa 52:13-15). Without doubt, the import of the exile in Isaiah should not be missed; however, to filter all theological readings through this lens would cause the reader to miss the larger purpose of Isaiah's own plain sense voice. For in Isa 2:1-5 all the way through to the picture of the "new creation" in Isaiah $65 / 66$ the nations play a key role. ${ }^{152}$ It should be remembered, as has been mentioned, that the Servant's vocational mission as explicated in Isa 49:6 was to bring salvation to the ends of the earth. To present Paul as concerned with humanity and Isaiah as concerned with the return from exile, is a false disjunction in the canonical form of Isaiah 40-55 (66). Also, to view Isaiah as Scripture, or the viva vox Dei, would push Isaiah's own message beyond its original, historical context into an eschatological context pointing beyond itself to something greater.

\footnotetext{
${ }^{149}$ Beale, "Old Testament Background," 225.

${ }^{150}$ Beale, "Old Testament Background," 225.

${ }_{151}$ Beale, "Old Testament Background," 226.

${ }^{152}$ See n. 41; W.A.M Beuken, "Isaiah Chapters LXV-LXVI: Trito-Isaiah and the Closure of the Book of Isaiah" in Tradition and Re-Interpretation in Jewish and Early Christian Literature: Essays in Honor of Jurgen C.H. Lebram (ed. J.W. van Henton; Leiden: Brill, 1986), 204-221.
} 
Hofius's method of observing the overlapping patterns between Isaiah and 2 Cor 5:14-21 will be a template for our own approach to this passage. What is of import to note is that the central concerns of Isaiah 40-55 (66) are the highlighted aspects of Paul's thought in 2 Cor 5:14-21. Thus, it can be inferred that Isaiah's own drama of redemption has imposed a considerable amount of coercion on Paul's understanding of the significance of God's work in Christ. The key areas of overlap are as follows: 1) the death of the one for the all;2) the inauguration of the new era or new creation as founded upon the work of the Servant/Jesus; 3) the divine initiative of God toward reconciling humanity with himself; 4) Christ/Servant as the agent of reconciliation; and 5) the forgiveness of sins as the central motif of reconciliation.

\section{4.a The One for the All}

Paul is defending the validity of his apostolic ministry in the larger discourse where 5:14-21 is found. Paul downplays the parading of ecstatic experiences in 5:13 as he elucidates for the Corinthians the true heart of an apostle, specifically, self-denial for the sake of the Gospel and others. Surely Paul has had "ecstatic experiences" yet these are for God, not for public display. For Paul, what is necessary is his "being in his right mind" for the sake of those to whom he ministers and for the sake of the Gospel. ${ }^{153}$ Therefore, Paul begins 5:14 with an explanation of the controlling factor in his life, i.e., the love of Christ. ${ }^{154}$ Paul continues by fleshing out what this "love of

\footnotetext{
${ }^{153}$ Paul's downplaying of ecstatic experiences in this context may add further reluctance to reading his ecstatic, conversion experience as the background for this text. See Thrall, II Corinthians, 406; Martin, 2 Corinthians, 127; Furnish, II Corinthians, 324. Hubbards challenge of the consensus view-Paul is defending his un-rhetorical speech thus giving the Corinthians an opportunity to boast of the Spirit-is helpful in light of 5:12, yet in the end in unpersuasive on the basis of Paul's datives in 5:13 ( $\theta \in \hat{\omega} / \dot{i} \mu \mathrm{i} \nu)$. For if Paul is using '́ $\xi^{\prime}$ 'oт $\mu \iota$ in the way Aristotle used it in his handbook Rhetoric (an interesting connection between $\pi \epsilon i \theta \omega$ and $\epsilon \xi i \sigma \tau \eta \mu \iota$ together-- "In cautioning against a style of speech which is too metrical and rhythmic in its delivery, Aristotle warns his students that this would not only fail to

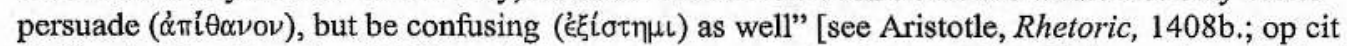
Hubbard, New Creation, 166]) one fails to see the connection between "confusing and unpolished rhetoric" for God and "reasonable and lucid" rhetoric for the Corinthians (Hubbard, New Creation, 167). In what way is "confusing, unpolished speech" in any way for God? In concurrence with Hubbard, the passage is difficult, namely, in what way does Paul give the Corinthians criterion for boasting (5:12)? Yet, the rhetorical angle does not do justice to the contrasts Paul is seeking to display in 5:13, that is, the contrast "for God...for you." Quite possibly, Paul's giving to the Corinthians an opportunity to boast will be found later in the context in which Paul displays his suffering as proof of his authentic apostleship. This proof is not necessarily attractive but is validated in light of God's program of redemption.

${ }_{154}$ Defining ouv'́ $\chi \in \mathrm{L}$ is a tricky task. If one leans on the context of 5:11-13 the force of the verb may be negative in nature. "The love of Christ 'controls' or 'restrains' us." Thus Paul is showing that the love of Christ keeps him from a flaunting spirit. This is the position of Thrall, II Corinthians, 408-409. On the other hand, if one takes into account the verse that follow, a more active sense of the verb may be opted for. Martin states, "The idea behind $\sigma u \nu \in \hat{\xi} \xi \in t \nu$ is deeper than a 'moral influence' of the love of
} 
Christ" looks like. Christ's love is not a love that seeks self-fulfillment or selfadvancement but is a love that gives itself completely for the other. Christ's love is a

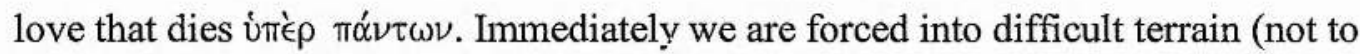
mention theological debate). The question put simply is, "Did Christ die 'instead of' or 'on behalf of' mankind?" The answer to this question is laden with multiple preunderstandings and pre-commitments in the mind of the interpreter. In light of Isaiah $40-55$, however, it is of import to note that this complex question is the same question posed to the work of the Servant. Did the Servant die in an exclusive or inclusive way for his people? ${ }^{155}$ Is the language of representation better than that of substitution? ${ }^{156}$ The point being, the overlap between the ambiguity of our understanding of the work of the Servant and the work of Christ is readily apparent.

It is important to read 5:14-15 in light of the immediate context of reconciliation and 5:21. For in 5:21 Paul also uses the preposition ùmép. In addition, the message of reconciliation is intricately linked to the "not taking into account their transgressions" (5:19), the preamble to 5:21. Reading these texts in light of each other (5:14-21) also offers a more acute sense of Isaiah 40-55 (more specifically the work of the Servant) in the background. One notes an emphasis in 5:14-21 that is highlighted in Isaiah 53. The Servant and Jesus die on behalf of others in spite of their own innocence. The emphasis in Isaiah 53 is the Servant's action of taking sins and offences that were not his own (Isa 53:5, 6, 8, 10,11). Though the Servant is not presented as "sinless," the conceptual overlap of the Servant taking sin that was not

Christ, acting so as to restrain one's behavior in terms of boasting. In 5:14, Paul is not looking back to $5: 11-13 \ldots$ as much as he is looking forward to his theme of reconciliation. The love of Christ compels...us to be included in Christ and his mission. The point is that 'compels' signifies a positive force" (Martin, 2 Corinthians, 128). Adjudicating between these two positions is difficult and semantically the options could go either way (see Thrall, $I$ Corinthians, $408 \mathrm{n} .1513$ ). Contextually, Paul is making the case that the love of Christ keeps him from seeking his own as he "lives for the one who died and was raised." Thrall doubts whether Paul meant both senses at once (Thrall, $I I$ Corinthians, 408). I am not so sure. For Paul does emphasize the restraint of self-aggrandizement coupled with the compelling nature of his living for the one who died and was raised. Quite possibly, Paul did have the nuanced effect of both meanings at once. Regarding the genitive toû Xpเoroû the subjective genitive is the best reading, i.e. Christ's love (Martin, 2 Corinthians, 128).

${ }^{155}$ The nuanced debate between Janowski and Hofius on inclusive and exclusive Stellvertretung comes to mind (see n. 112).

${ }^{156}$ See James D.G. Dunn, "Paul's Understanding of the Death of Jesus" in Reconciliation and Hope (ed. R. K. Banks; Exeter: Paternoster Press, 1974). Dunn's reading is influenced by his assurance of "Adam Christology" coming into play for Paul in "the one died for all, therefore all died" (Dunn, The Theology of Paul the Apostle, 210). John R. Levison has argued against Dunn's reading of Adam theology in the Second Temple Period, though Levison does not necessarily disagree with Dunn's conclusions (John R. Levison, Portraits of Adam in Early Judaism: From Sirach to 2 Baruch [JSPS1; Sheffield: Sheffield Academic Press, 1988], 20-21). 
his own and Jesus in sinlessness taking on himself sins that were not his own is manifestly present.

A tradition-historical reading of Isaiah 53 and Paul would emphasize the lack of any parallel within Judaism of a suffering messiah dying in the place of others. Hengel states, "So far, then, we have no clear text from pre-Christian Judaism which speaks of the vicarious suffering of the Messiah in connection with Isa. 53. Of course this does not rule out the possibility of such a tradition, and there are some indications in favour of it, but the basis provided by our sources is too restricted. At all events, a suffering Messiah did not belong to the widespread popular Messianic hope in the time of Jesus and a crucified Messiah was a real blasphemy." ${ }^{157}$ With that said, to lean too heavily on a tradition-historical reading of Paul and Isaiah 53 would not take into account the new situation of Paul's particular OT reading. Paul reminds the reader "now is the day of salvation." The event of God's redemption of his people and humanity is an actualized event in the person and work of Jesus Christ. For Paul, an innovative reading of the redemptive drama of Isaiah $40-55$ as fulfilled in Christ is a reading that takes into account God's eschatological work in the person and work of Christ. Hengel concludes, "On the other hand, we must ask whether too much weight is not being attached to the tradition-historical argument, since we reckon with creative innovations in the earliest Christian community, which was utterly influenced by an enthusiastic and eschatological experience of the Spirit. These revolutionary innovations already began, after all, with Jesus." 158

Also, Otto Betz's reading of 2 Cor 5:16 comes into play. For Betz, this particular verse cannot be understood apart from Isaiah 53. To regard Christ according to the flesh would entail not taking into account Christ's suffering as guiltless and on the behalf of others. "Rather 'he died for all' (2 Cor. 5:15), for our sake God 'made him to be sin who knew no sin' [see Isa. 53:9b], so that in him 'we might become the righteousness of God' (2 Cor. 5:21)."159 Betz expresses the change in mind that takes place in Isa 53:1ff of those who now recognize in retrospect the significance of the work of the one who suffered and died in innocence. This "new epistemology" is the epistemology of the new age by which God has manifested his

\footnotetext{
${ }^{157}$ Martin Hengel, The Atonement (London: SCM Press, 1981), 57.

${ }^{158}$ Hengel, The Atonement, 57. See also Dietrich-Alex Koch, Die Schrift als Zeuge des Evangeliums (BHT 69; Tübingen: J.C.B. Mohr [Paul Siebeck], 1986), 234.
} 
program of redemption as laid out in Isaiah 40-55, an innocent sufferer taking the place of those God seeks to redeem. ${ }^{160}$ This knowledge becomes apparent only after the fact and has significant impetus for those who find themselves with this new epistemology. Though this particular theme will be explored more fully in the next chapter, the impetus given in this new epistemology is that God furthers his redemptive program by righteous sufferers (2 Cor 6:3-10). As the servants of the Servant in Isaiah 53-66 continue the work of the Servant in righteous suffering compelled by the work of the Servant who died on their behalf - a post facto realization, a new epistemology-so also does Paul say that his new epistemology presses him on in his activity as a servant of Christ.

Within the debates over the exact nature of Christ's work - substitution or representation - one is reminded that the starting point of our particular passage is the work of God through Christ as a work mankind could not have completed left to him or herself. Martin seeks a mediating position-leaning on the work of Romaniukthat emphasizes both the representative and substitutive aspects of Christ's work. ${ }^{161}$ Whether or not one finds Martin's position tenable, it is of import to recognize on a grass roots level that Jesus did something for humanity in his death and resurrection that humanity could not do for itself. Therefore, Christ's death was in his stead. On the flip side of the same coin, Christ is not merely an intermediary figure standing between humanity and an offended deity, but is actually taking man up into himself as humanity's representative. Thus, all die and are raised in him to serve the one who died on their behalf. An organic connection is noted between the one who dies for the other and the ones for whom the figure dies. It should be added that this connection is noted in Isaiah 53 as well.

\footnotetext{
159 Otto Betz, "Jesus and Isaiah 53" in Jesus and the Suffering Servant, 77. See also Otto Betz, "Fleischliche und geistliche Christuserkenntnis nach 2. Korinther 5,16" in Jesus, der Herr der Kirche, [WUNT 52; Tübingen: JCB Mohr, 1990], 114-128.

${ }^{160}$ Though J. L. Martyn does not use Isaiah 53 in his argument, the connections of his thought with the

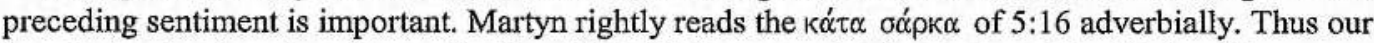
knowledge has been transformed in the midst of this new eschatological age. For Martyn "the new way of knowing is not in some ethereal sense a spiritual way of knowing. It is not effected in a mystical trance, as the pseudo-apostles claimed, but rather right in the midst of the rough-and-tumble life...On the contrary, it is life in the midst of the new-creation community, in which to know by the power of the cross is precisely to know and to serve the neighbor who is in need" (J. L. Martyn, "Epistemology at the Turn of the Ages" in Theological Issues in the Letters of Paul [Edinburgh: T\&T Clark, 1997], 109).

${ }^{161}$ Martin, 2 Corinthians, 130-131. Thrall challenges Martin's reading of Romanuik (II Corinthians,
} 410). 
One cannot help but observe the silence regarding the actual nature of how God does what he does through Christ for man. The questions of "How could God do...?" are numerous in the interpretation of both Isaiah 53 and 2 Cor 5:14-21. Aletti has emphasized the paradoxical and silent nature of Paul's statement in 5:21. This silence emphasizes the mysterious ways of God. This is seen also in the passage of the Servant. The Servant's ways are a part of the mysterious ways of God's dealing with his people's sin and rebellion. In 5:21 Christ is observed taking something from humanity and for humanity that humankind could not do on its own, and in 5:14-15 Christ's death is our death and resurrection. Thus to place the category of the atonement in distinct categories of substitution versus representation misses the multifaceted and complex realities connected to the atonement. For in Christ, God has reconciled the world unto himself by both identifying with humankind and working on behalf of humanity. ${ }^{162}$

\section{4.b The New Eschatological Age}

"If anyone is in Christ, New Creation!" (2 Cor 5:17). As has been observed, the Isaianic message of redemption rings quite loudly in this verse. Beale is correct to observe the connections of "new creation" and "old and new" language with Isaiah. Again, one wonders whether or not Paul had a specific proof-text in mind (e.g., Isa 43:18-19 or Isa 65:17) or whether Paul was working with larger conceptual categories as having been fulfilled in Christ. The language of "old things passing" and "new

\footnotetext{
${ }^{162}$ Jean-Noel Aletti has written an insightful article on 2 Cor 5:21, "God made Christ to be Sin". Aletti emphasizes the paradoxical and mysterious manner of 2 Cor 5:21. "Paul does not say why and how the fact that Christ was identified with Sin made all sinners become God's righteousness: the connection between the becoming Sin of Christ and our becoming righteousness of God is neither unfolded or explained" (Aletti, "2 Cor 5:21," 13.) Aletti emphasizes the amazing statement of 5:21, that is, Christ became a sinner-Aletti denies reading $\dot{\alpha} \mu \alpha \rho \tau i ́ a$ as "sin offering"-and we actually became righteous-the genitive tov̂ $\theta \in o v$ is a subjective genitive for Aletti. A christocentric view of this reality is stressed by the prepositional phrase ' $\mathrm{C} \nu$ $\alpha \dot{\tau} \tau \omega$ at the end of $5: 21$. Thus, "all that we are and have, is christologically coloured" (Aletti, "2 Cor 5:21," 14.) Aletti concludes with rhetorical flourish on this paradox of Paul, "How can the one who dispossessed himself of everything enrich others and the one who became a curse be a blessing? Paul does not give a response! Why does he not tone down his paradoxes? Most likely because he wants to stress that God's ways cannot be mentally digested and that Christ's death cannot be announced except through the rhetoric of exaggeration...Paul's paradoxes espouse and describe God's mysterious will and ways" (Aletti, "2 Cor 5:21,"15.). The connection of the mysterious will and ways of God as espoused in 2 Cor 5:21 and Isaiah 53 combust with one another as the servants of the Servant emphasize the incredulous nature of their message "Who has believed our message?" (Isa 53:1) and as Paul announces the "new epistemology" that recognizes the Christ as having died for others as he ushers in the new eschatological age (2 Cor 5:16). See also Ernst
} 
things taking place" is scattered throughout Isaiah 40-55. Retreating back to our study of the larger dramatic narrative of Isaiah 40-55 (66), it is recalled that the "new thing" of God's redemptive plan centers narratively on the work of the Servant.

Martin suggests that the emphasis of the verse is not necessarily on the one who enters (anthropologically centered, e.g., "new birth" texts like John 3:3,5,7) but on the age being entered (eschatologically centered). ${ }^{163}$ "To conclude: '́ $\mathcal{\nu}$ X $\rho\llcorner\sigma \tau \hat{\text { "⿻ }}$

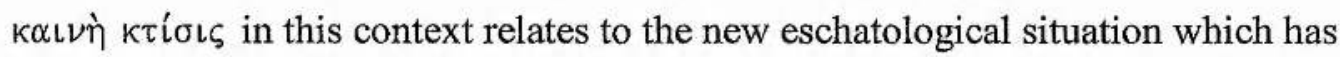
emerged from Christ's advent." "164 Paul's exclamation of "new creation' in 5:17 is another way of saying "Behold, now is the acceptable time of God's favor, behold, now is the day of salvation" (6:2) and is exclamatory in nature.

Hubbard's recent attempt to read "new creation" through an anthropological lens has raised profitable questions. For Hubbard, the options for the reading of "new creation" are either cosmological or anthropological in focus. ${ }^{165}$ Is the new creation a new cosmological order or is it the new situation of the individual? Difficulty arises, however, in the categories with which Hubbard works. For surely if one downplays the soteriological aspects of 5:17-21—e.g. reading кó $\mu \circ \varsigma$ in 5:18 as shorthand for the cosmic order per se instead of the world of humanity - the thrust of the redemptive context would be lost. ${ }^{166}$ Hubbard has justifiably challenged the tradition-historical reading of "new creation," yet it seems as if he has not given proper weight to the eschatological significance of "new creation." Paul explains the "new creation" in terms of the old having passed and the new having come. For Hubbard, based on his reading of Isaiah, this is soteriological in nature. ${ }^{167}$ With affirmation Hubbard's

Käsemann, "The Saving Significance of the Death of Jesus in Paul" in Perspectives on Paul, 39. Käsemann observes the false disjunction between Jesus' death "for our advantage" and "in our stead." ${ }^{163}$ Moyer Hubbard has recently attempted to debunk the cosmological reading of "new creation" opting for a more anthropocentric center. "Paul's new creation expresses a reality intra nos not a reality extra nos, and functions as an alternative formulation of his central Spirit affirmation - the Spirit creates life" (Hubbard, New Creation, 232).

${ }^{164}$ Martin, 2 Corinthians, 152. G.K. Beale has recently argued for "new creation" as the center for a biblical theology of the NT. "My thesis is that the major theological ideas of the New Testament flow out of the concept that Christ's life, and especially death and resurrection through the Spirit, launched the end-time new creation for God's glory." G.K. Beale, "The Eschatological Concept of New Testament Theology" in 'The Reader Must Understand': Eschatology in Bible and Theology (ed. K. E. Brower and M. W. Elliott; Leicester: IVP, 1997), 11-52. See also Mell, Neue Schöpfung; Hubbard, New Creation. Richard Hays has programmatically used "new creation" as a hermeneutical "focal image" in The Moral Vision of the New Testament: A Contemporary Introduction to New Testament Ethics (San Francisco: HarperCollins, 1996); see also his Echoes of Scripture, 159; see also Bernhard Anderson, From Creation to New Creation (Minneapolis: Fortress Press, 1994).

165 See especially his interaction with Furnish. Hubbard, New Creation, 180-181.

${ }^{166}$ Furnish, II Corinthians, 181.

${ }^{167}$ Hubbard, New Creation, 182. 
soteriological concerns are received, though not at the expense of emphasizing that for Paul the turn of the ages has taken place. ${ }^{168}$ The long awaited time of God's intervention on behalf of man - that eschatological/soteriological event-has taken place in Christ. ${ }^{169}$ Placing a strong dichotomy between apocalyptic/eschatological categories and the redemption of humanity should be avoided. ${ }^{170}$ For Paul, these two aspects are conjoined. Paul's use of the redemptive drama of Isaiah and its vision of a new ordering of affairs in which God acts on behalf of his people in the figure of a suffering one is playing a dominant role. This new act of God in Christ is the long awaited day of salvation. ${ }^{171}$ Ridderbos is judiciously accurate on this score, "When he speaks here of 'new creation,' this is not meant merely in an individual sense (a 'new creature'), but one is to think of the new world of re-creation that God has made to dawn in Christ, and in which everyone who is in Christ is included."172 The overlap of Paul's affirmations and Isaiah's vision are important to hold together in the reading of the new creation. Conjoined with the eschatological/soteriological aspect of God's work in Christ is the initiatory step of God toward the world of humanity in reconciliation.

\section{4.c The Divine Initiative in the Act of Reconciliation and the Servant/Christ as Agent}

It is recalled that within the larger narrative of Isaiah 40-55 the action of God on behalf of his people is laid bare as the action of the Servant. It is also recalled in Isa 52:10 that the Lord's announcing of his coming salvation will be for and in the sight of all nations. This coming salvation will take place in the "laying bare of his holy arm." Contextually in 52:13-15, all the nations do see the "arm of the Lord" laid bare before them in the person and work of the suffering Servant. Thus, the actions of Yahweh are intricately connected to the actions of the Servant. God's action on behalf

\footnotetext{
${ }^{168}$ See David Wenham, Paul: Follower of Jesus or Founder of Christianity (Grand Rapids: Eerdmans, 1995), 52-54.

${ }^{169}$ See B.W. Longenecker's discussion of "new creation" in Galatians (The Triumph of Abraham 's God: The Transformation of Identity in Galatians [Nashville: Abingdon Press, 1998], 37). Also, it seems Pauline to place soteriology as a sub-category under the rubric of eschatology. On the emphasis on the historia salutis over the order salutis see Herman Ridderbos, When the Time Had Fully Come: Studies in New Testament Theology (Grand Rapids: Eerdmans, 1957), Paul: an Outline of His Theology (Grand Rapids: Eerdmans, 1997); The Shorter Writings of Geerhardus Vos: Redemptive History and Biblical Interpretation (ed. R. Gaffin; Philadelphia: Presbyterian and Reformed, 1980). ${ }^{170}$ See B. W. Longenecker on the danger of placing too strong a wedge between "apocalyptic" and "covenantal" categories ("Defining the Faithful Character of the Covenant Community" in Paul and the Mosaic Law [ed. J.D.G. Dunn; Grand Rapids: Eerdmans, 2001], 76-77).

${ }^{171}$ See Hays, Echoes of Scripture, 159.

${ }^{172}$ Ridderbos, Paul, 45.
} 
of his people and the world takes place on the basis of God's gracious and free initiative toward his people - the comfort of Yahweh in Isaiah 40 is not based on the cry of the people but on God's own determined and gracious initiative. This divine initiative, however, does not take the form expected-triumph and the like-but takes the form of a suffering one who embodies the vocation of a people steeped in their rebellion. It was a post facto event that allowed the servant followers of the Servant to recognize the enormous reality having taken place in the person and actions of this lone, suffering figure. Only after the fact did they realize that God's holy arm of salvation was displayed in the paradoxical fashion of a suffering figure who died in their stead and on their behalf.

One catches a glimpse of this same reality in 2 Cor 5:18-19 where the divine initiative of God on behalf of mankind-his reconciling the world to himself - takes form in the person of Christ. ${ }^{173}$ The work of God and the actions of Christ are thus inseparably linked. God's gracious and free initiative toward the world of mankind takes form in the action of the Christ. Interestingly enough, the activity of Christ in 5:18-21 takes a more passive form as God acts through him. ${ }^{174}$ The narrative identity of Christ as he moves toward his passion becomes more of a passive identity than an active one. Vestiges of Barth's motif "the judge who was judged" comes to mind. ${ }^{175}$ What is of import, for our purposes, is to note the overlap of patterns between the Servant of Isaiah 40-55 and the Christ of 2 Cor 5:14-21. Both the Servant and the

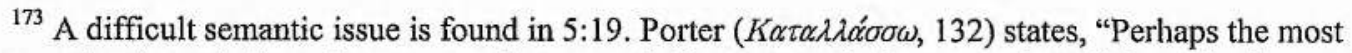
complex issue in the entire passage, however, is the grammatical construction of the main clause of $\mathrm{v}$. 19: ทิ่ 'ย $\nu$ X periphrastic - option 1, "God was reconciling to himself the world in Christ" or option 2, "God was reconciling the world to himself through Christ- or to take $\eta^{n} \nu$ as an independent copulative- "God

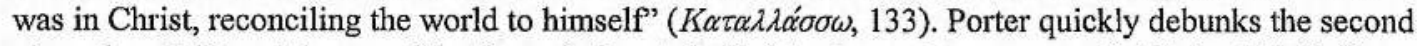
view, though Barrett is one of the few scholars to hold this view and more recently Richard $\mathrm{H}$. Bell, "Sacrifice and Christology in Paul" in JTS 53 (2002): 9-11. (Bell interacts with Porter's Verbal Aspect in the Greek of the New Testament with Reference to Tense and Mood [Studies in Biblical Greek I;

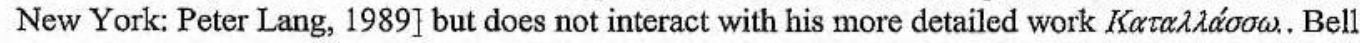
finds the independent clause "God was in Christ" to be more persuasive than the periphrastic reading.)

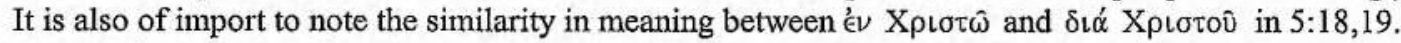
The emphasis is placed on the means by which God will reconcile the world. The periphrastic reading

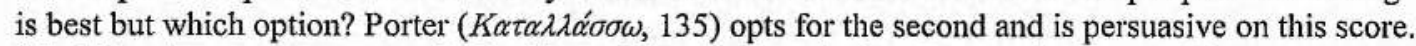
"God functions as the grammatical subject of the clause and, therefore, as the agent of the active voice participle, acting through or by Christ to effect reconciliation." See Aletti, "2 Cor 5:21," 6. Geerhardus Vos at the beginning of last century understood the construction in 5:19 as periphrastic. For Vos, the periphrastic construct emphasizes the centrality of God's resultant actions in Christ as actions initiated and fueled by God alone (Vos, "The Pauline Concept of Reconciliation" in Redemptive History and Biblical Interpretation, 362).

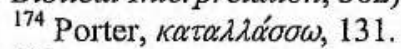

${ }^{175}$ Barth, $C D I V .1,224-228$.
} 
Christ are the agents through which Yahweh works on behalf of the redemption of his people. Coupled with this, the action of the Servant/Christ and the action of Yahweh are inseparably linked in an ontic connection. ${ }^{176}$ Any "pagan notion" of "reconciling an angry God" is absent within this text. It is not God who is reconciled but mankind. Both in the Isaianic drama and in 2 Cor 5:14-21 the picture of a gracious God advancing redemptively toward a sinful people is strikingly revealed. ${ }^{177}$ It follows, therefore, to pursue the actual character of reconciliation in its relationship to the forgiveness of sins.

\section{4.d Reconciliation and the Forgiveness of Sins}

The concept of reconciliation, no less the doctrine of reconciliation, has been a debated topic within the realm of New Testament studies/theology. ${ }^{178}$ Lexical studies have been employed as well in the search to unravel Paul's thought associated with

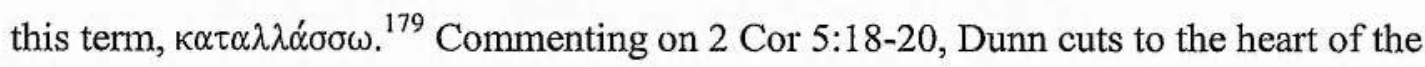
matter, "The imagery is obvious. It presupposes a state of estrangement or hostility

${ }^{176}$ See Jenson, "The Bible and the Trinity."
${ }^{177}$ See Bultmann, The Second Letter to the Corinthians, 159 and Theology of the New Testament, Vol.

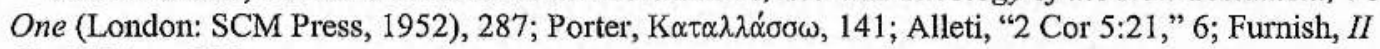
Corinthians, 335.

${ }^{178}$ One is reminded of Käsemann's article "Some Thoughts on the Theme 'Doctrine of Reconciliation'," in ET The Future of our Religious Past (ed. J. M. Robinson; New York: Harper and Row, 1971). Käsemann, for various ecclesiological and Christological reasons, denies the validity of placing the doctrine of salvation under the rubric of reconciliation. For an appreciative critique of Käsemann, see Childs, Biblical Theology, 484-485; also Ralph Martin, Reconciliation: A Study of Paul's Theology (London: Marshall, Morgan \& Scott, 1981), 71-79. Childs (Biblical Theology, 486), in line with Barth, helpfully states, "I would argue initially that the term reconciliation can also function as a broad, inclusive theological category and is not necessarily a rival as such to the doctrine of justification." See also Barth, CD, IV/1-3, Ridderbos, Paul, 182-204; Dunn, The Theology of Paul, 228230; Adolf Schlatter, The Theology of the Apostles, 245-248.

${ }^{179}$ Marshall's initial article traces the use of $\kappa \alpha \tau \alpha \lambda \lambda \alpha \dot{\sigma} \sigma \sigma \omega$ in Hellenistic writings-special emphasis is given to 2 Macc., p. 120-121 - and concludes that Paul uses the term in a unique sense. "Paul's use of the term was sufficiently creative to produce a concept which has come to the forefront in theological thinking. By his new use of the terminology he made it clear that reconciliation is a term for what God as subject has done in relation to the world as object. But whereas in popular usage 'to reconcile $\mathrm{Y}$ to oneself' means 'to remove Y's ground for being offended,' Paul uses the phrase to mean 'to remove Y's offense.' The offense in question is the sin of mankind which arouses the wrath of God and prevents him from entering into friendly relations with them; when the sin is removed or cancelled the reconciliation is achieved" (Marshall, "The Meaning of 'Reconciliation'," 130). Porter has expanded

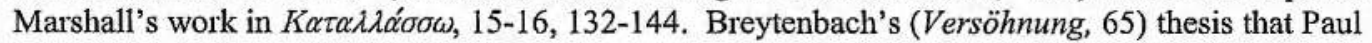
developed his concept of $\mathrm{K} \alpha \tau \alpha \lambda \lambda \alpha \dot{\alpha} \sigma \omega$ from the diplomatic vocabulary of the Hellenistic world and not the OT, or post-biblical Judaism, has been aptly challenged by Stuhlmacher in "Cilliers Breytenbachs Sicht von Sühne und Versöhnung," in JBTh 6 (1991): 339-354. Similarly, Barclay emphasizes Paul's non-Hellenistic definition of the people of God, opting for an OT background to this particular issue and others (John M. G. Barclay, Jews in the Mediterranean Diaspora: From Alexander to Trajan [323 $B C E-117$ CE] [Edinburgh: T\&T Clark, 1996], 388-389). Barclay's emphasis is that Paul was an anomalous Diaspora Jew. All in all, an OT background is to be preferred in understanding Paul's creative usage of this term. 
between God and humankind." ${ }^{180}$ Furnish also offers a succinct three-point summary of reconciliation in 5:18-21. 1) God was reconciling the world to himself. 2) Christ was the agent of reconciliation. 3) Reconciliation means not charging trespassers with their trespasses. ${ }^{181}$ Contextually, our understanding of reconciliation must be

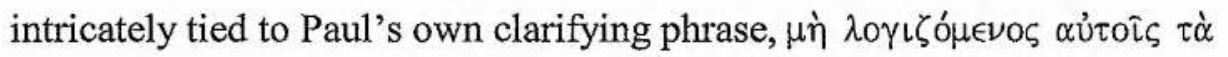
$\pi \alpha \rho \alpha \pi \tau \omega \dot{\omega} \mu \tau \alpha \alpha$ ư $\tau \hat{\omega} \nu$ (5:19). Whatever else may have been in the mind of Paul at the time, the reader is assured that Paul's thinking on reconciliation is linked with the fissure having come to the relationship between God and mankind on the basis of their sins/transgressions. ${ }^{182}$ God's aggressive removal of the offense between himself and mankind is God's aggressive removal of the barrier of sin.

It is precisely at this point where Isaiah's voice is at its zenith in pressuring a particular understanding of God's activity in Christ for the apostle. For in Isaiah the crucial aspect of the Servant's work was not in his bringing Israel back from exile per se but in his atoning work on behalf of a people steeped in sin and rebellion (Isa $42: 18-25 ; 43: 24 ; 53: 5,6,10,12$ ). The perpetual problem of Israel's sin and rebellion is the heart of the matter. Any notion of comparing "forgiveness of sins" to "return from exile"- - unless exile has come to mean nothing more than a spiritual metaphormisses the driving concern of both Isaiah and Paul, namely, the need for the removal and forgiveness of sins. ${ }^{183}$ God's concern is the renewal of the heart (Isaiah 58,59), and he activates this reality by his own sovereign initiative in the work of the Servant in Isaiah and of the Christ in Paul. In other words, Israel's deepest problem is mankind's deepest problem, i.e., sin and rebellion. On this score Israel and the nations join in solidarity, and God acts on behalf of Israel and the nations through his Servant to remove this ultimate obstacle. It cannot be emphasized enough that this obstacle in the canonical voice of Isaiah is not a physical locale-Babylon-but an internal reality-rebellious and sinful hearts. For as in Isa 49:6-God seeks to bring salvation to the ends of the earth by the work of the Servant-so in 2 Cor 5:19 - God brings salvation/reconciliation to the world through the agency of Christ. At the heart of Isaiah's and Paul's message of reconciliation stands the pertinent and perpetual

\footnotetext{
${ }^{180}$ Dunn, Theology of Paul, 229.

${ }^{181}$ Furnish, II Corinthians, 334.

${ }^{182}$ For a detailed analysis of $\sin$ in both the OT and NT see Stanislas Lynonnet, S.J. and Leupold Sabourin, S.J., Sin, Redemption, and Sacrifice: A Biblical and Patristic Study (Analectica Biblica 48; Rome: E Pontifico Instituto Biblico, 1970), 3-57.

${ }^{183}$ N.T. Wright has affirmed that "forgiveness of sins" is shorthand for "return from exile" (Jesus and the Victory of God, 268.
} 
problem of mankind's sinfulness. The only possibility of its removal is through the gracious and free initiative of God on mankind's behalf, e.g. the forgiveness of sins. $^{184}$

Questions still remain, however, as to the exact manner by which God has acted in Christ. From 5:18-19 it is surmised that God was reconciling the world unto himself by the agency of Christ - again the overlap between God's redemptive action for Israel and the nations by means of the Servant in Isaiah 53 is noted. Also, key to our concept of reconciliation is the problem of sin which has brought about the fissure between God and man. The complexities surface in our attempt to understand 2 Cor $5: 21{ }^{185}$ Contextually, Paul is continuing to deal with the concept of transgressions and sins (5:19), yet uncertainty is still present when one seeks to understand Paul's exact thought in 2 Cor 5:21. Does Paul's reference to $\alpha \mu \alpha \rho \tau i ́ \alpha \nu$ '́moín $\sigma \in \nu$ mean "sin offering," ${ }^{186}$ Christ's actually becoming a sinner, ${ }^{187}$ a forensic declaration ${ }^{188}$ or some other competing notion? ${ }^{189}$

Aletti helpfully emphasizes the paradoxical nature of 2 Cor 5:21 in his attempt at pointing out the silence of the actual "how" and "why" of 5:21. 190 "Paul's paradoxes espouse and describe God's mysterious will and ways." ${ }^{191}$ This is a heeded warning in our attempt at understanding the totality of Paul's thought in 5:21. Frankly, it is beyond our grasp to understand completely what Paul has in mind-

\footnotetext{
${ }^{184}$ Seitz insightfully analyzes Wright's particular account of Isaiah in "Reconciliation and the Plain Sense Witness of Scripture" unpublished paper, 2002.

${ }^{185}$ The most detailed account of the history of interpretation on 2 Cor $5: 21$ is found in Lynonnet and Sabourin, Sin, Redemption, and Sacrifice, 188-244. It is striking to note how many of the early Church Fathers read 2 Cor 5:21 in light of Isa 53-e.g., Origen (194); Cyril of Alexandria (196-197); Theodoret of Cyrus (202); St. Hilary of Poitiers (204). The most common reading of "made to be sin" in the early church is "sin-offering."

${ }^{186}$ See N.T. Wright, "On Becoming the Righteousness of God," in Pauline Theology: Vol. II

(Minneapolis: Fortress Press, 1993), 207-208; "The Meaning of ПEPI' AMAPTIA in Rom 8.3" in Climax of the Covenant, 220-225; see also, Dunn, Theology of Paul, 218-223; Charles H. Talbert, Reading Corinthians: A Literary and Theological Commentary on 1 and 2 Corinthians (New York: Crossroads, 1989), 167-168.

${ }^{187}$ Bell, "Sacrifice and Christology in Paul," 13-14.

${ }^{188}$ Ridderbos, Paul, 168.

${ }^{189}$ Of course, locating Isaiah 53 in the background of 5:21 is not a novel observation. See Martin, 2 Corinthians, 153; Hofius, Erwägungen. Furnish hedges away from the Servant idea because in the LXX the Servant is actually justified (II Corinthians, 339). This assumes that Paul only used the LXX (an allusive term) in his reading of the OT, a position Bauckham has, in my opinion, successfully challenged (God Crucified, 50); "James and the Jerusalem Church," 452-462; see Hengel, The PreChristian Paul, 35. See also the comparison made between Isa 53 and 2 Cor 5:21 in Lynonnet and Sabourin, Sin, Redemption, and Sacrifice, 253-255. This may be an instance, as well, that proves Paul's knowledge of and use of a Hebrew Vorlage (see David Sapp, "The LXX, 1QIsa, and the MT Versions of Isaiah 53 and the Christian Doctrine of Atonement," in Jesus and the Suffering Servant, 170-192).

${ }^{190}$ Aletti, "2 Cor 5:21," 13.

${ }^{191}$ Aletti, "2 Cor 5:21," 15.
} 
"sin-offering," etc. Aletti opines this is rhetorically purposeful. However, in light of the already abundant allusions to Isaiah in this passage $(5: 14,17 ; 6: 2)$ the theological reader is clued in to Isaiah's redemptive drama. On the theme of paradox, one notes the same level of paradox in Isaiah 53-the totality of the "how" and "why" is not answered as the reader is forced to stand back at the incredible and scandalous nature of God's work in the Servant, "Who has believed our message?" (Isa 53:1). To read 2 Cor 5:21 completely in terms of "sin-offering" is to miss the larger allusion to Isaiah's message and the unique character of God's work in the Servant and in the Christ. Thrall states,

Whilst Paul does refer to this death in sacrificial language, and whilst also the passage Isa 53.9-11 may be in his mind here, the $\dot{\alpha} \mu \alpha \rho \tau i \alpha$ is to be understood in terms more personal than that of a 'sin offering', which suggest the objective neutralising and removal of sins rather than a radical change which needs to be brought about in the personal relationship of the sinner with God. ${ }^{192}$

One may quickly ask, "Is not this same unique reality as described by Paul in 2 Cor 5:21 not also present in Isaiah 53?" Did not the "sin offering" of Isaiah 53 also take into account the "more personal" nature of God's act of forgiveness in the suffering and death of the Servant? Paul's categories may have been more fluid, as Isaiah's were. To draw a one-to-one parallel between every aspect of "sin offering" and the death of Christ would miss the larger conceptual overlap Paul is seeking to affirm. It should be noted, however, that this same fluidity is found in Isaiah's own portrayal of the connection, is what is emphasized-someone took the place of others in both an exclusive and inclusive manner because of and on account of their sin. For as in Isaiah 53, where the Servant is seen taking on sin in sinlessness (Isa 53:5-10) with the result of making many righteous (Isa 53:11), so too does the Christ take on sin in sinlessness resulting in mankind's receiving of God's righteousness (2 Cor 5:21). ${ }^{193}$ This

\footnotetext{
192 Thrall, II Corinthians, 442.

${ }^{193}$ See Wright, "On Becoming," for a different reading of "becoming the righteousness of God." God's righteousness is his "covenant faithfulness. (For a reading that opposes "righteousness of God" as "God's covenant faithfulness" see Mark A. Seifrid, "Righteousness Language in the Hebrew Scriptures and Early Judaism," in Justification and Variegated Nomism, 423-424.) In the end, though Wright offers keen insights, his portrayal does not do justice to the antithesis set out in 5:21- He became $\sin . .$. we became righteous (see Aletti, " 2 Cor 5:21," 13; Porter, K $\alpha \tau \alpha \lambda \lambda \dot{\alpha} \sigma \omega, 142-143$ ). With this said, it would be an oversight to not take into account the covenantal aspects of justification. Dunn helpfully

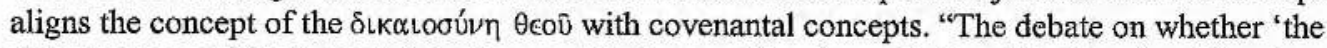
righteousness of God' was subjective or objective genitive, 'an activity of God' or 'a gift bestowed by God,' can too easily become another piece of either-or exegesis. For the dynamic of relationships
} 
particular reading takes into account both the chiastic nature of 2 Cor 5:21- he

became sin (in whatever way) and we became righteous - and the allusion to Isaiah 53 's suffering Servant. ${ }^{194}$ Reading the larger dramatic narrative of Isaiah 53 helps us

simply refuses to conform to such analysis...The other dispute, as already noted, was whether the verb dikaioō means 'make righteous' or 'reckon righteous.' But once again the basic idea assumed by Paul was of a relationship in which God acts on behalf of his human partner, first in calling Israel into and then in sustaining Israel in its covenant with him. So once again the answer is not one or the other but both. The covenant God counts the covenant partner as still in partnership, despite the latter's continued failure. But the covenant partner could hardly fail to be transformed by a living relationship with the life-giving God" (Dunn, Theology of Paul, 344). Childs also emphasizes the covenantal aspects of "righteousness" in the OT (Childs, Biblical Theology, 489). Childs (Biblical Theology, 490) concludes, "Righteousness in the Old Testament is not some ontological state of cosmic harmony, but an event inaugurated by God's intervention into the world for the sake of humanity, and rendered according to the divine will." Childs also concurs with Dunn on the objective and subjective aspects of

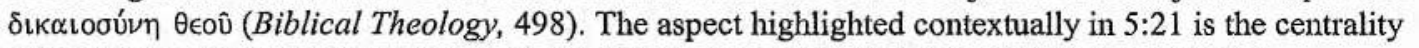
of God in the reconciliation of man. God took the gracious initiative toward man, and God's righteousness (both objectively and subjectively) is central to the making right of man before God in spite of mankind's sin. The controversies over justification-especially with regard to imputationwill, no doubt, continue to rage. One final word from Barth would seem appropriate at this point, "There is no room for any fears that in justification of man we are dealing only with a verbal action, with a kind of bracketed 'as if,' as though what is pronounced were not the whole truth about man. Certainly we have to do with a declaring righteous, but it is a declaration about man which is fulfilled and therefore effective in this event, which corresponds to actuality because it creates and therefore reveals the actuality. It is a declaring righteous which without any reserve can be called a making righteous" (Barth, $C D I V .1,95)$. In light of our particular passage of study, it is of interest to note that Barth connects justification with new creation (CD IV.1, 96); see N.T. Wright, What Saint Paul Really Said: Was Paul of Tarsus the Real Founder of Christianity (Grand Rapids: Eerdmans, 1997), 113-133; M. A. Seifrid, Justification by Faith: The Origin and Development of a Central Pauline Theme (NovTSup 68; Leiden: Brill, 1992); Justification and Variegated Nomism; E.P. Sander, Paul and Palestinian Judaism (London: SCM, 1977); Ridderbos, Paul, 159-181; E. Käsemann, "The Righteousness of God" in New Testament Questions of Today (Philadelphia: Fortress Press, 1967), 168-182; C.K. Barrett, "Paul and the Introspective Conscience," in The Bible, The Reformation and the Church: Essays in Honor of James Atkinson (JSNTS 105; Sheffield: Sheffield Academic Press, 1995), 36-48; Paul and the Mosaic Law.

${ }^{194}$ Das has recently affirmed the possibility of Isaiah 53 as background of 2 Cor 5:21, yet he hedges away from referring to $\alpha \mu \alpha \rho \tau i \alpha$ as "sin offering" because of his concern that the chiastic structure of the verse will be lost (A. Andrew Das, Paul, the Law, and the Covenant [Peabody: Hendrickson, 2001], 131-132). McLean's thesis of Paul's dependence on Mediterranean apotropaic rituals as opposed to OT sacrificial imagery is not persuasive. McLean affirms the fourth Suffering Servant Song as the "only text in the whole of the Hebrew Bible where suffering and death could be interpreted as having expiatory significance for others" (B. Hudson McLean, The Cursed Christ: Mediterranean Expulsion Rituals and Pauline Soteriology [JSNTS 126; Sheffield: Sheffield Academic Press, 1996], 49). McLean (The Cursed Christ, 49) does not find this helpful, however, for "the concept of atonement in this passage is so foreign to anything else in the Hebrew Bible"-Mclean quotes Hengel on this score yet fails to quote Hengel's approving notion of Paul's unique exegesis in light of the eschatological situation in which Paul finds himself, see above n. 143-144. McLean may have fallen prey to an overemphasis in his tradition-historical reading of Paul. Again, he (The Cursed Christ, 51) states, "Indeed, there is no text in the Jewish tradition which contains teaching that a righteous man can vicariously atone for the sin of others by becoming accursed and sinful." What of Isaiah 53? McLean finds it astounding that Paul only quotes from Isaiah 53 twice. "It is remarkable that in all of Paul's letters there does not exist a single clear allusion (let alone quotation) to any verse of Isa 52.13-53.12 having to do with suffering, humiliation or atonement" (The Cursed Christ, 50). This statement is rather dubious. Questions are initially raised as to what constitutes a "clear allusion?" Also, McLean does not take into account the role of metalepsis in Paul's thought (see Hays, "Who Has Believed our Message?"). McLean denies the presence of Isa 53.6 in 2 Cor 5:21 and uses Oscar Cullman as his validation. Dunn has rightly pointed out that McLean misquotes Cullman (Dunn, Theology of Paul, 217 n. 53). The larger redemptive drama of Isaiah 40-55, especially as climaxed in 53, gives the reader the 
to tread a path through the paradoxes of God's activity in Christ on behalf of humanity, a paradox that leaves mankind in mystery as to the exact nature of its happenings. What is of import, however, is to note the same paradoxical nature in both Isaiah and 2 Cor 5:14-21. ${ }^{195}$ God has acted through his agent by means of his suffering and death to remove the obstacle between God and humanity, namely, sin, resulting in their being made right before God, that is, our justification. ${ }^{196}$ The "sin offering" is illustrative of God's activity through both the Servant and Christ but does not do complete justice to the unique reality of God's new reconciling work. ${ }^{197}$

\section{Conclusion}

Paul's understanding of the action of God through the agency of Christ on behalf of mankind is in some sense mediated by God's redemptive portrayal in Isaiah 40-55. The overlap of patterns in both the suffering Servant and the Christ offer the biblical theological reader of the two-fold canon insight into the paradigmatic, providential, and paradoxical nature of God's reconciling work. God reconciles his people by the actions of a suffering one which in Isaiah is the Servant and in Paul is the Christ. Paul's reads Isaiah as witness to something beyond itself, that is, God's action in Jesus Christ. The text of Isaiah is read as a figural pointer to God's redemptive work by means of Jesus Christ. Paul models Christian reading of the OT where the text is both authoritative and understood most properly in light of its true subject matter, Jesus Christ.

\footnotetext{
keenest insight into Paul's redemptive thought in 2 Cor 5:21 (see also, Linda Belleville, "Gospel and Kerygma in 2 Corinthians," in Gospel in Paul: Studies on Corinthians, Galatians and Romans for Richard N. Longenecker, [JSNTS 108; ed. L. Ann Jervis and P. Richardson; Sheffield: Sheffield Academic Press, 1994], 147.

${ }^{195}$ See Seitz, "Isaiah 40-66," 467.

${ }^{196}$ See Schlatter, Theology of the Apostles, 247.

${ }^{197}$ See Childs's comments on the Servant and the NT (Isaiah, 420-423). With reference to Richard Hays' seven criteria of "echoes" this particular reading of the redemptive drama of Isaiah 40-55 as echoed by Paul in 2 Cor 5:14-21 seems to fit nicely. Those criteria being as follows: 1) availability; 2) volume; 3) recurrence or clustering; 4) thematic coherence; 5) historical plausibility; 6) history of interpretation; 7) satisfaction (Hays, "Who Has Believed Our Message?" 212-220). As beauty is in the eye of the beholder, so to may an intertextual echo be only in the eye of the beholder. However, with possible exception to criteria two (though I to think Isaiah 40-55 was a "popular text" for early Christians-Hays, "Who Has Believed Our Message?" 214), these categories are arguably met in reference to the larger message of Isaiah 40-55 in 2 Cor 5:14-21. As Hays states, "The point is that there is abundant evidence in Paul's letters that he read Isaiah 40-55 as a coherent prophetic vision foretelling and authorizing Paul's own apostolic activity" (Hays, "Who Has Believed Our Message? 217).
} 


\section{CHAPTER FOUR}

\section{PAUL: A SERVANT OF THE SERVANT}

\section{Introduction}

The previous chapter emphasized the significant role the Servant figure of Isaiah 4055 played for Paul in 2 Cor 5:14-21. Paul understands himself to be in the midst of the eschatological now, a period of divine history pointed to by Isaiah and brought to its fulfillment in the person and work of Jesus Christ, the embodiment of true and faithful Israel struck down by the Father for the reconciliation of the world, i.e. the Servant. ${ }^{1}$ It has been argued that 2 Cor 6:2 serves as a hermeneutical key for 2 Cor 5:14-6:10, that is, 2 Cor 6:2 marks Paul's reading of Isaiah as an eschatological reading while at the same time it invites the reader into the larger redemptive narrative of Isaiah 40-55 (66). Paul's purpose within the contextual flow of 2 Cor 2:14-7:2 is to defend his apostolic ministry by means of a self-commendation approved by the Lord. ${ }^{2}$ Thus, Paul's warrant for self-commendation in light of his suffering and weakness is found most explicitly in the Scriptures of Israel, and in this climactic section of Paul's selfapologetic, more specifically, Isaiah 40-55 (66).

In light of the typological significance of the Servant as related to the person and work of Christ in 2 Cor 5:14-21, it becomes less plausible that Paul considers himself to be the Servant addressed in Isaiah $49: 8 .^{3}$ A typological clashing of identification within such a close proximity-2 Cor 5:14-21 and 2 Cor 6:2 -renders this reading untenable. ${ }^{4}$ With this said, however, Beale and Webb's identification of Paul with the Servant is found untenable on the basis of an attenuation, not complete disagreement. For the conclusions of both Beale and Webb are linked with their close identification of the work of Paul with the work of the Servant. In other words, their sensibilities are pointed in the right direction. Yet, the typological significance of the

\footnotetext{
${ }^{1}$ An insightful and illuminating study on the theological theme of the death and resurrection of the "first-born" in the Old Testament is given by Jon D. Levenson, The Death and Resurrection of the Beloved Son: The Transformation of Child Sacrifice in Judaism and Christianity (New Haven: Yale University Press, 1993).

2 See Hafemann, "Self-Commendation."

${ }^{3}$ Again, this is the conclusion of Beale, "The Old Testament Significance," and Webb, Returning Home.

${ }^{4}$ This becomes more convincing if one accepts the argument of Bauckham in God Crucified, e.g., the Servant is identified with Yahweh.
} 
Servant is a weight too great to be placed on the shoulders of Paul. Someone greater than Paul is needed to carry this significance and it has been argued that this person is Jesus Christ. The question remains, "Where does Paul fit within the eschatological now, and does Isaiah 40-66 help in the clarifying of this typological clashing?"

\section{Paul's Suffering and 2 Cor 6:3-10}

2 Cor 6:3-10 contains a list of hardships the apostle has encountered (a

Peristasenkataloge). ${ }^{5}$ Within 2 Corinthians 1-9 two "hardship lists" occur, one in 4:89 and the other in 6:3-10. The interconnection of these two lists are of import, for

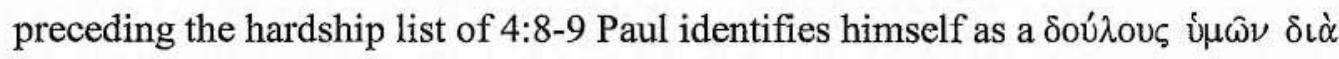

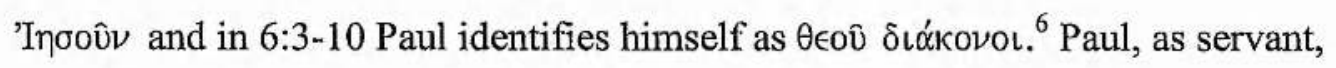
carries about in his own body the death of Jesus for the purpose of giving life to the Corinthians (2 Cor 4:10-12). ${ }^{7}$ The exact nature of Paul's "always carrying about the death of Jesus in the body" is a complex mixture of both metaphor and reality. ${ }^{8}$ For the effects of Paul's suffering are in a very real sense moving him toward death (4:8 $9,12,16)$, yet, as Schütz points out, "The point of contact between Christ's death and Paul's weakness is in Paul's suffering." ${ }^{.9}$ Paul affirms the subordinate role he takes.

\footnotetext{
${ }^{5}$ Peristasis in short means "circumstances" and is a neutral term that can refer to both good and bad circumstances. John T. Fitzgerald, Cracks in Earthen Vessels: An Examination of the Catalogues of Hardships in the Corinthian Correspondence (SBL Dissertation Series 99; Atlanta: Scholars Press, 1988), 34. Within the Pauline literature, the peristasenkataloge emphasizes Paul's "suffering, privation, and toil." Fitzgerald, Cracks in Earthen Vessels, 46. For a detailed examination of peristasis in its Hellenistic context see the preceding work, 33-46.

${ }^{6}$ See John Howard Schütz, Paul and the Anatomy of Apostolic Authority (SNTSMS 26; Cambridge: CUP, 1975), 182-183.

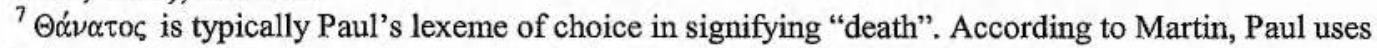

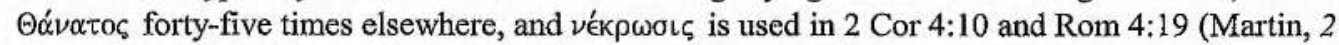

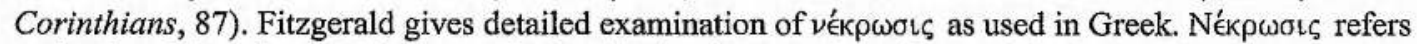
to dead or dying tissue. What is emphasized is the degenerating effects of death from the loss of vitality and power in the living to the culmination of the process in rigor mortis. Thus, Paul "is using one of the starkest words at his disposal" (Fitzgerald, Cracks in Earthen Vessels, 178). As an evocative word with a wide range of meaning, pin-pointing Paul's particular use is difficult and Fitzgerald gives three possibilities. 1) Paul is denoting Jesus in his dying. 2) Paul is referring to Jesus' post-mortem state-an interesting allusion to Paul as "pall-bearer" is explored. 3) Paul is referring broadly to Jesus' dying and death. Fitzegerald opts for the third option (179). "In any case, Paul carries the nekrösis of Jesus in his own body (4:10). This suggests what 4:12 makes explicit, viz., that the nekrösis of Jesus in his body entails his own mortification. Since death is at work in him, how own body is slowly deteriorating and decomposing" (179).

${ }^{8}$ Paul's "carrying about in his body the death of Christ" alludes to 2:14-17 as Paul describes his own "being lead about in triumphal procession" as an aroma of Christ to God. This aroma takes the smell of death to those who are perishing and of life to those who are being saved. See Hafemann, Suffering and the Spirit, 41-58; Fitzgerald, Cracks in Earthen Vessels, 179; Schütz, Paul and the Anatomy of Apostolic Authority, 210-211. On Paul, metaphor, and theology in 2 Corinthians see Steven J. Kraftchick, "Death in Us, Life in You: The Apostolic Medium," SBL Seminar Papers, 1991, 618-637. ${ }^{9}$ Schütz, Paul and Apostolic Authority, 242-243. See also Hafemann, Suffering and the Spirit, 71.
} 
"We do not preach ourselves but Christ Jesus the Lord" (2 Cor 4:5). Paul's preaching of Christ entails with it the sufferings of Christ (2 Cor 5:14-21) as God's means of reconciliation, and within the eschatological tension of Paul's "already/not yet" his own sufferings are intricately connected to God's continuing work of reconciliation in Christ. ${ }^{10}$ Thus Paul's sufferings are not his demise but the means of God's life-giving renewal in revealing the sufferings of Christ. What is of import to note is that Paul's sufferings find their validity in their connection to and subordination under the sufferings of Christ. ${ }^{11}$

The I $\nu \alpha$-clause of 4:11 points to the purpose of Paul's sufferings-the revelation of the life of Christ. In other words, "in his [Paul's] weakness God's power shines through."12 Paul's sufferings, as linked to the sufferings of Christ, are a part of God's plan of reconciliation, as observed in the Peristasenkataloge of both 4:8-9 and 6:3-10. Wood's comment seems apt at this point: "If in Romans and Galatians we see the apostle proclaiming the cross with might and main, in 2 Corinthians we see him bearing the cross, and bearing it triumphantly." ${ }^{13}$ With this said, it must be emphasized again that Paul's sufferings do not have validity as suffering for suffering's sake alone, but suffering as subordinated to and organically linked with the sufferings of the Servant, Jesus Christ.

2 Cor 6:3-10 is placed within the flow of Paul's argument in 2 Cor 5:116:10-Paul tops and tucks his discussion in $5: 12$ and $6: 4$ by use of the root word

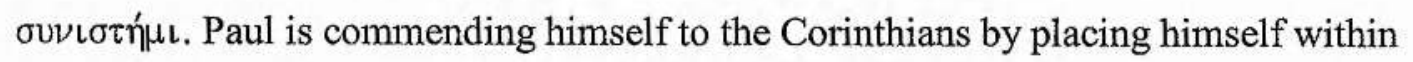
God's redemptive program as he presses forward the validity of his own suffering and apostolic ministry in light of God's continuing work in Christ (5:14-21). Furnish states, "Most especially, however, there is no reason to separate 6:3-10 from 5:20-6:2; the two passages are in fact organically related." ${ }^{14}$ Thus $6: 3-10$, literarily, is a

\footnotetext{
${ }^{10}$ Hafemann, Suffering and the Spirit, $71-72$; Bockmuehl describes Paul's affirmation of Christian virtues, including humility, meekness, love, joy or peace as a metamorphosis of virtues affirmed in a Graeco-Roman society. In fact, the Stoics would have found Christ-like virtues such as meekness and humility derisive (Markus Bockmuehl, Jewish Law in Gentile Churches: Halakhah and the Beginnings of Christian Public Ethics [Grand Rapids: Baker, 2000], 138, 140).

${ }_{11}^{11}$ Schütz, Paul and Apostolic Authority, 244.

${ }^{12}$ Schütz, Paul and Apostolic Authority, 244.

${ }^{13} \mathrm{John}$ E. Wood, "Death at Work in Paul" in EvQ 54 (1981), 151. Wood overstates the issue, for Paul does proclaim the cross in 2 Corinthians (e.g. 2 Cor 5:14-21). With that said, the thrust of Wood's statement is received.

${ }^{14}$ Furnish, II Corinthians, 353; see also Bultmann, Second Corinthians, 168. Manus observes the following structure in 5:11-6:10:

a. 5:11-13 - treats of Paul's self-defense

b. 5:14-21 - presents Paul as an ambassador of Christ
} 
climactic section in Paul's self-defense, ${ }^{15}$ and is theologically/eschatalogically connected to his preceding thoughts, the reconciliation of mankind by the suffering Christ.

As has been argued in the preceding chapter, 5:14-21 is a central text for Paul in his self-apologetic for it places Paul's ministry of reconciliation under the rubric of God's reconciling activity in Christ. Paul's ministry, therefore, is a ministry of reconciliation firmly placed within God's eschatologically redemptive activity in Jesus. Manus states, "His defense is formulated in terms of reiterating his fundamentally antithetical view of a theologia crucis in which the suffering of Christ is central; a fact which gives rise to a view of Christian ministry authenticated by suffering and dying daily with Christ." 16 A theologia crucis is an apt phrase for Paul's thought within 2 Cor 5:14-6:10. Paul's reflection on the person and work of Christ in 5:14-21 is a robust account of his affirmation of God's breaking into the world of humanity by the person of Jesus Christ. Coupled with this reality is the paradoxical nature of God's reconciling activity. God reconciles the world to himself-the great reversal of fortunes described in 5:21-by means of the sacrificial giving of the Christ-pre-figured in the Servant of Isaiah 40-55. Though Paul does not use the language of the cross per se in 5:14-21, the reality of God's self-giving in death and resurrection $(5: 14-15,21)$ metalyptically points to the cross. Paul's emphasis on union with Christ in his suffering is for Paul the most persuasive of arguments in an apostolic self-defense. "To be united with Christ means that the minister will have to suffer as Christ did. Through all his trials he really participates in the sufferings of Christ." ${ }^{17}$ God's means of reconciling the world was by the suffering of the Christ. God's continued means of proclaiming the concrete fact of reconciliation is by the

a1. 6:1-10-rehearses Paul's self-defence.

Ch. Ukachuku Manus, "Apostolic Suffering (2 Cor 6:4-10): The Sign of Christian Existence and Identity" in AJT 1 (1987): 44; Hughes, Paul's Second Epistle to the Corinthians, 42. Manus marks "b" as the central unit dealing with Paul's position in the Heilsgeschicte, and in the "a" units Paul depicts his apostolic career and his concept of Christian suffering. Manus, "Apostolic Suffering," 42. Manus" structural observation is well received for it deals with Paul's overarching concern of both the literary unit and the epistle, his apostolic apologetic coupled with his emphasis on Paul's apostolic apologetic as rooted in his Christology of suffering.

${ }^{15}$ Manus cites a litany of commentators' praising remarks of this pericope in Paul's writings. Hughes states, "This movingly beautiful hymn-like passage (2 Cor 6:4-10) flows form the deep heart of the Apostle's knowledge and experience. Its almost lyrical intensity, its structural balance, and its genuine spontaneity have called froth the response of admiration and gratitude in all generations." Op. cit. Manus, "Apostolic Suffering", 44.

${ }^{16}$ Manus, "Apostolic Suffering," 42.

${ }^{17}$ Lambrecht, Second Corinthians, 114. 
agency of the apostle who lives a life demonstrating the death of Jesus Christ for the other, that is, in his suffering for the benefit of the other.

2 Corinthians 5:(11)14-6:10 is a literary unit at the climax of Paul's selfdefense in 2 Cor 2:14-7:1. The purpose of the unit is to continue Paul's self-defense in light of his suffering and apparent weakness. The foundation of the unit is the central characterization of God's reconciling activity by means of the suffering and selfgiving of the divine agent, Jesus Christ. Paul places himself in the midst of this eschatological now, and subordinates his own suffering and apostolic ministry under the larger rubric of the sufferings of Christ-sufferings both completed and continuing in the ministry of Paul. Within the redemptive drama of Isaiah, the typological fulfillment of the Servant as alluded to in 2 Cor 5:14-21 and as invited into by 2 Cor $6: 2$ is found in Christ - the only agent able to carry the weight of such a redemptive, typological task.

Regarding Paul's eschatological placement and identity, Hughes proleptically alludes to the conclusion this thesis seeks to address with the following statement: "In the faithful discharge of his apostolic office Paul, the servant of the Servant, had made himself their servant, and they had been brought into participation of the eschatological messianic kingdom and all its blessing" (emphasis mine). ${ }^{18}$ Though Hughes seems to use the phrase "the servant to the Servant" as an ad hoc literary device, his statement does pick up the tension within the passage and points to a way forward in our understanding of the redemptive drama of Isaiah 40-66 as a figural presentation of both Christ the Servant and Paul, a servant of the Servant. Our attention, therefore, turns to Isaiah's portrait of these servants of the Servant in Isaiah 53-66.

\section{The Servants to the Servant in Isaiah 53-66}

A movement takes place within the dramatic narrative of Isaiah $40-66$ as the focus on the Servant (singular) of Isaiah 40-55 shifts to a focus on the servants (plural) of Isaiah 54-66. ${ }^{19}$ As Beuken has observed, "The connection is not fortuitous. In the last

\footnotetext{
${ }^{18}$ Hughes, Paul's Second Epistle to the Corinthians, 220.

${ }^{19}$ With Childs, this project affirms "the recent move (cf. Beuken, Rendtorff, Steck) to interpret 56-66 as part of a larger literary collection rather than to assume its function as an independent corpus that is only peripherally connected to the larger book of Isaiah" (Childs, Isaiah, 441). Childs has emphasized the role of intertextuality as an illuminating force in one's reading of Isaiah 56-66 which shows the "close dependency" of 56-66 on 40-55 (Isaiah, 442). Childs (442) continues, "I would argue that the citations and allusions, far from attempts to correct Second Isaiah's perspective, serve to call attention
} 
text involving the Servant, he is promised that 'he shall see offspring' (53.10), but when and how this will happen remains open. ${ }^{20}$ The servants are introduced for the first time in Isa 54:10, "This is the heritage of the servants of the Lord, and their vindication is from me." The connection between the Servant and servants is a strong linking of the central message of 52:13-53:12 as a continuing force now carried out by the servant followers of the Servant. ${ }^{21}$ Within the narrative, the Servant's pressing message of God's "new thing" is carried out by the "heritage of the servants," those who have responded in obedience to the call of the Servant in 50:10. In chapter 53, they confessed their transformation on the basis of the suffering Servant's work on their behalf. Now, in chapter 54 they are receiving their vindication from God. This group of obedient followers of the Servant is, if not the, a major theme in Isaiah 54$66^{22}$ Those scholars who have given the greatest amount of attention to the servants of the Servant are Beuken, Seitz, Childs, and from a historical-sociological perspective, Blenkinsopp. This project is working within a literary/synchronic framework and will respectively lean quite heavily on the work of Beuken, Childs, and Seitz as the theme of the servants of the Servant is explored within the movement of Isaiah's latter chapters.

to Second Isaiah as an authoritative warrant and offer support for his continuing use of the same material." Isaiah 56-66 continues the prophetic announcement of God's "new thing" (65:17) which is in close continuity with Isaiah 40-55. Seitz has argued that the servant followers of the Servant actually composed 52:13-53:12 and this section serves as the center of Isaiah 40-66. Thus, chapter 54 is the opening chapter of the final section of the book (Seitz, "Isaiah 40-66," 474). Also, for Seitz, there is no time gap between Isaiah 40-55 and 56-66. "With the death of the servant, the servants' work begins" (Seitz, "Isaiah 40-66," 474). This project will continue with its focus on the literary aspects of the text in its final canonical form, the position Paul takes in his reading. See also, R.F. Melugin, The Formation of Isaiah 40-55, BZAW 171 (Berlin: Walter de Gruyter, 1988); R. Rendtorff, "The Composition of the Book of Isaiah," in Canon and Theology (Minneapolis: Fortress Press, 1993), 146169; C. Westermann, "Structure and Composition of Chapters 56-66," Isaiah 40-66, 296-308; Leclerc, Yahweh is Exalted in Justice, 131-132; P.A. Smith, Rhetoric and Redaction in Trito-Isaiah: The Structure of Growth and Authorship of Isaiah 56-66 VTSupp 62 (Leiden: Brill, 1995). It should also be stated that for sake of familiarity, the collocation Isaiah 40-55 will be retained as a literary indicator while at times Isaiah 54-66 will be used to describe the arriving on the scene of the servants theme. ${ }^{20}$ W. Beuken, "The Main Theme of Third Isaiah: 'The Servants of Yahweh'," JSOT 47 (1990), 67-87.

21 "Now here, on the other side of the servant's death, the servants take up where the servant left off." Seitz, "Isaiah 40-66," 476.

${ }^{22}$ Beuken, "The Main Theme"; "An Example of the Isaianic Legacy of Trito-Isaiah," in Tradition and Re-Interpretation in Jewish and Early Christian Literature: Essays in Honor of Jurgen C. H. Lebram. ed. J. W. van Henton et al. (Leiden: Brill, 1986), 204-221; Joseph Blenkinsopp, "The 'Servants of the Lord' in Third Isaiah: Profile of a Pietistic Group in the Persian Epoch," in This Place is Too Small For Us, 392-412; Knud Jeppesen, "From 'You, My Servant' to 'The Hand of the Lord is with My Servants'," SJOT 1 (1990). 113-129; Seitz, Figured Out, 115. It should be noted that other 


\section{3.a. Isaiah 56:1-8}

Much discussion has been given to this pericope. Certain interpretations have centered on a particular historical reconstruction behind the text as the hermeneutical filter (e.g. Whybray, Blenkinsopp). Issues of genre, however, need be kept in the forefront as one deals with this text. For as Muilenberg reminds us, "We are dealing with poetry in an eschatological context." ${ }^{23}$ Thus it is important to differentiate between literary/canonical function and diachronic function which presupposes certain dates and provincial settings. ${ }^{24}$ The literary function of Isa $56: 1-6$ is, according to Beuken and Childs, a setting of the stage for the final chapters of Isaiah which themselves focus on the "red thread" of the servants of Yahweh. ${ }^{25}$

Beuken maintains that the theme of the "servants" is given a "programmatic place" in Isa 56:6. ${ }^{26}$ Isaiah 56:1 emphasizes righteousness as God's aim for his servants. ${ }^{27}$ The sense of the text is quite different from Isaiah 40-55 as certain cultic duties are emphasized. This emphasis does not negate the promise of God given in Isaiah 51:5-6 concerning righteousness as the gift of God but presupposes it with an emphasis on the people of God's covenant responsibility. Seitz has made an intertextual appeal to Isa $1: 27$, which states, "Zion shall be redeemed by justice, and those in her who repent, by righteousness." ${ }^{28}$ Childs observes an intertextual relation between 56:1-2 and 46:12-13. "Listen to me, you stubborn of heart, you who are far from deliverance: I bring near by deliverance, it is not far off, and my salvation will not tarry; I will put salvation in Zion, for Israel is my glory." ${ }^{29}$ Isaiah 40-55 promises salvation on the basis of God's gracious covenant faithfulness, but, this promise is misunderstood if it is not conjoined with obedience or covenant faithfulness. As Oswalt states, "The point is followed out throughout the section: human obedience

important themes are at work in Isaiah 56-66. This project is working with the theme of the servants of the Servant. See Childs, Isaiah, 446-447.

${ }^{23}$ Op. cit. Childs, Isaiah, 453.

${ }^{24}$ Childs, Isaiah, 453.

${ }^{25}$ Beuken, "The Main Theme," 68-69; Childs, Isaiah, 455.

${ }^{26}$ Beuken, "The Main Theme," 68.

${ }^{27}$ צֶ was linked with God's covenant faithfulness in 40-55, but "we are no longer talking about righteousness as an expression of God's right dealing in regard to covenant or even about a declaration of a righteous condition in the people of God. Rather the command to do righteousness makes it very plain that we are once more, as in chaps. 1-39, speaking of God's expectation of certain kinds of behavior from his people" (John N. Oswalt, "Righteousness in Isaiah: Chapters 56-66," in Writing and Reading the Scroll of Isaiah-I, 187).

${ }^{28}$ Seitz, "Isaiah 40-66," 485.

${ }^{29}$ Childs, Isaiah, 456. 
should be the natural result of divine faithfulness." ${ }^{30}$ Also, $56: 1$ creates an atmosphere of continued eschatological hope. Readers are not made aware of a "different

historical period" but perhaps a slight shift in emphasis, an emphasis on the necessity of obedience. "The word delivered to them is that all who do justice and

righteousness and hold fast to the divine covenant are God's servants." ${ }^{31}$ Those who are obedient are God's servants.

With Jeppesen, however, we are quickly reminded, "The sabbath is a little surprising [cultic/covenantal responsibility]....but the big surprise is that among the possible servants are 'foreigners who have joined themselves to the Lord' (v.3).",32 The more opaque theme of the inclusion of the gentiles in the people of God in Isaiah 40-55 now becomes an apparent reality in the setting of the "new things." The intertextual allusion to Isa 2:2-4 resonates loudly as one observes foreigners being brought into God's holy mountain. The textual picture is one of fulfillment in God's new redemptive activity and a filling out of the vague concept of "the many" in Isa $53: 11-12 .^{33}$ In $56: 6$ the purpose of the foreigner's attachment to Yahweh is delineated. They are to worship and love Him, obey Him, and be his servants. ${ }^{34}$ God's new redemptive activity by means of the Servant is fleshed out in more detail in 56:1-6 as covenant fidelity is emphasized. Alongside this emphasis on covenant fidelity is the making possible of the inclusion of all foreigners who yield their complete devotion and service to Yahweh. ${ }^{35}$

\section{3.b. The Servants in Isaiah 56:9-63:6}

At first glance, the servants seem absent from this particular section of Isaiah. The term עבד is missing from the material and does not reappear until 63:17. ${ }^{36}$ Beuken,

\footnotetext{
${ }^{30}$ Oswalt, "Righteousness in Isaiah," 188.

${ }^{31}$ Seitz, "Isaiah 40-66," 485.

32 Jeppesen, "From 'You My Servant'," 126-127.

${ }^{33}$ Beuken, "Isaiah Chapters LXV-LXVI," 205.

${ }^{34}$ Seitz states, "The prophet has not drifted off into abstraction and sentimentality, change for change's sake. The opening appeal is sober and direct: Maintain justice and do what is right. The context for these matters comes from the teaching God had promised long ago to share with the nations (Isa 2:3). Justice and righteousness are not virtues to be summoned up from our natural sense of equality and fair play. They are linked with attention to what God requires of us and obedience to God's instruction" (Seitz, "Isaiah 40-66," 486). See also, Leclerc, Yahweh is Exalted in Justice, 133-138.

${ }^{35}$ For detailed interaction with historical reconstructions of this text, see Childs, Isaiah, 452-455, 457458; Smith, Rhetoric and Redaction in Trito-Isaiah, 50-66.

${ }^{36}$ The unity of this section (most particularly 56:9-57:21) has been highlighted by the following: Seitz, "Isaiah 40-66," 489; Smith, Rhetoric and Redaction in Trito-Isaiah, 68-71; G. Polan, In the Ways of Justice Toward Salvation: A Rhetorical Analysis of Isaiah 56-59 (New York: Peter Lang, 1986); Benjamin D. Sommer, A Prophet Reads Scripture: Allusion in Isaiah 40-66 (Stanford: Stanford
} 
however, notes two particular terms that are in close association with the semantic

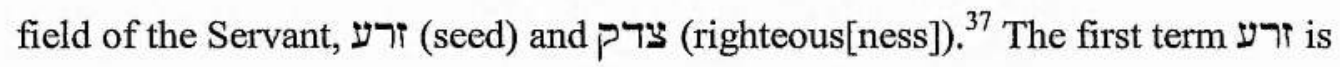
located in Isa 53:10 as the semantic indicator of the offspring promised to the Servant, who in turn become the servants. ${ }^{38}$ The second term צרק is connected with "the seed" in 45:25 and 48:18 and also with the Servant (especially Isa 53). "For according to DI [Deutero-Isaiah], God guarantees that the Servant will excel in 'righteousness' and will transfer it to those who belong to him, so that 'righteousness' will also become the essence of their life (53:11f.; 54:17)."39

Thus for Beuken the absence of the term "servants" in 56:9-63:6 is functional, an aposiopesis. For in Isa 56:9-63:6 a conflict takes place between the righteous and the godless. In the first main section, 56:9-59:21, "the theme of the contrast between the righteous and the godless" play a central role. ${ }^{40}$ The second main section, 60:1$63: 6$, the righteous are shown their particular place in God's program. ${ }^{41}$ Beuken has persuasively argued that it is in the form of these "righteous ones" that the servants, the offspring of the Servant, are found. ${ }^{42}$

\section{3.b.i. The First Main Section: 56:9-59:21}

The struggle between the righteous and the wicked coupled with their distinct fates is portrayed in this passage $(56: 9-12 ; 57: 1-2 ; 57: 3-13 ; 57: 14-19 ; 57: 20-21) .{ }^{43}$ Only the righteous will enjoy "peace" (Isa 57:2;21), while for the wicked "there is no peace" $(57: 21)$. Also, the watchmen of Isa 56:10 are declared blind. It is recalled that in 40:111 and 52:7-12 the watchmen had a role in declaring to the people the return of Yahweh to Zion, but now the watchmen are blind and lacking knowledge. Moreover, Isa $56: 11$ echoes the situation of the Servant in 53:6. In 53:6 the sheep go their own

\footnotetext{
University Press, 1989), 187-192. Also, the intertextual nature of this material has been observed by Childs, Isaiah, 462-464; Seitz, "Isaiah 40-66," 489; Beuken, "The Main Theme;" Mark E. Biddle, "Lady Zion's Alter Ego: Isaiah 47:15 and 57:6-13 as Structural Counterparts," in New Visions of Isaiah (JSOTS 214; ed R. Melugin and M. Sweeney; Sheffield: Sheffield Academic Press, 1996), 124-139.

${ }^{37}$ Beuken, "The Main Theme," 68; "Isaiah Chapters LXV-LXVI," 206.

${ }^{38}$ See Childs, Isaiah, 419; Seitz, "Isaiah 40-66," 467; Beuken states, "Before the fourth Servant Song, Israel is addressed as 'the seed' of the patriarchs (Abraham: 41.8; cf. 51.2; Jacob-Israel: 45.19), which will itself have offspring $(43.5 ; 44.3 ; 49.19)$, bur from $53: 10$ on the promise of posterity regards the Servant and the new city (54:3)" (Beuken, "The Main Theme," 68).

${ }^{39}$ Beuken, "The Main Theme," 68.

${ }^{40}$ Beuken, "The Main Theme," 69.

${ }^{41}$ Beuken, "The Main Theme," 69.

${ }^{42}$ Beuken, "Isaiah LXV-LSVI," 206; "The Main Theme," 69.

${ }^{43}$ Seitz, "Isaiah 40-66," 489.
} 
way, whereas in 56:11, the shepherds (the leaders) are turning to their own way. ${ }^{44}$ The picture portrayed in 56:9-12 is that of a people in disarray perverting the feast of grace offered in Isaiah 55 . $^{45}$

As has been mentioned, Isa 57:1-13 presents the wicked and righteous in antithesis. Isaiah 57:1-2, 13b reveals the state and fate of the righteous, with 57:3-13a portraying the wicked in their state of covenantal adultery. This particular antithetical circumstance has resulted in the suffering of the righteous. Seitz observes, "This sort of affliction, first visited on the servant (50:4-9; 52:13-53:12), has not come upon the servants." ${ }^{46}$ This was pointed to in 50:10, where the obedient responders to the Servant are encouraged to put their trust in God. The peace resulting from the vicarious suffering of the Servant is received in Isaiah 57 by the righteous servants. It is those who have responded and are responding in trust and obedience to Yahweh who receive the benefits afforded them by the Servant, e.g. peace. The servants of the Servant suffer in righteousness as did the Servant. They carry out his faithful and obedient response to Yahweh in the midst of a faithless and godless generation resulting in their own suffering. Commenting on 57:2, Seitz states, "What is clear is that righteous suffering and affliction can lead to death, in ignominy and without concern. This is consistent with the fate of the servant as confessed by the servants (53:3). The servant was to make many righteous (v. 11); the fate that was his is shared by those who follow in his way." 47 The offspring of the Servant inherit the Servant's faithful suffering. ${ }^{48}$

\footnotetext{
${ }^{44}$ Beuken, "The Main Theme," 69-70; Seitz, "Isaiah 40-66," 490. Childs observes the resonance of $56: 11$ with $53: 6$ but warns against bringing the figure of the suffering servant into the text's foreground (Childs, Isaiah, 465).

${ }^{45}$ W.A.M. Beuken, "Isa. 56:9-57:13-An Example of the Isaianic Legacy of Trito-Isaiah," in Tradtion and Re-Interpretation in Jewish and Early Christian Literature: Festschrift for J.C.A. Lebram, ed. J. van Henton (Leiden: Brill, 1986), 50-53; Seitz, "Isaiah 40-66," 490.

${ }^{46}$ Seitz, "Isaiah 40-66," 490.

${ }^{47}$ Seitz, "Isaiah 40-66," 490-491.

${ }^{48}$ Biddle gives an interesting reading to this section. He identifies the second person, femininesingulars of Isa 57:6-13 with Lady Zion, the personified city. Biddle points to the conceptual overlap of Isa 57 and 47. For in Isa 47 Lady Babylon, "who because of her haughtiness and cruelty must fall in order to make room for the restoration of Lady Zion to the throne and to permit the return of her children" (Biddle, "Lady Zion," 137). However, the Lady Zion presented in Isaiah 57 is Lady Zion's alter ego, "the old, sinful, unfaithful harlot upon whom Yahweh visited judgment" (Biddle, "Lady Zion," 138). Babylon's fall did not automatically trigger Zion's restoration. "Babylon has fallen, but so, too, must the Old Jerusalem" (Biddle, "Lady Zion," 139). Biddle (139) concludes, "Old Jerusalem cannot simply be restored, she has not changed since the days of the first Isaiah nor since the exile; there must be a New Jerusalem. As Babylon fell, so must the harlot Zion. Jerusalem will not be restored, but replaced: a new heaven, a new earth, a new Jerusalem."
} 
Chapters 58 and 59 expose the people's $\sin (58: 1-5)$ and call for their repentance (58:6-14). Salvation is presented as near in Isaiah 40-55, but, in Isaiah 59 the picture is quite different. The feet of the people rush into $\sin (59: 7)$; therefore justice and righteousness are far from them (59:9). ${ }^{49}$ The righteous, the servants, mourn in penitence as God himself is pictured as the one working salvation for the repentant (59:11-17). Isaiah 59:18-20 brings comfort to the penitent ones, as they are reminded that the Redeemer (אוֹ sins. ${ }^{50}$ Childs states,

In sum, the chapter focuses on a theological summary of the full extent of Israel's apostasy as it probes the devastating dimensions of $\sin$ and evil. The faithful within the nation, who are fully enmeshed in Israel's self-destructive fate, throw themselves completely on God's mercy without offering any mitigating excuses. They know and acknowledge their share in Israel's guilt. The ensuing theophanic description of the divine response, retrojected into the past, establishes once and for all that God alone can shatter the power of sin and bring justice and salvation to suffering Zion. There is no other force to intercede. ${ }^{51}$

A commissioning scene is found in 59:21 as the focus of the commission now centers on the offspring of faithful Israel, the servants (cf. 44:3) ${ }^{52}$ A distinct line of demarcation is drawn between the "seed of the harlot" (57:3) and the "seed of your seed" $(59: 21))^{53}$ "In these generations the promise is realized that the Servant "shall see offspring (seed)' and prolong his days' (53:10)." ${ }^{54}$ The presence of the faithful penitent, the servants, in the midst of the unfaithful generation is the demonstration of God's faithfulness to his covenant. ${ }^{55}$ Having been reminded of God's will to be with them by His Spirit, the servants continue in faithful obedience to the divine commission propelled by the hope of God's continued presence with them.

\footnotetext{
${ }^{49}$ There is a shift to the first person plural in 59:9. Childs presents this shift as a "completely different perspective" from the "voice of faithful Israel" as they "transform the complaint into a confession" (Childs, Isaiah, 488). Seitz takes a similar position as he opines that the first-person plural is the voice of the prophet on behalf of the righteous among the people (Seitz, "Isaiah 40-66," 501).

${ }^{50}$ Childs, Isaiah, 489.

${ }^{51}$ Childs, Isaiah, 490.

${ }^{52}$ The association of the covenant with the servants in 56:5-6 should not be missed (see Childs, Isaiah, 490; Seitz, "Isaiah 40-66," 502). Seitz maintains that it should not be surprising to find a long speech in 61:1-4 where the prophetic "I" steps up and speaks. This speech flows from the scene in 59:21.

${ }^{53}$ Beuken, "The Main Theme," 70.

${ }^{54}$ Beuken, "The Main Theme," 70.

${ }^{55}$ Seitz, "Isaiah 40-66," 502-503; Childs, Isaiah, 490.
} 


\section{3.b.2. The Second Main Section: 60:1-63:6}

Isaiah 60-62 flows from the faithful confession of $\sin$ and guilt within obedient Israel, i.e., the righteous servants. Within these chapters the effects of the promise given in 59:21 takes shape. ${ }^{56}$ The promise of the coming of the redeemer given in 59:20 is actualized in 60:1-3, 16. Clements reminds us that "the message [of Isaiah 60] is pure poetry, replete with metaphorical imagery about the coming of light to dispel darkness and reveal the divine glory." ${ }^{, 57}$ The picture portrayed in Isaiah 60 is one of intense imagery bordering at times on apocalyptic. ${ }^{58}$ Westermann portrays $60: 17-22$ as "apocalyptic" whereas the rest of the chapter "never transcends the confines of this world and of history." 59 Seitz warns against drawing the distinctions Westermann has drawn between apocalyptic and real history.

We must not let the dramatic and enthusiastic poetic force of the material be translated too quickly into social and mundane realities...It [the material witness of Isaiah] is not content, in the manner of its own expression, to set forth a program, whose point-by-point completion can be monitored. It is God's statement from the prophet about divine final intentions for Israel, Zion, and the nations. Its accomplishment will be swift, according to a time only God knows. ${ }^{60}$

Isaiah 60 extends the theological vision of Isaiah 40-55 making use intertextually of many themes found therein. ${ }^{61}$ Beuken summarizes the presence of the servants in 60:1-63:6 in the following way: "In these chapters the prophet announces a righteous generation, in which the promise to the Servant will come true."62

Intertextually, Isa 60:1-3 echoes the vocation of the Servant which is now transferred to Zion, possibly forming an inclusio of sorts with Isa $2: 2-5 .^{63}$ It is recalled

\footnotetext{
${ }^{56}$ Childs, Isaiah, 494. On the redactional question see, Smith, Rhetoric and Tradition, 26-38, who concludes that there is insufficient grounds for removing any substantial portions of the material of 6062 and ascribing them to later redactors (38); Ronald Clements, "Arise, Shine; For Your Light Has Come," in Writing and Reading the Scroll of Isaiah-I, 441-454; O.H. Steck, "Der Grundtext in Jesaja 60 und sein Aufbau," in Studium zu Tritojesaja, (BZAW 203; Berlin: Walter de Gruyter, 1991), 49-79. ${ }^{57}$ Clements, "Arise Shine," 444.

${ }^{58}$ Westermann, Isaiah 40-66, 363-364; Seitz, "Isaiah 40-66," 510.

${ }^{59}$ Westermann, Isaiah 40-66, 363.

${ }^{60}$ Seitz, "Isaiah 40-66," 510; also see Clements on the "unfulfilled nature" of Isaiah 60, Clements, "Arise Shine," 446.

${ }^{61}$ Beuken, "The Main Theme," 70; Childs, Isaiah, 495; Steck, "Der Grundtext," 49-79; Seitz, "Isaiah $40-66, " 508$.

${ }^{62}$ Beuken, "The Main Theme," 70.

${ }^{63}$ Beuken, "The Main Theme," 70; Seitz, "Isaiah 40-66," 508; Clements, "Arise Shine," 454; Childs, Isaiah, 496. The overlap between Isaiah 60 and 40-55 is stark. One notes the promises given of God's inbreaking glory, the flowing of the nations to Zion, and the renewal of the people of God. Childs insightfully states, "I would argue that Third Isaiah strongly confirms the promises of Second Isaiah,
} 
that the Servant is to be a "light to the nations" (Isa 49:6) and the Servant is acknowledged by the nations and kings (Isa $52: 15$ ). ${ }^{64}$ Zion is now fulfilling this role. Zion, however, has been defined in 59:20-21 as composed of those who are the repentant of Israel, the faithful/righteous ones. Beuken states, "If one realizes here that Zion takes over the function of the Servant, then one should obviously examine whether perhaps its inhabitants show the features of the offspring of the Servant." ${ }^{, 65}$ Isa 60:21 portrays the people of Zion as righteous. This term 13 characterizes the servants of Isaiah 53-66. Isaiah 57:1 and 60:21 are the sole instances of the term "righteous" as applied to a specific group in Isaiah 56-66-the oppressed, sufferers in the community who have chosen to "walk along the straight road." 66 The ignominious group of suffers who have responded obediently to the call of the Servant (50:10ff) are promised to become a "mighty nation" in 60:22. ${ }^{67}$ This theme continues in Isaiah 61.

Isaiah 61 is placed contextually in the midst of God's eschatological activity of restoring Zion, specifically, a Zion composed of the righteous servants (57:1; $59: 17 ; 60: 21)$ who have responded faithfully in repentance $(59: 20) .{ }^{68}$ Beuken's point, followed by Childs and Seitz, deserves a broad hearing. That is, "in the speaker of chapter 61 the offspring of the 'suffering servant' of chapter 53 is embodied, who can be an individual as well as a collective entity." 69 The particularity of the historical personage behind the text-e.g. Trito-Isaiah-is not present within the text. What is found, however, is a coalescing of the features attributed to both the Servant and Herald of Isaiah 40-55. ${ }^{70}$ This figure brings a message of comfort (cf. Isa 40:1-31) to those who are faint (cf. Isa 42:2-3), proclaiming (cf. Isa 40;9; 52:7) the eschatological

and shares his anticipation of a coming kairos. Yet there is a difference. Third Isaiah no longer identifies the deliverance of the exiles from Babylon as coterminous with the entrance of God's kingdom. Indeed, Babylon has receded into the background as has the new exodus. It has become only an instance of the promise. Rather, what now lies ahead has become radically eschatologized. The new Jerusalem is not a rebuilt city, but the entrance of the divine kingdom of God, the creation of a new heaven and earth." Childs, Isaiah, 500.

${ }^{64}$ Seitz, "Isaiah 40-66," 508.

${ }^{65}$ Beuken, "The Main Theme," 70-71.

${ }^{66}$ Beuken, "The Main Theme," 71.

${ }^{67}$ Childs, Isaiah, 499.

${ }^{68}$ For various formulations of a form-critical reading of Isaiah 61 see the overview given by Childs, Isaiah, 502-503.

${ }^{69}$ Childs, Isaiah, 503; Beuken, "The Main Theme," 71; Seitz, "Isaiah 40-66," 513; Smith, Rhetoric and Redaction, 24-25.

${ }^{70}$ Beuken, "The Main Theme," 71; W. A. M. Beuken, "Servant and Herald of Good Tidings: Isaiah 61 as an Interpretation of Isaiah 40-55," in The Book of Isaiah (BETL 81; Leuven: Leuven University Press, 1989), 411-440. 
now of God's redemptive activity. Seitz posits, "The intertextuality is not just a technique to be traced out, but has important implications for the prophet's own selfunderstanding.,"71 This particular portion of Isaiah highlights the overlap yet distinction between the servants and the Servant.

The activity of the Servant and the message of the Servant are carried out by the faithful seed (61:9) who are the servants. In Isa 44:2b-3 the Spirit is promised to Jacob, my servant and his offspring. This promise is reiterated in 59:21. Thus, "The voice which then announces in 61:1 that the spirit is upon him is thereby identifying with 'the heritage of the servants of Yahweh' (Isa 54:17)."72 The mission of this figure is closely linked with the mission of the Servant (Isa 53:10-12) as he seeks to bring fulfillment to the promise of a people who are wholly righteous (Isa 61:3). ${ }^{73}$ "The work of the servant is being accomplished in the next generation, and in generations to come." ${ }^{74}$ The offspring of the Servant, embodied in the faithful servants, are intricately linked to the continuation of the work and mission of the Servant, for it is in the servants that the Servant continues to live. ${ }^{75}$ This is especially highlighted in the fact that the figure (a member of the servant followers of the Servant) presented in Isaiah 61 proclaims the year of the Lord's favor (Isa 61:2). This is an allusion to Isa 49:8 where the Servant himself proclaims a similar message, "now is the day of salvation." The servant followers of the Servant proclaim the same eschatological message which is now linked with the person and mission of the Servant. $^{76}$

The actualization of the work of the Servant is carried out faithfully by the servants as they continue the work of the Servant as heralds. They are his offspring, the product of his faithful response to God's call of suffering for others. ${ }^{77}$ The overlap between the mission of the Servant and the servants is brought to the foreground in

\footnotetext{
${ }^{71}$ Seitz, "Isaiah 40-66," 514.

${ }^{72}$ Childs, Isaiah, 504.

${ }^{73}$ Beuken, "The Main Theme," 72.

${ }^{74}$ Seitz, "Isaiah 40-66," 515.

75 Beuken, "The Main Theme," 72.

${ }^{76}$ Beuken, "Servant and Herald," 425 . This particular overlap of messages - the proclamation of the year of the Lord's favor-is another example of the way in which attention to the larger movement within the book of Isaiah as a whole (40-66) may alleviate the tensions present in the readings offered by Beale, Webb, and the others mentioned in previous chapters.

${ }_{77}$ Childs, commenting on Jesus' use of Isa 61 in Luke 4, states, "Rather, a case can be made that Jesus himself ushers in the acceptable year of the Lord, and thus the citation of Isaiah 61 encompasses the entire mission of the servant, including his life, death, and offspring" (Childs, Isaiah, 508). See also, Craig A. Evans, "The Function of Isaiah in the New Testament," in Writing and Reading the Scroll of Isaiah-II, 687-691.
} 
this particular text. This relationship is one of organic unity with the servants taking a subordinate role to the Servant. Their message is the message of the Servant.

Beuken maintains that the theme of the "righteous offspring of the Servant" continues to play an integral role in Isaiah $62 .^{78}$ The use of the first person singular in 62:1-7 has been met with differing opinions. Delitzsch, representative of older commentaries on the passage, identifies the first person singular speech with God. However, in 61:2-3 the speech is addressed to others on behalf of God. Contextually, it is best to understand Isaiah 62 as a continuation of the prophetic oracle having begun in Isaiah $61 .{ }^{79}$ Whereas in Isa $61: 11$, the Sovereign Lord will make righteousness and praise spring up before the nations, in Isaiah 62 this reality is presented in an eschatologically realized sense.

The restoration of Zion is heralded in Isaiah 62 with language reminiscent of the Servant $(62: 2$; cf. 52:15) - the eyes of the nations will be turned toward restored Zion observing its righteousness. "The righteousness the servant was to establish (53:11) is manifested in the servants and the restored Zion., ${ }^{80}$ Thus, the restored Zion is composed of the righteous ones, a term linked with the servants (Isa 56:1-6; 57:1: $59: 21 ; 60: 21)$. Childs is correct to maintain, therefore, that though Isaiah 62 focuses on the restoration of Zion, this is linked with the "Holy People" and the "Redeemed of the Lord" (Isa 62:12). ${ }^{81}$ The anticipated restoration of the servants-both nationals and foreigners - in 56:1-6 is presented as a realized event in 62:10-12. ${ }^{82}$

Isaiah 63:1-6 is a most interesting text and our discussion will remain focused lest we be taken too far afield. ${ }^{83}$ Beuken observes the absence of the "righteous offspring" in this passage. ${ }^{84}$ On a synchronic level, the message heralded forth in 63:1-6 is linked with the preceding passage in the following ways: 1) sentinels are dispatched in 62:1-6 (the message of 63:1 6 may be the cry of these sentinels); 2 ) the

\footnotetext{
${ }^{78}$ Beuken, "The Main Theme," 74.

${ }^{79}$ Childs, Isaiah, 74.

${ }^{80}$ Seitz, "Isaiah 40-66," 515.

${ }^{81}$ Subsequently, in Isa 63:18 the servants are described as those who have possessed the holy place yet are suffering. Childs, Isaiah, 512-513.

82 "Now 'the dispersed of Israel' are assembled in the house of YHWH, together with 'the foreigners'. Altogether they are 'the servants of YHWH' (55.6-8)." Beuken, "The Main Theme," 74. The intertextual echoes in 62:10-12 to 40-55 have been described by Childs as a "virtual catena" and by Seitz as a "virtual collage". The call for preparation and building up a highway, proclaiming of salvation to the ends of the earth, the reward accompanying the returning Yahweh all reflect major themes within Isaiah 40-5 (Childs, Isaiah, 510; Seitz, "Isaiah 40-66," 515).

${ }^{83}$ See Smith, Rhetoric and Redaction, 38-44; Childs, Isaiah, 515-516; Seitz, "Isaiah 40-66," 518-520; Westermann, Isaiah 40-66, 380-384.

${ }^{84}$ Beuken, "The Main Theme," 74.
} 
themes of vindication and the day of the Lord are also present in 61:1 and 62:1-2. Childs emphasizes the bracketing affect of 63:1-6 with 59:15b-20. For in Isa 59:20, the coming of God to Zion as Redeemer has been spoken of. Isaiah 60-62 expands on this theme emphasizing the "future glory of Jerusalem and the good tidings of its afflicted, faithful inhabitants." $" 85$ The function of Isaiah 63 is to demonstrate that God's coming to the faithful inhabitants of Zion is preceded by a most powerful demonstration of diving judgment against the "evil and injustice of those in rebellion against God's rule." ${ }^{86}$ The literary context displays the necessary actions of God in the redemption of his faithful elect.

Debate has ensued over the apparent "universalism" of Isaiah 60-62 and the "nationalism" presented in 63:1-6. ${ }^{87}$ With this said, many interpreters (e.g. Snaith, Holmgren, Westermann) have not been persuaded of the universal character of Isaiah 60-62. Westermann takes a mediating position on the role of the nations, that is, the nations are to come freely from afar, and yet, according to Westermann the universalism of Isaiah 40-55 is dampened by Isaiah $56-66 .^{88}$ On the other hand, Snaith, commenting on Isaiah 60-62, states, "The note of triumph at the expense of and over the Gentiles is clearest of all." 89

For the sake of clarity and brevity, Beuken's insightful argument pertaining to this passage and its "nationalism" will be rehearsed-an argument that, in the opinion of this author, gives the best overall outlook on this passage contextually. ${ }^{90}$ Within Isaiah 58-59 the prophet has portrayed the deep divisions in the people of God. Yet in 59:20, the experience of God as redeemer will come to those in Jacob who turn away from their sins, and in Isaiah 56 this offer has already been extended to the foreigners. Childs, following Beuken, writes:

In contrast, Edom as Jacob's kin and yet archenemy now symbolizes the sharp and enduring division within the household of Israel. The peoples in revolt are not being ethnically defined. Now foreigners belong to those joined to Yahweh (56:3). Conversely, within those who are God's adversaries, Edom, the brother of $J a c o b$, must be named above all others as standing unrepentant outside the circle of the just. For the author of Third Isaiah, the

\footnotetext{
${ }^{85}$ Childs, Isaiah, 519.

${ }^{86}$ Childs, Isaiah, 519.

${ }^{87}$ Smith, Rhetoric and Redaction, 38-39.

${ }^{88}$ Westermann, Isaiah 40-66, 286, 238; Smith, Rhetoric and Redaction, 38-39.

${ }^{89}$ Op.cit. Smith, Rhetoric and Redaction, 39. On the connection of Edom with nations see the intertextual emphasis Seitz gives to Isaiah 34-where Edom's defeat is an indication of the coming vindication of Yahweh (Seitz, "Isaiah 40-66," 519).

${ }^{90}$ Childs advances Beuken's argument (Childs, Isaiah, 518).
} 
division between the righteous and the unjust is not a lingering cultural prejudice, but is an ontological portrayal of the paradoxical nature of evil with which finally he concludes his book $(66: 24){ }^{91}$

Thus, the vindication of God in Isaiah 63 is carried out on behalf of the Holy People highlighted in 62:12 who have been defined previously as those righteous ones / servants who have responded in penitence to the call of God by means of the Servant. Beuken observes the one drama taking place in 56:1-63:6 as the theme of the servants, marked out by the key terms "righteous" and "seed/offspring", rising from oppression and $\sin$ to become the righteous offspring of the Servant whether they are foreigner or national. $^{92}$

\section{3.c. The Servants in Isaiah 63:7-66:22}

\section{3.c.1. Isaiah 63:7-64:12}

Form critically, this section of the prophetic literature bears the marks of a communal lament or complaint. ${ }^{93}$ Contextually, this literary unit flows from the preceding section. ${ }^{94}$ Faithful Israel, having confessed its $\sin$ in the midst of an unrighteous people (59:1ff.), is assured of the coming salvation of their Redeemer (60-62). Yet, before this activity can take place, God's terrible judgment must fall (63:1-6). In 63:7ff., the voice of the faithful remnant, defined as the "servants" and "tribes of your heritage" (63:17-18), raise their voice in lament to their God as they rehearse "God's past mercies, confess their sins, call for divine intervention, and plea for aid in need." 95 Beuken states,

In this prayer there is no question of that salvation to come, but of the present misery of oppression, sin and obscuring of God, as it is said: 'Return for the sake of thy servants, the tribes of thy

\footnotetext{
${ }^{91}$ Childs, Isaiah, 518. See also chapter 2 , n. 41.

92 Beuken, "The Main Theme," 75.

${ }^{93}$ Seitz warns against a too simplistic designation of "lament" in this rich text. Psalms of recital (e.g. Ps 44; 66; 78; 105-107) also resemble this text (Seitz, "Isaiah 40-66," 525). Lament or complaint do not do justice to the overall form-critical "feel" of the text. Childs, Isaiah, 522-523; Seitz, "Isaiah 4066," 524; Smith, Rhetoric and Redaction, 44; Beuken, "The Main Theme," 75. Redactional questions pertaining to this text have been plenty. Smith and Westermann note chaps. 60-62 as the answer to the communal lament in 63:7-64:12 (Smith, Rhetoric and Redaction, 44-46; Westerman, Isaiah 40-66, $300)$. Seitz, on the other hand, affirms the canonical placement of the literary unit as flowing from the preceding chapters to the subsequent vision in 65 and 66 of the new heavens and new earth. The response to the lament is not found in 60-63 but in 65 (Seitz, "Isaiah 40-66," 525). The most complex issues pertaining to this text are the text-critical problems. See Childs, Isaiah, 521, 523-526.

${ }^{94}$ Smith shows various connections between Isa 63:7-64:14 and 60:1-63:6. Smith, Rhetoric and Redaction, 44-46.

${ }^{95}$ Childs, Isaiah, 522.
} 
heritage. Since a little while they have lodged thy holy people, our adversaries have trampled the sanctuary' (63.17-18). ${ }^{96}$

It is in this passage that the term "servants" emerges again as a forceful concept that will remain visible until the end of the book. ${ }^{97}$

The Exodus tradition is recalled in 63:8-14 coupled with the presence of the covenant formula in $63: 8$ (cf. Deut $26: 12 ; 29: 13$ ). The stipulation of the covenant is that God's son "will not act falsely" with the reciprocated assurance of God's continued acting as their savior. God's presence is described as the saving act of love for his people in days of old. ${ }^{98}$ However, the people have not acted in faithfulness but have rebelled resulting in their status as the enemies of God (63:10). Seitz observes the typological-figural representation taking place in this section. ${ }^{99}$ The language resembles that of Isaiah 1 and the Exodus tradition. Thus, "We move from wilderness rebellion, to rebellion of former Isaiah days, to present rebellion." ${ }^{100}$ It is within this context of a rebellious people that the servants raise their voice to Yahweh as Father-a description of God rarely observed in the OT. ${ }^{101}$

The hardness of heart, like that of Pharaoh, is predicated to the people of God, and the cry of the servants is for Yahweh to return for the sake of the servants who are living in a time when the sanctuary is desecrated. ${ }^{102}$ The mission of the Servant (Isa 49:6) is intertextually present. It is the Servant's task to "raise up the tribes of Jacob," and here the servants are described as that tribe. Yet tension is present. Those faithfully following the Servant, the servants, recognize the present reality of suffering and the unfulfilled nature of the promises to the Servant. Beuken summarizes, "We determine that TI [Trito-Isaiah] cannot tally the present misery

\footnotetext{
${ }^{96}$ Beuken, "The Main Theme," 75.

${ }^{97}$ The theme of the servants is a central theme of Isa 59:7-63:6 as has been shown, but the actual term "servants" has not been visible.

${ }^{98}$ There is a difficult textual question at 63:9. There is a Kethib/Qere present with the $מ$. The Qere reading is as follows "in all their troubles, he was troubled." The Kethib (followed by the LXX and the NRSV) coupled with a different pointing of (MT: affliction; LXX: messenger) reads "it was no messenger or angel, but his face (presence) that saved them" (Childs, Isaiah, 523). Childs follows the MT, though finding the LXX reading attractive. For Childs, Exod 33:12-23 parallels this passage. God was grieved by the golden calf incident yet he extends his presence to them in spite of their faithlessness. Seitz, on the other hand, affirms the essential contrast between God's presence and a potential go-between. Seitz, "Isaiah 40-66," 526.

${ }_{99}^{9}$ Seitz, "Isaiah 40-66," 527.

${ }^{100}$ Seitz, "Isaiah 40-66," 527.

${ }^{101}$ Childs, Isaiah, 524; Seitz, "Isaiah 40-66," 527; Westermann, Isaiah 40-66, 393. The rare use of Father in the OT may be linked to its mythical connotations in the ANE. God is Father in this passage in light of Abraham's absence. See Motyer, The Prophecy of Isaiah, 517; Seitz, "Isaiah 40-66," 527528.

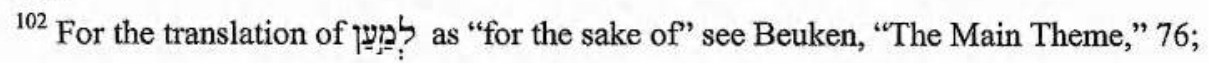


either with the mission of the Servant and YHWH's promise to him or with the status of the servants. In the last main section this dilemma will receive a solution." ${ }^{\prime 103}$ It is within Isaiah 65 and 66 that the theme of the servants of the Servant comes to its climax coupled with the ultimate eschatological presentation of the New Heavens and the New Earth as the completion of God's promise to the Servant and the servants.

\section{3.c.2. The Servants in Isaiah 65-66}

Much attention has been given to these two chapters. Recent trends in Isaianic scholarship have emphasized the unity of 65-66 along side its particular canonical placement as a conclusion to the book as a whole. ${ }^{104}$ Regarding the servants, Isaiah 65 is a key chapter in the development of the servants theme in Isaiah $54-66 .{ }^{105}$ The term "servants" occurs in Isaiah 65 six times $(65: 8,9,13[3 x], 15)$ along side the various thematic terminology related to the servants, e.g. blessing or bless $(65: 8,16,23)$, seed $(65: 9,23)$, my people $(65: 10,18,19,22)$. Within the proximate contextual placement of Isaiah 65-66, these chapters stand as the answer to the lament of the servants in 63:7-64:12. As the conclusion to the movement of the servants theme in Isaiah 56ff, the righteous seed, that is the servants of the Servant, are rewarded and vindicated in spite of the current circumstances of suffering. ${ }^{106}$

Isa 65:20-23 identifies the servants as an oppressed group suffering in the current age. In this chapter (e.g. 65:1-7, 8-16, 17-25) God is making a distinction between the righteous servants and the wicked. ${ }^{107}$ Within the narrative nature of this text, God is addressing the wicked, the oppressors of the servants, and his address to the wicked is the answer to the cry of the servants in the preceding chapters. The

\footnotetext{
${ }^{103}$ Beuken, "The Main Theme," 76. The prayer of the servants continues in Isaiah 64 as they continue to confess their sins and admit their dependence on the Potter, the Lord their Father.

${ }^{104}$ Marvin Sweeney, "Prophetic Exegesis in Isaiah 65-66," in Writing and Reading the Scroll of Isaiah, 455-474; Beuken, "Isaiah LXV-LXVI;" New Visions of Isaiah, ed. by R.F. Melugin and M.A. Sweeney; L.J. Leibreich, "The Compilation of the Book of Isaiah," JQR 46 (1955-56) 276-277 and JQR 47 (1956-57), 126-127; R.A. Smith, Rhetoric and Redaction, 128-172; O.H. Steck, Studien zu Tritojesaja, BZAW 203 (Berlin: Walter de Gruyter, 1991); Childs, Isaiah, 532-534; Seitz, "Isaiah 4066 ," 538-542. Childs shows signs of hesitation with Beuken's redactional reading. For Childs, the literary effect, e.g. the canonical force of the books final shaping, is more important is more important than deciphering the redactional layers (Childs, Isaiah, 533). Again, this project fits within Childs' vision of emphasizing the final form, the form Paul most definitely would have read and re-read. ${ }^{105}$ Beuken, "The Main Theme," 76.

${ }^{106}$ Beuken, "The Main Theme," 76-77; Seitz, "Isaiah 40-66," 539.

${ }^{107}$ Seitz, "Isaiah 40-66," 542. Again, the hesitation at delimiting certain redactional units in Isaiah 65 is observed. For a fuller treatment of the possible redactional units, see Smith, Rhetoric and Redaction; Beuken, "Isaiah LXV-LXVI." Childs and Seitz both helpfully summarize these various approaches. Each conclude, however, that an emphasis on the final form is most literarily and theologically significant (Childs, Isaiah, 534; Seitz, "Isaiah 40-66," 538-542).
} 
wicked are described as those who have not responded to the call found in Isa 55:6 (65:1-2, "seek the Lord while he may be found." Ironically, the wicked are involved in a form of worship that has resulted in their castigation of the servants. The wicked define themselves as "sacred" whereas the servants are placed in a lower religious class (65:5). Seitz notes that the description given by God of the worship of the wicked and of the servants $(66: 2,5)$ portrays the servants, in distinction from the wicked, as those who "tremble" at the word of God. ${ }^{108}$ The wicked are involved in false worship whereas the servants are faithfully following their God. ${ }^{109}$ Those who have truly sought the Lord (Isa 55:6) are the servants, and their salvation is being eschatologically realized in this passage.

The blessing announced to the servants begins in 65:8. Though they are like a cluster of grapes whose juice appears to be almost gone, the divine vintner intervenes and spares the grapes for their blessing (65:8). The following verse promises offspring (זרע) and these offspring are his chosen ones (בחירי), his servants (עבד). ${ }^{110}$ Again, the intertextual referent to Isa 55:6 is observed as the servants are described as those who have sought after the Lord, responding obediently to his call, whereas the wicked are continuing to seek their own way as they forsake the Lord $(65: 11) .^{111}$ The servants are assured that they will inherit the holy mountain, a reference to Yahweh's promise given in Isa $56: 7 .^{112}$

What comes to the forefront in this "blessing" passage is God's new creative activity centered on the establishing of his servants. ${ }^{113}$ They are set in opposition to the wicked who receive the covenant curses while the covenant blessings fall on the faithful, the servants. The actuality of this vindication is found in $65: 13-15$ as the blessings of the servants are set in opposition to the apostates of Israel. These contrasts are as follows: to eat and to be hunger, to drink and to be thirsty, to rejoice and to be put to shame, to sing and to cry, to leave one's name as a curse and to be called a different name by Yahweh. ${ }^{114}$ Beuken shows how these word pairs find their

\footnotetext{
${ }^{108}$ Seitz, "Isaiah 40-66," 542.

${ }^{109}$ The exact nature of this worship is not described (Seitz, "Isaiah 40-66," 543).

${ }^{110}$ On the servants as the chosen ones cf. Isa 42:1; 45:4 (Beuken, "The Main Theme," 78).

111 Seitz, "Isaiah 40-66," 543.

112 Beuken, "The Main Theme." 78.

${ }^{113}$ Beuken "The Main Theme," 77-78.

${ }^{114}$ Beuken, "The Main Theme," 78.
} 
source in the "literary genre of blessing and cursing."115 Beuken also stresses that these themes are found within Isaiah 56-66 itself (56:9ff; 58:7, 10; 61:17; 62:8f., $65: 21 f ; 66: 5,10) .^{116}$

The new name bestowed on the servants is not given an explicit reference.

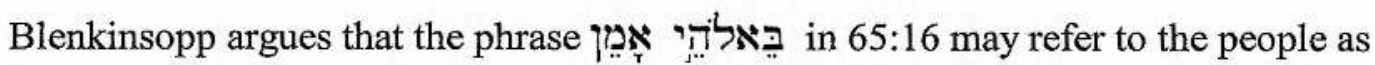
the "Amen people," that is the people who have said Yes to God. ${ }^{117}$ Beuken affirms this general direction as well. ${ }^{118}$ With this said, however, the exact referent of the name is not revealed in the text. The literary emphasis is on the "eschatological reversal" taking place in God's program of redemption. ${ }^{119}$ The servants have suffered in the present age on account of their faithful response to the call of obedience given by the Servant (Isa 50:10). Now in the eschatological day of vindication, the roles are reversed. The wicked receive God's judgment and the righteous servants are vindicated. Seitz summarizes, "To turn away from the lavish forgiveness proffered by God and brought about by the sacrifice of the servant is a worse offense than to stand under Isaiah's 'former thing' judgment...God called and spoke anew, but some refused to listen and answer, choosing instead a way of death." 120 The servants, on the other hand, have responded to God's call. Their response results in life, in new creation.

The presentation of the servants' vindication is revealed in $65: 17-25$ as complete and full, "the former things are forgotten and over." ${ }^{121}$ It is necessary to keep before the interpreter the narrative flow that has led to the current literary unit, a narrative flow that has centered on the offspring of the Servant, the servants. Hanson has made much of apocalyptic categories in his reading of the new creation text. ${ }^{122}$ What needs to be maintained, however, is that the presentation of a new heavens and a new earth, though reminiscent of later apocalyptic categories, is not "an apocalyptic

\footnotetext{
${ }^{115}$ Beuken, "The Main Theme, 79. Cf. Deut 28:1-26, 48; 2 Sam 24:13; Ezek 4:17; Amos 8:11. See also $1 \mathrm{Kgs} \mathrm{18:2;} \mathrm{Isa} \mathrm{1:29,} \mathrm{5:13,} \mathrm{8:21,} \mathrm{37:27;} \mathrm{Jer} \mathrm{5:12,} \mathrm{6:15,} \mathrm{42:14;} \mathrm{Ezek} \mathrm{19:13;} \mathrm{Mic} \mathrm{7:16;} \mathrm{Pss} \mathrm{34:11,} \mathrm{69:22;}$ Lam 4:4; 5:10; Neh 9:20.

${ }^{116}$ Beuken, "The Main Theme, 79.

${ }^{117}$ Blenkinsopp, "The Servants of the Lord," 396.

${ }^{118}$ Beuken, "The Main Theme," 79. Childs reads the passage as "they will swear by the God of Amen" or "the God of Truth". Childs, Isaiah, 537. Both Blenkinsopp and Motyer make mention of 2 Cor 1:20 in their discussion of this text, all the promises of God are "yes" in Jesus Christ (Blenkinsopp, "The Servants of the Lord," 396; Motyer, The Prophecy of Isaiah, 529).

${ }^{119}$ Blenkinsopp, "The Servants of the Lord," 396.

${ }^{120}$ Seitz, "Isaiah 40-66," 544.

${ }^{121}$ Seitz, "Isaiah 40-66," 544.

${ }^{122}$ P.D. Hanson, The Dawn of Apocalyptic (Philadelphia: Westminster/John Knox, 1975), 134-186. See Childs' comments in Childs, Isaiah, 537-538.
} 
flight into an imaginative world of fantasy, but the fulfillment of God's will taking shape throughout the entire book of Isaiah." ${ }^{, 23}$ In other words, an apocalyptic escapism is not present within the current text. What is present is the eschatological hope of God's faithful servants depicted as fulfilled, and fulfilled in a way that can be described in no other terms than "a new heavens and a new earth." Seitz comments, "In order for the former things to be put away for good, God must begin all over again.",124

The technical term for God's act of creation is ברא, a term that designates God's creating activity which has no human analogy. ${ }^{125}$ Von Rad's article of 1936 , "The Theological Problem of the Old Testament Doctrine of Creation," emphasized the subordinate role creation played to Israel's hope in salvation history. ${ }^{126}$ Harner, on the other hand, has argued that creation does not play a subordinate role to redemption per se; instead, for the prophets creation itself is an indicator of God's new redemptive, creative activity in Israel's history. ${ }^{127}$ In other words, the original creation account has been eschatologically re-read by the prophets as an indicator of the hope of God's coming redemption in history, and no other prophetic text makes use of creation language more than Isaiah $40-66{ }^{128}$ This new creative activity of God is, contextually, aimed at the restoration of the faithful servants who have experienced oppression in their current circumstances yet are to be vindicated by God in the new eschatological era, the new heavens and the new earth.

The description of God's vindication of the servants, the new creative activity of God, is portrayed in $65: 18-25 .{ }^{129}$ In this new eschatological day, a great reversal of

\footnotetext{
${ }^{123}$ Childs, Isaiah, 538.

${ }^{124}$ Seitz, "Isaiah 40-66," 544. On the term "garden" in Isaiah 40-66 as an eschatological theme referring to a return to Eden, see William P. Brown, Ethos of the Cosmos (Grand Rapids: Eerdmans, 1999), 229-269.

${ }^{125}$ Childs, Biblical Theology, 111.

${ }^{126}$ Gerhard von Rad, "The Theological Problem of the Old Testament Doctrine of Creation," in The Problem of the Hexateuch and Other Essays (Edinburgh: Oliver \& Boyd, 1966), 131-143. For the placement of von Rad's argument in light of the critique of others (e.g. Anderson, Westermann), see Childs, Biblical Theology, 109-110. Stuhlmueller's extensive work on creation in Isaiah 40-66 follows von Rad on this score (Carol Stuhlmueller, Creative Redemption in Deutero-Isaiah [Rome: Biblical Institute Press, 1970], 5). For Stuhlmueller, the descriptive definition of creation in Isaiah 40-66 is as follows: "An exceptionally wondrous redemptive act of Yahweh, bringing to Israel a new national existence and a new prosperity of unprecedented scope, with 'creative' repercussions upon all the elements of Israel's existence, even upon the cosmos" (Stuhlmueller, Creative Redemption, 9).

${ }^{127}$ P. B. Harner, "Creation Faith in Deutero-Isaiah," VT 17 (1967), 298-306.

${ }^{128}$ Childs, Biblical Theology, 114; Brown, The Ethos of the Cosmos, 264; B.W. Anderson, From Creation to New Creation, 37.

${ }^{129}$ Childs emphasizes that "the new heavens and the new earth is portrayed always in relations to God's faithful people..." (Childs, Isaiah, 538).
} 
fortunes will take place. Those who have experienced oppression and suffering will "be glad and rejoice forever" (65:18). Their weeping and sorrow will be heard no more $(65: 19)$. The theme of the servants comes to the fore again in $65: 23$. The intertextual presence of 61:9 is apparent as those who are the oppressed will be recognized as "the offspring which Yahweh has blessed." Beuken states, "Thus 65.23 completes the identification of the oppressed with the servants of YHWH."130 The new creative activity of God is the completion of the promise made to the Servant regarding his offspring (53:10). With language reminiscent of the new covenant imagery of Jeremiah $(65: 24)$, the fission between the divine and humankind has been removed. "In the ruptured existence after disobedience, God must call to humankind, who is hiding. And, mortals must now call on God, in a different dispensation of communication, fraught with sin and anguish and avoidance and rebellion. But in the age described in 65:17-25, all that is confused and wreaked in divine-human exchange is gone." ${ }^{\prime 31}$ The people promised to the Servant as his offspring are presented as transformed and renewed in Isaiah 65. They have remained faithful in the current age of suffering and their vindication is promised (61:9) and fulfilled (65:17-25).

The theme of the servants is found in Isaiah 66 as well. Though scholars have given much attention to the redactional layers of Isaiah 66 , the attempt presented in this project is to hear the book of Isaiah in its final form. ${ }^{132}$ Childs has argued that the literary effect of Isaiah 66 is to bring to conclusion the whole of the book of Isaiah. ${ }^{133}$ Also, there are "language links" between chapter 65 and 66 that should intimate a close reading between the two: "heaven and earth; verbs for slaughtering, sacrifice, and offering; the centrality of joy and rejoicing for the servants; calling and speaking (not responded to); Zion's new birthing; and fire judgment." ${ }^{\text {134 }}$ Our attention, however, will remain fixed on the servants.

Again, the description before the reader is that of the opposition between the servants and the apostates who worship in idolatry. God's affections are given to

\footnotetext{
${ }^{130}$ Beuken, "The Main Theme," 80.

${ }^{131}$ Seitz, "Isaiah 40-66," 545 . The intertextual reference to Isa 11:6-9 is observed in 65:25. The day promised in Isaiah 11 is eschatologically realized in this passage. See Gene M. Tucker, "The Peaceable Kingdom and the Covenant with the Wild Animals" in God Who Creates ed. by W.P. Brown and D. McBride Jr. (Grand Rapids: Eerdmans, 2000), 216-219; Richard Bauckham, "Jesus and the Wild Animals," in Jesus of Nazareth Lord and Christ ed. by J.B. Green and M. Turner (Grand Rapids: Eerdmans, 1994), 3-21.

${ }_{132}$ On redactional layering, see Smith, Rhetoric and Redaction, 153ff; Beuken, "The Main Theme," 82.

${ }^{133}$ Childs, Isaiah, 539; Seitz, "Isaiah 40-66," 545.

${ }^{134}$ Seitz, "Isaiah 40-66," 545.
} 
those who are humble and contrite in spirit, the ones who tremble at his word (66:2, 5). ${ }^{135}$ Zion brings forth her children and receives comfort from the Lord (Isa 66:7-13; cf. Isa 40:1-5). The contrasts between the fate of the servants and of the wicked are again rehearsed in 66:14. Beuken states, "Thus the theology of Zion in the second half of BI [book of Isaiah] reaches its climax here. YHWH, who lets Jerusalem produce new offspring in a miraculous way, also enables it to suckle the offspring. The city is the habitat of consolation for the progeny promised to the Servant."136 The book of Isaiah ends with an encapsulating description of all that has been promised in Isaiah 40-66. Isaiah 66:17-24 rehearses the gathering of the nations for the seeing of God's glory (Isa 41:5), the survivors are sent to the nations as a witness, foreigners are chosen as priests for the Lord (56:6ff), and the fate of those who rebel against God is finalized. ${ }^{137}$ Commenting on Isa 66:17-24, Childs concludes, "The radical formulation of 65:17-18 is repeated, but now in such a way as to provide an interpretation of the earlier promises as a part of the one eschatological goal: the creation of a new heaven and new earth." ${ }^{138}$ This new heavens and new earth is composed of those faithful followers of the Servant who have remained loyal to the will and ways of God, whether they be foreigner or national. In the midst of the present tension of suffering and eschatological longing, Isa 66:12 reminds the reader that "the hand of the Lord is with his servants." 139 How then are the servants of the Servant characterized in their narrative identity?

\section{3.d. The Servants' Narrative Identity}

The question of the narrative identity of the servants is raised at this point-as the question of the narrative identity of the Servant was rehearsed in the last chapterthat is, how are the servants' actions and identity portrayed within the narrative. What becomes progressively noticeable in the movement from the Servant to the servants is the linkage of the identity of the servants with the Servant. As has been observed, the servants are the promised offspring of the Servant (53:10) who have responded in obedience and faithfulness to the call of the Servant (50:10). Also the overlap between the servants and the heralds of the good news becomes more apparent in Isaiah 61.

\footnotetext{
${ }^{135}$ Blenkinsopp, "The Servants of the Lord," 398-401.

${ }^{136}$ Beuken, "The Main Theme," 83 . The promise made by the Servant in 48:18 is here presented as fulfilled for the benefit of the servants $(65: 12)$, "I will extend peace to her like a river."

${ }_{137}$ Childs, Isaiah, 542; Seitz, "Isaiah 40-66," 547-550; see also Seitz, Figured Out, 156.

${ }^{138}$ Childs, Isaiah, 542.
} 
Therefore, the servants narrative identity is as follows: they are heralds of the message of the Servant, sufferers in righteousness, waiting in the eschatological tension.

Isa 52:7 climaxes with the heralds of the good news announcing the coming reign of God. Contextually, this flows into the fourth servant song. Seitz has argued that the message of Isaiah 53-presented in the first person plural of 53:1 -is delivered by the servant followers of the Servant. The connection between the heralded message of good news and the activity of the Servant is textually demonstrated in the movement of 52:7 to 52:13-53:12, e.g. the good news is linked with the Servant's work. Also, the heralds of the message become more readily apparent in Isaiah 61, where the Servant and the heralds converge in the continuing role of the servants. Thus, the identity of the servants is revealed as those who continue the work of the Servant by announcing the good new of his activity on behalf of God's people. ${ }^{140}$ Again, Seitz states, "They [the servants] saw the deeper significance in his [the Servant's] death than the others saw in his death and the fulfillment of God's earlier promises... This radical and bracing proclamation the servants judge to be the continuation of the work of the servant, whose death did not bring defeat but the possibility of a new beginning." 141 The inner logic of the movement of Isaiah 40-55 to Isaiah 56-66 suggests that the Servant's mission and work is continued by the servant followers, not by replacing the Servant, but by following in faithfulness the call of the Servant (Isa 50:10ff) and by recognizing retrospectively the significance of the death of the Servant for both Israel and the nations (Isa 52:13-53:12).

The servants' obedient following of the Servant leads to their own suffering in righteousness (Isa 57:1). They face opposition in the current age and are often set in opposition to the wicked. Beuken states, "Now the victims of that sinful generation have a likeness to the Servant. They undergo his destiny: they as well as he are 'righteous' (53:11; 57:1) and yet they experience suffering." ${ }^{\text {"142 }}$ Suffering becomes integral to the narrative identity of the servants. Their continuing of the message of the Servant is conjoined with their suffering in the present age. They, like the Servant,

\footnotetext{
${ }^{139}$ Jeppesen, "From You My Servant," 128-129.

${ }^{140}$ See Childs, Isaiah, 404-405; Robert W. Fisher, "The Heralds of Good News in Second Isaiah," in Rhetorical Criticism: Essays in Honor of James Muilenburg ed. by J.J. Jackson and M. Kessler (Pittsburg: The Pickwick Press, 1974).

${ }_{141}$ Seitz, "Isaiah 40-66," 424.

142 Beuken, "The Main Theme," 69.
} 
continue in righteousness though it leads to suffering, yet, they place their hope in the future vindication of God.

This leads to the final observation of the servant's narrative identity. The servants are caught between the two ages. They live in an eschatological tension between current suffering (Isa 63:6-64:12) and the future hope of vindication and restoration (65:17). The servants act and live in the midst of suffering with the hope of the coming day. In Isa 63:6-64:12 these righteous ones are presented as sufferers, yet God declares their coming restoration and joy in Isaiah 65 . The servants will eat while the wicked hunger; they will drink while the apostates thirst. The servants recognize that though they suffer, "the hand of the Lord is with them" (Isa 66:14).

In conclusion, the servants are revealed as the continuing effect of the activity of the Servant. They are distinct from the Servant. As Seitz states, "The servants are to the servant as Joshua and Caleb were to Moses." ${ }^{\text {143 }}$ Blenkinsopp similarly observes, "If moreover, the titles (Servant, servants) are the same, it is because the disciples embody the form and exemplify the consequences of the prophetic founder's ministry."144 Thus, the servants' work and mission are intricately connected to that of the Servant, but in a subordinate role, a role that finds its distinctiveness in its continuation of the work of the Servant. Their roles overlap-as is seen in Isaiah 61but the one continues the work of the other and does not share in the same status- the Servant is raised and exalted in Isa 52:13. The servants are the offspring of the Servant (53:10), the promised seed resulting from the Servant's death, who suffer in righteousness as did the Servant in their continuing embodiment of the Servant's faithfulness. In the midst of this continuing faithfulness they await the coming day of vindication in God's eschatological time-table. ${ }^{145}$

\section{Paul as a Servant of the Servant}

The preceding descriptive account of the servants of Isaiah 54-66 shows the movement taking place within the larger structure of Isaiah 40-66 from the Servant to the servants. The vocation of Israel passed onto the shoulders of an individual (Isa 49:1-6) who embodies Israel's role both to herself and to the nations. This vocation involved the Servant's innocent and righteous suffering on the behalf of others

\footnotetext{
143 Seitz, "Isaiah 40-66," 424.

${ }^{144}$ Blenkinsopp, "The Servants of Yahweh," 411.

${ }^{145}$ See also Seitz, Figured Out, 115,156.
} 
resulting in the death of the Servant as a vicarious act. The Servant's work and actions produce a righteous offspring who inherit his suffering in the present age. These servants of the Servant recognize retrospectively the significance of the Servant's death as they herald the message (Isaiah 53) in the interim period of awaiting vindication.

This same type of dramatic movement takes place within 2 Cor 5:14-6:10. The apostle Paul recognizes retrospectively the significance of the work of Christ ( 2 Cor 5:16-Paul's new epistemology) and Paul's particular vocation is in the heralding of that message. Paul's recognition of Christ's work as sufferer on behalf of others leads the apostle into a similar vocation of suffering while waiting. As Lambrecht states, "Paul thus sees his suffering in connection with the death of Christ. To be united with Christ means that the minister will have to suffer as Christ did. Through all his trials he really participates in the suffering of Christ." 146 The movement of Isaiah 40-66 in its final canonical shape is a figural representation of the movement taking place in our particular passage of study. Thus, our identification of Paul in the redemptive drama of Isaiah 40-66 is that of servant of the Servant.

As in the previous chapter, our attention will turn to the various conceptual overlapping between the servants and Paul in 2 Cor 5:14-6:10. Those areas of overlap that have been especially noted are as follows: 1) Paul as herald; 2) Paul as sufferer; 3) Paul as sufferer in righteousness; 4) Paul in the eschatological tension.

\section{4.a. Paul as Diakonoi}

Before proceeding to the conceptual overlap between the narrative movements of Isaiah and our passage of study, brief attention will be given to Paul's use of the term

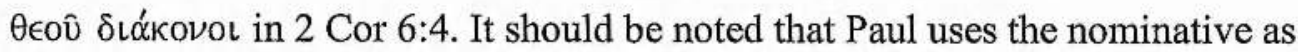
opposed to the accusative in this verse. Thus, Paul is not seeking to prove he is a servant of God but is demonstrating that as a servant of God he is commending himself in a way that a servant of God should. ${ }^{147}$ This leads into Paul's list of hardships with the implication that this is how a servant of God commends himself.

\footnotetext{
${ }^{146}$ Lambrecht, Second Corinthians, 114.

${ }^{147}$ See Furnish, II Corinthias, 343; Martin, 2 Corinthians, 172; Barrett, A Commentary on the Second Epistle to the Corinthians, 185.
} 


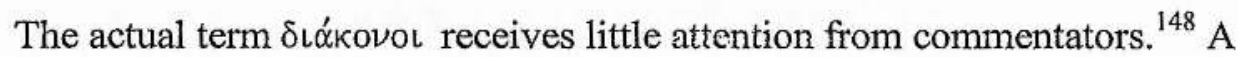
detailed discussion of the term has been given by John N. Collins. ${ }^{149}$ Typically,

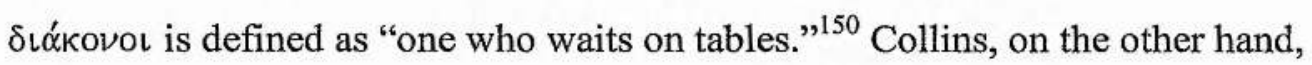
challenges this definition as the "basic meaning." 151 The root idea in Collins reading

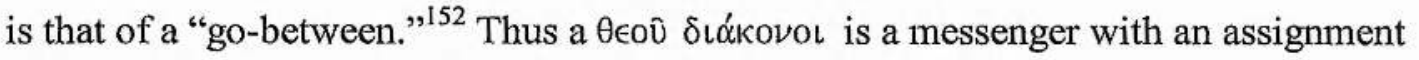
from God integrally related to mission on behalf of others. ${ }^{153}$ The lexeme $\delta$ เókovoเ serves as an indicator of both passive and active meanings. Paul describes himself as a

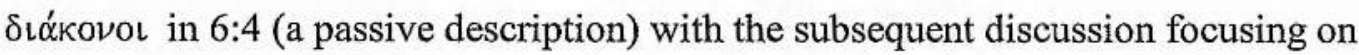
Paul's exercising of his office (an active description). ${ }^{154}$

Within the literary unit of 2 Cor 2:14-7:1, Paul uses $\delta$ เókovol as an indicator of his role in 2 Cor $3: 6 ; 5: 18 ; 6: 4$, particularly related to his role in the new covenant. ${ }^{155}$

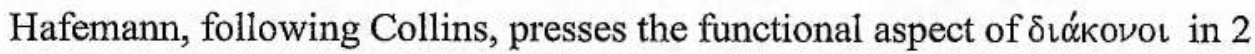
Corinthians 3. The term does not designate a particular office per se, but stresses an act of mediation and representation. ${ }^{156}$ Hafemann states that Paul does not use

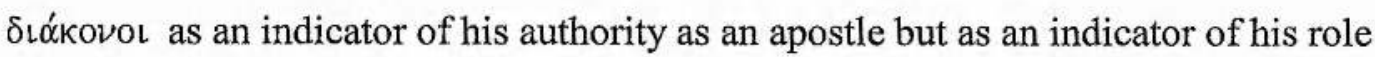
and function. ${ }^{157}$ Though Hafemann's previous statement may be overstated, Hafemann is correct to conclude, "In referring to himself as a "servant of the new covenant,' Paul emphasizes that he has been called to perform those activities that are

\footnotetext{
${ }^{148}$ R. Bieringer, "Paul's Understanding of Diakonia in 2 Corinthians 5,18 " in Studies on 2 Corinthians by R. Bieringer and J. Lambrecht (Leuven: Leuven University Press, 1994), 421.

149 John J. Collins, Diakonia: Re-interpreting the Ancient Sources (Oxford: Oxford University Press, 1990).

${ }^{150}$ Exegetical Dictionary of the New Testament, Vol 1, ed. by H. Balz and G. Schneider (Grand Rapids: Eerdman s, 1990), 302.

${ }^{151}$ Collins, Diakonia, 194. Beiringer traces the arguments surrounding this term. His article is a most helpful summary and analysis of the issues. Beiringer, "Paul's Understanding of Diakonia." Hafemann follows Collins on this score as well, Hafemann, Paul, Moses, 111.

152 Collins, Diakonia, 194.

${ }^{153}$ Collins, Diakonia, 195; Anthony C. Thiselton, The First Epistle to the Corinthias, NIGNTC (Grand Rapids: Eerdmans, 2000), 300.

${ }^{154}$ Beiringer, "Paul's Understanding of Diakonia," 426.

${ }^{155}$ See Hafemann, Paul, Moses, 110-119; Ellen Juhl Christiansen, The Covenant in Judaism and Paul: A Study of Ritual Boundaries as Identity Markers (Leiden: Brill, 1995), 253-259; Lane, "Covenant: Key to Paul's Conflict."

${ }_{156}$ Hafemann, Paul, Moses, 112.

${ }^{157}$ Hafemann, Paul, Moses, 112-113. Hafemann gives detailed discussion in the footnotes as to why he does not follow Collins on this score. "The designation 'servant' is therefore a more general term which can be used to describe those engaged in a particular work of service ( $\delta\llcorner\alpha \kappa o v i \alpha)$." Hafemann, Paul, Moses, 112. Collins, Diakonia, 197ff. Though the semantic emphasis of otókovot is that of function or role, to press a strong dichotomy between function and authority as apostle seems over stated. In 2 Cor 6:4 Paul defines himself as a "servant of God" and then commends himself in a way that is fitting for a servant of God. The apostolic authority Paul is defending is one that inverts the priorities of the Corinthians and emphasizes that suffering is a part of that calling and function. See Schütz, Paul and Apostolic Authority, 178-179.
} 
in accord with the new covenant ministry of the Spirit as already experienced by the Corinthians as a result of Paul's apostolic ministry of suffering and proclamation of the gospel."158 Paul's designation of himself as $\delta$ เ $\alpha$ kovo in 2 Corinthians 3, 5 and 6 centers on Paul's particular role as proclaimer and sufferer subordinate to Christ's own person and work. ${ }^{159}$

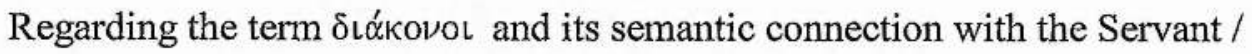
servants of Isaiah 40-66, great care must be taken lest the argument be pushed too far. Of particular interest is the use of $\delta\llcorner\alpha \kappa o \nu \epsilon \epsilon$ in its infinitive form in Mark 10:45. The service rendered in Mark 10:45 by Jesus has often been noted as an allusion to the work of the Servant. ${ }^{160}$ This has been recently challenged by the likes of Hooker and Stuhlmacher. Hooker bases her argument on the absence of any use of the term $\delta\llcorner\alpha \kappa o \nu \in \omega$ in the LXX. It should be stated, however, that עבד has a certain amount of semantic fluidity in its translation into Greek. $\Delta$ ov̂ Servant in Isaiah 40-55 (Isa 49:3) alongside the preferred term $\pi \alpha i \varsigma .{ }^{161}$ Hooker has also emphasized the Servant's service in Isaiah is directed toward God whereas Jesus' service is directed toward others. ${ }^{162}$ Stuhlmacher, on the other hand, places Mk 10:45 in the context of the Son of Man tradition in Daniel 7 and I Enoch. ${ }^{163}$

Watts has helpfully pushed this discussion forward. First, the distinction between rendering service to God and rendering service to others--Hooker's pitting of Isaiah's Servant against Jesus - is "more apparent than real."164 Though the Servant is described in Isaiah primarily on the basis of his relationship to Yahweh-the nature of the issue in Isaiah 40-55 - this does not imply that the Servant did not render service for others, e.g. Isaiah $53 .{ }^{165}$ Secondly, the semantic distinction between

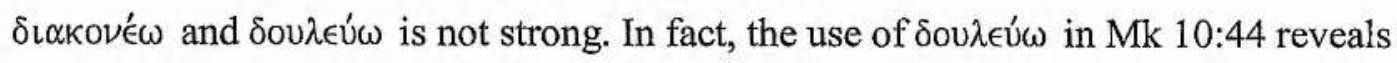

\footnotetext{
${ }^{158}$ Hafemann, Paul, Moses, 114. See Christiansen's emphasis on "new" as "eschatological renewal rather than temporal replacement." Christiansen, The Covenant, 259. This reading of the "new" language in 2 Corinthians 2:14-7:1 coheres with the reading of this project. Paul understands the eschatological era pointed to in the OT, especially by Isaiah, as having arrived.

${ }^{159}$ See, The Exegetical Dictionary of the New Testament I, 303.

${ }^{160}$ Watts, Isaiah's New Exodus, 271.

${ }^{161}$ Hooker, Servant, 74. Commenting on Phil 2, Hooker states, "We have already noted that the LXX

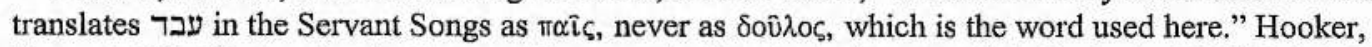
Servant, 120. Hooker is mistaken on this score. $\Delta$ oûdoఢ is the lexeme of choice in the LXX Isaiah 49:3. ${ }^{162}$ Hooker, Servant, 74f.; Watts, Isaiah's New Exodus, 271.

${ }^{163}$ Cf. Watts, Isaiah's New Exodus, 271. On the Daniel 7 theme and Isaiah 53, Watts concludes that these two are not in opposition to each other. Watts identification of the Servant of Isaiah theme does not discount other themes as well. Watts, Isaiah's New Exodus, 285.

${ }^{164}$ Watts, Isaiah's New Exodus, 272.

${ }^{165}$ Watts, Isaiah's New Exodus, 272-273.
} 


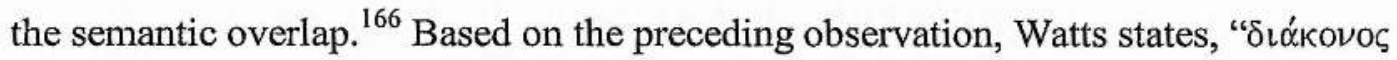

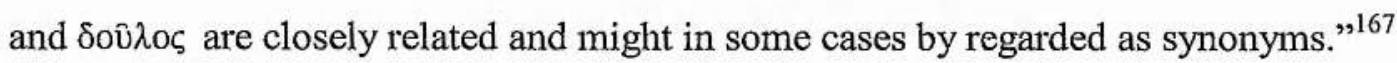

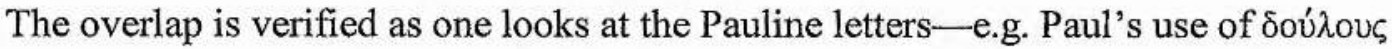

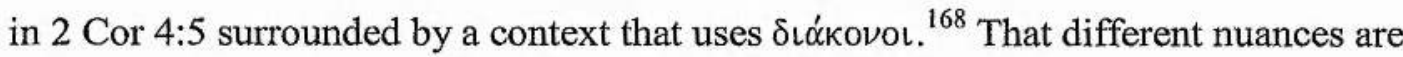
emphasized with one word over the other is not debated, but, that both Mark and Paul

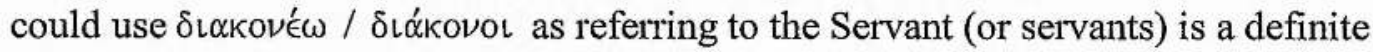
possibility. $^{169}$

The particular argument of this project will not lean heavily on Paul's terminology "servants of God" in 2 Cor 6:4, as if this lexical indicator seals the argument. More emphasis is being placed on the conceptual/figural overlap between the servants and Paul. Or, Paul's own narrative identity overlaps quite dramatically with the servants of the Servant. Also, Paul's use of new creation language in 2 Cor 5:17 (deeply connected to the restoration of the servants in Isaiah 56-66), his emphasis on receiving the "righteousness of God" in 2 Cor 5:21 (the servants are described as "righteous ones", they are the ones who have received righteousness on the basis of the Servant's work in Isaiah 53 [cf. Isa 57:1]); ${ }^{170}$ and again, Paul's narrative identity as herald and sufferer contributes to the probability of the servants of the Servant as background for Paul's thought. Isaiah's message of the Servant and the subsequent servants of the Servant are presented as eschatologically realized in Paul's descriptive account of God's current activities in Christ and himself in this Scriptural account of 2 Corinthians.

\section{4.b. Paul as Herald}

As has been emphasized, Paul is laying claim to his apostolic authority within 2 Corinthians on the basis of a self-commendation approved by the Lord. ${ }^{171}$ This undercurrent of thought and purpose continues in 2 Cor 5:14-21 and is especially

\footnotetext{
${ }^{166}$ On semantic overlap see, Moises Silva, Biblical Words and Their Meanings: An Introduction to Lexical Semantics (Grand Rapids: Zondervan, 1994), 120-129.

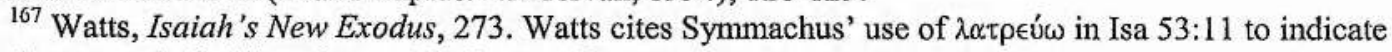
the semantic fluidity of terms for "servant".

${ }^{168}$ Watts, Isaiah's New Exodus, 274.

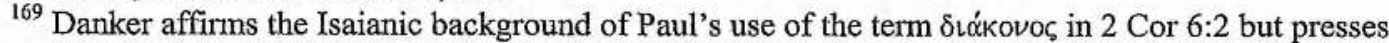
the Servant imagery over the servants imagery. In actuality, Danker is not aware of the category of servant in the plural (Danker, "The Theology," 88-89). See also Hafemann, Paul, Moses, 112 n. 69;

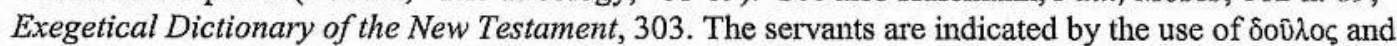
its cognates in Isa 56:6; 63:17; 65:9.

${ }^{170}$ See chapter three on this score.

${ }^{171}$ Hafemann, Suffering and Ministry in the Spirit, 74.
} 
present in 6:1-10. In 5:14-21 God's purposes of reconciling the world unto himself by means of his divine agent, Jesus Christ, is positioned as the climax of the eschatological now (6:2), and Paul's particular role in 2 Cor 5:14-6:2 is that of proclaimer / emissary of the message of reconciliation. Paul does not use the language of herald per se. But the actions of the herald are present in Paul's particular eschatological activity. This activity is relayed to the reader as Paul describes himself as "minister of reconciliation" and "ambassador" of Christ. ${ }^{172}$ Also, Paul's particular activity of announcing the new creation (5:17) and the eschatological now (6:2) is revelatory of Paul's identity as "herald".

Within the context of Paul's proclamation of God's reconciling activity in Christ, the $\delta\llcorner\alpha \kappa o \nu i ́ \alpha \nu \tau \hat{\eta} \varsigma \kappa \alpha \tau \alpha \lambda \lambda \alpha \gamma \eta \hat{\varsigma}$ is understood as the result of God's initiating reconciling activity $(5: 18)$. Paul had been reconciled (as well as the Corinthians) and subsequently he takes on the role of minister of reconciliation, that is, Paul's ministry consists in his activity as proclaimer of reconciliation. ${ }^{173}$ This reading of $\delta\llcorner\alpha \kappa o \nu i \alpha \nu$ $\tau \hat{\eta} \varsigma \kappa \alpha \tau \alpha \lambda \lambda \alpha \gamma \eta \hat{\varsigma}$ as an objective genitive is further supported in the following verses as Paul describes himself as an ambassador for Christ carrying the word of reconciliation as he announces, "Be reconciled to God.", 174

Following both Porter and Wright, it is argued that Paul's imperatival address, "Be reconciled to God," is not an address to the Corinthians per se, but is the general address given by the ambassador of Christ in the role of "minister of

\footnotetext{
${ }^{172}$ It is of interest that the United Bible Socieity's edition of the Greek New Testament identifies an allusion to Isa 52:7 in 2 Cor 5:20 (UBS, The Greek New Testament, $4^{\text {th }}$ edition, 897).

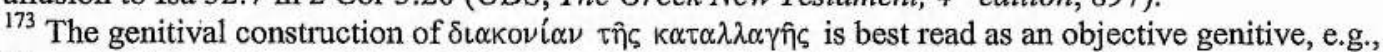
"the ministry which proclaims / offers reconciliation; the ministry which brings about reconciliation." For other options and a defense of the objective genitive see Bieringer, "Paul's Understanding of Diakonia," 422. Bieringer also argues that Paul conceives of the Corinthians and himself as having

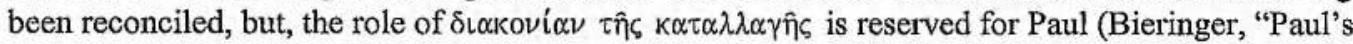
Understanding of Diakonia," 425).

${ }^{174}$ Paul speaks of himself as an ambassador of Christ in 5:20. Wright comments, "The whole point of the ambassadorial system, in the ancient as well as in the modern world, is that the sovereign himself (or herself) speaks through the agent" (Wright, "On Becoming the Righteousness of God," 206); see Bornkamm, Paul, 114; Wolff, "True Apostolic Knowledge," 94. Paul is emphasizing that God's reconciling activity is now announced by God through his ambassador. One observes a similar pattern with the servants / heralds of Isaiah 61 as they announced the good new of Lord's favor to the oppressed. This announcing is actualized by the anointing of the Spirit of God. In other words, the Spirit of God is making its appeal by means of the servants. It is possible, again, that Paul is making use of Hellenistic imagery for the sake of making accessible Old Testament Scripture in a Gentile context. The activity of the ambassador as spokesperson for God overlaps with the presentation of the servants in their narrative identity. On authorizing speech, see Nicholas Wolterstorff, Divine Discourse: Philosophical Reflections on the Claim that God Speaks (Cambridge: CUP, 1995), especially chapter 3 .
} 
reconciliation." 175 Thus, Paul's apostolic ministry as "minister of reconciliation" and "ambassador of Christ" is defined contextually by Paul's activity of announcing the good news, "Be reconciled to God." It should be stressed, however, that Paul's activity as herald / servant of reconciliation does not merely involve the objective describing of events but is intimately connected with the reality toward which the herald / servant points. ${ }^{176}$ Also, the role of Christ and the role of servant / herald are roles that need be kept distinct. Though intricately linked, the role of the servant / herald is that of pointing toward, announcing, and suffering under the Servant not that of complete identification with the Servant. Bieringer helpfully states,

For Paul, the $\delta\llcorner\alpha \kappa o \nu i \alpha$ consists of the task of presenting to the people the salvation event which happened once and for all in

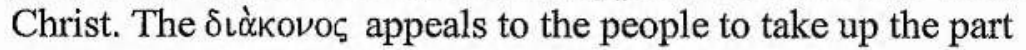
God assigned to them in completing the process of reconciliation. What $\delta\llcorner\alpha \kappa o \nu i \alpha$ means is realized in the proclamation of which the proclaimers become a part, in as much as their apostolic suffering is a participation in Christ's suffering. ${ }^{177}$

Paul's activity in this section of 2 Corinthians is that of herald of the reconciliation proffered by God through Christ and announcer of the eschatological now of God's activity. Beker states, "Like Second Isaiah, Paul interprets Israel's traditions in the light of new divine eschatological acts in history. As the apostle of Jesus Christ, Paul is the herald of the gospel of God, which announces the impending fulfillment of Second Isaiah's eschatological promise of liberation." ${ }^{178}$ As the servants of the Servant observed in retrospect the significance of the suffering Servant and announced the message of his activity (Isa $52: 7 ; 53: 1 ; 61: 1-4$ ), so to does Paul act as a

\footnotetext{
${ }^{175}$ Porter argues here that Paul is defining the Corinthians and himself as ambassadors. The use of the plural in these verses indicates an inclusive activity with which both Paul and the Corinthians are involved. This activity is speaking on behalf of God as they announce, "Be reconciled to God" (Porter,

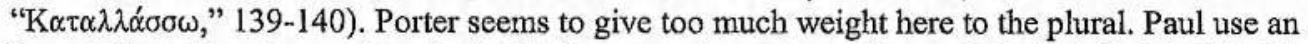
"apostolic we" quite consistently in this literary unit, as is noted especially in 5:11-15; 6:4. Therefore, Wright is more on track in his assessment that "The second half of the verse should not, I think, be taken as an address to the Corinthians specifically, but as a short and pithy statement of Paul's whole vocation: 'On behalf of Christ, we make this appeal: 'Be reconciled to God!" (Wright, "On Becoming the Righteousness of God," 205). Interestingly, Schlatter observes Paul's use of the "we" in the Thessalonian epistles and in 2 Corinthians as Paul's understanding of the centrality of the message over the personality carrying the message. The divine message, for Paul, loses none of its power when carried out by another (Schlatter, The Theology of the Apostles, 193). If this is the case, Paul's emphasizing of the centrality of the divine word over the particular personage carrying the word overlaps significantly with the message of Isaiah 40-66, a message that centers on the continuing effectiveness of the word of God (see chapter three).

${ }^{176}$ Bieringer, "Paul's Understanding of Diakonia," 428.

${ }^{177}$ Bieringer, "Paul's Understanding of Diakonia," 428.

${ }^{178}$ Beker, Paul the Apostle, 115-116. I would simply extend Beker's statement to include Isaiah 40-66.
} 
servant of Christ who announces the significance of God's work in Christ as the initiator of God's eschatological now, God's new creation. ${ }^{179}$

\section{4.c.Paul as Sufferer}

Lambrecht correctly states that Paul's "ambassadorship means more than just proclamation in words; the whole apostolic existence with all its trials is involved (cf., for example, 6:3-10)." "180 Paul's activity as herald is conjoined with Paul's identity as sufferer. It is not necessary to expound fully the definition of each type of suffering Paul lists in his catena of 6:4-6. In other words, lack of direct semantic parallel in Isaiah $40-66$ is not detrimental to the project. At this point, a thematic overlap is observed between the servants' narrative identity as sufferers and Paul's narrative identity, coupled with the proximity of the Isaianic quotation as indicator of Paul's overarching Isaianic thought. Thematically we can observe that (1) in 6:4-5 Paul defines himself as one who suffers, (2) in 6:6-7 Paul speaks of his inward moral character (this will be called Paul's righteousness), and (3) in 6:8-10 the eschatological dialectic is present.

It should also be noted that Paul is listing his own autobiographical details at this point in his self-defense. ${ }^{181} \mathrm{He}$ begins the list of suffering with an overarching

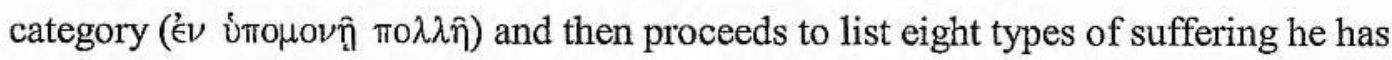

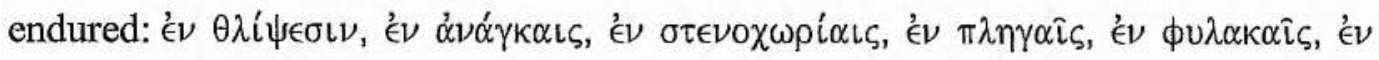

\footnotetext{
${ }^{179}$ Regarding Romans and Paul's identity as herald see, J. Ross Wagner, Heralds of the Good News: Isaiah and Paul <In Concert> in the Letter to the Romans (NTS 101; Leiden: Brill, 2002) and "The Heralds of Isaiah and the Mission of Paul," 222. Many of Wagner's conclusions support the tenor of this thesis though Wagner does not appeal to the servants of the Servant theme. Craig Evans cites Hahn's suggestion that Paul's concept of apostle is drawn from Isa 61:1. Evans combines Hahn's thoughts with his own concerning Paul's quotation of Isa 52:7 in Rom 10:15 concluding that Paul's self-identification was that of a latter day prophet whose primary vocation was that of heralding the good news (Craig A. Evans, "The Function of Isaiah in the New Testament," in Writing and Reading the Scroll of Isaiah, 687-90).

${ }^{180}$ Lambrecht, 2 Corinthians, 100.

${ }^{181}$ It has been argued that Paul's list resembles the Stoics of his time. See Fitzgerald, Cracks in an Earthen Vessel, 184-201; Thrall, II Corinthians, 454; Barrett, A Commentary on the Second Epistle to the Corinthians, 185. This observation should not delay us for long, for as we have observed Paul often makes use of images from outside the Scriptures to make accessible his theological point, a borrowed capital of sorts. Lambrecht helpfully clarifies, "Evidently the genre of the tribulation list existed and was available to him. Paul may have borrowed rhetorical commonplaces, yet he builds them into his personal compositions and incorporates them into his new faith. Moreover, the lists are, as it were, his personal, autobiographical documents" (Lambrecht, 2 Corinthians, 114). Therefore, Paul is not seeking to identify himself with the Stoics but is theologizing in the best sense of this term, that is, Paul is seeking to make the revelation of God accessible to his audience in their particular placement both in time and cultural background. Lambrecht also points out the distinctions between Paul and the Stoics (Lambrecht, 2 Corinthians, 113; see also Harvery, Renewal Through Suffering, 15-16).
} 


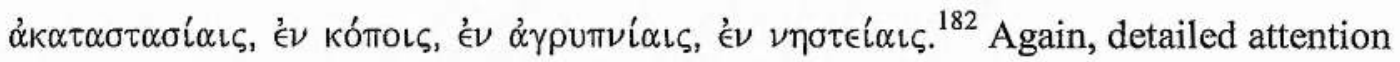
need not be given to this list. ${ }^{183}$ Theologically, however, Paul identifies himself as a sufferer and links his suffering with both the eschatological now (6:2) and a commendation appropriate for a servant of $\operatorname{God}(6: 4){ }^{184}$

Paul's theological thought as it pertains to suffering and the gospel is rich and variegated. Recently, Jervis has helpfully identified three categories by which students of Paul have identified his Leidenstheologie-1) eschatological framework (i.e., Christians suffer as an essential aspect of the apocalyptic agenda); 2) union with Christ (i.e., Christ suffered and believers suffer on the basis of union with Christ); 3) suffering of others in the history of Israel as illustrative of the current suffering. "Paul makes sense of suffering by using images and understandings of other sufferers for God." 185 Jervis' contribution is her understanding of Paul's initial preaching of the gospel as entailing the message that recipients of the gospel will suffer. ${ }^{186}$ It will suffice to say that Paul's particular thought in 2 Cor 6:3-10, as is contextually understood, falls under all three categories. Paul emphasizes the eschatological now and immediately speaks of his present suffering. Union with Christ is implicit throughout 2 Cor 5:14-21 (one died for all therefore all died), and the use of the tradition of others' sufferings, particularly the servants of the Servant, is argued for in this thesis. Hafemann helpfully states,

Moreover, Paul's self-understanding and interpretation of his weakness as an apostle are once again derived from the biblical tradition of the suffering of the righteous as confirmed and given its decisive formulation by the death of Jesus. For the 'strikingly compact reference to the context of deutero-Isaiah,' which already exists in Paul's summary of his ambassadorship and its

\footnotetext{
${ }^{182}$ Martin, 2 Corinthians, 161; Karl Theodor Kleinknecht, Der Leidende Gerechtfertigte WUNT 13, (Tübingen: JCB Mohr, 1984), 255-256.

${ }^{183}$ For detailed interaction see especially Thrall, II Corinthians, 455-459; Martin, 2 Corinthians, 170 175; Furnish, II Corinthians, 342-344, 353-355; Manus, “Apostolic Suffering," 44-46.

${ }^{184}$ Harvey, commenting on 2 Corinthians, states, "For the first time in his extant letters, and possibly for the first time in the entire philosophical and religious literature of the West, we find the experience of involuntary and innocent suffering invested with the positive value and meaning in itself' (Harvey, Renewal Through Suffering, 31).

${ }^{185}$ It should be noted that all three of these categories do not have to be operative concurrently ( L. Ann Jervis, "Accepting Affliction: Paul's Preaching on Suffering," in Character and Scripture: Moral Formation, Community, and Biblical Interpretation [ed W. P. Brown; Grand Rapids: Eerdmans, 2003], 293-297). Jervis gives the proponents of each category in footnotes.

${ }^{186}$ Jervis, "Accepting Affliction," 297. Jervis makes a convincing appeal regarding Paul's initial preaching on suffering, which is beyond the scope of our current concern.
} 
message in 5:20 6:1, is then made explicit by the quotation of $6: 2$ from the suffering servant tradition of Isaiah $49: 8 a^{187}$

Contextually, Paul places his suffering in the midst of the Isaianic drama, as his reference in 2 Cor 6:2 indicates, and, as Kleinknect has argued, in light of the righteous sufferers in the tradition-history of Israel. Though the argument presented in this project does not rely on a tradition-history approach, the volume of Paul's allusion to the suffering ones of Isaiah, the servants of the Servant, gains more resonance with the contextual understanding of both 2 Cor 5:14-6:10 and Isaiah 4066. Paul's suffering is the result of his obedient response to the call and is intricately linked with the sufferings of Christ. At the same time, Paul's sufferings are subordinated under Christ's sufferings and find their significance in that light. Again, this is the narrative identification of the servants of the Servant in Isaiah as well, sufferers who have responded in obedience and whose vocation is intricately linked with that of the Servant. Suffering for Paul was part and parcel of his activity as servant of God; it defined his being as servant. In Paul's thought this finds warrant in both the Scriptures of Israel, particularly Isaiah's redemptive drama, and in the recent activity of the suffering Christ as fulfillment of those Scriptures.

\section{4.d. Paul as Righteous}

It is recalled in our previous description of the servants to the Servant in Isaiah that a movement from righteousness as gift in Isaiah 40-55 to righteousness as covenant obedience is present. Similarly, Paul presents righteousness as gift in 2 Cor 5:21 and demonstrates his own faithful activity in 6:6-7a. Paul, though not Paul alone, has been given righteousness as a gift yet his activity is commensurate with the gift. Also, Paul's suffering is not the product of divine judgment but is commingled with his righteous status, a status of both gift and personal activity. Paul's sufferings, therefore, are the sufferings of one who is righteous, one who has embraced righteousness as gift and is acting personally in a righteous way, that is, a covenantally faithful way. ${ }^{188}$

\footnotetext{
${ }^{187}$ Hafemann, Suffering and the Ministry of the Spirit, 73. Hafemann quotes Kleinknecht, Der Leidende, 280. Kleinknecht has argued that Paul identifies his own suffering in light of the righteous sufferers in the OT and in the inter-testamental literature, 263-282.

${ }^{188}$ On Paul and obedience see Hafemann, Paul, Moses.
} 
Paul makes use of ' $\epsilon \nu$ as indicator of the manner by which he acts as servant of God. Paul's manner is one of purity (most likely referring to purity of motivation), knowledge, and patience. ${ }^{189}$ Centrally located in this list of virtues is év $\pi \nu \in u ́ \mu \alpha \tau \iota$ $\dot{\alpha} \gamma i \omega_{\varphi}$. Both Plummer and Barrett, in their respective ways, have argued against understanding this phrase as "in the Holy Spirit." ${ }^{190}$ Both doubt the presence of the "Holy Spirit" in a list of human virtues. The majority of commentators, however, disagree with both Plummer and Barrett on the basis of Paul's conjoining the Holy Spirit with human virtues elsewhere, coupled with the absence of any description of

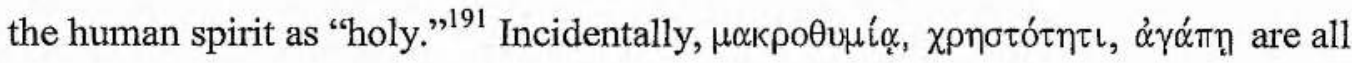
found in Paul's list of the fruit of the Spirit in Gal 5:22-23. Paul's reliance on the Holy Spirit is an authentic indicator of his legitimacy as apostle. Also, Paul's listing of the Holy Spirit in the midst of his virtuous activity clues the reader into the source of Paul's virtuous, righteous activity.

Paul's suffering is suffering in the present age, the eschatologically realized age, and is the suffering of a righteous one. Paul's righteousness is observed as both passively received $(5: 21)$ and actively demonstrated $(6: 6-7 a)$ by means of the fueling agent of the Spirit. Paul's faithful response to the divine initiative of reconciliation mediated through the Christ has resulted in Paul's own suffering in righteousness. Similarly, the servants of the Servant are identified narratively as those who are the direct recipients of the righteousness procured by the Servant (Isa 53:10) resulting in their righteous suffering in the present age (Isa 57:1). Again, the figural pattern is noted.

\section{4.e.Paul in the Eschatological Tension}

Bultmann entitled this entire section (6:3-10) "the apostle in the power of the eschatological event." ${ }^{\prime 192}$ Paul's retrospective reading of Isaiah as a realized eschatological event (2 Cor 6:2) places Paul's particular activity and suffering in the midst of the eschatological tension of God's present, inaugurating activity of Christ and the awaited day of vindication. ${ }^{193}$

\footnotetext{
189 Thrall, II Corinthians, 459; Martin, 2 Corinthians, 175.

${ }^{190}$ Plummer, II Corinthians, 196-197; Barrett, A Commentary on the Second Epistle to the Corinthians, 186-187.

${ }^{191}$ Cf. especially Gal 5:22-26; Thrall, II Corinthians, 460; Martin, 2 Corinthians, 176-177; Lambrecht, Second Corinthians, 110; Furnish, II Corinthians, 345,355.

${ }^{192}$ Buitmann, The Second Letter to the Corinthians, 167; see Hanson, The Paradox of the Cross, 63.

193 See Dumn, Theology of Paul, 466-471; Ridderbos, Paul, 44-64;
} 
Paul's list of paradoxes in 6:8-10 presents the antithesis of apparent circumstances and inward realities. ${ }^{194}$ The thought climaxes with Paul's statement, "as having nothing, and yet possessing everything" (2 Cor 6:10). ${ }^{195}$ Paul's possession of Christ, rather, Paul's being possessed by Christ, means that Paul "possesses nothing in this world." 196 Paul lives in the eschatological tension of the present age, an eschatological tension marked by his possession of everything yet his present possession of nothing. Though Paul dies, he lives (6:9). ${ }^{197}$ Paul, like the servants, is in the midst of the eschatological time of renewal initiated by God's activity mediated through the Servant. This time of renewal, however, is a time of continued suffering in the midst of the current wicked age. Though the servants and Paul had received the grace of repentance and turned toward God in obedience and confession (Isaiah 59) and though they had procured the benefits of the Servant (Isa 53:10 / 2 Cor 5:21), they still lived in the tension of fulfilled and yet not-fulfilled promises of God. ${ }^{198}$

\section{Conclusion}

Paul's eschatological role of herald and servant of God's good news is figurally presented in the narrative movement of Isaiah 53-66 most notably in the theme of the servants of the Servant. Paul has responded in obedience to the call of the Servant with faithfulness leading to his own suffering and yearning for eschatological vindication. His role as herald finds its significance in the one toward which his heralding points. The servants pointed to the Servant (Isaiah 53) and Paul points beyond himself to the Christ. Isaiah's message is an eschatological message pointing beyond itself to God's current activities in both Christ and Paul. Paul's vindication of his suffering is warranted by the canonical shape of Isaiah's eschatological message.

\footnotetext{
${ }_{194}$ Hanson, The Paradox of the Cross, 66.

${ }^{195}$ Kleinknect observes in this statement Paul's identification of himself as a righteous sufferer (Kleinknect, Der leidende Gerechtfertigte, 267-268). Mealand finds a statement similar to Paul's

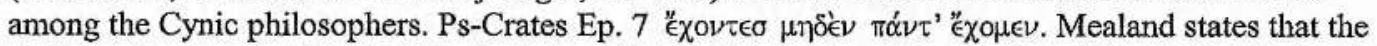
phrase was not coined by the Cynics but was "almost certainly a commonplace" (David L. Mealand, "As having nothing, and yet possessing everything [2 Kor 6 10c]" in ZNW 67 [1976]: 277-279). Mealand concludes that Paul incorporates "an old commonplace into a new faith." This supports the contention of this thesis that Paul takes cultural symbols or semiotic indicators and borrows them as he makes his theological message accessible, a theological message rooted in both God's current activity in Christ and the Scriptures of Israel.

${ }^{196}$ Martin, 2 Corinthians, 185.

${ }^{197}$ Martin states, "In summary, Paul was constantly aware of death...but God's power for triumph over death was also known to the apostle. Whether in practical terms, as he faced the 'cheating of death,' or in theological terms the eschatological travail of the man of faith, Paul was constantly both dying and living" (Martin, 2 Corinthians, 181-182).

${ }^{198}$ See Manus, "Apostolic Suffering," 50.
} 
Those who follow God in obedience suffer as did the Servant and as did Jesus. So also do the servants suffer in solidarity with the Servant, and Paul suffers in solidarity with Jesus. This is God's paradoxical means of advancing his good news and Isaiah pre-figures God's new redemptive action. 


\section{CHAPTER FIVE}

\section{THE THEOLOGICAL IMPLICATIONS OF PAUL'S OLD TESTAMENT READING}

\section{Introduction}

Having examined closely Paul's particular reading of Isaiah 40-66 and its implications for Paul's own self-awareness and the significance of God's eschatological activity in Christ, our attention comes full circle to the pressing question of hermeneutics or theological reading, the issue pointed to at the conclusion of the first chapter. ${ }^{1}$ What does Paul's reading of the OT convey to modern readers of Scripture within the community of faith, that is, to the community who recognizes Paul's apostolic status and the canonical function of his writings? ${ }^{2}$ Particularly tied to this field of inquiry will be an appeal to what Hans Frei and Brevard Childs have called a "family resemblance" in the history of interpretation. ${ }^{3}$ Does Paul's theological reading of the OT bear a familial resemblance to later Christian reading, namely, Christian reading that is defined by the sensus literalis or the plain sense of Scripture. ${ }^{4}$ Is it helpful to appropriate a category from later Christian exegesis in our description of Paul's OT reading or does such an approach fall prey to anachronism?

Without doubt, this term "plain sense" raises a host of questions, all of which will not be answered here. It should be stated, however, that an appeal to plain sense is not a neutral appeal of the bruta facta kind. In other words, what is plain to the Christian community will not necessarily be plain in the sense of a general hermeneutics accepted by those outside of the Christian community. ${ }^{5}$ In this sense, an

\footnotetext{
${ }^{1}$ For a dogmatic account of modern hermeneutics and a theological reading of Scripture see John Webster, "Hermeneutics in Modern Theology" in Church and World: Essays in Christian Dogmatics (Edinburgh: T\&T Clark, 2001), 47-86.

${ }^{2}$ Admittedly, the approach taken in this work has been narrowly defined by one particular passage. This is not to deny that Paul reads Scripture in different ways and for different purposes. What is intended is to set a particular theological framework for Paul's reading as exemplified in this particular passage.

${ }^{3}$ Hans Frei, The Eclipse of Biblical Narrative: A Study in Eighteenth and Nineteenth Century Hermeneutics (New Haven: Yale University Press, 1974); Brevard Childs, The Struggle to Understand Isaiah as Christian Scripture: A Hermeneutical Study (Grand Rapids: Eerdmans, 2004).

${ }^{4}$ Kathyrn Greene-McCreight, Ad Litteram: How Augustine, Calvin, and Barth Read the "Plain Sense" of Genesis 1-3 (New York: Peter Lang, 1998).

${ }^{5}$ On general hermeneutics and Barth's reaction to Schleiermacher's fathering of this movement in biblical studies see Richard Burnett, Karl Barth's Theological Exegesis (WUNT II/145; Tübingen: Mohr Siebeck, 2001). Jonathan Edwards, the great American theologian/philosopher, had a similar
} 
appeal to plain sense will need to be clearly defined, at least on the level of conceptual framework, as it relates to the family resemblance between it and Paul's OT reading. ${ }^{6}$ What is being intimated in this final chapter, which calls for further exploration, is the potential fruitfulness of the history of interpretation for hermeneutical questions of the day, hence the term "family resemblance." One recalls the earlier claim made in the first chapter that Paul's OT reading is sui generis. Again, this is not to say that Paul was removed from his particular place in time. Paul was no modern or postmodern and we should not expect him to be such. It is to say, however, that the context and subject matter of Paul's OT reading (and the rest of the NT authors as well) was defined by a theological criterion unique to Paul's contemporaries. A "history of religions" approach may shed light on Paul's exegetical methods but does not necessarily clarify the substance of Paul's unique reading, namely, his theological starting point. It is suggested here that if one is to gain further purchase on the theological substance and character of Paul's OT reading, a turn to the history of interpretation, with all its variegated forms and nuances, may be found helpful in this locus of inquiry. ${ }^{7}$

Coupled with the question of Paul's plain sense reading, as a theological reading, will be two other pressing questions. One, is Paul's reading of the OT to be accepted and appropriated carte blanche or is our approach to this to be more nuanced? This is a debate that is alive and well in theological discourse. Richard Hays answers the first question in the affirmative; whereas, Brevard Childs states that "we

view on typology as a Christian discipline (Jonathan Edwards, Typological Writings [The Works of Jonathan Edwards, vol. 11; ed. W. E. Anderson, M. I. Lowance, Jr.; New Haven: Yale University Press, 1993], 10).

${ }^{6}$ By way of rough analogy, David Yeago asks a similar question about the relationship between Scripture and later theological formulations, particularly the Christological formulations at Nicea. Yeago creates the categories of "judgments"-the realities presented in Scripture with Scriptural language - and "conceptual terms"- the appropriation of judgments in language different from the judgment themselves (such as homoousion). David Yeago, "The New Testament and Nicene Dogma: A Contribution to the Recovery of Theological Exegesis," in Pro Ecclesia 3 (1994): 158. Similarly, see T.F. Torrance, "The Logic and Analogic of Biblical and Theological Statements in the Greek Fathers," in Divine Meaning: Studies of Patristic Hermeneutics (Edinburgh: T\&T Clark, 1995), 374-391. Both of these authors, in their different ways, assert that the early fathers (especially Greek fathers) were not doing theology in the abstract but were seeking to conform their theological thinking with the mind and presentation of Scripture. The apostolic foundation of early theological formulations was paramount in defining biblical orthodoxy. We will seek to elucidate this analogy in relation to Paul's exegesis later in this chapter. For now, see the appeal made by the early fathers to Paul's exegesis as demonstrated in Henri de Lubac, Medieval Exegesis: The Four Senses of Scripture, vol. 2 (Edinburgh: T\&T Clark, 2000), 4-9.

${ }^{7}$ Again, Brevard Childs's recent work, The Struggle to Understand Isaiah as Christian Scripture, is exemplary in this regard. 
are not apostles and prophets" and should not simply imitate Paul's reading of the OT. ${ }^{8}$ How does one tread through these difficulties and nuances? This dissertation will argue, seeking to follow and clarify Childs, that Paul's reading of the OT does bear analogy to our reading of the OT but is not to be adopted in a facile manner.

Secondly, and in conjunction with the previous point, how does Paul's reading of the OT inform our understanding of the biblical theological task? A fundamental problem in accord with this question is the simple fact that Paul was not operating with a two-testament canon. Paul's scriptural reading was a reading of the Scriptures of Israel without a received NT canon. Fundamentally, therefore, the task of biblical theology is one step removed from Paul's reading of the OT because of the form of Christian Scripture as it has now been received, that is, a two-testament canon. In biblical theology the OT informs our reading of the NT, and the NT informs our reading of the OT. This dialectical relationship is a foundational aspect of biblical theology. Paul's understanding and use of the Old Testament still lies at the heart of biblical theology, and is a topic that needs to be continually explored. It is too simple to say that Paul has the final word on the way in which Christians should read the Old Testament. ${ }^{9}$ What can be observed theologically is Paul's pioneering role in a vocation later to be perfected via the rule of faith and the formation of a twotestament canon. Paul lays the foundation of a task that is continually being perfected as Christians, under the guidance of the Spirit, seek to hear the Word of God in Jesus Christ as revealed - and as being revealed - in the two-testament canon referred to as Christian Scripture. These are the hermeneutical/theological questions that will be explored in this final chapter, though, admittedly, the thoughts furthered here are

\footnotetext{
${ }^{8}$ Richard Hays, Echoes of Scripture in the Letters of Paul (New Haven: Yale University Press, 1998); Brevard Childs, Biblical Theology of the Old and New Testaments (Minneapolis: Fortress Press, 1992), 381. See also Christopher Seitz, "We are Not Apostles and Prophets," in Word Without End: The Old Testament as Abiding Theological Witness (Grand Rapids: Eerdmans, 1998), 100-109.

${ }^{9}$ The distinction between the discrete voice of the Old Testament as witness to Christ and the call for Christian reading of the Old Testament as the New Testament receives its-in novo receptum -is the line of demarcation between the different approaches to this subject offered by Childs/Seitz and the likes of Watson/Hübner/Stuhlmacher. See Christopher Seitz, "Christological Interpretation of Texts and Trinitarian Claims To Truth: An Engagement with Francis Watson's Text and Truth" SJT (1998): 209-226. Watson replies in turn. On Hübner's emphasis on the Old Testament in novo receptum see, Hans Hübner, "New Testament Interpretation of the Old Testament" in Hebrew Bible / Old Testament The History of Its Interpretation: Vol. I From The Beginning to the Middle Ages (ed. M. Sæbø; Göttingen:Vandenhoeck and Ruprecht, 1996), 332-372. Those familiar with Childs's conceptual development pertaining to biblical theology will recall his move away from equating biblical theology with the way the NT reads the OT toward an understanding of biblical theology as theological reflection on both the Old and New Testaments in their discrete voices. Childs, Biblical Theology, 76, 244; see also, Christopher Seitz, "We Are Not Apostles and Prophets," in Word Without End, 107-108.
} 
penultimate in form. Our attention turns first to a theological definition of the plain sense of Scripture.

\section{A Theological Definition of Plain Sense}

Paul's exegesis of the OT is a reality that must be described on its own terms and in its own theological placement. Therefore, in the following section our attention turns towards a reading of Paul's use of the OT with special attention given to its relationship to the literal sense of the text. For sake of clarity, the term "plain sense" of Scripture will be adopted for the sake of avoiding the misconceptions associated with the "literal sense." Preconceived notions of what exactly defines "plain sense" will need to be set aside as we press on to define this reality in theological terms. Our attention turns firstly to a historical question related to the use of peshat in early Jewish exegesis.

\section{2.a Peshat}

In Jewish exegesis, the term פשי is a term used to delineate the "plain" meaning of the text and is often used as a contrast to 7 or the "hidden" meaning. ${ }^{10}$ Modern sensibilities are again betrayed upon closer examination of peshat in the early Rabbinic material, even until the Talmudic period. For what is constituted as "plain" by early Jewish exegetes is not necessarily plain for those with a modernist, historicist framework of thinking. Sternberger states, "In the Talmudic period, even the peshat is not the simple literal meaning, but often merely an opinion sanctified by long tradition or teaching authority."11

\footnotetext{
${ }^{10}$ David Istone-Brewer, Techniques and Assumptions, 14.

${ }^{11}$ Sternberger, Introduction to the Talmud and Midrash, 235. Instone-Brewer (Techniques and Assumptions, 169) makes a similar statement with regard to Scribal exegesis (pre 70 C.E.). InstoneBrewer claims that Scribal exegesis did not seek a second meaning in Scripture but always sought to find the plain or primary sense of the text. He concludes, however, by saying, "What the Scribes regarded as the primary sense may be very different from what a modern exegete would accept as the original intention of the authors of Scripture." Instone-Brewer's (Techniques and Assumptions, 165171) conclusions about Scribal exegetical assumptions are as follows: 1) Scripture is totally selfconsistent; 2) Every detail in Scripture is significant; 3) Scripture is understood according to its context; 4) Scripture does not have a secondary meaning; 5) There is only one valid text form of Scripture. This amounts to a Nomological approach to Scripture, that is, reading Scripture with all the "stringency and accuracy" attached to the reading of a legal document. Techniques and Assumptions, 15,171 . Of these five conclusions, only the first two are found in almost all rabbinic literature. This dissemination led to the necessity of clearly distinguishing between peshat and derash by later rabbis. Techniques and Assumptions, 172.
} 
One of the most important works, for this particular project, is the investigatory study of "plain sense" in early Jewish exegesis by Ralph Loewe. ${ }^{12}$ The simple differentiation between the plain sense as the literal sense in distinction from derash or the homiletical sense "has been dealt a major blow" by Loewe's study. ${ }^{13}$ Peshat is initially defined by Loewe as the "straightforward, or simple exegesis which corresponds to the totality of the meaning (s) intended by the writer." ${ }^{14}$ Having defined peshat thus, Loewe then describes the ways in which the term peshat is deployed in the Talmudic period concluding that such an abstract or ideal definition of plain sense does not live up to the test.

Loewe states that the fundamental meaning of פשי is "to strip (a garment), properly to flatten it by doing so." ${ }^{15}$ Therefore, when the term פשת is used passively it can be semantically stretched into meanings such as "flat, straight, simple, uncompounded, innocent, unlearned." ${ }^{16}$ Loewe concludes his lexical discussion by stating that the definition of פשי as "explain" (a definition found at least till the end of the amoraic period) is a virtual solecism of Hebrew and Jewish Aramaic usage. ${ }^{17}$ Loewe then gives his revised definition of peshat. The essential notion related to this term is "authority." "I8 "If this is correct, the meaning is but a natural semantic development of the meaning extend - viz. the extension of an opinion, received by a teacher or elaborated by himself, over a wider body which (by acknowledgment thereof) broadens the currency of the authority of the source whence it emanates." ${ }^{19}$ If authority is the central notion of peshat, Loewe contends, then its use in talmudic and midrashic sources "describe exegesis that is by no means always literal.",20

What was plain about the plain sense in early Jewish exegesis was not necessarily its literalness (in a modern sense of the term) but its acceptance as

\footnotetext{
${ }^{12}$ Ralph Loewe, "The 'Plain' Meaning of Scripture in Early Jewish Exegesis," in Papers for the Institute of Jewish Studies London: Vol. I, ed. by J.G. Weiss, (Jerusalem: Magnes Press 1964), 140185.

${ }^{13}$ Brevard Childs, "The Sensus Literalis of Scripture: An Ancient and Modern Problem," in Beiträge zur Alttestamentalichen Theologie: Festschrift für Walther Zimmerli zum 70 Geburstag (Göttingen: Vandenhoeck and Ruprecht, 1977), 80.

${ }^{14}$ Loewe, The 'Plain' Meaning of Scripture, 141-142.

${ }^{15}$ Loewe, The 'Plain' Meaning of Scripture, 155. On "plain sense" in Rabbinic literature as "context" see Daniel Halivni, Peshat and Derash: Plai and Applied Meaning in Rabinic Exegesis (New York: Oxford Press, 1991).

${ }^{16}$ Loewe, The 'Plain' Meaning of Scripture, 155.

${ }^{17}$ Loewe, The 'Plain' Meaning of Scripture, 155-156.

${ }^{18}$ Loewe, The 'Plain' Meaning of Scripture, 158.

${ }^{19}$ Loewe, The 'Plain' Meaning of Scripture, 158.

${ }^{20}$ Loewe, The 'Plain' Meaning of Scripture, 159.
} 
traditionally authoritative. ${ }^{21}$ Therefore, the strong distinction between derash and peshat should not be pressed too hard. "The real distinction between them as nouns seems to be that derash is exegesis naturally, or even experimentally propounded without secondary considerations; if it is popularly received, and transmitted into the body of conventional or "orthodox' opinion, it crystallizes into peshat." 22 As this cursory exploration into peshat or plain sense in early Jewish exegesis displays, defining the plain sense or the sensus literalis is both "an ancient and modern problem" in need of clarification, more specifically, theological clarification. Our attention, therefore, turns to Brevard Childs's theological and historical reflection on the sensus literalis.

\section{2.b Brevard Childs on the Sensus Literalis}

Defining the sensus literalis is, for Childs, an important yet difficult task for modern exegetes. Turning his attention to the synagogue first, Childs rehearses Loewe's argument on peshat with the conclusion that what moderns often mean by "literal" is not to be identified with the "plain sense" of early Jewish exegetes. Childs continues, in cursory fashion, to explore the various ways the sensus literalis has been employed in the church, e.g., Origen, Augstine, Hugh of St. Victor, Aquinas, Nicholas of Lyra, Luther, Calvin, and Jowett. Benjamin Jowett represents a turning point in the use and appeal to the sensus literalis. ${ }^{23}$ Fully planted in the modern period, Jowett claimed

\footnotetext{
${ }^{21}$ Loewe, The 'Plain' Meaning of Scripture, 181.

${ }^{22}$ Loewe, The 'Plain' Meaning of Scripture, 183.

${ }^{23}$ Childs characterizes the medieval approach as an approach that also sought meaning outside the text itself with its four-fold approach. This non-textual approach was the source of Calvin's castigation of allegorical reading. It does not follow, however, that Calvin read the literal sense as the historical sense alone. For Scripture, in Calvin's worldview, faithfully communicates the word of God and points to the reality of God's actions in the world, namely, in Jesus Christ (see Richard Burnett, "John Calvin and the Sensus Literalis," in SJT 57 (2004): 1-13). As Neil MacDonald has argued, it is not that in the precritical period one did not think things took place historically. This was doubtless part of their basic belief structure. The meaning of the text, though, is not to be identified with its historicity. Neil MacDonald, "Illocutionary Stance," 319. Though the approaches to Scripture are varied in the precritical period, the overlap is found in the fact that no dichotomy was ever present between the literal sense and the theological or spiritual sense of the text. Childs ("The Sensus Literalis," 87) characterizes this framework in the following way: "Yet to restrict biblical interpretation to a strictly grammatical reading seemed to threaten the whole theological dimension of the bible as it related both to teaching and practice." It should also be noted that Calvin is Childs's figure of choice in the pre-critical era, at least in this particular article. Scalise follows and elaborates on Childs in his "The 'Sensus Literalis': Hermeneutical Key to Biblical Exegesis," SJT 42 (1989): 45-65. See also, David C. Steinmetz, "The Superiority of Pre-Critical Exegesis," in The Theological Interpretation of Scripture: Classic and Contemporary Readings (ed. S. Fowl; Oxford: Blackwell's Press, 1997), 26-38; Daniel J. Treier, "The Superiority of Pre-Critical Exegesis? Sic Et Non," TrinJ 24 (2003): 77-103. On Calvin's Christocentric
} 
that the Bible was to be read as any other book as the interpreter seeks to recover the original meaning. ${ }^{24}$ This original meaning is to be identified with "the meaning, that is, of the words as they first struck on the ears or flashed before the eyes of those who heard and read them." 25 As Jowett's quote betrays, in the modern period the sensus literalis became identified with the sensus originalis or the sensus historicus. ${ }^{26}$ The meaning of the text was reduced to the historical reference of the text. ${ }^{27}$

In Childs's estimation this move in the modern period of equating the sensus literalis with the sensus historicus has had mostly negative effects on the task of biblical interpretation. Childs lists four effects of historical-criticism on defining the sensus literalis. First, identifying the literal sense with the historical sense moves the question beyond a textual question to a historical reality found behind the text. Thus, the text itself loses its significance as it becomes a means to an historical end. ${ }^{28}$ Secondly, identifying the literal sense with the historical sense makes the biblical interpretive task a speculative one. ${ }^{29}$ In other words, the text is dissolved into a plethora of "speculative theories of historical and literary reconstruction." 30 Thirdly, identifying the literal sense with the historical sense displaces the Scripture from the community of faith, whether Jewish or Christian. Finally, the historical critical approach seriously damages the religious use of the Bible. The historical critical approach teeters on the precipice of Lessing's ugly ditch with the following result:

reading of the OT see Karl Barth, The Theology of John Calvin (transl. G. Bromiley; Grand Rapids: Eerdmans, 1995), 164-167.

${ }^{24}$ Childs, "The Sensus Literalis," 89. Paul R. Noble tracks the debate between James Barr and Brevard Childs on the nature of the literal sense and the modern historical-critical approach. Barr is a stringent defender of the historical-critical project and thinks Childs mischaracterizes both modern approaches to biblical scholarship and Benjamin Jowett. Paul R. Noble, "The Sensus Literalis: Jowett, Childs, and Barr," in JTS 44 (1993): 1-23. Childs responds to Barr with puzzlement, claiming that Barr's definition of a historical approach is so narrowly defined it borders on the absurd. Brevard Childs, "Critical Reflections on James Barr's Understanding of the Literal Sense and the Allegorical," in JSOT 46 (1990): 3-9, esp. 6-7.

${ }^{25}$ Childs, "The Sensus Literalis," 89.

${ }^{26}$ Childs, "The Sensus Literalis," 88-89. Childs refers to Hans Frei's. The Eclipse of Biblical Narrative. Frei's work traces the historical development of this phenomenon of equating the literal sense with a historical sense.

${ }^{27}$ One notes Raymond Browns definition of the literal sense as placed in this modern, historicist construct. "The literal sense means what the biblical authors intended and conveyed to their audiences by what they wrote" (An Introduction to the New Testament [New York: Doubleday, 1996], 35). See also, Raymond Brown, "The Literal Sense of Scripture," in The Jerome Biblical Commentary (ed. R. Brown, J. Fitzmeyer, J. Murphy; New Jersey: Prentice-Hall, 1968), 606-610. Richard Longenecker (Biblical Exegesis, xxxii-xxxiii) follows Brown's definition of the literal sense as the sensus originalis. ${ }^{28}$ Childs, "The Sensus Literalis," 90.

${ }^{29}$ Childs, "The Sensus Literalis," 90.

${ }^{30}$ Childs, "The Sensus Literalis," 90-91. 
"An almost insurmountable gap has arisen between the historical sense of the text, now fully anchored in the historical past, and the search for its present relevance for the modern age." 31 From this negative appraisal, Childs moves to a positive construction for defining the sensus literalis. In Childs's estimation, this inquiry is one of the "burning issues of theology." 32

Childs does not claim to provide the final word on a theological definition of the sensus literalis. The following four suggestions are termed "modest proposals."33 First, the object of biblical exegesis is the text itself coupled with the subject matter of which the text speaks. "The study of the text cannot be separated from its reality, nor can its reality be divorced from the text." 34 This would presuppose the text as both inspired and revelatory. Secondly, the biblical text must be studied in conjunction with the community of faith which treasured it. ${ }^{35}$ This is not to preclude the text from being studied from other perspectives, although, if one wishes to study the text of Sacred Scripture a commitment to canon must be a major part of the framework. Childs states, "The literal sense of the text is the plain sense witnessed to by the community of faith." ${ }^{36}$ This places the literal sense in a theological realm as a critical norm for the community of faith. Therefore, canon is not merely an extrinsic category placed on Scripture indiscriminately by the magisterium but is a recognition of the authority the biblical text itself exerts on the community of faith. In short, "there can be no genuine sensus literalis apart from a commitment to canon."37 Thirdly, Lessing's ditch is overcome by not placing the literal sense in stark tension with the figurative sense of Scripture. Both the literal and figural senses are critical and conjoined in the continuing actualization of the text. ${ }^{38}$ It follows, therefore, that lastly, the Holy Spirit must play a central role in defining the sensus literalis. For the Spirit does not add a new dimension to the literal sense of the text but is involved in its actualization to every succeeding generation of the church. ${ }^{39}$ Again, the literal sense is

${ }^{31}$ Childs, "The Sensus Literalis," 91.

${ }^{32}$ Childs, "The Sensus Literalis," 92.

${ }^{33}$ Childs, "The Sensus Literalis," 92.

${ }^{34}$ Childs, "The Sensus Literalis," 92.

${ }^{35}$ Childs, "The Sensus Literalis," 92.

${ }^{36}$ Childs, "The Sensus Literalis," 92.

${ }^{37}$ Childs, "The Sensus Literalis," 93.

${ }^{38}$ Childs, "The Sensus Literalis," 93.

${ }^{39}$ Childs, "The Sensus Literalis," 93. 
not destroyed by its figural capacity but offers a stabilizing referent point for future generations seeking to hear the text in their time.

Childs's work on the sensus literalis broke new ground in raising the awareness of the historical and epistemological movement in the defining of this term in the pre-critical and critical era. The collapsing of the sensus literalis onto the sensus historicus has in effect eclipsed the biblical material of its figural capacity to speak to succeeding generations. Childs's work will serve as an important backdrop to the following theological definition of the plain sense as it will be employed in this project. It follows, therefore, to explore the relationship between the figural and literal sense of Scripture.

\section{2.c The Literal Sense and Figural Sense}

A key area of inquiry in seeking to define the plain sense of Scripture from a theological perspective is to take into account the relationship between the literal sense (baldly defined as the semantic-grammatical sense of the text or the narrative coherence of the text) and the figural sense of Scripture. ${ }^{40}$ Put in other terms, is a Christian interpretation of the OT from a Christocentric or Trinitarian perspective a germane reading of the text itself or is it an alien imposition placed on the text ${ }^{41}$

Without doubt this quickly takes the reader into the realm of theology. The quest for an "objectively demonstrated" procedure of the neutral sort that can be claimed by both Christian and non-Christian in the competing sphere of ideas and agreed upon definitions is beyond the scope of defining plain sense. As Dawson states, "The claim that Christian figural reading is a legitimate or even persuasive extension of the literal sense is a distinctively Christian, theological claim, which nonChristians, preserving to the full their non-Christian identities, might justifiably reject." 42 A Christian reading of Scripture, as pioneered and demonstrated by Paul, assumes an eschatological context in which God's redemptive and soteric activities

\footnotetext{
${ }^{40}$ For Origen, the literal sense was nothing other than "the brute materiality of the words." See J. P. Leinhard, "Origen and the Crisis of the Old Testament in the Early Church," in Pro Ecclesia IX (2000): 363.

${ }^{41}$ The term "alien imposition" is adapted from Noble's (The Canonical Approach, 326) critique of Childs's Christological interpretation of the OT in his Biblical Theology. On this issue see especially, C. Kavin Rowe, "Trinitarian Hermeneutics" and "Luke and the Trinity: an Essay in Ecclesial Biblical Theology," in SJT 56 (2003), 1-26; Bruce Marshall, Trinity and Truth (Cambridge: Cambridge University Press, 1999), 34-39; Robert Jenson, "The Bible and the Trinity," in Pro Ecclesia XI (2002): 329-339.

${ }^{42}$ Dawson, Christian Figural Reading, 174.
} 
have been concretely defined by God's action in Jesus Christ ( 2 Cor 5:18-19). The overarching divine economy of God, which includes the OT, culminates and is defined by Jesus Christ. ${ }^{43}$ Therefore, to read the OT as an eschatological indicator of God's actions in Christ is not a variant reading of the imposing kind but, within the Christian worldview, is the only proper reading taking into account the ultimate subject matter of Scripture.

What then is the relationship between the figural and literal sense of the text? Hans Frei's Eclipse of Biblical Narrative addresses this fundamental distinguishing feature between pre-critical exegesis (especially with the likes of Calvin) and critical exegesis. For in pre-critical exegesis typological or figural readings were not conceived of as an imposition onto the text but were viewed as a "natural extension" of the text. ${ }^{44}$ The literal sense of the text was not, therefore, in competition with the figural sense or theological sense. Both were viewed as intimately and intricately related in an organic fashion. ${ }^{45}$

Frei's work traces the breakdown in the modern period between the literal sense and the figural sense of Scripture. This movement within the modern period of distancing the literal-realistic reading of Scripture from the real world resulted in the "collapse of figural interpretation." ${ }^{46}$ In the pre-critical era figural reading was itself a "literalism extended to the whole story or the unitary canon containing it." ${ }^{47}$ In the critical era, however, the figural sense of Scripture became the opposite of the literal sense. ${ }^{48}$ A single meaning was now found in the literal sense of Scripture so that figural readings became a "senseless exception" to that rule. ${ }^{49} \mathrm{Also}$, any unity within the Bible's message itself was distanced from the self-contained literal reading of specific texts. Resultantly, Frei defines the literal sense of the modern period as two things: "grammatical and lexical exactness in estimating what the original sense of a text was to its original audience, and the coincidence of the description with how the

\footnotetext{
${ }^{43}$ Dawson, Christian Figural Reading, 164.

${ }^{44}$ Frei, Eclipse, 2. See Campbell, Preaching Jesus, chapter four; David Lee, Luke's Story of Jesus: Theological Reading of Gospel and the Legacy of Hans Frei (ISNTS 185; Sheffield: Sheffield Academic Press, 1999), chapter three. Both of these authors trace the development of Frei's thought from a realistic narrative approach to a cultural-linguistic approach with relation to the sensus literalis. ${ }^{45}$ See Kevin Vanhoozer, "The Spirit of Understanding: Special Revelation and General Hermeneutics" in Disciplining Hermeneutics: Interpretation in Christian Perspective (ed. R. Lundin; Grand Rapids: Eerdmans, 1997), 131-165.

${ }^{46}$ Frei, Eclipse, 6.

${ }^{47}$ Frei, Eclipse, 7.

${ }^{48}$ Frei, Eclipse, 7.

${ }^{49}$ Frei, Eclipse, 7.
} 
facts really occurred." ${ }^{50}$ Figural reading, in light of this definition, lost credulity in the modern period as the literal sense became conflated with the sensus historicus or sensus originalis more narrowly defined.

Frei describes the pre-critical era, with Luther and Calvin as its key exemplary figures, as a time in which literal and figural readings of Scripture were happily wed to one another. Calvin and Luther, though Calvin tended to be more nuanced and careful in his approach, both affirmed that the Old and New Testaments share a common subject matter, Jesus Christ. ${ }^{51}$ For Calvin, the internal testimony of the Spirit and the actual words of the texts conjoined as the Spirit illumines the reader to the religious value of the text. This is not an ancillary or peripheral exegetical principle for Calvin but a proper stance in one's understanding of God as speaking through his word. $^{52}$ This conjoining of Spirit and text coupled with an understanding of Scripture's subject matter as Jesus Christ led Calvin to understand the natural coherence between the literal sense and the figural sense with each sense supplementing the other. ${ }^{53}$ The literal sense of particular texts set forth the sense of single stories within the Bible, "holding together their explicative meaning, and where appropriate, their real reference." ${ }^{54}$ While on the other hand, figural reading is a grasp of a "common pattern of occurrences and meaning together." 55 This pattern holds true under the "unitary temporal sequence which allows all the single narrations within it to become part of single narration." ${ }^{, 56}$ This understanding of single stories as patterns within a larger story was for Calvin not an imposition onto the text but a necessary implication of the narrative itself. ${ }^{57}$

Dawson helpfully charters one through the difficulties of understanding the organic relationship between the literal sense and the figural sense in his reading of Frei. He states, "In other words, to say that literal meaning extends into figural meaning is to reject the idea that what is figural must be nonliteral, or that in figural,

\footnotetext{
${ }^{50}$ Frei, Eclipse, 7.

${ }^{51}$ Frei, Eclipse, 20.

${ }^{52}$ Frei, Eclipse, 22. John Calvin, Institutes of Christian Religion (LCC 20; trans1. F.L. Battles; Philadelphia: The Westminster Press, 1960), Book I, 7. 4, 5.

${ }^{53}$ Frei, Eclipse, 27. Burnett ("John Calvin and the Sensus Literalis," 12) states that though Calvin was concerned with the literal sense of the text, he was by no means a "literalist."

${ }^{54}$ Frei, Eclipse, 34.

${ }^{55}$ Frei, Eclipse, 34; Institutes, II, 11. 4.

${ }^{56}$ Frei, Eclipse, 34.

${ }^{57}$ Frei, Eclipse, 35; Institutes, II, 11. 1,2. See also Campbell, Preaching Jesus, 100 n. 48; Burnett,

"John Calvin and the Sensus Literalis."
} 
the literal can no longer be present. Instead, when a narrative is read figurally, the reader stresses a certain feature of the text that differs from, but does not contradict, the feature of the narrative that would be stressed in a literal reading. ${ }^{, 58}$ Calvin stresses that the figures of Scripture do not have a meaning in their own right but are caught into another reality where they prefigure what is to come. ${ }^{59}$ But this does not mean that this figural extension diminishes or calls into question the "truth and reality" of the person or events depicted in their own time. ${ }^{60}$ Rather, "Figural extension of literality means that a real person or event has an additional (and, hence, a new) meaning that does not detract from (but is rather the fuller meaning of) its truth and reality previously open to literal depiction." ${ }^{61}$ A Christian reading of the OT is, therefore, a reading that takes seriously the literal sense of the text in its unique temporal setting coupled with the reality of this unique temporal setting being caught into another realm of divinely ordered sequence in which figure and fulfillment mutually correspond to one another and inform one another. The figural extension of the literal sense is an organic relationship between text or figure and the reality toward which it points and signifies. A plain sense reading of Scripture would take into account both of these aspects as mutually coinciding with one another in what Frei terms, "a family resemblance." 62 What then is a proper figural reading of the text? To this question our attention now turns.

\footnotetext{
${ }^{58}$ Dawson, Christian Figural Reading, 147. Dawson (Christian Figural Reading, 148) also gives three rules of figural extension. They are 1) A delicate balance must be struck between figure and fulfillment so that the figure is not lost in the fulfillment; 2) A firm connection between the historical reality of both the figure and the fulfillment; 3) A clear rooting of the figure, the fulfillment, and the larger story they tell in the temporal flow of ordinary historical events, a rooting that does not depend on a nonprovidential, scientific-historical understanding of the historical relation between event.

${ }^{59}$ Frei, Eclipse, 33 ; Institutes, II, 11. 1,2. This relationship between the literal sense and the figural sense is observed in Nicholas of Lyra's allowing for two literal senses or a duplex sensus literalis. Ghoush states that "Such a 'literal' sense encompasses both the surface, immediate meaning of the scriptural words as well as the figurative or christological meaning" (Kantik Ghosh, The Wycliffite Heresy: Authority and the Interpretation of Texts [Cambridge Studies in Medieval Literature 45; Cambrdige: CUP, 2002], 13). This lines up quite well with the emphasis of this final chapter, that is, the plain sense of Scripture entails both the literal and figural potential of Scripture in its Christological framework. Ghosh (14) describes the renewed interest in the literal sense of Scripture in figures such as Aquina, Nicholas of Lyra, and Fitzralph as a redefinition of the literal sense. "The older distinction between the 'literal' and the 'spiritual' is recast as a distinction between two aspects of the 'literal"' (14).

${ }^{60}$ Dawson, Christian Figural Reading, 151.

${ }^{61}$ Dawson, Christian Figural Reading, 151. Dawson (Christian Figural Reading, 155) continues to state that Christian figural reading is without question a reading back from the standpoint of the fulfillment prefigured in persons and events, although, the glance backward can only be gained by a prior reading forward from figure to fulfillment.

${ }^{62}$ Frei, Eclipse, 27, 33. Timothy Ward, citing Smalley, states that Hugh of St. Victor (d. 1141) had a sophisticated understanding of the literal sense (Timothy Ward, Word and Supplement: Speech Acts,
} 


\section{2.c.i Typology and Allegory}

Typology, in the language of Frei, is another way of saying figurative reading - the equivalent of typology in Latin is figura - and has often been set over against allegorical readings of Scripture, namely, in an attempt to protect the historicity of the documents. ${ }^{63}$ Where it is assumed that allegory destroyed the historicity of the text, typology, on the other hand, took history seriously. This sharp distinction between allegory and typology is being called into question by several scholars. ${ }^{64}$ Especially in reference to patristic exegetes (the term typology is not found among them), what would today be called typology is for the patristic writers allegory. ${ }^{65}$ They were one in the same. It may be safe to say that the difference between allegory and typology is a difference of degree and not kind. This needs further exploration.

Frances Young is especially helpful on this score in her reading of early Christian exegesis and typology/allegory. History, in the sense of historicity and facticity of the modernist sort, was not a primary concern for ancient exegetes "and they made no self-conscious connection between history and typology of the kind proposed." $" 66$ This is observed especially in the debates between the Antiochenes and the Alexandrians. It is a very facile distinction to describe the two approaches as literal versus allegorical exegesis. Young, relying on Froehlich, shows that in an Antiochene such as Diodore historia is not in opposition to theoria (insight) or

\footnotetext{
Biblical Texts, and the Sufficiency of Scripture [Oxford: OUP, 2002], 32-33). The literal sense for Hugh of St. Victor was not reduced to the word but to what the text means. Therefore, the meaning of the text may be figural and thus this figural reading is the text's literal sense. See also, Beryl Smalley, The Study of the Bible in the Middle Ages, $3^{\text {rd }}$ edn. (Oxford: Blackwell, 1983) 89, 93; G. R. Evans, The Language and Logic of the Bible: The Road to Reformation (Cambridge: CUP, 1985), 42-50.

${ }^{63}$ Frances Young, "Typology" in Crossing the Boundaries: Essays in Biblical Interpretation in Honour of Michael D. Goulder (BIS 8; Leiden: Brill, 1994), 31. See G.W.H. Lampe and K. J. Woollcombe, Essays on Typology (Studies in Biblical Theology 22; London: SCM Press, 1957) and Leonhard Goppelt, Typos: The Typological Interpretation of the Old Testament in the New (transl. D. H. Madvig; Grand Rapids: Eerdmans, 1982), Jean Daniélou, The Lord of History: Reflections on the Inner Meaning of History (trans1. N. Abercrombie, London: Longmans, 1958), R.P.C. Hanson, Allegory and Event: A Study of the Sources and Significance of Origen's Interpretation of Scripture (Louisville: Westminster/John Knox, 2002).

${ }^{64}$ Frances Young, "Typology;" Biblical Exegesis; Brevard Childs, "Allegory and Typology within Biblical Interpretation" unpublished paper presented at University of St. Andrews, 2000; Andrew Louth, "Return to Allegory" in Discerning the Mystery: An Essay on the Nature of Theology (Clarendon: Oxford Press, 1983), 98-130; Henri de Lubac, "Spiritual Understanding" in Theological Interpretation of Scripture: Classic and Contemporary Readings (ed. S. Fowl; Oxford: Blackwell, 1997), 3-25, Medieval Exegesis; Christopher Seitz, Figured Out.

${ }^{65}$ Louth, "Return to Allegory," 118.

${ }^{66}$ Young, "Typology," 34.
} 
elevated truth but is its very foundation. ${ }^{67}$ Historia is not an appeal to history as in modernist parlance but is an appeal toward attendance to the wording and the story of the text itself. ${ }^{68}$ The story itself provides the framework for elevated thought about the passage or figural reading. The allegory of the Alexandrians that was objected to by the Antiochenes was not an opposition to allegory or figural reading per se. ${ }^{69}$ As Young and others have demonstrated they were both involved in figural readings. ${ }^{70}$ "What they resisted was the type of allegory that destroyed textual coherence." $" 71$ This textual coherence or sequence, akoloutheia, preserves the integrity and content of the text, skopos, and was not opposed to figural readings but actually facilitated those readings of Scripture. ${ }^{72}$

Typology, as a subset of allegory, is tied closely to mimesis or

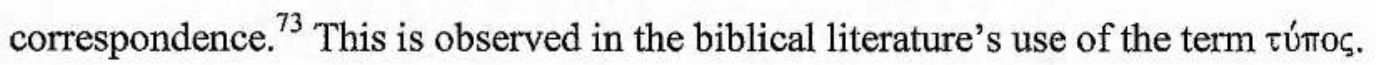
Like the "impress" left in Jesus hands from the nails (Jn 20:25), so to is a

\footnotetext{
${ }^{67}$ Young, Biblical Exegesis, 175. Karlfried Froehlich, Biblical Interpretation in the Early Church (Philadelphia: Fortress Press, 1984), 85.

${ }^{68}$ Young, Biblical Exegesis, 175. This also reveals the naïve assumption at work in early exegetes that the text mirrored history. See Morweena Ludlow, "Theology and Allegory: Origen and Gregory of Nyssa on the Unity and Diversity of Scripture," in IJST 4 (2002): 45-66.

${ }^{69}$ Young pursues the difference between the Alexandrians and Antiochenes on the basis of their differing educational backgrounds, philosophical schools versus rhetorical schools. Frances Young, "The Rhetorical Schools and Their Influence on Patristic Exegesis" in The Making of Orthodoxy: Essays in Honour of Henry Chadwick (ed. R. Williams; Cambridge: Cambridge University Press, 1987), 182-199.

${ }^{70}$ John J. O'Keefe, “ 'A Letter that Killeth': Toward a Reassessment of Antiochene Exegesis, or
} Diodore, Theodore, and Theodoret on the Psalms," in JECS 8 (2000): 88. O'Keefe is not as positive on Antiochene exegesis as Young is and characterizes Antiochene exegesis of the OT as exegesis opposed to figural reading (O'Keefe, "A Letter that Killeth," 94).

${ }^{71}$ Young, Biblical Exegesis, 176. Two categories are developed by Young (Biblical Exegesis, 162-163) to help show the difference between these two approaches: ikonic mimesis (Antiochenes) and symbolic mimesis (Alexandrians). Ikonic exegesis mirrors the deeper meaning in the text as coherent whole. Symbolic exegesis uses words as symbols and tokens referring to another reality with the application of a code, thus, destroying the narrative, or surface coherence of the text. She states, "What is different is the assumption that the narrative provides a kind of 'mirror' which images the true understanding, rather than the words of the text providing a code to be cracked." See also, T. F. Torrance, "The Hermeneutics of Athanasius," in Divine Meaning: Studies in Patristic Hermeneutics (Edinburgh: T\&T Clark, 1995), 229-288, and "The Logic and Analogic of Biblical and Theological Statements in the Greek Fathers," in Divine Meaning, 374-391.

${ }^{72}$ On akolouthia in Gregory of Nyssa and Origen see Ludlow, "Theology and Allegory." Gregory's exegetical attentions are focused on the over-all aim of the text (skopos) and believes that sequence of the text itself, its akolouthia, reveals the text's intention. Ludlow, "Theology and Allegory," 54. Young states, "The Antiochenes were concerned with what we might call the 'narrative logic' of the whole text - its oкomós, its content, its context - and in the 'moral' or 'dogmatic' meaning which could be discerned in the whole - inhering in it, as it were...As we have seen, they were not averse to exegetical practices which appear distinctly allegorical to us; but they were averse to arbitrary exegesis which took away the from the 'plain sense' of scripture." Frances Young, "Exegetical Method and Scriptural Proof," in StPatr XIX (1989): 303.

${ }^{73}$ See Erich Auerbach, Mimesis: The Representation of Reality in Western Literature (Princeton: Princeton University Press, 2003). 
corresponding relationship observed between type and antitype. ${ }^{74}$ Also, it is important to note that in the biblical usage the antitype (fulfillment) actually precedes the type signifying the eschatological and transcendent sphere in which this inquiry is placed. ${ }^{75}$ Typology's distinct definition is relegated to the realm of correspondence and defines typology thus. Typology finds a deeper significance within the text, whether persons or events, as mirroring or mimicking something else in a corresponding relationship. In the biblical material, this corresponding relationship takes place not only in linear development but in an eschatological sphere of reality inaugurated by Christ. It is this correspondence or prefiguration that distinguishes typology as a subset of the larger category of allegory. ${ }^{76}$ Thus, a difference in degree and not kind is noted. ${ }^{77}$ Both allegory and typology, when done well, are appeals to the letter of the text as pointing to a spiritual reality beyond it and are not means of divorcing the letter from the spirit. $^{78}$

The relationship between the literal sense of Scripture and its figural capacity in God's eschatological economy is observed in Paul's reading of Isaiah 40-66 in 2 Cor 5:14-6:10. Paul's reading of the Isaianic drama cannot be defined as baldly literal in the sense that faithful reading of the text is a reading that gives precedence to sensus historicus. Rather, Paul understands Isaiah as that continuing word of the Lord that presents the gospel in miniature form with its various personae at work in the eschatological now. The Servant in Isaiah's own discrete voice has a unique identity that is not transferable to one like Paul, and Paul recognizes the ontological union between the Servant of Isaiah 40-55 and Jesus Christ in 2 Cor 5:14-21. Likewise, Paul places his own eschatologically realized identity in the camp of the servants of the Servant. They, in figural fashion, provide a divinely ordered pattern for the ways in which God would further the work of the Servant.

\footnotetext{
${ }^{74}$ Young, "Typology," 34-35. Cf. Rom 5:14; Heb 9:24; I Pet 3:20-21.

${ }^{75}$ Young, "Typology," 38.

${ }^{76}$ William Horbury, "Old Testament Interpretation in the Writings of the Church Fathers" in Mikra: Text, Translation, Reading and Interpretation of the Hebrew Bible in Ancient Judaism and Early Christianity (ed. M. J. Mulder; Philadelphia: Fortress Press, 1988), 766-767.

${ }^{77}$ See Bauckham's discussion of eschatological prophecy and eschatological typology in Jude and the Relatives of Jesus, 217-218; see also Fishbane's (Biblical Interpretation in Ancient Israel, 350-379) discussion of the various forms of typology present in the inner-biblical exegesis of the OT itself. ${ }^{78}$ Henri de Lubac ("Spiritual Meaning, 10-11) is uncomfortable with both allegory and typology as terms. Allegory brings with it the false etymological baggage that separates it from the letter of the text and typology is too limiting a category that does not deal with spiritual explanations. De Lubac prefers the simple term "spiritual understanding" or "spiritual meaning" as getting to the heart of the Christian concerns associated with both allegory and typology.
} 
Having observed the organic relationship between the figural sense and the literal sense of Scripture coupled with a positive appraisal of allegorical reading, or typology, that takes seriously the coherence of the text itself, our attention turns towards defining "plain sense" as it will be employed in the following project.

\section{3.d Towards a Theological Definition of the Plain Sense}

Our attention now turns towards a positive definition of plain sense. Put in other terms, what does an appeal to plain sense adjudicate in theologically exegetical discussions of Paul and the OT. First of all, an appeal to the plain sense of the text is not an appeal to the ostensive referent of the text or a historicality behind the text. Not only is the plain sense of Scripture not coterminous with ostensive referent in the history of Christian exegesis in the pre-modern period, it is also demonstrated in the appeals to plain sense in ancient Jewish exegesis. ${ }^{79}$ For example, and as has been observed in the preceding chapters, Isaiah's message for Paul is not strictly a message about geographical exile and return. The subject matter of the text, in a theological framework, is taking place on a different plain of inquiry than questions about ostensive referent. Again, it should be emphasized that this does not negate the historical reality of the material itself but the meaning of the text is not to be identified with that historical reality. ${ }^{80}$

Second, a plain sense reading takes seriously the form of the text itself or its internal logic and narrative structure. In other words, meaning is not found independently of the text itself. ${ }^{81}$ Though the meaning of the text may not be identified with the author's intention per se, the text itself is indispensable in

\footnotetext{
${ }^{79}$ Again, see Loewe, "The Plain Meaning of Scripture;" and Neil MacDonald, "Illocutionary Stance."

${ }^{80}$ Again, see Neil MacDonald, "Illocutionary Stance." On this score Webster interacts thoroughly with Barth's reading of Calvin's exegesis of Scripture (Webster, "Reading the Bible: The Example of Barth and Bonhoeffer," in Word and Church, 93). The issues emphasized overlap quite significantly with that of Paul's reading (e.g. the family resemblance to later exegesis). Webster states, "God we might say, is not only textual content but also primary agent of the text's realization before us. This is why a 'purely historical understanding of the mind of Scripture would be for Calvin not understanding at all. The mind of Scripture cannot be merely the object of exposition but has to be its subject as well.' The reading of Holy Scripture is thus a field of divine activity; it is not simply the handling of a textual object" (93). Barth, on Calvin states, "Exegesis has to be a conversation in which one speaks and the other listens. Listening.... is the task of the exegete" (Barth, The Theology of John Calvin, 389).

${ }^{81}$ George Hunsinger, Disruptive Grace: Studies in the Theology of Karl Barth (Grand Rapids: Eerdmans, 2000), $214 \mathrm{n} .6$. The textual mediation of God's revelation is at the heart of Calvin's concern for the sensus literalis. Truth is not to be found in vain speculations but in the text itself. Where the text remains ambiguous our doctrinal positions should remain in a penultimate position. Burnett, "John Calvin and the Sensus Literalis," 12.
} 
theological inquiry. We are reminded of the debate between the Antiochenes and the Alexandrians on this score. Where the Alexandrians tended to destroy the narrative coherence or internal logic of the text, the Antiochenes took seriously the text's akoloutheia, the way the words go, and the text's historia, the narrative coherence, as the framework for higher theological reading, theoria. One can observe this even in Paul's most direct application of allegorical readings in Gal 4:21-31. Though Paul is obviously going beyond what the text meant to its original hearers and authors, Paul is using the actual story of the text itself as presented in its narrative coherence as a witness to something beyond itself. This is a key example of the breakdown between a strict differentiation between allegory and typology. In short, a plain sense reading, as demonstrated by Paul, is a faithful reading of the text itself as witness in God's divine economy that has come to its fullest expression in his actions in Jesus Christ. The text's own witness has the ability, in this context, to speak over against the community and is not simply a construct of the community itself. ${ }^{82}$ Plain sense reading observes the distance between Scripture as authority/canon and the ecclesial community as recipient of its message. ${ }^{83}$

With this said, it follows to emphasize that, thirdly, in plain sense reading the sign of the text (sigum) is not dichotomized from its subject matter (res). ${ }^{84}$ The text in Paul's world, and subsequent Christian tradition, is the viva vox Dei and it continues to speak by divine agency to the present eschatological situation. ${ }^{85}$ As Kathryn Greene-McCreight suggests, the literal sense, in this light, can be conceived of as an "eschatological sense." ${ }^{86}$ The text of Scripture is taken seriously as the vehicle of communication pointing beyond itself to the realities of God in Jesus Christ in the

\footnotetext{
${ }^{82}$ Greene-McCreight, Ad Litteram, 20.

${ }^{83} \mathrm{John}$ Webster, speaking of the role of the canon in the divine economy, says that that the decision of the church to respect the canon "has noetic but not ontological force, acknowledging what Scripture is but not making it so" (John Webster, "The Dogmatic Location of the Canon," in Word and Church, 39). It follows to emphasize that an attendance to the witness of the text as canon is a confessional stance, similar to Paul's, that the Scriptures are the vive vox Dei and as such are authoritative. Webster states, "As Word, God is not absent or mute but present and communicative, not as it were waiting to be 'made sense of' by our cognitive or interpretive activities, but accomplishing in us the knowledge of himself" (Church and Word, 64). It should be emphasized that such a reading of Scripture is a reading that takes place in the sphere of the divine economy, that is, the church.

${ }^{84} \mathrm{On}$ the signum/res distinction see Eberhard Jüngel, God's Being is in Becoming: The Trinitarian Being of God in the Theology of Karl Barth (transl. J. Webster; Edinburgh: T\&T Clark, 2001), $19 \mathrm{n}$. 23.

${ }^{85}$ See J. Ross Wagner, "The Heralds of Isaiah and the Mission of Paul," in Jesus and the Suffering Servant, 209. Wilk ("Paulus als Interpret," 286) states, "Hosea und Jesaja präsentiert er [Paul] als Sprecher von Worten, die in seinem Sinne unmittelbar Gottes Handeln in Christus betreffen."

${ }^{86}$ Greene-McCreight, Ad Litteram, 14-15.
} 
eschatological now. Thus, to read the OT christianly is not to impose an alien meaning on the text but to take the text seriously in light of its true subject matter. ${ }^{87}$ T.F. Torrance reminds the Christian reader of the indissoluble link between biblical revelation and the larger framework of God's reconciliation of sinners in the following: "The Word of God comes to us in the Bible and can be heard as such only within our experience of God's saving activity in the Lord Jesus Christ. He has come to redeem the very humanity to which he addresses himself. Therefore the act of his revelation is inseperable from his act of reconciliation..."88 This is especially observed in Paul's reading of Isaiah in 2 Cor 5:14-6:10. The Scriptures, as the Word of God, are eschatologically linked with the subject matter of God's reconciling activity of the cosmos through his divine agent Jesus Christ and are heard correctly when listened to in that particular salvific context.

Fourthly, the literal sense and the figural sense of Scripture are not at odds with one another in a plain sense reading but are fitted together in an organic relationship of natural extension. This is to say that figurative reading is not nonliteral reading. ${ }^{89}$ Again, if the true subject matter of Scripture is God's Trinitarian action as expressly demonstrated in Jesus Christ, then to read the OT as a prefiguration of God's activity in Christ is a reading that is listening to the plain sense of the text in God's providential ordering of his revelation. ${ }^{90}$ This reading also protects the integrity of the OT as Christian Scripture recognizing its ability to continue to speak beyond the ways in which the NT receives it. It should be remembered that Paul's reading of the OT was his reading of Holy Scripture. No NT canon had been received. ${ }^{91}$ And for Paul, the Scriptures of Israel pre-figure and speak of God's activity in Jesus Christ, the gospel (I Cor 15:3).

\footnotetext{
${ }^{87}$ This is indeed the case in the early church as there only Scripture was what is today referred to as the OT. See Von Campenhausen, The Formation of the Christian Bible; and Joseph T. Lienhard, "Origen and the Crisis of the Old Testament in the Early Church."

${ }^{88}$ Thomas F. Torrance, Divine Meaning: Studies in Patristic Hermeneutics (Edinburgh: T\&T Clark, 1995), 9. See also Webster, Word and Church, 79.

${ }_{90}^{89}$ Dawson, Christian Figural Reading, 15.

${ }^{90}$ Reference needs to be made again to the pressure of the two-testament canon itself in reading the God of the whole Scriptures as Trinity. Again, see Rowe's persuasive argument on this score in his "Trinitarian Hermeneutics."

${ }^{91}$ This historical situation helps explain the rise of an appeal to a rule of faith in early church reading before the stabilization of the NT canon. See Paul M. Blowers, "The Regula Fidei and the Narrative Character of Early Christian Faith," in Pro Ecclesia VI (1997):
} 


\section{Conclusion}

The present work has argued that the final form of Isaiah's witness in chapters 40-66 have informed Paul's understanding of the message and significance of God's action in Christ and Paul's understanding of his own placement in that realized eschatological event, namely, Jesus fills the unique identity of the Servant and Paul's eschatological role is that of servant of the Servant. In this final chapter, it argued that Paul's eschatological and christological reading of the OT bears a family resemblance to Christian plain sense reading, a reading that does not divorce the literal sense from its figural capacity. ${ }^{92}$ Our study also attests to the sui generis character of Paul's reading of Scripture, and as such, is a reality with which the modern reader must squarely face. To state that Paul is attempting a midrashic exegesis or a pesher style exegesis is to fall prey to tautology, for all Jewish reading attempted to make relevant the sacred text. Such a comparison is formal and does not take into account the substantial differences between Paul and his contemporaries. This substantial differentiation is theological and this reality needs to be addressed if one is to deal faithfully with Paul's reading of the OT. ${ }^{93}$

One can observe the difficulties of attending to a subject such as this because of the interrelatedness of each of the questions. This project, therefore, is a first step approach to a theological understanding of Paul's reading of the OT and its significance for later Christian reading of the OT and biblical theology. This chapter has sought to eliminate what are thought to be bad instincts, placing the discussion in the realm of Christian theology as opposed to a history of religions approach. Not every question has been answered nor was this the intention. The emphasis rests on the theological integrity of Paul's OT reading and its sui generis character. It is in this realm of theological discourse that Paul's OT reading may prove most fruitful for Christian preaching, theology, and reading of a two-testament canon.

\footnotetext{
${ }^{92}$ It is precisely at this point that the categories offered by David Yeago ("Nicene Dogma"), concepts and judgments, help us in moving beyond the impasse of historical-critical reasoning and theological judgments. Is there a category within the history of interpretation that is a helpful judgment of Paul's conceptual activity of theologically reading the OT? This disseration has adopted the judgment of "plain sense," though this term is being used conterminously with a "theological sense."

${ }^{93}$ On taking the subject matter of Paul's writings as a priority over a psychologizing approach to Paul himself or an overly historicist approach to Paul's historical setting, see Richard Burnett's, Karl Barth's Theological Exegesis.
} 


\section{ANNOTATED BIBLIOGRAPHY}

\section{Texts and Translations}

Biblia Hebraice Stuttgartensia. Edited by K. Elliger and W. Rudolph. New edn. Stuttgart: Deutsche Bibelgesellschaft, 1977.

The Dead Sea Scrolls Translated: The Qumran Texts in English. Edited and Translated by Florentino Garcia Martinez. Grand Rapids: Eerdmans, 1996.

The Isaiah Targum: Introduction, Translation, Appartus and Notes. B. D. Chilton. Edinburgh: T\&T Clark, 1987.

Novum Testamentum Graece. Edited by E. Nestle et al. $27^{\text {th }}$ end. Stuttgart: Deutche Bibelstiftung, 1998.

The Old Testament Pseudepigrapha. Edited by J. H. Charlesworth, 2 Vols. Garden City: Doubleday, 1983-1985.

Septuaginta: Id est Vetus Testamentum graece iuxta LXX interpretes. Edited by A. Rahlfs. 2 vols. in 1. Stuttgart: Deutsche Bibelgesellschaft, 1935.

\section{Isaiah / Prophetic Literature}

Ackroyd, Peter R. Exile and Restoraton. London: SCM Press, 1968.

."Isaiah 36-39: Structure and Function." In This Place is Too Small For Us: The Israelite Prophets in Recent Scholarship. Edited by Robert P. Gordon. Winona Lake: Eisenbrauns, 1995.

Anderson, Bernhard W. "Exodus Typology in Second Isaiah." Pages 177-195 in Israel's Prophetic Heritage. Edited by Anderson and Harrelson. London: SCM Press, 1962.

. From Creation to New Creation. Minneapolis: Fortress Press, 1994.

Bailey, Daniel P. "Concepts of Stellvertretung in the Interpretation of Isaiah 53." In Jesus and the Suffering Servant: Isaiah 53 and Christian Origins. Edited by W. H. Bellinger Jr., and W. R. Farmer. Harrisburg: Trinity Press International, 1998.

Barie, Michael L., S.S., "Textual and Rhetorical-Critical Observations on the Last Servant Song (Isaiah 52:13-53:12)." In CBQ 62 (2000), 1-27.

Barton, John. "Ethics in Isaiah of Jerusalem." In This Place is Too Small For Us: The Israelite Prophets in Recent Scholarship. Edited by Robert P. Gordon. Winona Lake: Eisenbrauns, 1995. 
Baltzer, Klaus. Deutero-Isaiah. Hermenia. Minneapolis: Fortress Press, 2001.

Betz, Otto. "Jesus and Isaiah 53." In Jesus and the Suffering Servant: Isaiah 53 and Christian Origins. Edited by W. H. Bellinger Jr., and W. R. Farmer. Harrisburg: Trinity Press International, 1998.

Beuken, W. A. M. "An Example of the Isaianic Legacy of Trito-Isaiah," in Tradition and Re-Interpretation in Jewish and Early Christian Literature: Essays in Honor of Jurgen C. H. Lebram. Edited by J. W. van Henton et al. Leiden: Brill, 1986.

. "Isaiah Chapters LXV-LXVI: Trito-Isaiah and the Closure of the Book of Isaiah." In Tradition and Re-Interpretation in Jewish and Early Christian Literature: Essays in Honor of Jurgen C.H. Lebram. Edited by J. W. van Henton. Leiden: Brill, 1986, 204-221.

. "MISPAT. The First Servant Song in Its Context." In VT 22 (1972), 1-30.

. "The Main Theme of Trito-Isaiah "The Servants of Yahweh'." JSOT 47 (1990) 67-87.

. "Servant and Herald of Good Tidings: Isaiah 61 as an Interpretation of Isaiah 4055." In Le Livre D'Isaïe: Les Oracles et Leurs Relectures Unité et Complexité de L'Oubrage. Edited by Jacques Vermeylen. Leuven: Leuven University Press, 1989, 411-440.

Biddle, Mark E. “Lady Zion's Alter Ego: Isaiah 47:15 and 57:6-14 as Structural Counterparts." In New Visions of Isaiah. JSOTS 214. Edited by R. Melugin and M. Sweeney. Sheffield: Sheffield Academic Press, 124-139.

Blenkinsopp, Joseph. "The 'Servant of the Lord' in Third Isaiah: Profile of a Pietistic Group in the Persian Epoch." In This Place is Too Small For Us: The Israelite Prophets in Recent Scholarship. Edited by Robert P. Gordon. Winona Lake: Eisenbrauns, 1995.

Brown, William P. Ethos of the Cosmos. Grand Rapids: Eerdmans, 1999.

Brueggemann, Walter, The Prophetic Imagination. Minneapolis: Fortress Press, 1978.

Childs, Brevard S., Isaiah. Louisiville: Westminster/John Knox Press, 2001.

' The Canonical Shape of the Prophetic Literature.' In This Place is Too Small

For Us: The Israelite Prophets in Recent Scholarship. Edited by Robert P.

Gordon. Winona Lake: Eisenbrauns, 1995.

. Memory and Tradition in Israel. London: SCM, 1962.

. Myth and Reality in the Old Testament. London: SCM, 1960. 
Clements, R. E. "Isaiah 53 and the Restoration of Israel." In Jesus and the Suffering Servant: Isaiah 53 and Christian Origins. Edited by W. H. Bellinger Jr., and W. R. Farmer. Harrisburg: Trinity Press International, 1998.

. "A Light to the Nations: A Central Theme of the Book of Isaiah." In Forming Prophetic Literature: Essay on Isaiah and the Twelve in Honour of John D. W. Watts. Edited by James W. Watts and Paul R. House. JSOTSupp 235 (Sheffield: Sheffield Academic Press, 1996), 57-67.

. Old Testament Prophecy: From Oracles to Canon. Louisville: Westminster John Knox Press, 1996.

. Old Testament Theology: A Fresh Approach. London: Marshall, Morgan, \& Scott, 1978.

Clines, D. J. A. I, He, We, and They - A Literary Approach to Isaiah 53. JSOTSS 1. Sheffield: Sheffield Academic Press, 1976.

. "Language as Event." In This Place is Too Small For Us: The Israelite Prophets in Recent Scholarship. Edited by Robert P.Gordon. Winona Lake: Eisenbrauns, 1995.

Conrad, Edgar W. Reading Isaiah. Minneapolis: Fortress Press, 1991.

Davies, G. I. "The Destiny of the Nations in the Book of Isaiah." In The Book of Isaiah. BETL 81. Leuven: Leuven University Press, 1989, 93-120.

Der Leidende Gottesknecht: Jesaja 53 und seine Wirkungsgeschict. Edited by Janowski and Stuhlmacher. Tübingen: J.C.B. Mohr, 1998.

Eaton, John. Festal Drama in Deutero-Isaiah. London: SPCK, 1979.

. "Festal Drama." In This Place is Too Small For Us: The Israelite Prophets in Recent Scholarship. Edited by Robert P.Gordon. Winona Lake: Eisenbrauns, 1995.

Fisher, Robert W. "The Heralds of the Good News in Second Isaiah." In Rhetorical Criticism: Essays in Honor of James Muilenburg. Edited by J.J. Jackson and M. Kessler. Pittsburg: The Pickwick Press, 1974, 117-132.

Gelston, A. “Universalism in Second Isaiah.” In JTS 43 (1992), 377-398.

Gordon, Robert P. "The Story of Two Paradigm Shifts." In This Place is Too Small For Us: The Israelite Prophets in Recent Scholarship. Edited by Robert P. Gordon. Winona Lake: Eisenbrauns, 1995.

Gowan, Donald E. Theology of the Prophetic Books: The Death and Resurrection of Israel. Louiseville: Westminster John Knox, 1998. 
Hanson, Paul D. The Dawn of Apocalyptic. Philadelphia: Westminster John Knox, 1975 .

The People Called: The Growth of Community in the Bible. Philadelphia:

Westminster/John Knox Press, 1986.

. "The Word of the Servant of the Lord in Isaiah 40-55." In Jesus and the

Suffering Servant: Isaiah 53 and Christian Origins. Edited by W. H.

Bellinger Jr., and W. R. Farmer. Harrisburg: Trinity Press International, 1998.

Harner, P.B. "Creation Faith in Deutero-Isaiah." In VT 17 (1967), 298-306.

Hasel, Gerhard F. The Remnant: The History and Theology of the Remnant Idea from Genesis to Isaiah. Berrien Springs: Andrews University Press, 1974.

Houston, Walter. "What Did the Prophets Think They Were Doing?: Speech Act and Prophetic Discourse in the Old Testament." In This Place is Too Small For Us: The Israelite Prophets in Recent Scholarship. Edited by Robert P. Gordon. Winona Lake: Eisenbrauns, 1995.

Hugenberger, G. P. "The Servant of the Lord in the 'Servant-Songs' of Isaiah: A Second Moses Figure." In The Lord's Anointed: Interpretation of Old Testament Messianic Texts. Edited by P. E. Satterthwaite, R. S. Hess, G. J. Wenham. Grand Rapids: Baker, 1995.

Jeppesen, Knud. "From 'You, My Servant' to 'The Hand of the Lord is with My Servants'." In JSOT 1 (1990), 113-129.

Jobling. "Text and World: An Unbridgeable Gap?" In Second Temple Studies. Edited by P.D. Davies.

Johnson, Dan G. From Chaos to Restoration: An Integrative Reading of Isaiah 2427. Sheffield: Sheffield Press, 1988.

Kaminsky, Joel. "The Concept of Election and Second Isaiah: Recent Literature." In BTB 31 (2002), 135-144.

Kapelrud, Arvid S. "The Main Concern of Second Isaiah." In Vetus Testamentum 32 (1982), 50-58.

Kraŝovec, Jože. Reward, Punishment, and Forgiveness: The Thinking and Beliefs of Ancient Israel in the Light of Greek and Modern Views. Supplement to Vetus Testamentum 78. Leiden: Brill, 1999.

Leading Captivity Captive: 'The Exile' as History and Ideology. Edited by Lester L. Grabbe. JSOTSupp 278. Sheffield: Sheffield Academic Press, 1998.

Leclerc, Thomas L. Yahweh is Exalted in Justice: Solidarity and Conflict in Isaiah. Minneapolis: Fortress Press, 2001. 
Leibreich, L.J. "The Compilation of the Book of Isaiah." In JQR 46 (1955-56).

Levenson, Jon D. The Death and Resurrection of the Beloved Son: The

Transformation of Child Sacrifice in Judaism and Christianity. New Haven:

Yale University Press, 1993.

Melugin, Roy F. and Sweeney, Marvin A. New Visions of Isaiah. Sheffield:

Sheffield Academic Press, 1996.

Melugin, Roy F. "On Reading Isaiah 53 as Christian Scripture." In Jesus and the Suffering Servant: Isaiah 53 and Christian Origins. Edited by W. H. Bellinger Jr., and W. R. Farmer. Harrisburg: Trinity Press International, 1998.

. The Formation of Isaiah 40-55. BZAW 141. Berlin: Walter de Gruyter, 1976.

. "The Servant, God's Call, and the Structure of Isaiah 40-88." In SBL Seminar Papers, 1991, 21-30.

Mettinger, Tryggve N. D. A Farewell to the Servant Songs: A Critical Examination of An Exegetical Axiom. Lund: CWK Gleerup, 1983.

Milgrom, Jacob. Cult and Conscience: The Asham and the Priestly Doctrine of Repentance. SJLA 18. Leiden: Brill, 1976.

Moberly, R. Walter L. The Old Testament of the Old Testament: Patriarchal Narratives and Mosaic Yahwism. Minneapolis: Fortress Press, 1992.

Motyer, J. Alec. The Prophecy of Isaiah: An Introduction and Commentary. Downers Grove: IVP, 1993.

North, Christopher R. The Suffering Servant in Deutero-Isaiah: An Historical and Critical Study. Oxford: Oxford University Press, 1948.

O'Connel, Robert H. Concentricity and Continuity: The Literary Structure of Isaiah. Sheffield: Sheffield Press, 1994.

Oosting, Reinoud. "Returning to Zion: Isaiah 52:8 in light of Verbal Valency Patterns." In New Things: Eschatology in Old Testament Prophecy; Festschrift for Henk Leene. Edited by F. Postma, K. Spronk, and E. Talstra. Maastricht: Uitgeverij Shaker Publishing, 2002.

Orlinsky, Harry M. "The So-Called 'Servant of the Lord' and 'Suffering Servant' in Second Isaiah." In Studies on the Second Part of the Book of Isaiah. VTSup XIV. Leiden: Brill, 1977, 2-124.

Oswalt, John N. "Righteousness in Isaiah: Chapters 56-66." In Writing and Reading the Scroll of Isaiah, Volume 1. VTSupp 70. Edited by C.C. Broyles and C.A. Evans. Leiden: Brill, 1997. 
Polan, G. In the Ways of Justice Toward Salvation: A Rhetorical Analysis of Isaiah 56-59. New York: Peter Lang, 1986.

Quinn-Miscall, Peter D. Reading Isaiah: Poetry and Vision. Louisville:

Westminster/John Knox, 2001.

Rowley, H.H. The Servant of the Lord and other Essays on the Old Testament. Oxford: Blackwell's Press, 1952.

Rendtorff, Rolf. "The Composition of the Book of Isaiah." In Canon and Theology: Overtures to an Old Testament Theology. Minneapolis: Fortress Press, 1993, 146-169.

Reventlow, Henning Graf. "Basic Issues in the Interpretation of Isaiah 53." In Jesus and the Suffering Servant: Isaiah 53 and Christian Origins. Edited by W. H. Bellinger Jr., and W. R. Farmer. Harrisburg: Trinity Press International, 1998.

Rowley, H. H. The Servant of the Lord and other Essays on the Old Testament. Oxford: Basil Blackwell, 1965.

Sapp, David A. "The LXX, 1QIsa, and the MT Versions of Isaiah 53 and the Christian Doctrine of Atonement." In Jesus and the Suffering Servant: Isaiah 53 and Christian Origins. Edited by W. H. Bellinger Jr., and W. R. Farmer. Harrisburg: Trinity Press International, 1998.

Sawyer, John F. A. "Prophecy and Interpretation." In This Place is Too Small For Us: The Israelite Prophets in Recent Scholarship. Edited by Robert P. Gordon. Winona Lake: Eisenbrauns, 1995.

. The Fifth Gospel: Isaiah in the History of Christianity. Cambridge: Cambridge University Press, 1996.

Schiber, Davie. "Messianism and Messianic Prophecy in Isaiah 1-12 and 28-33." In The Lord's Anointed: Interpretation of Old Testament Messianic Texts. Edited by P. E. Satterthwaite, R. S. Hess, G. J. Wenham. Grand Rapids: Baker, 1995.

Schmid, Konrad and Steck, Odil Hannes. "Restoration Expectation in the Prophetic Tradition of the OT." In Restoration: Old Testaement, Jewish, and Christian Perspectives. Edited by James M. Scott. Leiden: Brill, 2002.

Schultz, Richard. "The King in the Book of Isaiah." In The Lord's Anointed: Interpretation of Old Testament Messianic Texts.. Edited by P. E. Satterthwaite, R. S. Hess, G. J. Wenham. Grand Rapids: Baker, 1995.

Scott, James M. Exile: Old Testament, Jewish, and Christian Concepts. JSJSupp 56 Leiden: Brill, 1997. 
Seitz, Christopher R. "How is the Prophet Isaiah Present in the Latter Half of the Book? The Logic of Chapters 40-66 within the Book of Isaiah." JBL 115 (1996) 219-240.

. Figured Out: Typology and Providence in Christian Scritpure. Louiseville: Westminster/John Knox Press, 2001.

. Isaiah 1-39. IBC. Louisville: Westminster/John Knox, 1993.

. "Reconciliation and the Plain Sense Witness of Scripture." Unpublished Paper, 2002.

. "The Divine Council: Temporal Transition and New Prophecy in the Book of Isaiah," JBL 109 (1990) 229-247.

. Word Without End: The Old Testament as Abiding Theological Witness. Grand Rapids: Eerdmans, 1998.

. " 'Your are my Servant, You are the Israel in whom I will be glorified': The Servant Songs and the Effect of Literary Context in Isaiah." In CTJ 39 (2004) 117-134.

. Zion's Final Destiny: The Development of the Book of Isaiah. Mineapolis: Fortress Press, 1991.

Sheppard, Gerald T. "The Scope of Isaiah as a Book of Jewish and Christian Scriptures." In New Visions of Isaiah. Edited by Melugin and Sweeney. Sheffield: Sheffield Academic Press, 1996.

Smart, James D. History and Theology in Second Isaiah: A Commentary on Isaiah 35, 40-66. Philadelphia: The Westminster Press, 1965.

Smith, P.A. Rhetoric and Redaction in Trito-Isaiah: The Structure of Growth and Authorship of Isaiah 56-66. VTSupp 62. Leiden: Brill, 1995.

Snaith, Norman H. "Isaiah 40-66: A Study of the Teaching of Second Isaiah and Its Consequences." In Studies on the Second Part of the Book of Isaiah. VTSup XIV. Leiden: Brill, 1977, 125-264.

Sommer, Benjamin D. A Prophet Read Scripture: Allusion in Isaiah 40-66. Stanford: Stanford University Press, 1998.

Steck, O.H. Sudien zu Tritojesaja. BZAW 203. Berlin: Walter de Gruyter, 1991.

Stuhlmueller, Carol. Creative Redemption in Deutero-Isaiah. AnBib 43. Rome: Pontifical Biblical Institute Press, 1970.

Sweeney, Marvin. "Prophetic Exegesis in Isaiah 65-66." Writing and Reading the Scroll of Isaiah, Volume 1. VTSupp 70. Edited by C.C. Broyles and C.A. Evans. Leiden: Brill, 1997, 455-474. 
Tomaino, Anthony J. "Isaiah 1.1-2.4 and 63-66, and the Composition of the Isaianic Corpus." In JSOT 57 (1993), 81-98.

Torrey, C.C. The Second Isaiah. Edinburgh: T\&T Clark, 1928.

van Winkle, D. W. "The Relationship of the Nations to Yahweh and to Israel in Isaiah xl-1v," in VT 35 (1985) 446-58.

von Rad, Gerhard. Old Testament Theology, Volume II. San Francisco: Harper and Row, 1965.

. "The Theological Problem of the Old Testament Doctrine of Creation." In The Problem of the Hexateuch and Other Essays. Edinburgh: Oliver \& Boyd, 1966, 131-143.

Vriezen, Th. C. "Essentials of the Theology of Isaiah" in Israel's Prophetic Heritage. Edited by Anderson and Harrelson. London: SCM Press, 1962.

Westermann, Claus. Isaiah 40-66. London: SCM Press, 1969.

Whybray, R. N. Thanksgiving for a Liberated Prophet: An Interpretation of Isaiah 53. JSOTSS 4. Sheffield: Sheffield Academic Press, 1978.

Wilcox, Peter and Paton-Williams, David. "The Servant Songs in Deutero-Isaiah." JSOT 42 (1988) 79-102.

Williamson, H.G.M. Variations on a Theme: King, Messiah and Servant in the Book of Isaiah. UK: Paternoster Press, 1997.

Zimmerli, Walter. The Old Testament and the World. London: SPCK, 1976.

. "Prophetic Proclamation and Reinterpretation." In Tradition and Theology in the Old Testament. Edited by D. A. Knight. London: SPCK, 1977. ???

\section{Second Corinthians}

Alletti, Jean-Noël. "God made Christ to be Sin (2 Corinthians 5:21): Reflections on a Pauline Paradox." Unpublished Paper for Redemption Summit, 2002.

Beale, G.K., "The Old Testament Background of Reconciliation in 2 Corinthians 5-7 and Its Bearing On The Literary Problem of 2 Corinthians 6:14-7:1" in NTS 35 , (1989) 550-581.

Belleville, Linda L. "Gospel and Kerygma in 2 Corinthians." In Gospel in Paul: Studies on Corinthians, Galatians and Romans for Richard N. Longenecker. Edited by L. A. Jarvis and P. Richardson. JSNTS 108. Sheffield: Sheffield Academic Press, 1994. 
Bieringer, R. and Lambrecht, J. Studies on 2 Corinthians. Leuven: Leuven University Press, 1994.

Boers, Hendrikus. "2 Corinthians 5:14-6:2: A Fragment of Pauline Christology." In $C B Q 64.3$ (2002), 527-547.

Bultmann, Rudolf, The Second Letter to the Corinthians. Minneapolis: Augsburg Press, 1985.

Caird, G. B. “The Theology of the Corinthian Epistles.” Int 13 (1959), 387-399.

Fitzgerald, John T. Cracks in an Earthen Vessel: An Examination of the Catalogues of Hardships in the Corinthian Correspondence. SBLDS 99. Atlanta: Scholars Press, 1988.

Furnish, Victor Paul. The Anchor Bible: II Corinthians. Garden City: Doubleday and Company, Inc, 1984.

Gaventa, Beverly, "Apostle and Church in 2 Corinthians." In Pauline Theology:

Volume Two, ed. David M. Hay. Minneapolis: Fortress Press, 1993.

Hafemann, Scott J. Paul, Moses and the History of Israel. Tübingen: J. C. B. Mohr, 1995.

. "Paul's Use of the Old Testament in 2 Corinthians." Interp 52 (1998), 246-257.

. " 'Self-Commendation' and Apostolic Legitimacy in 2 Corinthians: A Pauline Dialectic?" NTS 36, (1990), 66-88.

. Suffering and the Spirit. Tübingen: J. C. B. Mohr, 1986.

Harvey, A. E. Renewal Through Suffering: A Study of 2 Corinthians. Edinburgh: T\&T Clark, 1989.

Hay, David M. "The Shaping of Theology in 2 Corinthians: Convictions, Doubts, and Warrants." In Pauline Theology: Volume Two. Edited by David M. Hay. Minneapolis: Fortress Press, 1993.

Hofius, Otfried. "Erwägungen zur Gestalt und Herkunft des paulinischen Versöhnungsgedankens." In Paulusstudien. Tübingen: J. C. B. Mohr, 1989.

Hughes, Frank W. "Rhetorical Criticism and the Corinthian Correspondence." In The Rhetorical Analysis of Scripture. Edited by S. E. Porter and T. H. Olbricht. JSNTS 146. Sheffield: Sheffield Academic Press, 1997.

Hughes, Philip Edgcumbe. Paul's Second Epistle to the Corinthian. NICNT. London: Marshall, Morgan \& Scott, 1961. 
Interpreting 2 Corinthians 5:14-21: An Exercise in Hermeneutics. Studies in the Bible and Early Christian Interpretation 17 . Edited by J. P. Lewis. Lewiston: The Edwin Millen Press, 1989.

Käsemann, Ernst. "Die Legitimität des Apostels. Eine Untersuchung zu II Korinther 10-13." In ZNW 41 (1942), 33-71.

Kim, Seyoon. "2 Corinthians 5:11-21 and the Origin of Paul's Concept of Reconciliation." In Paul and the New Perspective: Second Thoughts on the Origins of Paul's Gospel. Grand Rapids, Eerdmans, 2002.

Kraftchick, Steven J. "Death in Us, Life in You: The Apostolic Medium." In Pauline Theology: Volume Two. Edited by David M. Hay. Minneapolis: Fortress Press, 1993.

Kurz, William, S. "2 Corinthians: Implied Readers and Canonical Implications." JSNT 62 (1996), 43-63.

Lambrecht, Jan, S.J., Sacra Pagina Series, Vol 8: Second Corinthians. Minnesota: The Liturgical Press, 1999.

. "The Favorable Time: A Study of 2 Cor 6,2a in Its Context." In Vom Urchristentum zu Jesus. Edited by H. Frankenmille and K. Kertelge. Freiburg: Herder, 1989.

Lane, William L. "Covenant: The Key to Paul's Conflict with Corinth." TyndBull 33 (1982), 3-29.

Mealand, David L. “ 'As Having Nothing and Yet Possessing Everything,' 2 Cor 6:10c." In $Z N W 67$ (1976), 277-279.

Manus, Ukachuku. "Apostolic Suffering (2 Cor 6:4-10): The Sign of Christian Existence and Identity." In AJT 1 (1987), 41-86;

Marshall, I. Howard. "The Meaning of Reconciliation." In Unity and Diversity in New Testament Theology: Essays in Honor of George E. Ladd. Edited by Robert A. Guelich. Grand Rapids: Eerdmans, 1978.

Martin, Ralph P. Word Biblical Commentary: 2 Corinthians. Waco: Word Books, 1986.

."The Opponents of Paul in 2 Corinthians: An Old Issue Revisited." In Tradition and Interpretation in the New Testament: Essays in Honor of E. Earle Ellis for His $60^{\text {th }}$ Birthday." Edited by G. F. Hawthorne and O. Betz. Grand Rapids: Eerdmans, 1987.

Martyn, J. Louis. "Epistemology at the Turn of the Ages." In Theological Issues in the Letters of Paul. Edinburgh: T\&T Clark, 1997. 
Mealand, David L. "A having nothing, and yet possessing everything [2 Kor $610 \mathrm{c}]$." In $Z N W 67$ (1976).

Murphey O'Conner, Jerome. The Theology of the Second Epistle to the Corinthians. Cambridge: Cambridge Press, 1991.

Neumann, Mathias. "Ministry, Weakness, and Spirit in II Corinthians." In Clerical 59 (1974), 647-660.

Pate, C. Marvin. Adam Christology as the Exegetical \& Theological Substructure of 2 Corinthians 4:7-5:21. Lanham: University Press of America, 1991.

Pickett, Raymond. The Cross in Corinth: The Social Significance of the Death of Jesus. JSNTS: 143. Sheffield: Sheffield Academic Press, 1997.

Plummer, Alfred, A Critical and Exegetical Commentary on the Second Epistle of St Paul to the Corinthians. ICC. Edinburgh: T\&T Clark, 1915.

Porter, Stanley E. K $\alpha \tau \alpha \lambda \lambda \alpha \alpha \sigma \sigma \omega$ in Ancient Greek Literature, with Reference to the Pauline Writings. Cordoba: Ediciones El Almendro, 1994.

Savage, Timothy B., Power Through Weakness. Cambridge: Cambridge University Press, 1986.

Scott, James M. "The Use of Scripture in 2 Corinthians 6.16c-18 and Paul's Restoration Theology." In JSNT 56 (1994), 73-79.

Stanley, David M. "The Theme of the Servant of Yahweh in Primitive Christian Soteriology, and its Transposition by St. Paul." CBQ, 16, (1954), 385-425.

Sumney, Jerry L. Identifying Paul's Opponents: The Question of Method in 2 Corinthians. JSNTS 40. Sheffield: Sheffield Academic Press, 1990.

Talbert, Charles H. Reading Corinthians: A Literary and Theological Commentary on 1 and 2 Corinthians. New York: Crossroads, 1989.

The Diakonia of the Spirit (2 Cor 4:7-7:4) Monograph Series of Benediction 10, edited by Lorenzo De Lorenzi. Rome: Benedictina Publishing, 1989.

Thiselton, Anthony C. The First Epistle to the Corinthians. NIGTC. Grand Rapids: Eerdmans, 2000.

Young, Frances and Ford, David. Meaning and Truth in 2 Corinthians. London: SPCK, 1987.

William J. Webb. Returning Home: New Covenant and Second Exodus as the Context for 2 Corinthians 6:14-7:1. JSNTS 85. Sheffield: Sheffield Academic Press, 1993. 
Wolff, Christian. "True Apostolic Knowledge of Christ: Exegetical Reflections on 2 Corinthians 5:14ff." In Paul and Jesus: Collected Essays. JSNTS 37. Sheffield: Sheffield Academic Press, 1989.

Wright, N.T. "On Becoming the Righteousness of God: 2 Corinthians 5:21." In Pauline Theology: Volume Two, ed. David M. Hay. Minneapolis: Fortress Press.

. "Reflected Glory: 2 Corinthians 3.18." In The Climax of the Covenant. Minneapolis: Fortress Press, 1993.

\section{General Pauline Literature}

Barrett, C.K. "Paul and the Introspective Conscience." In The Bible, the Reformation, and the Church: Essays in Honor of James Atkinson. JSNTS 105. Sheffield: Sheffield Academic Press, 1995.

Bartlett, David L. "Creation Waits with Eager Longing." In God Who Creates: Essays in Honor of W. Sibley Towner. Edited by W. P. Brown and S. D. McBride, Jr. Grand Rapids: Eerdmans, 2000.

Becker, Jürgen. Paul: Apostle to the Gentiles. Transl. by O. C. Denn, Jr. Louisville: Westminster/John Knox, 1993.

Bell, Richard. "Sacrifice and Christology in Paul." In JTS 53 (2002), 1-27.

Beker, J. C. Paul the Apostle: The Triumph of God in Life and Thought. Philadelphia: Fortress Press, 1980.

Black, David Alan. Paul, Apostle of Weakness: Asthenia and its Cognates in the Pauline Literature. New York: Peter Lang, 1984.

Boyarin, Daniel. A Radical Jew: Paul and the Politics of Identity. Berkeley: University of California Press, 1994.

Breytenbach, Cilliers. Versöhnung: Eine Studie zur paulinischen Soteriologie. Neukirchener Verlag, 1989.

Campbell, Douglas A., The Rhetoric of Righteousness in Romans 3.21-26. JSNTSupp. 65. Sheffield: Sheffield Academic Press, 1992.

Cerfaux, L. Christ in the Theology of St. Paul. Translated by Geoffrey Webb and Adrian Walker. New York: Herder and Herder, 1959.

Christiansen, Ellen Juhl. The Covenant in Judaism and Paul: A Study of Ritual Boundaries as Identity Markers. Leiden: Brill, 1995.

Collins, John N. Diakonia: Re-Interpreting the Ancient Sources. Oxford: Oxford University Press, 1990. 
Clements, Ronald. "A Remnant Chosen by Grace." In Pauline Studies: Essays Presented to FF Bruce. Edited by D. A. Hagner and M.J. Harris. Grand Rapids: Eerdmans, 1980.

Dabourne, Wendy. Purpose and Cause in Pauline Exegesis: Romans 1.16-4.25 and a New Approach to the Letters. Society for New Testament Studies Monograph Series 104. Cambridge: Cambridge University Press, 1999.

Das, Andrew. Paul, The Law, and the Covenant. Peabody: Hendrickson, 2001.

Nihls Alstrup Dahls, Studies in Paul: Theology for the Early Christian Mission. Minneapolis: Augsburg Press, 1997.

_. The Crucified Messiah and Other Essays. Minneapolis: Augsburg Press, 1974.

Das, A. Andrew. Paul, the Law, and the Covenant. Peabody: Hendrickson, 2001.

Dinter, Paul E. "Paul and the Prophet Isaiah." BTB 13 (1983), 48-52.

Dunn, James D. G. The Theology of Paul the Apostle. Grand Rapids: Eerdmans, 1998. . "Paul's Understanding of the Death of Jesus" in Reconciliation and Hope. Edited by Robert K. Banks. Exeter: Paternoster Press, 1974.

Dodd, Brian. Paul's Paradigmatic 'I': Personal Example as Literary Strategy. JSNTS 177. Sheffield: Sheffield Academic Press, 1999.

Dodd, C.H. According to Scripture. London: Nisbet \& Co., LTD., 1953.

Donaldson, Terence L. Paul and the Gentiles: Remapping the Apostle's Convictional World. Minneapolis: Fortress Press, 1997.

Evans, Craig A. "Paul and the Hermeneutics of 'True Prophecy'." In Biblica 65 (1984), 560-570.

Fowl, Stephen. "Learning to Narrate our Lives in Christ." In Theological Exegesis: Essays in Honor of Brevard S. Childs. Edited by Christopher Seitz an Kathryn Greene-McCreight. Grand Rapids: Eerdmans, 1999.

Hanson, Anthony Tyrrell. The Paradox of the Cross in the Thought of St.Paul. JSNTS 17. Sheffield: Sheffield Academic Press, 1987.

Harink, Douglas. Paul Among the Postliberals: Pauline Theoloyg Beyond Christendom and Modernity. Grand Rapids: Brazos Press, 2003.

Hays, Richard. "Can the Gospels Teach Us How to Read the Old Testament?" In Pro Ecclesia XI.4 (2002), 402-418. 
. "The Conversion of the Imagination: Scripture and Eschatology in

1 Corinthians." In New Testament Studies 45 (1999), 391-412.

. Echoes of Scripture in the Letters of Paul. New Haven: Yale Press, 1989.

. "The Conversion of the Imagination: Scripture and Eschatology in 1 Corinthians." NTS 45 (1999), 391-412.

. The Faith of Jesus Christ: The Narrative Substructure of Galatians 3:1-4:11, Second Edition. Grand Rapids: Eerdmans, 2002.

. The Moral Vision of the New Testament: A Contemporary Introduction to New Testament Ethics. San Francisco: HarperCollins, 1996.

. “'Who Has Believed Our Message?' Paul's Reading of Isaiah.” Paper Presented at the SBL Annual Meeting 1998. Orlando, Florida.

Hengel, Martin. The Atonement. London: SCM Press, 1981.

. The Pre-Christian Paul. London: SCM Press, 1991.

Hodgson, Robert. "Paul the Apostle and First Century Tribulation Lists." In $Z N W 74$ (1983), 59-80.

Hooker, Morna D. Jesus and the Servant. London: SPCK, 1959.

. "Beyond the Things that are Written? St. Paul's Use of Scripture." In NTS 27 1981, 307-308.

Hubbard, Moyer V. New Creation in Paul's Letters and Thought. SNTS 19. Cambridge: CUP, 2002.

Jervis, L. Ann. "Accepting Affliction: Paul's Preaching on Suffering." In Character And Scripture: Moral Formation, Community, and Biblical Interpretation. Edited by W.P. Brown. Grand Rapids: Eerdmans, 2003, 290-316.

. “'But I Want You to Know...': Paul's Midrashic Intertextual Response to the Corinthian Worshipers (I Cor 11:2-16).”In JBL 112 (1993), 231-246.

Jobes, Karen. "Jerusalem our Mother: Metalepsis and Intertextuality in Galatians 4.21-31." In WTJ 55, 1993, 299-320.

Juel, Donald. Messianic Exegesis. Philadelphia: Fortress, Press, 1988.

Justification and Variegated Nomism: Volume 1-The Complexities of Second Temple Judaism. Edited by D.A. Carson, P.T. O'Brien, and M.A. Seifrid. Grand Rapids: Baker Press, 2001. 
Käsemann, Ernst. "The Righteousness of God." In New Testament Questions of Today. Philadelphia: Fortress Press, 1967, 168-182.

Keesmat, S.C. "Exodus and the Intertextual Transformation of Tradition in Romans 8:14-30." In JSNT 54 (1994), 29-56.

Lim, Timothy H. Holy Scripture in the Qumran Commentaries and Pauline Letters. Oxford: Clarendon Press, 1997.

Litwak, Kenneth D. "Echoes of Scripture? A Critical Survey of Recent Works on Paul's Use of the Old Testament." CurBS 6 (1998), 260-288.

Luedemann, Gerd. Opposition to Paul in Jewish Christianity. Trans. by M. Eugene Boring. Minneapolis: Fortress Press, 1989.

Luz, Ulrich. Das Geschichtverständnis Des Paulus. BZEW 49. Munich: Chr. Kaiser Verlag München, 1968.

Martyn, J.L. Theological Issues in the Letters of Paul. Edinburgh: T\&T Clark, 1997.

Martin, Ralph P. Reconciliation: A Study of Paul's Theology. London: Marshall, Morgan, and Scott, 1981.

McClean, B. Hudson. The Cursed Christ: Mediterranean Expulsion Rites and Pauline Soteriology. JSNTS 126. Sheffield: Sheffield Academic Press, 1996.

Meeks, Wayne A. The First Urban Christians: The Social World of the Apostle Paul. New Haven: Yale Press, 1983.

Mell, Ulrich. Neu Schöpfung: Eine traditionsgeschictliche und exegetische Studie zu Einem soteriologischen Grundsatz paulinischer Theologie. BZNW 56. Berlin: Walter de Gruyter, 1989.

Narrative Dynamics in Paul: A Critical Assessment. Edited by B. W. Longenecker. Louisville: Westminster/John Knox, 2002.

O'Day, Gail R. "Jeremiah 9:22-23 and I Corinthians 1:26-31 A Study in Intertextuality.” In $J B L 109$ (1990), 259-267.

Paul and the Mosaic Law. Edited by James D. G. Dunn. Grand Rapids: Eerdmans, 2000.

Pauline Theology: Volume I. Edited by J. M. Bassler. Minneapolis: Fortress Press, 1994.

Pauline Theology: Volume II. Edited by D. M. Hay. Minneapolis: Fortress Press, 1993.

PaulineTheology: Volume III. Edited by D. M. Hay and E. E. Johnson. Minneapolis: Fortress Press, 1995. 
Rainer, Riesner. Paul's Early Period: Chronology, Mission Strategy, and Theology. Grand Rapids: Eerdmans, 1998.

Ridderbos, Herman. Paul: An Outline of His Theology. Grand Rapids: Eerdmans, 1996.

The Road From Damascus: The Impact of Paul's Conversion on His Life, Thought, and Ministry. Edited by R. N. Longenecker. Grand Rapids: Eerdmans, 1997.

Rosner, Brian S. Paul, Scripture, \& Ethics. Grand Rapids: Baker, 1994.

Sander, E. P. Paul and Palestinian Judaism. London: SCM, 1977.

Schlatter, Adolf. The Theology of the Apostles: The Development of New Testament Theology. Trans. by Andreas J. Köstenberger. Grand Rapids: Baker, 1998.

Schoeps, H. J. Paul: The Theology of the Apostle in the Light of Jewish Religious History. London: Lutterworth Press, 1961.

Schreiner, Thomas R. The Law and Its Fulfillment: A Pauline Theology of Law. Grand Rapids: Eerdmans, 1998.

Schütz, John Howard. Paul and the Anatomy of Apostolic Authority. Cambridge: CUP, 1975.

Scott, James M. "All Israel will be Saved.” In Restoration: Old Testaement, Jewish, and Christian Perspectives. Edited by James M. Scott. Leiden: Brill, 2002.

Schweitzer, Albert. The Mysticism of Paul the Apostle. New York: The Macmillan Company, 1956.

Seifrid, Mark A. Christ, Our Righteousness: Paul's Theology of Justification. Leicester: IVP, 2000.

. Justification by Faith: The Origin and Development of a Central Pauline Theme. NovTSup 68. Leiden: Brill, 1992.

Spencer, Aida Besancon. "The Wise Fool (and the Foolish Wise): A Study of Irony in Paul." In NT XXIII, 4 (1981), 349-360.

Stanley, C.D. Paul and the Language of Scripture: Citation Technique in the Pauline Epistles and Contemporary Literature. SNTSMS 74. Cambridge: CUP, 1992.

Stendahl, Krister. Paul among Jews and Gentiles. London: SCM, 1977.

Sumney, Jerry L. "Paul's 'Weakness': An Integral Part of His Conception of Apostleship.” In JSNT 52 (1993), 71-91.

Thielman, Frank. Paul and the Law. Downers Grove: IVP, 1994. 
. From Plight to Solution: A Jewish Framework for Understandings Paul's View of the Law in Romans and Galatians. Supplements to Novum Testamentum 61. Leiden: Brill, 1989.

Thompson, Michael. Clothed with Christ: The Example and Teaching of Jesus in Romans 12.1-15.3 JSNTSupp 59. Sheffield: Sheffield Academic Press, 1991.

Vos, Geerhardus. The Pauline Eschatology. Phillipsburg: Presbyterian and Reformed Publishers, 1994.

. "Paul's Eschatological Concept of the Spirit." In Redemptive History and Biblical Interpretation:The Shorter Writings of Geerhardus Vos. Edited by Richard Gaffin. Phillipsburg: P\&R Publishing, 1980, 91-125.

Tuckett, Christopher M. "Paul, Scripture, and Ethics: Some Observations." In New Testament Studies 46 (2000), 403-424.

Wagner, J. Ross. Heralds of the Gospel: Isaiah and Paul $<$ In Concert $>$ In the Letter to the Romans. Supplement to Novum Testamentum 101. Leiden: Brill, 2002.

. "The Heralds of Isaiah and the Mission of Paul: An Investigation of Paul's Use of Isaiah 51-55 in Romans." In Jesus and the Suffering Servant: Isaiah 53 and Christian Origins. Edited by W. H. Bellinger Jr., and W. R. Farmer. Harrisburg: Trinity Press International, 1998.

Watson, Francis. "The Triune Identity: Reflections on Pauline God-Language, in Disagreement with J.D.G. Dunn." JSNT 80 (2000), 99-124.

Wilk, Florian. Die Bedeutung des Jesajabuches für Paulus. Göttingen: Vandenhoech and Ruprecht, 1998.

__. "Paulus als Interpret der prophetischen Schriften." In Kerygma und Dogma 45 (1999), 284-306.

Wenham, David. Paul: Follower of Jesus or Founder of Christianity? Grand Rapids: Eerdmans, 1995.

Witherington III, Ben. Paul's Narrative Thought World: The Tapestry of Tragedy and Triumph. Philadelphia: Westminster/John Knox, 1994.

Wright, N. T. Climax of the Covenant. Minneapolis: Fortress Press, 1993.

. What Saint Paul Really Said: Was Paul of Tarsus the Real Founder of Christianity? Grand Rapids: Eerdmans, 1997.

Wood, John E. "Death at Work in Paul." In EvQ 54 (1982), 151-156. 


\section{General New Testament}

Achtemeier, Paul. "Omne Verbum Sonat: The New Testament and the Oral Environment of Late Western Antiqutity." JBL 109/1 (1990), 3-27.

Aune, David E. Prophecy in Early Christianity and the Ancient Mediterranean World. Grand Rapids: Eerdmans, 1983.

Barclay, John M.G. Jews in the Mediterranean Diaspora: From Alexander to Trajan [323 BCE-117 CE]. Edinburgh: T\&T Clark, 1996.

Bauckham, Richard. Jude and the Relatives of Jesus in the Early Church. Edinburgh: T\&T Clark, 1990.

. "James and the Jerusalem Church." In The Book of Acts in its Palestinian Setting. Edited by Richard Bauckham. Grand Rapids: Eerdmans, 1995, 419-480.

Beale, G.K. "The Eschatological Conception of New Testament Theology." In 'The Reader Must Understand': Eschatology in Bible and Theology. Edited by K. E. Brower and M. W. Elliott. Leicester: IVP, 1997.

Bockmuehl, Markus. Jewish Law in Gentile Churches: Halakah and the Beginnings of Christian Public Ethics. Grand Rapids: Baker Press, 2000.

Borgen, Peder. Philo, John and Paul: New Perspectives on Judaism and Early Christianity. Brown Judaic Studies 131. Atlanta: Scholars Press, 1987. . Philo of Alexandria: An Exegete For His Time. SNT 86. Leiden: Brill, 1997.

Brown, Raymond. Introduction to the New Testament. New York: Doubleday, 1996.

Bultmann, Rudolf, Theology of the New Testament: Volumes One and Two. Transl by Kendrick Grobel. London: SCM Press, 1952.

Charlesworth, James H. The Pesharim and Qumran History: Chaos or Consensus. Grand Rapids: Eerdmans, 2002.

Childs, Brevard. The New Testament as Canon. London: SCM, 1984.

Collins, John J. Diakonia: Re-interpreting the Ancient Sources. Oxford: Oxford University Press, 1990.

. The Apocalyptic Imagination: An Introduction to Jewish Apocalyptic Literature, Second Edition. Grand Rapids: Eerdmans, 1998.

Conzelmann, Hans. An Outline of the Theology of the New Testament: Second Edition. London: SCM, 1969. 
Elliott, Mark Adam. The Survivors of Israel: A Reconsideration of the Theology of Pre-Christian Judaism. Grand Rapids: Eerdmans, 2000.

Eschatology, Messianism, and the Dead Sea Scrolls. Edited by C. A. Evans and P. W. Flint. Grand Rapids: Eerdmans, 1997.

The Function of Scripture in Early Jewish and Christian Tradition. Edited by Craig A. Evans and James A. Sanders. JSNTS 154. Sheffield: Sheffield Academic Press, 1998.

The Gospel for all Christians: Rethinking the Gospel Audiences. Edited by Richard Bauckham. Grand Rapids: Eerdmans, 1998.

Hearing the New Testament: Strategies for Interpretation. Edited by J. B. Green. Grand Rapids: Eerdmans, 1995.

The Interpretation of Scripture in Early Judaism: Studies in Language and Tradition. Edited by Craig A. Evans. JSPS 33. Sheffield: Sheffield Academic Press, 2000.

Jeffers, James S. The Greco-Roman World of the New Testament Era: Exploring the Background of Early Christianity. Downers Grove: IVP, 1999.

Jesus and the Restoration of Israel: A Critical Assessment of N. T. Wright's Jesus and the Victory of God. Edited by C. C. Newman. Downers Grove: IVP, 1999.

Johnson, Luke Timothy. The Writings of the New Testament, Revised Edition.

Minneapolis: Fortress Press, 1999.

. The Real Jesus. San Francisco: HarperCollins, 1996.

Juel, Donald. Messianic Exegesis. Philadelphia: Fortress Press, 1988.

Kleinknecht, Karl Theodor. Der Leidende Gerechtfertigte. WUNT 13. Tübingen: JCB Mohr, 1984.

Ladd, George Eldon. Theology of the New Testament, Revised Edition. Grand Rapids: Eerdmans, 1999.

Lee, David. Luke's Stories of Jesus: Theological Reading of Gospel Narrative and the Legacy of Hans Frei. JSNTS 185. Sheffield: Sheffield Academic Press, 1999.

Lim, Timothy. Pesharim. Sheffield: Sheffield Academic Press, 2002.

Neill, Stephen and Wright, Tom. The Interpretation of the New Testament 1861-1986: New Edition. Oxford: Oxford Press, 1988.

Pao, David W. Acts and the Isaianic New Exodus. Grand Rapids: Eerdmans, 2000. 
Ridderbos, Herman. The Coming of the Kingdom. Philadelphia: Presbyterian and Reformed Publishers, 1962.

Vanderkam, James C. An Introduction to Early Judaism. Grand Rapids: Eerdmans, 2001.

_. The Dead Sea Scrolls Today. Grand Rapids: Eerdmans, 1994.

Watts, Rikki E. Isaiah's New Exodus in Mark. Grand Rapids: Baker, 1997.

Wright, N. T. Jesus and the Victory of God. Minneapolis: Fortress Press, 1996. . The New Testament and the People of God. Minneapolis: Fortress Press, 1993.

\section{Biblical Theology / Relationship Between the Testaments / Hermeneutics}

Auerbach, Erich. Mimesis: The Representation of Reality in Western Literature. Princeton: Princeton University Press, 2003.

Barth, Karl. Church Dogmatics, I.1. Translated by G. Bromiley. Edinburgh: T\&T Clark, 1975.

. Church Dogmatics, I.2 Translated by G.T. Thompson and H. Knight. Edinburgh: T\&T Clark, 1956.

. Church Dogmatics, IV. 1. Translated by T. F. Torrance. Edinburgh: T\&T Clark, 1961.

. Epistle to the Philippians: $40^{\text {th }}$ Anniversary Edition with Introductory Essays by Bruce L. McCormack and Francis B. Watson. Louisville: Westminster John Knox Press, 2002.

The Epistle to the Romans. Translated by E.C. Hoskyns. Oxford: Oxford University Press, 1933.

. The Theology of John Calvin. Translated by G. Bromiley. Grand Rapids: Eerdmans, 1995.

Barth, Markus. Was Christ's Death a Sacrifice? Scottish Journal of Theology Occasional Papers, 9. Edinburgh: Oliver and Boyd, 1961.

Bauckham, Richard. God Crucified: Monotheism and Christology in the New Testament. Grand Rapids: Eerdmans, 1998.

. Bible and Mission: Christian Witness in a Postmodern World. Grand Rapids:

Baker Press, 2003. 
Bavinck, Herman. Reformed Dogmatics: Prolegomena, Volume One. Translated by John Vriend. Grand Rapids: Baker Book House, 2003

Beckwith, Roger. The Old Testament Canon of the New Testament Church: and its Background in Early Judaism. London: SPCK, 1985.

Behind the Text: History and Biblical Interpretation. Scripture and Hermeneutics Series, Volume 4. Edited by C. Barthomomew, C. Stephen Evans, M. Healy, M. Rae. Grand Rapids: Zondervan Press, 2003.

Between Two Horizons: Spanning New Testament Studies and Systematic Theology. Edited by J. B. Green and M. Turner. Grand Rapids: Eerdmans, 2000.

Blomberg, Craig. "Interpreting Old Testament Prophetic Literature in Matthew: Double Fulfillment." In TrinJ 23 (2002): 17-33.

Blowers, Paul M. "The Regula Fidei and the Narrative Character of Early Christian Faith." In Pro Ecclesia VI (1997).

Bray, Gerald. Biblical Interpretation: Past \& Present. Downers Grove: IVP, 1996.

Brett, Mark G. Biblical Criticism in Crisis? The Impact of the Canonical Approach on Old Testament Studies. Cambridge: CUP, 1991.

Brewer, David Instone. Techniques and Assumptions in Jewish Exegesis before 70 CE. Tübingen: J. C. B. Mohr, 1992.

Bruns, G. L. "Midrash and Allegory: The Beginnings of Scriptural Interpretation." In The Literary Guide to the Bible. Edited by R. Alter and F. Kermode. London: Collins, 1987, 625-646.

Boyarin, Daniel. Intertextuality and the Reading of Midrash. Indianapolis: Indiana University Press, 1990.

Burnett, Richard E. Karl Barth's Theological Exegesis. WUNT II/145. Tübingen: Mohr Siebeck, 2001.

. "John Calvin and the Sensus Literalis." In SJT 57 (2004), 1-13.

Busch, Eberhard. Karl Barth: His Life from Letters and Autobiographical Texts. Grand Rapids: Eerdmans, 1994.

Calvin, John. Institutes of Christian Religion. LCC 20. Translated by F. L. Battles. Philadelphia: Westminster Press, 1960.

Caird, G. B. The Language and Imagery of the Bible. Grand Rapids: Eerdmans, 1997.

Campbell, Charles L. Preaching Jesus: New Directions for Homiletics in Hans Frei's Postliberal Theology. Grand Rapids: Eerdmans, 1997. 
Charlesworth, James H. and Weaver, Walter P. The Old and the New Testament Valley Forge: Trinity Press International, 1993.

Childs, Brevard. "Allegory and Typology within Biblical Interpretation."

Unpublished paper presented at the University of St. Andrews, 2000.

. Old Testament Theology in a Canonical Context. Philadelphia: Fortress Press, 1985.

. Biblical Theology in Crisis. Philadelphia: Westminster Press, 1970.

. Biblical Theology of the Old and New Testaments. Minneapolis: Fortress Press, 1992.

. "Midrash and the Old Testament." In Understanding the Sacred Text. Edited by J. Reumann. Valley Forge: Judson Press, 1972, 47-59.

. Myth and Reality in the Old Testament. London: SCM, 1960.

. "On Reclaiming the Bible For Christian Theology." In Reclaiming the Bible for the Church. Edited by C. E. Braaten and R. W. Jenson. Edinburgh: T\&T Clark, 1995.

. "The Sensus Literalis of Scripture: An Ancient and Modern Problem." In Beiträge Zur Alttestamentalichen Theologie: Festschrift Für Walther Zimmerli Zum 70 Geburtstag. Göttingen: Vandenhoeck and Ruprecht, 1977.

. The Struggle to Understand Isaiah as Christian Scripture: A Hermeneutical Study. Grand Rapids: Eerdmans, 2004.

Daniélou, Jean. The Lord of History: Reflections on the Inner Meaning of History. Translated by N. Abercrombie. London: Longmans, 1958.

de Lubac, Henri. Medieval Exegesis: The Four Senses of Scripture. Edinburgh: T\&T Clark, 2000.

. "Spiritual Understanding." In Theological Interpretation of Scripture: Christian and Contemporary Readings. Translated by L. O'Neill. Edited by S. Fowl. Oxford: Blackwells Press, 1997.

Disciplining Hermeneutics: Interpretation in Christian Perspective. Edited by R. Lundin. Grand Rapids: Eerdmans, 1997.

Edwards, Jonathan. Typological Writings. The Works of Jonathan Edwards, Volume 11. Edited by Harry S. Stout. New Haven: Yale University Press, 1993.

Early Christian Interpretation of the Scriptures of Israel: Investigations and Proposal. Editedy by S. Porter and J. A. Sanders. JSNTSupp 148. Sheffield: Sheffield Academic Press, 1997. 
Evans, G. R. The Language and Logic of the Bible: The Road to Reformation. Cambridge: Cambridge University Press, 1985.

Fackre, Gabriel. The Doctrine of Revelation: A Narrative Interpretation. Edinburgh Series in Constructive Theology. Edinburgh: Edinburgh University Press, 1997.

Fishbane, Michael . Biblical Interpretation in Ancient Israel. Oxford: Clarendon Press, 1985.

_.. "Interpretation of Mikra at Qumran." In Mikra: Text, Translation, Reading and Interpretation of the Hebrew Bible in Ancient Judaism and Early Christianity. Edited by M. J. Mulder, 1988, 339-378.

Fowl, Stephen. Engaging Scripture. Oxford: Blackwell, 1998.

Frei, Hans W. The Ecclipse of Biblical Narrative: A Study in Eighteenth and Nineteenth Century Hermeneutics. New Haven: Yale Press, 1974.

. "The 'Literal Reading' of Biblical Narrative in the Christian Tradition: Does it Stretch or Will it Break?' In The Bible and the Narrative Tradition. Edited by F. McConnell. New York: Oxford Press, 1986.

. Types of Christian Theology. Edited by George Hunsinger and William C. Placher. New Haven: Yale University Press, 1992.

Froehlich, Karlfried. Biblical Interpretation in the Early Church. Philadelphia: Fortress Press, 1984.

Gese, Hartmut. "The Atonement," In Essays on Biblical Theology. Minneapolis: Augsburg Press, 1981.

Ghosh, Kantik. The Wylciffite Heresy: Authority and the Interpretation of Texts. Cambridge Studies in Medieval Literature 45. Cambridge: Cambridge University Press, 2002.

Greene-McCreight, K.E. Ad Litteram: How Augustine, Calvin, and Barth Read the "Plain Sense" of Genesis 1-3. New York: Peter Lang Publishing, 1999.

Gunton, Colin. The Actuality of the Atonement.

. "Salvation." In The Cambridge Companion to Karl Barth. Edited by John Webster. Cambridge: CUP, 2002.

Hall, Christopher A. Reading Scripture with the Church Fathers. Downers Grove: IVP, 1998.

Halvini, David Weiss. Peshat and Derash: Plain and Applied Meaning in Rabbinic Exegesis. New York: Oxford Press, 1991. 
Hanson, Anthony Tyrrell. Jesus Christ in the Old Testament. London: SPCK, 1965.

Hatina, Thomas R. "Intertextuality and Historical Criticism in New Testament Studies: Is There a Relationship?” In BibInt 7 (1999), 28-43.

Helmer, Christine. "Luther's Trinitarian Hermeneutic and the Old Testament." In Modern Theology 18 (2002), 49-75.

Horbury, William. "Old Testament Interpretation in the Writings of the Church Fathers." In Mikra: Text, Translation, Reading and Interpretation of the Hebrew Bible in Ancient Judaism and Early Christianity. Edited by M. J. Mulder. Philadelphia: Fortress Press, 1988, 727-787.

Hollander, John. The Figure of Echo: A Mode of Allusion in Milton and After. Berkeley: University of California Press, 1981.

Holmgren, Fredrick C. The Old Testament and the Significance of Jesus. Grand Rapids: Eerdmans, 1999.

Hübner, Hans. "The New Testament Interpretation of the Old Testament." In Hebrew Bible / Old Testament The History of Its Interpretation: Vol. I From The Beginning to the Middle Ages Edited by M. Sæbø. Göttingen:Vandenhoeck and Ruprecht, 1996, 332-372.

Hunsinger, George, "Hans Frei as Theologian: The Quest for a Generous Orthodoxy." In Modern Theology 8 (1992), 103-128.

. Disruptive Grace: Studies in the Theology of Karl Barth. Grand Rapids:

Eerdmans, 2000.

It is Written: Scripture Citing Scripture: Essays in Honour of Barnabas Lindars. Edited by D. A. Carson and H.G.M. Williamson. Cambridge: Cambridge University Press, 1988.

Jüngel, Eberhard. God's Beings is in Becoming: The Trinitarian Being of God in the Theology of Karl Barth. Translated by John Webster. Edinburgh: T\&T Clark, 2001 .

Justin Martyr. Justin Martyr in Dialogue with Trypho: Translation, Introduction, and Notes. London: SPCK, 1930.

Kelsey, David H. The Use of Scripture in Recent Theology. Philadelphia: Fortress Press, 1975.

_. "Biblical Narrative and Theological Anthropology." In Scriptural Authority and Narrative Interpretation. Edited by G. Greene. Philadelphia: Fortress Press, 1987.

Koch, D.A. Die Schrift als Zeuge des Evangeliums: Untersuchungen zur Verwendung 
und zum Verständnis der Schrift bei Paulus. BHT 69. Tübingen: Mohr Siebeck, 1986.

Kugel, James L. and Greer, Rowan R. Early Biblical Interpretation. Philadelphia:

Westminster Press, 1986.

Lampe G.W.H. and Woolcombe, K.J. Essays on Typology. Studies in Biblical Theology 22. London: SCM Press, 1957.

Leinhard, J. P. "Origen and the Crisis of the Old Testament in the Early Church." In Pro Ecclesia IX (2000), 355-366.

Levinson, Jon D. "Historical Criticism and the Fate of the Enlightenment Project." In The Hebrew Bible, the Old Testament, and Historical Criticism. Louisville: Westminster/John Knox, 1993.

. The Death and Resurrection of the Beloved Son. New Haven: Yale University Press, 1993.

Lewis, Alan E. Between Cross and Resurrection: A Theology of Holy Saturday. Grand Rapids: Eerdmans, 2001.

Loewe, Ralph. “The 'Plain' Meaning of Scripture in Early Jewish Exegesis.” In Papers for the Institute of Jewish Studies London: Volume 1. Edited by J.G. Weiss. Jerusalem: Magnes Press, 1964, 140-185.

Louth, Andrews. Discerning the Mystery: An Essay on the Nature of Theology. Oxford: Clarendon Press, 1983.

Ludlow, Mowenna. "Theology and Allegory: Origen and Gregory of Nyssa on the Unity and Diversity of Scritpure." In ISJT 4 (2002), 45-66.

Longenecker, Richard N. Biblical Exegesis in the Apostolic Period, Second Edition. Grand Rapids: Eerdmans, 1999.

Lynonnet, Stanislas and Sabourin, Leupold. Sin, Redemption, and Sacrifice: $A$ Biblical and Patristic Study. Analectica Biblica 48. Rome: E Pontifico Instituto Biblico, 1970.

Lyttelton, A. "The Atonement." In Lux Mundi: A Series of Studies in the Religion of the Incarnation. Edited by C. Gore. London: John Murray, 1890, 275-312.

MacDonald, Neil B. Karl Barth and the Strange New World within the Bible. Carlisle: Paternoster Press, 2000.

. "Illocutionary Stance in Hans Frei's The Eclipse of Biblical Narrative." In After Pentecost: Language and Biblical Interpretation. Scripture and Hermeneutics Series II. Edited by C. Bartholomew, C. Greene, K. Möller. Grand Rapids: Zondervan, 2001, 312-328 
Marshall, Bruce. Trinity and Truth. Cambridge: Cambridge University Press, 1999.

McCormack, Bruce L. Karl Barth's Critically Realistic Dialectical Theology: Its Genesis and Development 1909-1936. Oxford: Oxford University Press, 1995.

Moberly, R. Waiter L. "The Christ of the Old and New Testament." In The Cambridge Companion to Jesus. Edited by Markus Bockmuehl. Cambridge: Cambridge University Press, 2001.

. The Bible, Theology, and Faith: A Study of Abraham and Jesus. Cambridge: Cambridge University Press, 2000.

Morgan, Robert. "The New Testament Canon of Scripture and Christian Identity". In Die Einheit der Schrift und die Vielfalt des Kanons. BZNW 118. Edited by John Barton and Michael Wolter. Berlin: Walter de Gruyter, 2003, 152-193.

Motyer, Steve. “Two Testaments, One Biblical Theology." In Between Two Horizons. Edited by J. B. Green and M. W. Turner. Grand Rapids: Eerdmans, 2000.

Noble, Paul R. "The Sensus Literalis: Jowett, Childs, and Barr." JTS 44 (1993), 1-23. . The Canonical Approach: A Critical Reconstruction of the Hermeneutics of Brevard S. Childs. BIS 16. Leiden: Brill, 1995.

A Pathway into the Holy Scripture. Edited by P. E. Satterthwaite and D. F. Wright. Grand Rapids: Eerdmans, 1994.

Preus, James Samuel. From Shadow to Promise: Old Testament Interpretation from Augustine to the Young Luther. Cambridge: Harvard University Press, 1969.

The Promise of Hermeneutics. Edited by R. Lundin, C. Walhout, A. C. Thisleton. Grand Rapids: Eerdmans, 1999.

O'Keefe, John J. “ 'A Letter that Killeth': Toward a Reassessment of Antiochene Exegesis, or Diodore, Theodore, and Theodoret on the Psalms." In JECS 8 (2000), 83-104.

Origen. Origen on First Principles. Translated by G. W. Butterworth. London: SPCK, 1936.

Plantinga, Alvin. Warranted Christian Belief. Oxford: Oxford University Press, 2000.

Radner, Ephraim. Hope Among the Fragments: The Broken Church and Its Engagement of Scripture. Grand Rapids: Brazos Press, 2004.

Reventlow, Henning Graf. Problems of Biblical Theology in the Twentieth Century. London: SCM, 1986.

. The Authority of the Bible and the Rise of the Modern World. Translated by John Bowden. London: SCM Press, 1984. 
Ridderbos, Herman N. When the Time Had Fully Come: Studies in New Testament Theology. Grand Rapids: Eerdmans, 1957.

The Right Doctrine from the Wrong Texts: Essays on the Use of the Old

Testament in the New. Edited by G. K. Beale. Grand Rapids: Baker, 1994.

Rowe, C. Kavin. "Luke and the Trinity: An Essay in Ecclesial Biblical Theology." In SJT 56 (2003): 1-26.

. "Biblical Pressure and Trinitarian Hermeneutics." In Pro Ecclesia XI (2002), 295-312.

. "Romans 10:13: What is the Name of the Lord?" In HBT 22 (2000), 135-173.

Scalise, Charles. "The 'Sensus Literalis': A Hermeneutical Key to Biblical Exegesis." SJT 42 (1989), 45-65.

Scripture and Truth. Edited by D. A. Carson and J. D. Woodbridge. Grand Rapids: Baker, 1992.

Seitz, Christopher. Figured Out. John Knox Press, 2001.

. "Christological Interpretation of Texts and Trinitarian Claims To Truth: An

Engagement with Francis Watson's Text and Truth. SJT (1998), 209-226.

Simonetti, Manlio. Biblical Interpretation in the Early Church: An Historical Introduction to Patristic Exegesis. Edinburgh: T\&T Clark, 1984.

Sin, Redemption, and Sacrifice: A Biblical and Patristic Study. Edited by S. Lyonnet and L. Sabourin.

Smail, Thomas. Once and For All. London: Darton, Longman, and Todd, 1998.

Smalley, Beryl. The Study of the Bible in the Middle Ages, Third Edition. Oxford: Blackwell's Press, 1983.

Soulen R. Kendall. "The Believer and the Historian: Theological Interpretation and Historical Investigation.” In Interp 57 (2003), 174-186.

Steinmetz, David C. "the Superiroty of Pre-Critical Exegesis." In The Theological Interpretation of Scripture: Classic and Contemporary Readings. Edited by S. Fowl. Oxford: Blackwell's Press, 1997, 26-38.

Stroup, George W. The Promise of Narrative Theology: Recovering the Gospel in the Church. Atlanta: John Knox Press, 1981.

Stuhlmacher, Peter. How To Do Biblical Theology. Allison Park: Pickwick Publications, 1995. 
. Reconciliation, Law, \& Righteousness: Essays in Biblical Theology. Philadelphia: Fortress Press, 1986.

Thisleton, Anthony C. New Horizons in Hermeneutics: The Theory and Practice of Transforming Biblical Reading. Grand Rapids: Zondervan, 1992.

Torrance, Thomas F. Divine Meaning: Studies in Patristic Hermeneutics. Edinburgh: T\&T Clark, 1995.

Treier, Daniel J. "The Superiority of Pre-Critical Exegesis? Sic et Non." In TrinJ 24 (2003), 77-103.

Vanhoozer, Kevin J. Is There a Meaning in This Text? The Bible, The Reader, and the Morality of Literary Knowledge. Grand Rapids: Zondervan, 1998.

. "The Spirit of Understanding: Special Revelation and General Hermeneutics." In Disciplining Hermeneutics: Interpretation in Christian Perspective. Edited by R. Lundin. Grand Rapids: Eerdmans, 1997, 131-165.

. "The Voice and the Actor: A Dramatic Proposal about the Ministry and Minstrelsy of Theology." In Evangelical Futures: A Conversation on Theological Method. Edited by J.G. Stackhouse, Jr. Grand Rapids: Baker, 2000 .

Volf, Miroslav. Exclusion and Embrace: A Theological Exloration of Identity, Otherness, and Reconciliation. Nashville: Abingdon Press, 1996.

von Campenhausen, Hans. The Formation of the Christian Bible. Trans. by J. A. Baker. London: Adam \& Charles Black. 1972.

Ward, Timothy. Word and Supplement: Speech Acts, Biblical Texts, and the Sufficiency of Scripture. Oxford: Oxford University Press, 2002.

Watson, Francis. Text, Church and World. Edinburgh: T\&T Clark, 1994.

. Text and Truth: Redefining Biblical Theology. Grand Rapids: Eerdmans, 1997.

. "The Quest for the Real Jesus." In The Cambridge Companion to Jesus. Edited by Markus Bockmuehl. Cambridge: CUP, 2001.

Webster, John. Word and Church: Essays in Christian Dogmatics. Edinburgh: T\&T Clark, 2001.

. "Response to George Hunsinger." In Modern Theology 8 (1992), 129-132.

Williams, Rowan. "The Literal Sense of Scripture." Modern Theology 7 (1991), 12134.

Works, Telford. Living and Active: Scripture in the Economy of Salvation. Grand Rapids: Eerdmans, 2002. 
Yeago, David S. "The New Testament and the Nicene Dogma: A Contribution to the Recovery of Theological Exegesis." Pro Ecclesia 3 (1994), 152-164.

Young, Frances. Biblical Exegesis and the Formation of Christian Culture. Peabody: Hendrickson, 2002.

. "Exegetical Method and Scriptural Proof: the Bible in doctrinal debate," Studia Patristica XIX (1989), 291-304.

. Sacrifice and the Death of Christ. London: SPCK, 1975.

. "Exegetical Method and Scriptural Proof: The Bible in Doctrinal Debate." Studia Patristica XIX (1989), 291-304.

. "The Rhetorical Schools and their influence on Patristic Exegesis," in the Chadwick Festschrift, The Making of Orthodoxy (Rowan Williams, ed.; Cambridge: University Press, 1989) 182-99.

. "Typology." In Crossing the Boundaries: Essays in Biblical Interpretation in Honour of Michael D. Goulder. Edited by S. Porter, P. Joyce, D. Orton. BIS 8. Leiden: Brill, 1994, 29-48.

\section{Narrative / Narrative Identity/ Figural Reading}

Dawson, John David. Christian Figural Reading and the Fashioning of Identity. Berkeley: University of California Press, 2002.

Ford, David F. Self and Salvation: Being Transformed. Cambridge: CUP, 1999.

Frei, Hans W. The Identity of Jesus Christ. Philadelphia: Fortress Press, 1975.

Jenson, Robert. The Triune Identity: God According to the Gospel. Oregon: Wipf and Stock, 2002.

. Systematic Theology, Volume One: The Triune God. Oxford: Oxford University Press, 1997.

Polkinghorne, Donald E. Narrative Knowing and the Human Sciences. New York: State University of New York Press, 1988.

Ricoeur, Paul. Oneself as Another. Trans. by K. Blamey. Chicago: University of Chicago Press, 1992.

Sternberg, Meir. The Poetics of Biblical Narrative: Ideological Literature and the Drama of Reading. Bloomington: Indiana University Press, 1985. 
Taylor, Charles. Sources of the Self: The Making of Modern Identity. (Cambridge: Harvard University Press, 1989.

Thiemann, Ronald F. Revelation and Theology: The Gospel as Narrative Promise. Notre Dame: University of Notre Dame Press, 1985.

Vanhoozer, Kevin. "Does the Trinity Belong in a Theology of Religions? On Angling in the Rubricon and the 'Identity' of God." In First Theology: God, Scripture, and Hermeneutics. Downers Grove: IVP, 2002, 45-70. 